\title{
An international ambidexterity model to understand new venture internationalization and growth
}

\author{
Xiaoying Ji
}

Dissertation submitted to the faculty of the Virginia Polytechnic Institute and State University in partial fulfillment of the requirements for the degree of

Doctor of Philosophy

In

Business, Management

Devi R. Gnyawali

Donald E. Hatfield

Linda F. Tegarden

Stephen B. Tallman

August 26, 2011

Blacksburg, VA

Keywords: Exploitation, Exploration, Ambidexterity, International New Venture, International Entrepreneurship

Copyright 2011, Xiaoying Ji 


\title{
An international ambidexterity model to understand new venture internationalization and growth
}

\author{
Xiaoying Ji
}

\begin{abstract}
Research in the international management literature has traditionally studied internationalization processes from an exploitation perspective. This exploitation-focused argument demonstrates an incremental process of international expansion with the internationalization of mature multinational corporations (MNCs). However, the situation is different for international new ventures, which may not have sufficient resources and economies of scale in their domestic countries before starting operations in other countries. After initial internationalization at a young age, international new ventures might choose to go to similar foreign markets to leverage and exploit existing knowledge for growth or they might continue experimenting with less related foreign markets. In this study, I propose that international new ventures benefit from using an ambidextrous strategy for long-term performance employing both exploitation and exploration.

I use both traditional international management literature and international entrepreneur studies to develop the concept of international ambidexterity. I argue that new ventures are able to develop such a capability, defined as the capability to successfully balance international exploitation and exploration activities. This capability is founded on new ventures' initial activities but needs to be further developed and refined through international operations with both incremental and radical approaches. I also propose that the relationship between international ambidexterity and new venture growth is positively moderated by these firms'
\end{abstract}


subsequent activities to explore technological knowledge. In order to theoretically develop and empirically test the concept of the international ambidexterity, I introduce arguments that support certain antecedents to developing this capability.

Results from my analyses show that the benefits associated with international exploration through early internationalization are realized when a firm continues further commitment to exploitation capabilities so they can accomplish ambidexterity learning from narrower scope of international expansion. Additionally, domestic alliances and foreign alliances show significant relationships with new venture's international exploration. Therefore, inter-organizational learning can link to the social capital and network perspectives in international entrepreneurship research; mimetic learning can help investigating the social aspects of international entrepreneurship studies. Further, new ventures should be encouraged to build interorganizational networks, domestically and internationally to pursue their growth. 


\section{ACKNOWLEDGEMENT}

It is a great experience to pursue my doctoral degree. Words go beyond my ability to express my feelings during the last five years, especially my gratefulness to so many people who bless me and help me through my PhD studies. First my special thanks go to my dissertation committee: Drs. Donald E. Hatfield, Devi R. Gnyawali, Linda F. Tegarden, and Steven B. Tallman. Devi, Don, Linda and Steve were very supportive and the experiences working with them will guide me in the future when I pursue my academic career.

Dr. Don Hatfield has helped me throughout my education at Virginia Tech. He is very instrumental in my academic pursuits. He spends much time mentoring me to conduct high quality research. His knowledge in the Strategy field and persistent support over the past years has guided my studies in a very positive way. I am thankful for his intellect and insights and appreciate his involvement.

Dr. Devi Gnyawali is an excellent advisor as well. He has given me a lot of guidance to pursue rigorous academic research. I still remember the time when I took his Strategy seminar during my first semester, the time when I did not know how to achieve excellence in the $\mathrm{PhD}$ program. Working with him has given me the opportunity to learn more about conceptual thinking, and professional writing. He is indeed a very good thinker and writer.

Dr. Linda Tegarden has been my mentor and friend since my first semester in Virginia Tech. I am so grateful for all the research opportunities she has provided me. She has given me a lot of guidance and freedom to pursue my academic development. She always encouraged me with her smile when I struggled with my research ideas. Her hand-on mentoring made me enjoy this $\mathrm{PhD}$ studies. 
The honor was mine when Dr. Steve Tallman agreed to serve as a committee member for my dissertation. His helpfulness over the past year has guided my dissertation in a positive way, and gave me confidence as well. He is very knowledgeable and his advices were greatly valued and appreciated.

Besides, I want to thank Dr. Carlson for his guidance in my academic development. I am so grateful for the opportunity to work with him and got my first publication. He has inspired me to pursue exemplar research. His insightful advices and his teaching have significantly contributed to my research ability development. The effort he put in advising, encouraging and supporting students shows me a great model to follow in the future.

I appreciate that the opportunity to get known Dr. Catherine Axinn when I worked as visiting professor at Ohio University during my last year of dissertation. She is a wonderful editor and scholar! I couldn't thank her more for her support.

I am so glad that I have a wonderful group of cohorts. Here, I want to address my thankfulness to a special lady, Gretchen L. Schaupp. I couldn't imagine how my doctoral life would have been without her. She is such a wonderful friend, who cares about me so much! She is always the one cheering me up when I felt weak, the one encouraging me when I struggled, and the one celebrating with me when I made accomplishment. Friendship with her is one of the most precious things I have earned during these five years.

Last but not least, I would also like to appreciate the support from my family, especially from Qian Yu, my husband. He is the one I could never be more grateful to. He is the one who encouraged me to pursue doctoral degree and has been supporting my work during the last five years. I might have given up without his tolerance and understanding. I am so lucky to realize 
how much he loves and cares about me no matter how much trouble physical distance made for us. 


\section{TABLE OF CONTENTS}

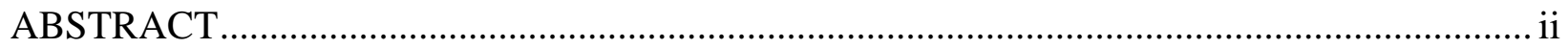

ACKNOWLEDGEMENT ........................................................................................ iv

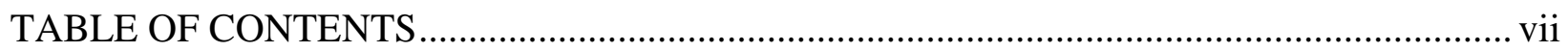

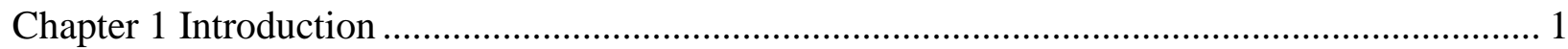

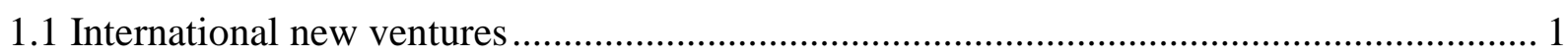

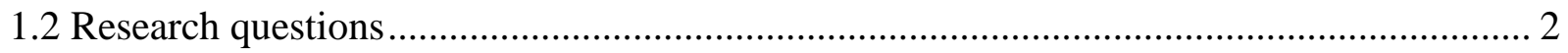

1.3 Summary of the conceptual model f.............................................................................. 5

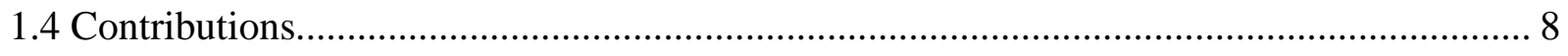

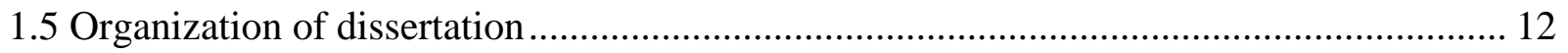

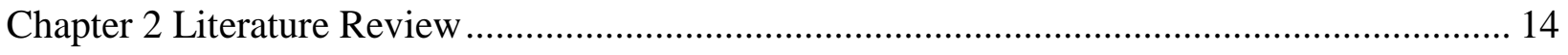

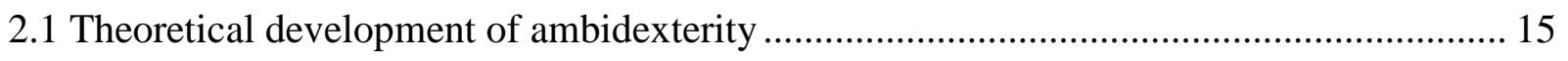

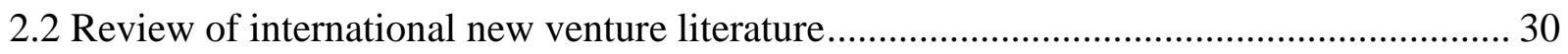

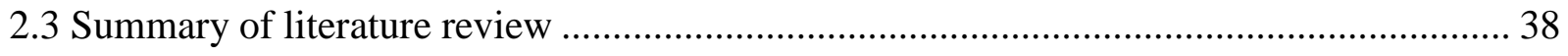

Chapter 3 Theoretical Framework and Hypotheses Development ....................................... 41

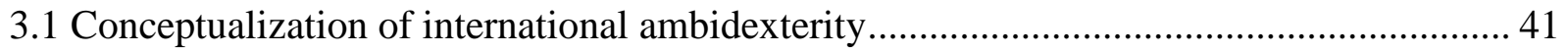

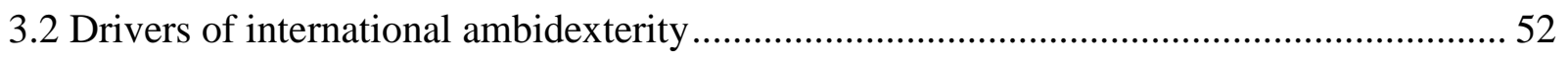

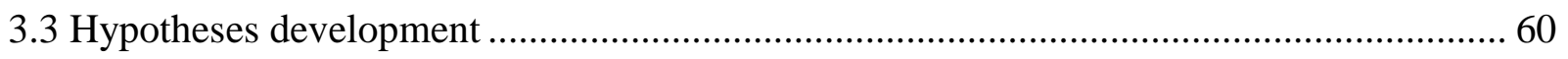

3.4 Summary regarding to conceptualization of International Ambidexterity ...................... 81

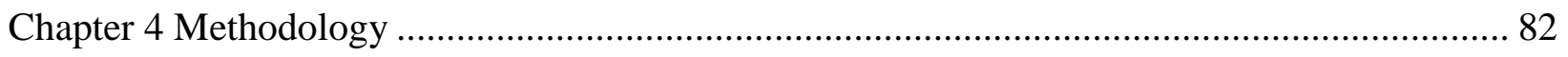

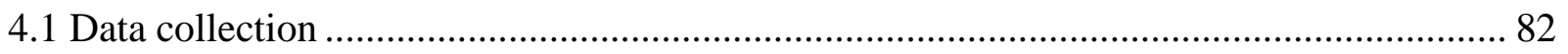

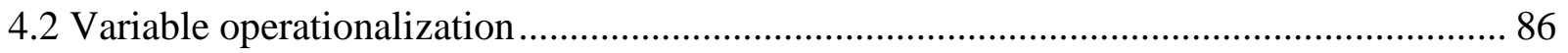

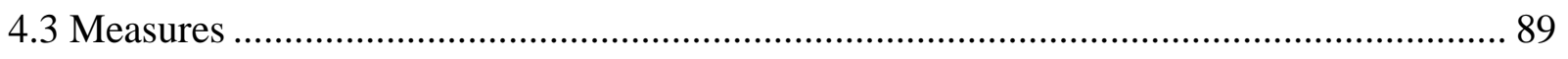

Chapter 5 Analytical Procedures and Results ................................................................... 98

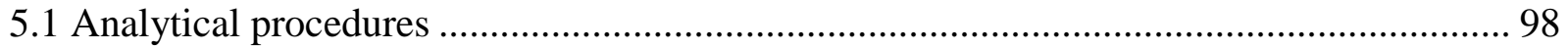

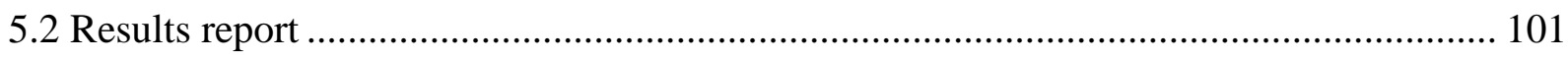

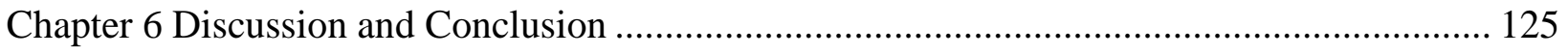

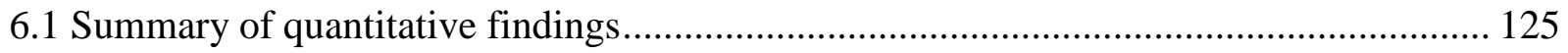

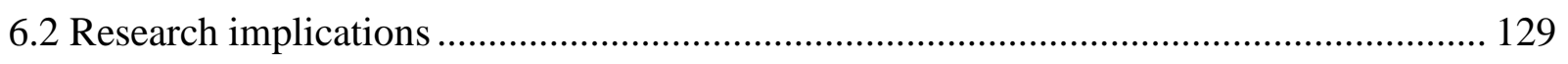

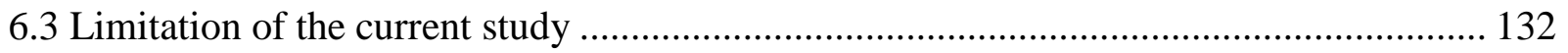

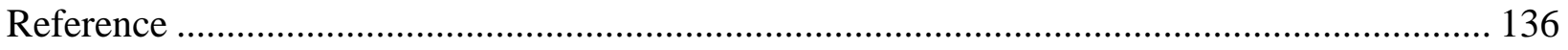




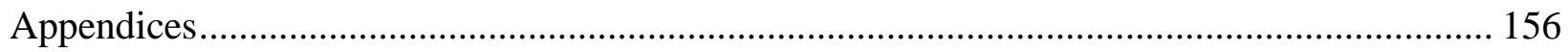

Appendix A All figures included in the dissertation ...................................................... 156

Appendix B Literature review on exploitation, exploration and ambidexterity ...................... 161

Appendix C Literature review on international new ventures (Empirical Evidence)............. 169

Appendix D Case study for conceptualization of international ambidexterity ....................... 174

\section{List of tables and figures}

Table 2 Summary of constructs, variables and measures for hypotheses testing .........................95

Table 3 Summary of statistics procedure for each hypothesis..................................................... 99

Table 4 Descriptive summary of international expansion of 311 international new ventures.... 103

Table 5 Descriptive summary of 311 international new ventures .............................................. 104

Table 6 Descriptive summary of 175 early internationalizing new ventures ............................. 106

Table 7 Descriptive summary of 175 early internationalizing new ventures .............................. 107

Table 8 Correlation of variables for 311 international new ventures ........................................ 109

Table 9 Probit analyses for technological integrated knowledge, alliance ties and geographic

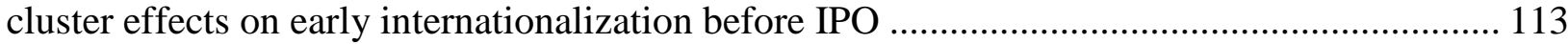

Table 10 Negative binomial analyses for technological integrated knowledge, alliance ties and geographic cluster effects on scope of pre-IPO international expansion.................................... 116

Table 11 Negative binomial regression analyses for technological integrated knowledge, alliance ties and geographic cluster effects and scope of post-IPO international expansion ................... 119

Table 12 Regression analysis for international ambidexterity and international new venture

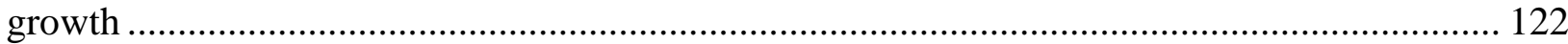

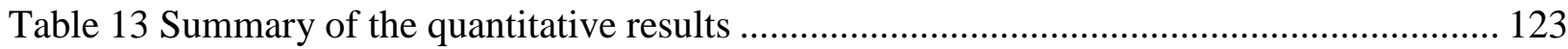

Figure 1 Conceptual model for international ambidexterity of new ventures ........................... 156

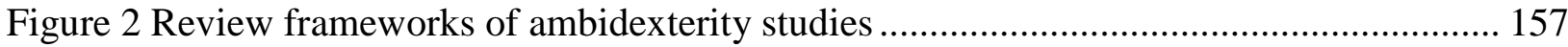

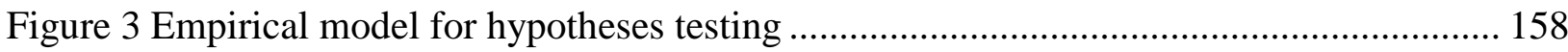

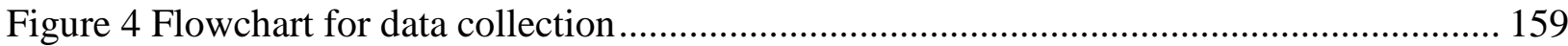

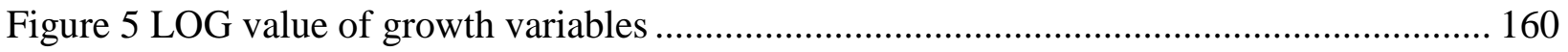




\section{Chapter 1 Introduction}

\subsection{International new ventures}

Research in the international management literature has traditionally studied the internationalization processes from an exploitation perspective. The resource-based view (Penrose, 1959; Wernerfelt, 1984; Barney, 1991) and dynamic capabilities studies (Teece, Pisano and Shuen, 1990) argue that firms enter new markets in order to exploit the core capabilities that they built in their home countries, therefore benefiting from both economies of scale and economies of scope in a global context. This exploitation-focused argument demonstrates an incremental process that is used to explain the internationalization of mature multinational corporations (MNCs) (Ghoshal \& Bartlett, 1990; Gupta \& Govindarajan, 2000; Kogut \& Zander, 1993; Kostova \& Roth, 2003; Tsai, 2002). However, the situation is different for international new ventures, which may not be able to allocate sufficient resources and build economies of scale in their domestic countries before starting operations in other countries. Though these young firms grow internationally, they do so in order to explore opportunities from host countries, and turn disadvantages, such as insufficient resources and newness liability, into sources of competitive advantages (Oviatt and McDougall, 1994). In the case of international new ventures, then, internationalization can be regarded as a search and experimentation process whereby firms explore a variety of strategies to find the one that best complements their competitive situation in the global market. Oviatt and McDougall (2005) redefined the attributes of international new ventures by integrating speed and international scopes into a combination of innovative, proactive, and risk-seeking behavior, which provide the foundation to develop the concept of international exploration to understand international new venture. 
The shortcomings of current studies on the process of internationalization tend to be that scholars focus too much on one competitive strategy or the other, thereby ignoring the duality of exploitation and exploration. By neglecting to focus on a dual strategy, firms are more likely to be subject to the risk of obsolescence when their magnitude of exploitation exceeds that of their exploration. Given this perspective, existing competencies can quickly become outdated, and further path dependency will slow down the growth process of a new venture. At the same time, when new ventures put too much emphasis on exploration for international operations, they risk failing to achieve appropriate returns from these experimental activities. Therefore, I argue that new ventures can develop the capability to successfully balance international exploitation and international exploration activities.

\subsection{Research questions}

I employ ambidexterity literature to develop a concept of international ambidexterity, defined as a balance of international exploitation and international exploration, to demonstrate the internationalization process of new ventures. The concept of ambidexterity, defined as firms' capabilities to pursue a balance of exploitation of knowledge and exploration of knowledge, has been of interest in management and social science for decades (Gupta, Smith and Shalley, 2006; March, 1991; Lavie, Stettner and Tushman, 2010). According to March (1991), exploitation is defined as activities of refining and extending existing knowledge. Exploitation occurs when an organization persists within an existing knowledge trajectory and thus leverages existing capabilities in order to create new knowledge. Exploration is defined as activities of searching and experimenting with new alternatives and entails a shift away from the current knowledge base and skills to a novel trajectory of knowledge including new technical skills, market expertise or external relationships. Both exploitation and exploration are essential in 
organizational learning (Benner and Tushman, 2002; Lavie, et al., 2010). Exploitation, or the leveraging of existing capabilities, generates short-term benefits for firms to improve the quality and efficiency in their organizational development, while exploration, or the act of searching and experimenting with new alternatives, provides opportunities for revolutionary changes and longterm performance. However, firms are often confronted with the dilemma of exploiting existing competencies while also exploring new capabilities (Vera and Crossan, 2004). Therefore, the most successful firms are often those who can resolve the tension between exploitation and exploration, by pursuing ambidexterity to achieve long term superior performance (Gibson and Birkinshaw, 2004; He and Wong, 2004; Lavie, et al., 2010). I argue that international new ventures can benefit from using an ambidextrous strategy for long-term performance. In this dissertation, the notion of international ambidexterity is clearly conceptualized to demonstrate the internationalization process of new ventures. The first issue that will be addressed in this

\section{dissertation is:}

\section{To what extent do international new ventures achieve an international}

\section{ambidexterity?}

In order to answer this research question, both traditional international management literature and international entrepreneurship studies are employed to develop the concept of the international ambidexterity. I argue that new ventures are able to develop an international ambidexterity. For example, new ventures might decide to enter into an international market to explore an international knowledge which is less consistent with the existing capabilities. Furthermore, they might also choose to introduce a product into a related domestic market to leverage and exploit existing knowledge for growth or to continue experiments with less related international markets. By extending and expanding geographically, a new venture grows in size 
and volume, develops diverse and complementary capabilities and becomes a more established entity (Gabrielsson, Kirplani, Mimitratos, Solberg \& Zucchella, 2008; Gassmann \& Keupp, 2007; Mathews \& Zander, 2007; Rialp, Rialp, \& Knight, 2005). This capability is founded on new ventures' initial activities but needs to be further developed and refined through international operations with both incremental and radical approaches. However, exploration and exploitation require fundamentally different and inconsistent structures and competencies, which often create a dilemma for new ventures (Benner and Tushman, 2003). Successful new ventures are those which can resolve the tension associated with international ambidexterity. In order to examine the contribution that international ambidexterity makes to a new ventures' success, the second question will be addressed is as follows:

Do those new ventures which achieve an international ambidexterity accelerate their growth faster than those without this capability?

In order to achieve the advantages of international ambidexterity, new ventures need to develop a dynamic capability that goes beyond creating just one competency, to the extent that the competencies of exploitation and exploration can interact with each other to create value (Jansen, Tempelaar, Vanden Bosch, \& Volberda, 2009). I propose that successful new ventures need such an ambidexterity, which is based on a match in the relative magnitude of exploratory and exploitative activities, while an imbalance between exploration and exploitation poses challenges to a new venture. In addition to a competition view between exploitation and exploration, Gupta et al. (2006) also pointed out a complementary view for ambidextrous capability. This complementary view proposes that punctuated equilibrium or temporal evolution between long term of accumulative exploitation and short bursts of exploration. Building on this notion, I argue that international new ventures may use sequential adjustments to shift between 
exploration and exploitation. For example, a new venture needs to achieve a certain level of knowledge stock before making an early internationalization decision, and further, international growth is also based on continuous exploitation of certain knowledge before pursuing an exploration of international business knowledge. More specifically, once a new venture initiates new market entries, the repeated use of existing knowledge can make managers become more aware of current local knowledge and lead them to have a deeper understanding of the opportunities available in the foreign market. In such a case, stronger exploitation through incremental entries helps new ventures to explore early internationalization benefits. In this way, early internationalization is complementary to exploitative learning by new ventures and can impact their further growth. I argue that competitive advantages will emerge for those new ventures that can identify the optimal equilibrium and balance of international exploitation and exploration. However, the development of this capability is not easy: new ventures face resourceallocation constraints, have limited absorptive capacity for learning, and have strong need to grow quickly. In response, they often make active decisions to invest in the development of international ambidextrous capabilities. Given the importance of ambidexterity to new ventures, the third question will be addressed is as follows:

\section{What factors can help new ventures develop international ambidexterity?}

\subsection{Summary of the conceptual model}

In order to theoretically develop and empirically test the concept of the international ambidexterity, I introduce several arguments that support certain drivers or antecedents to developing such a capability. Consistent with the criteria for defining international new venture proposed by Oviatt \& McDougall's (1994), these antecedents include the advantages of a firm's resource as well as the contribution of information and focus of a firm's managerial mindset. I 
propose that a new venture can develop its own structure of knowledge built upon component knowledge. This knowledge includes elements such as R\&D skills in technology-oriented industries as well as knowledge of advertising in consumer industries. Secondly, a new venture can also develop its own structure of knowledge built on integrated knowledge, which refers to a broader understanding of how the components are brought together, a knowing of who is whom and how firms are connected, and an understanding of institutional influences and the importance of local embeddedness (Tallman, Jenkins, Henry, \& Pinch, 2004). The structure of knowledge represents technological and business resource advantages, and this structure also demonstrates information availability and reflects a managerial mindset for learning. I also propose that a new venture's relational knowledge exchanges (including both domestic ties and foreign ties) can provide valuable resources, useful information, and stronger learning capabilities, which would further contribute to developing international ambidextrous capability. In addition to direct relationships, I argue that it is essential to understand geographic knowledge dynamics (including geographic clusters and competition from foreign MNCs). These relational and local factors may also interact with internal knowledge structures to enhance new venture's international ambidextrous capability.

For more details, please refer to Figure 1, which illustrates the theoretical model as the foundation for my study.

I use archival data sources for my measures. Thompson Financial Security Data Corporation (SDC) Global New Issues database provides the base sample of IPO firms. In this study, the SDC database offers detailed data on firms' IPO activities. One advantage of this approach is that it overcomes social desirability biases. For example, in my quantitative study, I first obtained all IPOs from the SDC of common shares by U.S firms between 1998 and 2008. I 
then merged this data from the SDC with other financial indicators drawn from Compustat. A longitudinal research design is important to study my hypotheses. The ventures that were corporate subsidiaries or corporate spin-offs will be eliminated from the sample, given the prerequisite that the firms must be independently founded and operated in order to meet my conceptual definition of truly being young new ventures. Using a sample of publicly held firms is beneficial given that public access to key financial information, and internationalization data, would be hard to obtain otherwise. In order to acquire growth measures, financial growth indictors are sourced from the Compustat database. Other archival data are included as well, such as data from Mergent Online's database, SEC filings and firms' official websites, which are used for capturing the information of international ambidextrous activities.

\section{Figure 1 Conceptual model for international ambidexterity of international new ventures}

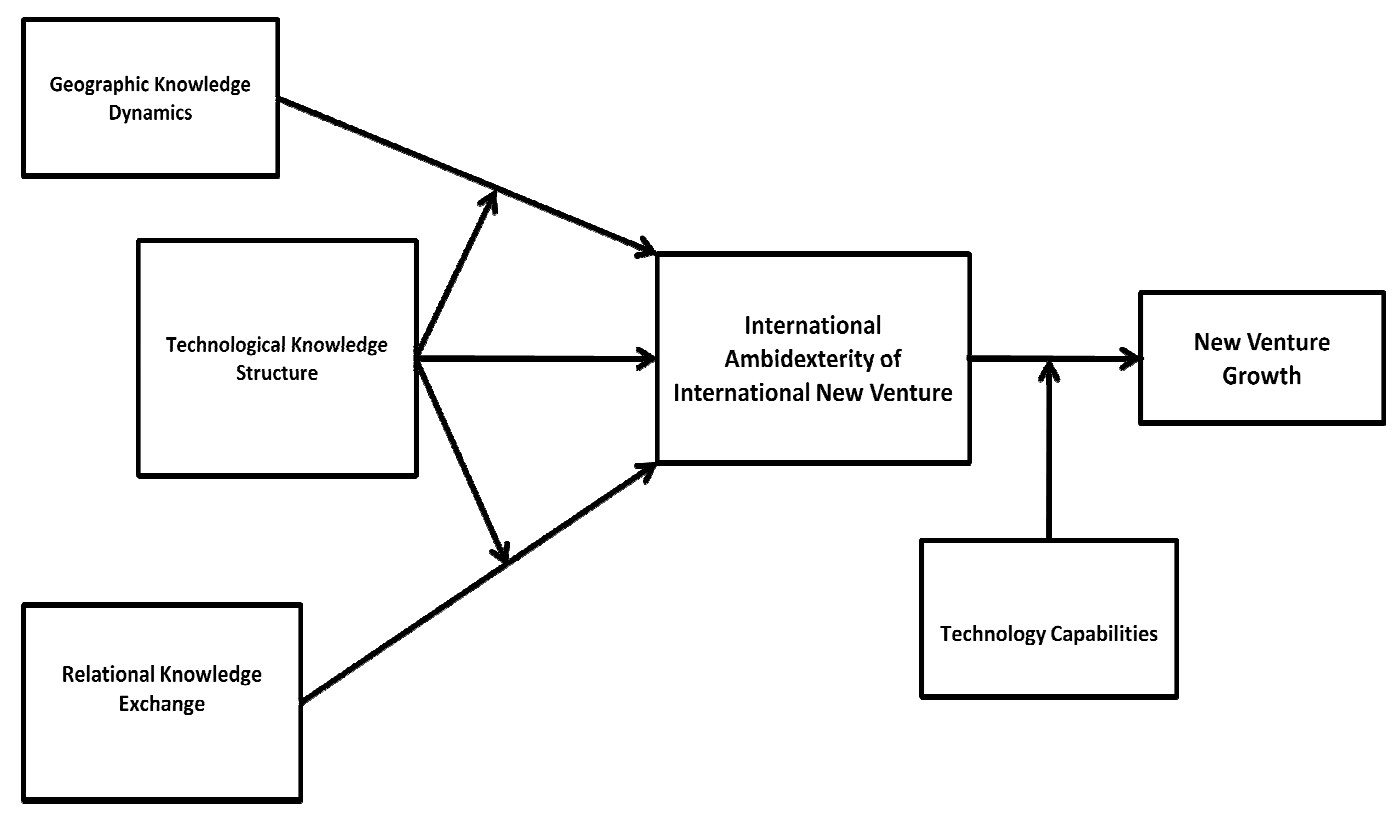




\subsection{Contributions}

This dissertation seeks to theoretically develop and empirically test the concept of the international ambidexterity, which emphasizes the relative balance of international exploitation and international exploration in supporting new ventures' growth. Through this study, the contributions of this dissertation can be summarized as follows:

First, my primary theoretical contribution lies in developing a concept of international ambidexterity to explain the internationalization of new ventures and to thus resolve conflicting views between traditional views within international management and international entrepreneurial literature. The emerging phenomenon of international new ventures has raised many interesting questions about the internationalization processes of firms, and thus challenges traditional explanations of internationalization. One of the key questions is why new ventures go abroad at the early stage when they have not developed economies of scale in their home country. In the field of entrepreneurship, new ventures have been viewed as entities primarily focused on finding and identifying opportunities (Shane and Venkataraman, 2000). As entrepreneurs, managers of new ventures may carry out new combinations of strategies, thus exploring new opportunities (Schumpeter, 1934). The international entrepreneur literature argues that new cases concerning international new ventures provide distinguished frameworks to explain internationalization as compared to traditional arguments such as incremental processes, path dependency and knowledge dissemination to demonstrate the internationalization process of large MNCs. By developing the concept of international ambidexterity, I argue that new ventures - like large MNCs - need to develop capabilities for further competitive advantage, which are centered on international entry mode selection, further gradual learning, as well as the development of a portfolio of internationalization and reverse transfers from host countries 
(Matthew and Zander, 2007; Sapienza, Autio, George, \& Zahra, 2006). Therefore, new ventures face challenges when it comes to balancing exploitation and exploration, just as mature corporations do. In comparison to the international entrepreneur literature, which overemphasizes the exploration perspective of the internationalization process, in order to explain the concept of international ambidexterity, I argue that both traditional models (Johanson and Vahlne, 1990) and international entrepreneur frameworks (Oviatt and McDougall, 1994) serve as the key sources for concepts explaining the internationalization process of new ventures. I propose the concept and develop in-depth discussions on common points and conflicting views between international new ventures models and gradual internationalization process models from the perspective of resource-based value creation. Therefore, successful new ventures are those who can build such an international ambidextrous capability to gain competitive advantages.

\section{Second, I contribute to the ambidexterity literature by providing a theoretical}

\section{framework, as well as empirical evidence, that supports the idea that internal knowledge} structures and external knowledge exchange relationships interact with each other to enhance a firm's long-term performance through the development of ambidextrous capabilities. Though the literature on new ventures' ambidexterity capabilities is not well explored, these young firms provide a context to better understand the ambidexterity development process including antecedents, outcomes and contingent factors. From the antecedent perspective, previous literature has argued that slack resources are one of the key sources for developing ambidextrous capabilities. New ventures lack specific resources, a sufficient customer base and the necessary investments in their structures. They are assumed to be more susceptible to failure because of their "liability of newness". Therefore, investments in resource allocations, capability developments and equilibrium structures are required to develop 
an ambidextrous capability. This is not saying that new ventures need to maximize both capabilities in order to achieve the optimal value. In my study, I focus on how new ventures can build technological knowledge during their initial stages and relational knowledge in order to develop an ambidextrous capability. In terms of outcomes, critics of the literature request more longitudinal studies to understand the effects of ambidexterity. In comparison to new ventures, MNCs often focus on quality improvements and efficiency outcomes for international expansion, and thereby pursue short-term performance. Growth has been identified as one of the key performance measures for entrepreneurial firms. New ventures seek business opportunities in order to achieve further growth (Shane and Venkataraman, 2000). In this study, I empirically test whether international ambidextrous capabilities positively impact new ventures' further growth. In this sense, new ventures provide a logical sample for investigating the relationship between ambidexterity and firm growth.

\section{My third contribution is to advance organizational learning as an explanation of the} internationalization process. In the existing literature (Kogut and Zander, 1993; Kostova and Roth, 2003), intra-organizational creation, exchange and dissemination of knowledge to other countries is only one aspect of firms' knowledge transfer mechanisms and it is discussed mostly with regard to MNCs. Because of the liability and limited resources that characterize new ventures, these firms are dependent on external resources and relationships for capability development. However, they may develop different patterns built on their own capabilities and external sources for internationalization. Internally, new ventures face constraints to international learning in terms of having limited capital, management, time, experience and information resources. Externally, the dynamic environment including technological, social and economic changes and the fast obsolescence of products or limited domestic demand pressures 
new ventures to undertake international exploration. Therefore, to resolve the tension between exploitation and exploration, firms must develop new capabilities, which are contingent on different factors. With the exception of a few recent papers (Fernhaber, McDougall, \& Oviatt, 2004; Mudambi \& Zahra, 2007; Yamakawa, Peng, and Deeds, 2008), previous entrepreneurship research has not explicitly considered the integrative effects from different levels of analysis to understand new venture growth, especially in an international context. Within this study, I develop a multi-level conceptual model to argue that new ventures can learn from their experiences at the initial stage of their formation. Inter-organizational learning in domestic countries can provide firms with new patterns of knowledge sources. I integrate interorganizational factors with intra-organizational capabilities to explain the creation of knowledge and argue that the interaction of both learning approaches will determine whether new ventures can successfully build international ambidextrous capabilities.

The final goal of this study is to provide some managerial insights. From a management viewpoint, this is a unified framework that indicates the need for the development of an international ambidextrous capability as a strategic investment for new venture growth. An international ambidextrous capability facilitates internationalization at the early stages of venture formation and accomplishes entrepreneurial growth in an international context while simultaneously respecting entrepreneurial dynamics in to this specific context. It is not an easy task for an organization to solve the dilemma associated with international exploitation and exploration. The manager's task is not only to identify the optimal balance for internationalization, but to also benefit from more sophisticated tools for analyzing their firm's knowledge structure and their firm's position in social networks and geographic locations, so as to be able to take advantage of internationalization. 
Furthermore, this study can also contribute to understanding about other managerial aspects of international entrepreneurs: inter-organizational learning can link to social capital and network perspectives in international entrepreneurship research; mimetic learning can help in investigating social aspects of international entrepreneurship studies.

\subsection{Organization of dissertation}

Chapter 2 reviews the literature on ambidexterity and international new ventures. I especially state my motivation focused on antecedents, capability building and outcomes of ambidexterity. I also investigate the international new ventures literature from both theoretical and empirical perspectives. Therefore, I am able to build an international ambidexterity model to explain how new venture growth can fill the gap for both literatures. And, a comprehensive international ambidexterity framework can help current theory building and development in bridging international management and entrepreneur studies.

Chapter 3 proposes a conceptual model for my dissertation, which is built upon how different antecedents can impact new venture's international ambidextrous capability and further growth through different levels of interaction. Furthermore, I develop my hypotheses based on the conceptual arguments in order to test a multi-level framework: internal knowledge structure possessed by new ventures, relational knowledge exchanges and local knowledge dynamics.

Chapter 4 provides a description of a case-based qualitative study in order to investigate the link between early internationalization and new ventures growth. In this section, I examine how resource advantages, information availability, managerial mindset, and international experiences are associated with new ventures' internationalization, which complements the theoretical arguments I develop in Chapter 3. In addition, in Chapter 4, I also describe sampling of the quantitative study, used to test an international ambidexterity for new venture growth. 
Chapter 4 also provides measures associated with the appropriate variables for two broad types of firm capabilities-exploitative and explorative capabilities and knowledge embedded in technology and international context. And the antecedents' measures will also be discussed in detail in this chapter.

Chapter 5 deals with the results of the quantitative analysis of my theoretical framework. First, I present the list of different analyses to test the drivers of international ambidexterity and the relationship between international ambidexterity and new venture growth. Then, the test results for hypotheses developed in Chapter 3 are presented. In the third section, the research findings are summarized.

Chapter 6 discusses the conclusion of the analysis. First, I summarize the findings from both the qualitative and quantitative analyses. These findings of the dissertation provide important research and managerial implications. The second section, addressing research implications, follows. Research implications of the results for the ambidexterity literature, international new ventures and international management studies are followed by a discussion of the limitations of the study. This chapter concludes with final reflections on the managerial implications of international ambidexterity for new venture growth. 


\section{Chapter 2 Literature Review}

In this study, I employ the concept of ambidexterity to explain the internationalization process of new ventures. Thus, I review key literature concerning theoretical arguments and empirical findings about ambidexterity, which is followed by a review of the extant research on international new ventures. In the following sections, I structure the current ambidexterity literature from a process perspective including antecedents to ambidexterity, its outcome and contingent factors. This structure is illustrated in Figure 2.

\section{Figure 2 Review framework of ambidexterity studies}

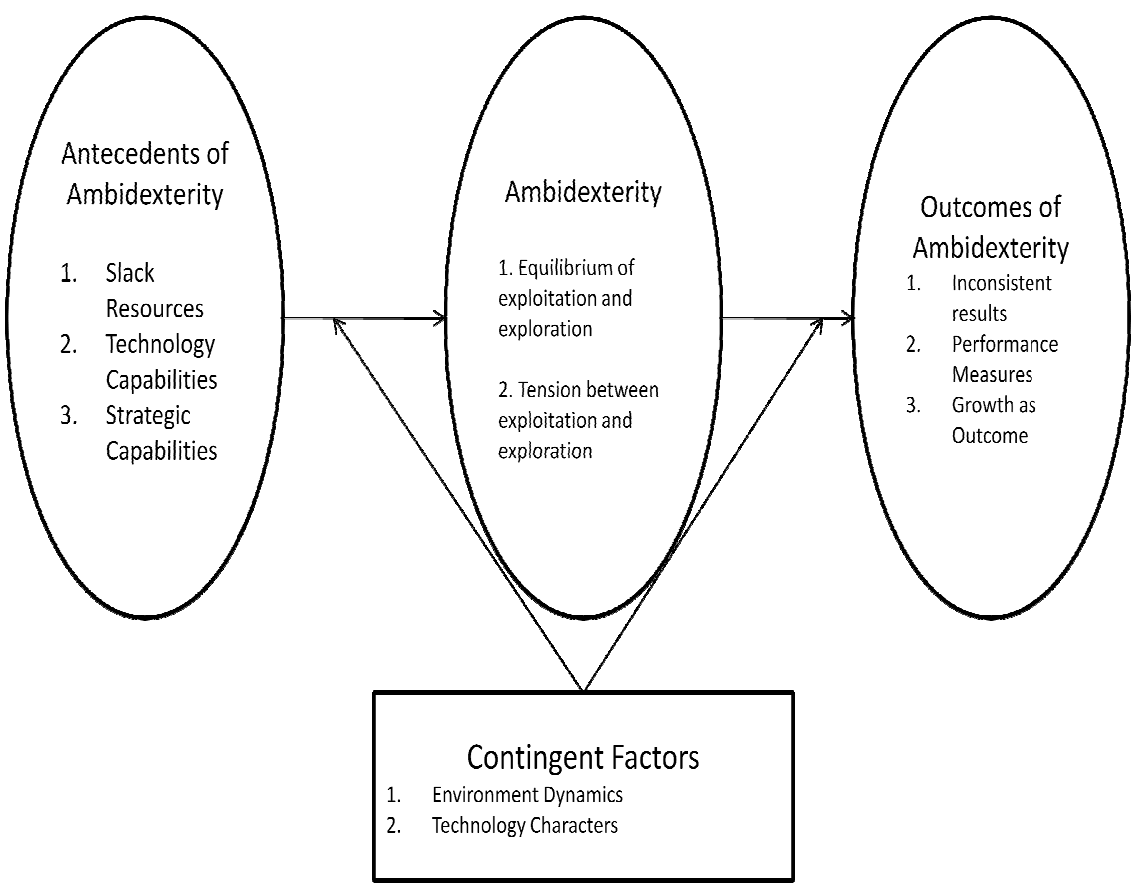

In this dissertation, ambidexterity is defined as a balance of the exploitation of knowledge and the exploration of knowledge. Exploitation involves refinement, efficient use and local search for knowledge while exploration involves flexibility, experimentation and distant search of knowledge (Gupta et al. 2006; Raisch, Birkinshaw, Prost and Tushman, 2009). The dichotomy of exploitation and exploration has been studied in different domains including strategic 
management (He and Wong, 2004; Uotila, Maula, Keil, and Zahra, 2009), innovation

management (Benner and Tushman, 2002; Jansen et al. 2009), alliances (Koza and Lewin, 1998; Rothaermel and Deeds, 2004), technology sourcing and organizational design (Rothaermel and Alexandre, 2009; O'Reilly and Tushman, 2004). I used keywords, including "exploitation", "exploration" and "ambidexterity" to search for articles in major journals in these management fields. These articles were summarized in Appendix B.

\subsection{Theoretical development of ambidexterity}

The exploitation and exploration topic has been of interest in management and social science for decades (Levitt \& March, 1988; March, 1988). The literature on ambidexterity has evolved in a variety of fields including organizational learning and technology management as well as population ecology. This evolution helped us better understand firm capability to balance exploitation and exploration (Gupta et al. 2006, Raisch et al. 2009). I start the review with studies of exploitation and exploration in order to demonstrate the evolution of developing the concept of ambidexterity.

\subsubsection{Dimensions of the construct of ambidexterity}

Nelson and Winter (1982) argued that exploitation denotes firm activities associated with the evaluation of current routines, and their modification or replacement. Population ecology literature argues that modification of routines and practices is crucial to the survival, and generation of new routines and practices is equally essential. Organizations exploit their existing competencies and learn from experience (Levinthal and March, 1993) and the lessons of experience can be transferred from one operating unit to another. Firms can build their competitive advantage based on exploitation of such experiential knowledge. Stalk, Evans and Shulman (1992) argued that successful firms have capabilities to respond to experience by 
modifying their technologies, forms and practices. Moreover, existing routines may exert a positive influence on innovation development (Nelson and Winter, 1982).

However, experience may not be a good teacher, especially for solving complex and changing problems. And, structural inertia may negatively affect firm capability to rapidly adapt itself to the environment (March, 1991). Even highly successful companies face the difficulties of using experience to interpret the complex world (Levinthal and March, 1993). Moreover, possessing capabilities to exploit existing experience may reduce the incentives to seek new knowledge and paradigms (Nelson and Winter, 1982).

Exploration of new knowledge is likely to be associated with long term success for many organizations (Levinthal and March, 1993). And the literature generally associates exploration with the terms such as: search, variation, risk taking, experimentation, discovery and innovation. The exploration process involves activities such as recognizing new opportunities and creativity. Also, non-local search for knowledge often leads to innovative strategies (March, 1991). Thus firms may choose to pursue multiple trajectories of knowledge (Nelson and Winter 1982). Given that firms often seek radical changes when exploring, these exploration-based activities are often associated with long-term outcomes and significant risks. Therefore exploration requires organizations to manage environmental uncertainty (Levinthal and March, 1993).

Katila and Ahuja (2002) defined local search and non-local search with respect to technological search. They define search depth as “the degree to which search revisits a firm's prior knowledge" (exploitation) and search scope as "the degree of new knowledge that is explored" (exploration). These search activities can achieve an optimum level: that's where the number of new products reaches the highest point. They contribute to the literature by arguing 
that there is not a single dimension that represents a trade-off between exploitation and exploration, but that these concepts represent independent dimensions.

Alliance portfolios have been used to understand the capabilities of exploring and exploiting different resources in inter-firm relations and emphasize the importance of such capabilities needing to fit with firm, strategic and industry conditions. In this context, scholars consider research and development $(\mathrm{R} \& \mathrm{D})$ based alliances as exploratory in nature while those whose primary purpose is establishment of efficient transactions, such as licensing alliances, marketing alliances and supplying alliances are considered as exploitative in nature (Koza and Lewin, 1998).This provides another domain in which firms can pursue exploitation or exploration.

\subsubsection{Construct development of ambidexterity}

March (1991) argued that firm survival and prosperity depend on a balance between exploitation and exploration. He assumes that exploitation and exploration activities compete for scarce resources, thus firms may make decisions to pursue equilibrium of exploitation and exploration. Therefore, successful firms learn through experience about how to divide resources between exploitation and exploration. And ambidexterity performance is determined by the joint function of potential return from an innovative activity and present competence of the firm. Additional organizational learning research examines the dynamic friction between exploitation and exploration and argues that there exists a trade-off between exploitation and exploration. Sometimes exploitation drives out exploration, since the return from exploitation is more certain than the return from exploration; and, exploitation can also help with increasing competence and the opportunity cost of exploration (Levinthal and March, 1993). Although return from exploration is less certain and consumes more time than exploitation process, exploitation of an 
existing competence, especially an inferior activity, can create path dependency and further become self-destructive. Therefore, it is not an easy task for firms to achieve both activities.

More recent studies investigated the performance of ambidextrous organizations, which are defined as organizations pursuing exploration and exploitation simultaneously (Benner and Tushman, 2003; He and Wong, 2004). In the organizational learning literature, long-term organizational performance requires ambidextrous capabilities, especially in a dynamic environment. Organizations can generate competitive advantages through incremental development as well as revolutionary and evolutionary changes. However, firms are confronted with a dilemma between exploiting existing competencies and exploring new capabilities. Therefore successful firms are those who can resolve the tension between exploitation and exploration activities to develop an ambidextrous capability. These firms further achieve a long term superior performance (Vera and Crossan, 2004).

Levinthal and March (1993) pointed out that emphasis on both exploration and exploitation, directed to achieve ambidexterity, may reduce the detrimental impact of excessive exploration as well as that of detrimental inertia. Organizations may learn to accelerate exploitation or exploration, and this learning approach may create negative as well as positive contributions to their competitive advantages. The transition between exploitation and exploration also challenges the organizations. Changes in structural, cultural and operational elements make the firm especially vulnerable to the liability of exploitation. And the more radical the new experiment approach from exploration, the more serious the disruption to the existing activities to exploit the competitive advantages (Gibson and Birkinshaw, 2004; Raisch et al., 2009). 
These studies were built on March's (1991) arguments and emphasized a competition perspective where the tension between exploitation and exploration causes challenges for these firms to balance these two tasks, because firms that pursue both exploitation and exploration are considered as lacking focus (Miller and Friesen, 1986). In addition, exploitation and exploration may compete for limited firm resources (He and Wong, 2004)

Scholars began to argue that a balance can also be achieved by the temporal and spatial nature of firms' capabilities_-treating exploitation and exploration as complementary tasks (Holmqvist, 2004). The mere coexistence of exploitation and exploration is necessary but insufficient condition for understanding the benefit of ambidexterity (Raisch et al., 2009). Moreover, exploitation and exploration require different managerial mindsets and coexistence requires people working in different "thought worlds". Therefore, we need a way to integrate both extremes rather than accepting a simple trade-off between exploitation and exploration (Raisch et al. 2009). Gupta et al. (2006) and Lavie et al. (2010) both pointed out that it is crucial to better understand the concept of a balance on a "punctuated equilibrium" or "temporal evolution" between long term, progressive, exploitation and short bursts of exploration. Venkatraman, Gilsing, Beerkens and Duysters (2009) found sequential ambidexterity to be more effective in the software industry. They measured sequential ambidexterity as "a temporal sequence of routines that balance exploration (i.e., time t-1) and exploitation (i.e. time t) in two successive time periods". However, most of the ambidexterity studies still neglect the importance of distinguishing the competition perspective from the complementary perspective of these two tasks (Lavie et al. 2010; Gibson and Birkinshaw, 2004). 


\subsubsection{Antecedents to ambidexterity}

Although scholars have articulated ambidexterity as a mechanism affecting firm performance, there is lack of research studying the antecedents to ambidexterity (Raisch and Birkinshaw, 2008; Voss, Sirdeshmukh, and Voss, 2003). In addition, the literature focused on drivers of ambidexterity has produced mixed evidence. In this section, I summarize multiple factors which have been identified as predictor of a firm's tendencies to explore, exploit or work for a balance of both activities (Lavie et al. 2010). Those factors, which researchers have included, and firms need to develop to achieve ambidexterity performance, include slack resources, specific capabilities and certain organizational structures (Holmqvist, 2004). Resources and knowledge. Resources are considered as crucial to the innovation process (Sorensen and Stuart, 2000). And, young and small firms face the liability of newness since they lack sufficient resources, thus they are considered as less capable to effectively operate and to create procedures for survival. Voss et al. (2008) focused on slack resources to explain the innovation process. Slack resources include unabsorbed financial, operational and human resources. These resources stimulate exploration in a highly threatening environment, while slack resources foster exploitation when competitive intensity is moderate. However, some scholars have argued that larger firms introduce less radical innovation (Damanpour, 1996). Therefore, it is not possession of slack resources which drives the development of ambidexterity, but effective management of resources which fosters ambidexterity. Cao, Gedajlovic and Zhang (2009) found that, in the Chinese context, firms with access to more resources can benefit from simultaneously pursuing both exploitation and exploration. And, if firms constantly manage the trade-off between these two activities, ambidexterity is more beneficial to firms with limited resources. 
More recently, the ambidexterity literature has employed cognitive and behavioral insights in order to understand how managerial resources can achieve superior performance through exploitation and exploration (Benner and Tushman, 2004). Ambidexterity challenges the cognitive ability of top managers. Researchers argued that successful firms are those which can manage tensions created by exploitation and exploration processes. The impact of the resources from the top management team has been investigated as well (Andriopoulos and Lewis, 2009). This research argued that top managers play an integrative role in combining exploitation and exploration in business units. And, senior managers are responsible for creating a context to facilitate a balance of exploitation and exploration. Jansen et al. (2009) investigated the role of formal and informal integration of senior management teams. Senior teams are expected to recognize different ambiguous and conflicting expectations between exploitation and exploration. Therefore it is crucial for them to resolve the tension in order to create synergistic value to achieve ambidexterity. They also found that senior members who shared a vision and received contingency rewards were more likely to pursue ambidexterity than those who did not. Beckman (2006) argued that the founding team's experience, including their prior company affiliations, can predict whether a firm pursues exploratory and exploitative behaviors. Prior affiliations of management team members shape firm exploitation and exploration. Teams with common prior company affiliations are more likely to pursue exploitation while teams within which members come from a wide range of previous affiliations are more likely to pursue exploration. In addition, firms whose management teams have diverse and common affiliations are more likely to pursue a mix of exploitation and exploration. He also found that firms with a founding team whose members have multiple affiliations tend to achieve at least one form of superior performance, such as sales growth. 
Special Capabilities. In addition to resources, Bierly, Damanpour and Santoro (2009) have identified both technological capabilities and strategic competencies for predicting exploitation and exploration processes. Kane and Alavi (2007) argued that investment in information technology positively affects ambidexterity development. Zhou and Wu (2010) argued that technological capabilities, which offer the skills and abilities to deploy and utilize various resources and know-how, predict exploitation and exploration of new products. By employing theoretical arguments and findings from the literature on absorptive capacity, as well as the literature on organization inertia, they found that a high level of technological capability impedes explorative innovation while it fosters exploitative innovation. In this study, they found that technological capabilities have different effects on exploitation and exploration innovation. But, they argued that firms invest in developing technological capabilities in order to achieve either exploitation or exploration performance, thus their study didn't help develop an understanding of how firms can invest in building a balance of exploitation and exploration.

Organizational Structure. Furthermore, research has investigated the development of the organizational structure which allows firms to achieve an ambidextrous capability. In a highly centralized organization, exploration is hindered. Jansen et al. (2009) argued that centralization negatively affects exploratory innovation whereas formalization positively influences exploitative innovation. This is based on how the coordination mechanism impacts routine operation, formal duties, power, and problem solving process. Building on the organizational learning literature, Fang, Lee and Schilling (2010) pointed out that firms invest in structural development, thus successful semi-isolated subgroups lead to capability development for a balance of exploitation and exploration. 
Researchers have evolved to focus on firms' investments in both external and internal coordination mechanisms to affect ambidextrous capability (Rothaermel and Alexendra, 2009). Teece et al. (1997) identified that 1) intra-firm coordination, 2) inter-firm coordination, 3) and integration enhance the strategic advantage from exploitation and exploration. These coordination systems could include: alliances, partnerships, buyer-supplier relationships, customer relationships, and collaboration on R\&D. Firms learn through the process of social and collective coordination. In this way, firms can keep constantly searching and evaluating practices and knowledge. And these search and evaluation activities, involving collaboration outside the organization, are crucial for both exploitation and exploration.

In addition to collaboration and integration, firm culture has been identified as an essential force in driving exploitation and exploration (O'Reilly and March, 2004). An organization can have a culture characterized by opportunism, experimenting, risk taking, decisiveness and taking initiatives. These cultures allow creative thinking, furthermore encouraging innovativeness for exploration.

Multilevel Effects. While studying antecedents to ambidexterity, the field called attention to an integrative model to incorporate interactions of multi-level effects. March (1991) mentioned that the difficult part of finding such a balance is the fact that a nested system at different levels - individual level, organizational level and social level - makes the choice more complicated. In his study, March created two different social contexts: one is a mutual learning process between the organization and individuals in it; the other is a competitive process for primacy. In both situations, individuals, organizations and social contexts were taken into consideration and firms were assumed to make strategic choices for performance. But March didn't distinguish mature firms from entrepreneurial ventures to understand the development of 
ambidexterity and performance, although learning, imitation and adaptation may provide different alternatives and processes for these two types of firms.

A growing body of literature has acknowledged the importance of ambidexterity in interorganizational relationships (Clark, 1989; Koza and Lewin 1998). Firms enter into exploration alliances in order to seek opportunities. They also engage in exploitation alliances in order to enhance efficiency and gain incremental performance by leveraging complementary resources. Hoang and Rothaermel (2010) found that firm internal capabilities regarding exploitation and exploration could interact with alliances experiences, and thus impact R\&D projects' performance. Im and Rai (2008) found that building ambidextrous learning can enhance interorganization relationships, and this effect is positively moderated by relationship duration. Zhou and $\mathrm{Wu}$ (2010) also found firms' strategic flexibility can serve as a contingent factor, moderating the relationship between technology capabilities and innovation strategies.

Conclusion Regarding Antecedents. Although more studies have examined antecedents to exploration versus exploitation, there is still a lack of consistent theoretical arguments and empirical evidence for a deeper understanding of this topic. First, most of the current studies have focused on drivers to either exploitation or exploration, thus there exist gaps in conceptualizing how firms invest to develop a balance of exploitation and exploration activities (Lavie et al. 2010). Second, the current literature lacks a comprehensive framework demonstrating the interactions of antecedent factors. Environmental, organizational and managerial factors may need to be combined together to explain firms' inclinations towards developing an ambidextrous capability. Therefore, my study provides an integrated framework to investigate how different drivers can interact with each other to develop an ambidexterity. 


\subsubsection{Outcomes of ambidexterity}

March (1991) not only defines both exploitation and exploration, but also identifies the outcomes of these actions. He modeled the effect of developing organizational knowledge and how firms learn through the process. And he found that exploitation reduces the variation of individual learning while it increases learning performance. And exploration increases both average performance and heterogeneity, which further impacts firm survival.

Empirical studies have shown that organizations benefit from an ambidexterity approach (He and Wong, 2004; Sidhu, Commandeur and Volberda, 2007). Tushman and O'Reilly (1996) were first to present the concept of ambidextrous organizations and they found that ambidextrous organizations can experience superior performance. Gibson and Birkinshaw (2004) found that ambidexterity enhances performance by using a small sample of firms and subjective measures for performance. He and Wong (2004) found that the interaction between exploitation and exploration strategies indeed positively impacts firms' sales growth. Their study showed that overemphasis on either exploration or exploitation negatively affects revenue growth. But measurement of the growth outcome has not been well implemented to enable a more comprehensive model of ambidexterity development.

As shown in Appendix B, current studies on ambidexterity, however, still produce inconsistent results. Rothaermel\& Alexandre (2009) found that the relationship between the technology sourcing mix and firm performance is an inverted U-shape. Uotila et al. (2009) also found an inverted U-shaped relationship between the relative share of exploratory orientation and financial performance. Bierly and Daly (2007) found that the relationship between exploration and performance is linear and positive, while the relationship between exploitation and performance is concave. One of the explanations why these studies produce inconclusive results 
is that studies have examined various performance outcomes when analyzing the impact of a balance between exploitation and exploration.

One of the most common measures for ambidexterity performance is volume of new product development (Katila and Ahuja, 2002; Rothaermel and Deeds, 2004). However, empirical evidence on the impact of ambidexterity on firm financial performance is still limited. A few measures, including revenue, cannot provide a complete picture of firm performance. Critics of the literature request more longitudinal studies to understand ambidexterity performance (Gibson and Birkinshaw, 2004; He and Wong, 2004). This is crucial to understand how high technology organizations can pursue both exploitation and exploration of innovation. Exploitation of innovation refers to short term efficiency and refinement while exploration of innovation is associated with long term performance under uncertainty. To be able to function effectively in a fast growing environment, organizations have to excel in both short term and long term performances.

Conclusion Regarding Outcomes. One of the explanations of why previous studies produce inconclusive results is that studies have examined various performance outcomes when analyzing the impact of a balance between exploitation and exploration. Exploitation activities refer to those behaviors focused on short term efficiency and refinement while exploration is associated with long term goals. Therefore, in order to understand ambidexterity, longitudinal studies are needed. My study addresses this need by focusing on long term growth to measure firm performance. Furthermore, growth was selected because it is considered the mechanism through which other outcomes, such as profitability, are achieved, and it is an important goal for new ventures to achieve in and of itself (Slevin and Covin, 1997; Shane, 2000). 


\subsubsection{Contingent factors for ambidexterity and performance}

Previous studies produced inconsistent results about the impact of exploitation and exploration on firms' performance. Therefore, a few scholars have focused on identifying contingent factors which may moderate the positive effects of ambidexterity. These contingent factors include external environmental dynamics such as environmental threats, industrial dynamics and environmental uncertainty, as well as technological characteristics, including tacit knowledge and technological compatibility (Fang and Levinthal, 2009; Voss et al., 2008). According to the contingency perspectives (Olsen, Walker, and Ruekert, 1995), the external fit that firms operating in a stable environment experience will impact how firm successfully exploit existing knowledge. This is based on the logic that existing competencies become obsolete quickly in dynamic environments, calling for the development of new competences. Therefore, firms may increase exploration in a dynamic environment (Levinthal and March, 1993).

Environmental factors have been studied as moderators to the impact of exploitation/exploration on firms' performance (Jansen et al. 2009). Jansen et al. empirically examined the effect of competitiveness on organizational ambidexterity using cross-sectional survey data. They found that competitiveness positively moderates both exploration and exploitation performance. In environments with weak intellectual property rights, as well as low strategic complexity and low ambiguity, the benefits of exploration may be difficult to achieve (Rivkin, 2000). In addition, exploration conducted by a few firms may actually benefit competitors rather than the exploring firms (Levinthal and March, 1993).

Lin, Yang and Demirkan (2008) found that, in an uncertain environment, having an ambidextrous competence enhances firm performance while a focused strategy on either exploitation or exploration enhances firm performance in a stable environment. Bierly et al. 
(2007) found that the competitive environment moderates the relationship between exploitation/exploration and firm performance. For example, in a stable environment, exploitation is more likely to relate to performance while exploration has stronger impact in a high technology environment.

Other contingent factors, such as $R \& D$ intensity, also captured the variance between exploitation/exploration and firm performance. Uotila et al. (2009) found an inverted U-Shaped relationship between an explorative /exploratory orientation and financial performance. And this relationship is positively moderated by $R \& D$ investment. In addition, contingent factors in existing studies provide evidence that interaction between firms' internal capabilities and external relationships predicts ambidexterity performance (Rothaeremel and Alexandra, 2009).

Conclusion Regarding Contingent Factors. Previous studies focused on environmental dynamics and external relationships to identify moderating effects on ambidexterity. Although the existing literature promotes the fit perspective to better understand ambidexterity, the literature lacks a unified framework of external factors, including both dyadic relationships and environmental dynamics, to understand the joint effects these external factors have with internal ambidextrous capability (Lin et al, 2008). Moreover, contingent factors have been well applied to understand a "trade-off" between exploitation and exploration, and the question of under what condition temporal or spatial balance of exploitation and exploration is associated with performance, is less explored. Therefore, my study attempts to provide and test such a unified framework to understand how multi-level factors impact a temporal balance of exploitation and exploration. 


\subsubsection{New ventures' ambidexterity}

Rothaermel and Deeds (2004) found that new ventures in the biotechnology industry use an integrative alliance system to leverage exploitation and exploration in a sequential way. Their study stimulates the interest in the ambidexterity literature on differences between mature companies and new ventures. Exploitation and exploration are crucial for new ventures because these firms tend to possess less advanced technology and knowledge compared to large established firm. Given this context, whether new ventures become effective depends upon how successfully they balance exploitation and exploration of knowledge in order to pursue a long term learning path. However, the literature on new ventures' ambidexterity is still underdeveloped.

Though the literature on new ventures' ambidexterity capabilities is not well explored, these young firms provide a context to better understand the ambidexterity development process including antecedents, outcomes and contingent factors. For example, from the antecedent perspective, previous literature has argued that slack resources are one of the key factors for developing ambidextrous capabilities. New ventures lack specific resources, a sufficient customer base and the necessary investments in their structures. They are assumed to be more susceptible to failure because of their "liability of newness". Therefore, investments in resource allocations, capability developments and equilibrium structures are required to develop an ambidextrous capability. This is not saying that new ventures need to maximize both capabilities in order to achieve the optimal value.

In my study, I focus on how international new ventures can build technological knowledge during their initial stages, as well as the alliances developed and their geographic locations, in order to develop an ambidextrous capability. In terms of outcomes, critics of the 
literature request more longitudinal studies to understand the effects of ambidexterity (He and Wong, 2004). Growth has been identified as one of the key performance measures for entrepreneurial firms (Shane and Venkataraman, 2000). Growth is also a measure for long term performance. In this sense, new ventures provide a logical and appropriate sample for investigating the relationship between an ambidexterity capability and firm growth.

\subsection{Review of international new venture literature}

\subsubsection{Internationalization of MNCs}

Internationalization is the process of a firm's growing involvement in operations across national borders. The Internationalization process has been studied from the resources-based view and the dynamic capabilities perspective. The resources-based view (Penrose, 1959; Barney, 1991) and the capabilities-view (Teece, Pisano and Shuen, 1990) both argue that firms enter into new markets to exploit their core competencies, and therefore benefit from both economies of scale and economies of scope. Scholars suggest that firms tend to enter a market which is related to their existing resources or capabilities (March, 1991; Nelson and Winter, 1982). This view argues that the mature MNCs tend to go abroad through an incremental process.

Previously, the international management literature has employed international business, as well as a transaction costs and resources-based view, to emphasize rational and strategic decision-making criteria, such as costs, investment, risk and control. This stream of literature builds arguments on the assumption that foreign market entry decisions consist of discrete alternatives at specific and identified points in time. In addition, the network literature, as well as resource dependency and organizational learning literature, focuses on a process in which 
internationalization takes time, involving an incremental learning process (Kogut and Zander, 1995).

A major theme in the internationalization literature is that MNCs tend to choose the incremental growth model. Those works acknowledge the capability of large MNCs to create, disseminate and leverage knowledge in a global context through both headquarters and preexisting subsidiaries (Ghoshal \& Bartlett, 1990; Gupta \& Govindarajan, 2000; Kogut \& Zander, 1993; Kostova \& Roth, 2003; Nohria \& Ghoshal, 1997; Tsai, 2002). The path-dependent nature of experiential learning suggests that the likelihood of internationalization will be stronger as firms accumulate more experience. However, this tendency may lead firms to develop "corerigidities" and fall into "competence traps" (Levitt \& March, 1988). Meanwhile, this theoretical argument cannot explain the fact that some new ventures initiate international activities at an early stage with a fast pace.

In many studies about the incremental internationalization process, there exists another view about how experiences guide new market entries. Johanson and Vahlne's (1990) model implies four stages of gradually increasing foreign involvement in which firms follow their way to become internationalized. This is considered a path-dependency approach, which involves acquisition, assimilation and integration of experiential knowledge. This experiential learning process may not require higher levels of resource commitment until the firms acquire increasing levels of experiential knowledge. Based on this view, the more experiences firms gain, the more likely they are to choose an area related to that knowledge. The path-dependent nature of this experiential learning suggests that the likelihood of internationalization will be stronger as firms accumulate more experience. In addition, the model developed by Johanson and Vahlne doesn't have a specific time dimension to explain internationalization. 


\subsubsection{Internationalization of new ventures}

International new ventures are those firms which start internationalization at their early stages of development and overcome their newness liability to operate in other countries. These firms discover, evaluate and explore opportunities in multiple countries (Oviatt and McDougall, 1994; Oviatt and McDougall, 2005). Usually, they don't benefit from the same advantages as MNCs do. These advantages include economies of scale and sufficient resources. New ventures may not be able to build strong skills and knowledge in their domestic countries before they start operations in other countries. However, they grow internationally in spite of insufficient initial resources and turn disadvantages such as insufficient resources and newness liabilities into the foundation for identifying opportunities.

New arguments have emerged to provide distinctive explanations about the internationalization processes of new ventures compared to the internationalization processes of the MNCs. Oviatt and McDougall (1994) provided a theoretical framework to answer the question of why international new ventures exist. In their study, international new ventures are defined as a "business organization that, from inception, seeks to derive significant competitive advantage from the use of resources and the sale of outputs in multiple countries". Oviatt and McDougall (1994) pointed out that entrepreneurial firms don't benefit from some of the advantages of the MNCs, such as economies of scale or abundant resources. They pursue internationalization processes without initial resources; in addition, they may not be able to build strong skills and knowledge in their domestic countries before they start operation in other countries. However, these new ventures grow internationally in spite of these initial disadvantages and turn those disabilities into sources of advantage. This is not to say that international new ventures do not expand their core competence. The process through which the 
new ventures upgrade their capabilities is constrained by their pre-existing experiences and capabilities.

Since Oviatt and McDougall (1994) provided a theoretical framework for international new ventures, academics have developed a broad literature about how young ventures internationalize, and these works include research grounded in strategic management, international business, entrepreneurship, as well as marketing and innovation management (Knight and Cavusgil, 2004; Oviatt and McDougall, 2005; Zahra, 2005; Zahra, Ireland and Hitt, 2000). These works provide distinguished frameworks to explain internationalization among new ventures compared to those frameworks based on the more traditional views of the internationalization process of MNCs. However, I argue that the international entrepreneurship literature overemphasizes the distinctive features of exploration while the more traditional view can provide a solid explanation of exploitation activities for international new ventures. It is essential in the international management literature to bridge the traditional view of internationalization and the entrepreneurial perspective.

In the following sections, I first review the studies focusing on the internal capabilities for international new ventures, and identify the gaps and problems in the literature in this context. Second, I review studies that tested the framework to evaluate relational factors for new venture internationalization. I select the articles by searching academic works citing McDougall and Oviatt (1994). And the major journals in the management field are included. More details about these articles are included in Appendix C.

\subsubsection{Internal capabilities for new ventures internationalization}

Researchers have applied Oviatt and McDougall's (1994) framework in explaining the phenomenon of international new ventures, "born globals", accelerated internationalization and 
international entrepreneurship (Zahra et al., 2000; Zahra, 2005). Most of the theoretical frameworks tried to answer the questions how and why some firms can successfully internationalize early and rapidly while others cannot. The literature argues that these young firms follow a more radical approach to internationalization than traditional MNCs (Knight and Cavusgil, 2004; Oviatt and McDougall, 2005; Zahra, Ireland and Hitt, 2000). Oviatt and McDougall (2005) provided a framework to understand the speed of internationalization of new ventures. Their study demonstrated a comprehensive picture, incorporating environmental factors and firm orientations factors. However, they also pointed out their concerns that more refined theoretical arguments from the international management literature, as well as the entrepreneurship perspective, are required to understand this phenomenon.

Some factors, which researchers have included to understand new ventures' internationalization speed, include age, resources and specific capabilities. And, according to their original definition, age at the time of internationalization is assumed to have implications for firms' successful expansion, survival and financial performance (Zahra, 2005). Given this assumption, pre-launch experience has been identified as a key factor predicting international new ventures' performance. These experiences can influence a firm's predisposition to take the risks associated with internationalization, and its capability to allocate resources in order to gain competitive advantages.

Coviello (2006) provided a comprehensive review of the internationalization process of SMEs. In this study, the internationalization process of SMEs was defined as "the process by which firms both increase their awareness of the direct and indirect influence of international transaction s on their future and establish and conduct transactions with other countries". The resource-based view has been applied to answer the questions about how new ventures can gain 
competitive advantages in a global market. George (2005) argued that resource slack or specialized resources are prerequisite for entrepreneurial actions in an international context. However, Sapienza et al. (2006) pointed out that resources can also create constraints for entrepreneurship. Mathews and Zander (2007) found that it might be the availability of resources and opportunities in the international environment that stimulate entrepreneurs to be involved across nations, given the lack of resources in their home country.

Autio (2005) did an in-depth discussion of common points and conflicting views between the international new ventures models and the gradual process models of internationalization. The factors used by the gradual process models, including resources, value creation, capabilities to exploit position opportunities, and knowledge creation advantages, can also serve as the key sources for internationalization capabilities of new ventures.

Some studies employ theories from other fields to explain the internationalization process. Liesch and Knight (1999) used the hurdle rates perspective to explain "what is the role of information in Small \& Medium Enterprise (SME) internationalization and how might SMEs recognize when to pursue a particular internationalization project". The theoretical framework from their study provided insight on the role of information on the internationalization process, which provides consistent arguments and robust theoretical discussion with regard to the gradual model, which explained traditional internationalization process. However, their study didn't distinguish new ventures from other SMEs to explain how information plays role for both types of entrepreneurial firms. Thus, their study provides further direction to investigate how information impacts new venture internationalization when these young firms face newness liability. 
As the literature on international new ventures continues to develop, there is a need to further focus on the development of its theoretical foundation. More specifically, we need to push for the theoretical understanding of the initial stages of internationalization. For the research on new ventures, this can be achieved by examining such questions as: how do entrepreneurs invest in developing certain capabilities in order to successfully gain competitive advantages in the global market (Keupp and Gassmann, 2009). To better investigate this question, the international entrepreneur literature needs to incorporate theoretical perspectives from both international business and entrepreneurship theory. Such a strong theoretical foundation will allow research to progress through the development of clear propositions and testable hypotheses (Jones \& Coviello, 2005).

\subsubsection{External sources for new venture internationalization}

Research about the impact of the institutional environment on international new ventures has yielded a number of important findings. From the institution perspective, organizations tend to imitate actions taken by a large number of socially proximate organizations because new ventures have a strong need to gain legitimacy. When practices are frequently taken-for-granted and then adopted, new venture managers may choose to internationalize in response to risk and uncertainty. At the geographic location level, the knowledge spillover literature has emphasized how entrepreneurs benefit from co-locating with knowledge-rich institutions, but there is a dearth of research examining how these geographically-constrained knowledge spillovers impact the internationalization of new ventures (Fernhaber, Gilbert, and McDougall, 2008). At the industry level, although Oviatt and McDougall (1994) mentioned industry effects on the internationalization of new ventures in their theory development article, there are only a few 
studies which really investigate the industry as having institutional effects in depth (Fernhaber et al. 2008).

Fabian, Molina and Libianca (2009) used neo-institutional theory to explain how societal expectations impact organizational actions, which result in isomorphism among businesses operating in the same environments. For instance, from the decision-making perspective, the knowledge provided by institutional peers can provide opportunities to develop incentives to enter another market. In their study, frequency-based, trait-based and outcome-based imitation has been identified as predicting SMEs' internationalization in an emerging market. Built on samples from Colombian areas, their study showed that the role of institutional imitation can increase the likelihood that internationalization practice is chosen by SMEs.

Another stream of theoretical works on international entrepreneurship is focused on how social networks impact international entrepreneurs. The important role of relationships and the social context in capability development has been studied in this literature. The networks built in home countries can help entrepreneurial firms learn capabilities and access resources. However, there exists an imbalance between network level and firm level contributions. Specifically, certain firm-level and network-level characteristics, in combination, may be fruitful to the firm; therefore, firms embedded in social networks internationalize more rapidly with greater success than others (Rialp et al. 2005).

Knowledge exchange across organizations has also been studied as a driver for early internationalization of the firm (Zucchella, Palamara, and Denicolai, 2007). Strategic alliances and cooperative ventures represent powerful organizational arrangements that facilitate the process of relational learning and knowledge acquisition. Through inter-organizational learning, new ventures may actively engage in knowledge-sharing networks and acquire the knowledge 
required for their foreign expansion (Al-Laham \& Souitaris, 2008). And, such networks provide for the transfer of knowledge that affects the stock of knowledge available to the firm. In addition, legitimacy plays a role in networks as well. For instance, the firm's ability to penetrate a foreign market might be limited by regulation, marketing experience and reputation. Network relationships are identified as critical to knowledge development and awareness for international entrepreneurs.

In terms of research settings, the empirical studies conducted so far have reported results from countries across the world. These countries not only include traditional, big trading countries such as the US, Canada, New Zealand, the UK, Germany, and Spain, but also emerging countries such as China, Taiwan, and Singapore. The differences across research settings provide a potential explanation for why environmental factors predict different results for international new ventures.

\subsection{Summary of literature review}

In brief, international growth is often seen as a firm's attempt to either leverage the existing knowledge in their domestic country or learn from host countries by exploring novel technologies and knowledge. Thus, knowledge acquisition in both domestic and international markets can be used to explain the processes of internationalization (Presutti et al. 2007). This

idea assumes that, the broader the international market scope of a new venture, the more learning sources a new venture would have in the further growth process (Zahra et al, 2000). The learning benefit of-early international expansion depends upon the firm's capabilities to exploit and explore knowledge learned from both domestic and foreign knowledge sources (Sapienza et al., 2006). 
The international entrepreneurship literature provides some explanations of how the international expansion of a new venture can lead to its organizational learning (Autio, Sapienza, \& Almeida, 2000; Oviatt \& McDougall, 1994; Sapienza et al., 2006; Zahra, Ireland, \& Hitt, 2000). Although the literature argued that new ventures' capabilities, such as management of slack resources, previous experiences and information, can drive their internationalization speed, these new ventures still lack organizational routines, some of them may have different knowledge bases at the initial stage and face less pressure to learn inter-organizational knowledge. Some new ventures may benefit from further learning through valuable knowledge sources provided by social networks and institutional environments. In my study, I intend to build and test a comprehensive model to explain how knowledge at different levels can possibly be sources for developing an international ambidexterity of new ventures.

International new ventures provide a nice context for understanding how these firms can develop competencies that exploit their core knowledge and explore new market opportunities for further growth. Most of the studies in the international entrepreneurship literature focused on describing and understanding the internal and external factors for the emergence of internationalization among new ventures (Rialp et al., 2005). However, the existing literature provides less explanation on how early internationalization impacts post-internationalization performance (Zahra, 2005).

Although a small number of studies investigated the outcomes, these works provided inconsistent results regarding the effects of internationalization on these new ventures. For example, McDougall and Oviatt (1996) found a positive relationship between internationalization and growth with respect to market share. But, Autio, Sapienza and Almeida (2000) found no evidence supporting the effect of internationalization on sales growth. And Carr 
et al. (2010) found that early internationalization leads to faster growth but Autio et al. (2000) found no relationship between early foreign market entry and growth. Furthermore, Carr, Haggard, Hmieleski, and Zahra (2010) also found that internationalization impacts the survival of new ventures while Mudambi and Zahra (2007) found insignificant results regarding the survival or mortality of the firm and early internationalization. Given these inconsistent and inconclusive results, further investigation is needed.

The potential outcome of international expansion is quite different for new ventures compared to MNCs. If globalization can be seen as the central factor in the rise of international new ventures, then international expansion should have a positive effect on the competitiveness of the firms. However, if the accumulated capability is seen as a critical core for successful firms, then the international expansion of new ventures may have both positive and negative effects. Therefore, in my study, I test the impact of different early internationalization dimensions and also include moderator effects, which may impact the relationship between internationalization and new venture growth. 


\section{Chapter 3 Theoretical Framework and Hypotheses Development}

In this chapter, I discuss the constructs of international exploitation, international exploration and international ambidexterity. These constructs are related to the entry timing, location selection and entry mode of new ventures. And these decisions are associated with internationalization processes and performance. Then, I provide conceptual arguments to analyze what factors drive the development of international ambidexterity. Furthermore, I develop my hypotheses based on the conceptual arguments in order to test a multi-level framework: internal knowledge structure possessed by new ventures, relational knowledge exchanges and local knowledge dynamics.

\subsection{Conceptualization of international ambidexterity}

A major theme in the internationalization literature is that MNCs tend to choose the incremental growth model. Those works acknowledge large MNCs' capability to create, disseminate and leverage knowledge in a global context through both their headquarters and existing subsidiaries (Ghoshal \& Bartlett, 1990; Gupta \& Govindarajan, 2000; Kogut \& Zander, 1993; Kostova \& Roth, 2003; Nohria \& Ghoshal, 1997; Tsai, 2002). In many studies about the incremental internationalization process, there exists another view about how experiences guide new market entries. Johanson and Vahlne's (1990) model implies four stages of gradually increasing foreign involvement in which firms follow specific steps to become internationalized. This is considered a path-dependency approach, which involves acquisition, assimilation and integration of experiential knowledge. This experiential learning process may not require higher levels of resources commitment until the firms acquire increasing levels of experiential knowledge. Based on this view, the more experiences firms gain, the more likely they are to choose an area closed to that knowledge. The path-dependent nature of this experiential learning 
suggests that the likelihood of internationalization will be stronger as firms accumulate more experience.

However, international new ventures are those who initiate their international operations at an early stage when they don't have experiences. Autio et al. (2000) pointed out the effect of two important issues (age and speed of internationalization) on the international growth of these new ventures. They challenged the role of international experience in the internationalization process by focusing on those firms which initiated foreign sales at an early stage. In their study, the concept of the "learning advantages of newness" was introduced, which suggested that flexibility at a young age facilitates the learning competency for international growth. Their study supported the argument that self-reinforcing learning enhances a proactive culture for international growth and a firm's capabilities to seek and exploit opportunities in international markets.

In the following section, I explain the notion of international ambidexterity built on international exploitation and international exploration. I would suggest that exploitative and exploratory activities explain what international ambidexterity consists of, while international ambidexterity is defined as achieving high levels of both international exploitation and exploration. Two key elements help to specify the international ambidexterity construct.

In my study, more specifically, building the concept of international ambidexterity can help answer the following questions: To what extent do new ventures achieve international ambidexterity? Can those who developed international ambidextrous capability accelerate their growth rate compared with those without this capability? How can they develop it? In addition, this proposed conceptual model also provides solutions regarding how this capability 
can be developed through three drivers including, resource advantages, information availability, and managerial mindset.

In this section, I conceptualize the notion of international ambidexterity to demonstrate the internationalization process of new ventures. International ambidexterity is defined as a firm's capability to pursue a balance of international exploitation and exploration. This capability is founded on new ventures' initial activities which need to be further developed and refined through international operations. These international operations are modified through both incremental and radical changes. Furthermore, new ventures need to make efficient development of intended investments in order to develop such international ambidexterity. New ventures invest in strategic resources and international experiential knowledge in order to build a balance between exploitation and exploration. And, these two tasks gradually develop dynamic capabilities for long term performance. First, international ambidexterity is built on the experience formed at the initial stage when new ventures are created; second, the capability improves and is developed through continuous intra-organizational knowledge creation and inter-organizational knowledge transfer. Through these processes, successful new ventures are those who can build international ambidexterity to gain competitive advantages.

\subsubsection{International Exploration}

Some new ventures initiate international operations without sufficient economies of scale or sufficient resources. To these new ventures, internationalization represents a search and experimentation process whereby firms explore a variety of strategies to find the right one for their competitive situation. Oviatt and McDougall (2005) redefined the attributes of international new ventures by integrating speed and international scopes into a combination of innovative, 
proactive, and risk-seeking behavior, which provide the foundation to develop the concept of international exploration.

Exploration activities, such as monitoring, searching and creating, are generally deliberate (Bengtsson, Eriksson, and Kock, 2005). This deliberate process is different from the incremental internationalization process. In the exploration activities, the entrepreneurial approach plays a large role in international expansion. Exploration activity helps new ventures develop new structures and new operations for their growth trajectory. Prior studies, such as Benner and Tushman (2003) as well as He and Wong (2004), have suggested that the exploratory strategy of innovation is designed to meet the needs for emerging customers. The internationalization process of new ventures, which predominantly are doing exploration activities, involves a shift from the domestic knowledge base to a different technology and international expansion trajectory. Thus the new ventures with more exploration activities are more likely to create new knowledge, and then positively impact international learning through a broader range of foreign knowledge.

Autio et al. (2000) pointed out the effect of age and speed of internationalization on international growth of firms. In their study, they focused on international new ventures and argued that these firms benefit from the "learning advantages of newness". Therefore international new ventures with flexibility at a young age facilitate the learning competency for international growth. Their study supported the argument that self-reinforcing learning enhances a proactive culture for international growth and firm's capabilities to seek and exploit opportunities in international markets. Thus, the proactive attitude is fundamental to explain why new ventures initiate international learning across borders with greater speed than others. 
An exploration-oriented new venture is more likely to build strong relationships in foreign countries because the locus of innovative search is more likely to reside within the external network, which is distinct from that in the home country. Thus, the exploratory learning involves a shift to a different trajectory to the knowledge created at the initial stage. As a searchoriented firm, new ventures pursuing exploration activities may seek opportunities in new countries in order to generate new products and technologies. Therefore, new ventures with a strong exploration orientation may compete on the speed of identifying business opportunities in other countries; and they tend to implement international operations at the early stage of their development.

Compared to having skill at exploitation, the exploration process relies on a strong network of relationships in different host countries (Cantwell et al., 2005; Frost, 2001). Therefore, their benefits are built upon a broader scope of activities in multiple locations. Given their lack of resources and knowledge, new ventures tend to build social networks in foreign countries rather than choose a governance structure with tight control. Such a new venture always creates a no-duplicate knowledge advantage, which may not be absorbed by other units, including the one in the domestic country. Thus, they may not have a strong incentive to build operations closer to the home country. I argue that:

For new ventures, international exploration represents early internationalization with broader scope of international expansion by entering in locations far from the domestic country.

\subsubsection{International Exploitation}

The Internationalization process has been studied from the resources-based view and the dynamic capabilities perspective. Proponents of the resources-based view (Penrose, 1959; 
Barney, 1991) and capabilities-view (Teece, Pisano and Shuen, 1990) have argued that firms enter into new markets to exploit their core capabilities, and therefore benefit from both economies of scale and economies of scope. Scholars who support these arguments suggest that firms tend to enter a market which is related to their existing resources or capabilities (March, 1991; Nelson and Winter, 1982). I argue that the resources and capabilities based views can provide a great foundation to explain the exploitation behaviors of new ventures.

New venture's international exploitation is determined by its initial core competences for international operations. Exploitation activities include evaluation, exploitation and commercialization operations, through which new ideas are materialized and introduced into the organization. International exploitation involves improvements in existing business routines and builds on the existing technological and international knowledge trajectory. New ventures pursuing exploitation activities meet the needs of existing customers and markets, thus they have developed their existing knowledge by refining established technological and customer competences in these countries where they already operate.

Studies focused on the exploitation of knowledge argued that innovation is, and ought to be, localized in the home countries and MNCs benefit from exploiting their knowledge ownership in different countries. Kogut and Zander proposed that MNCs can be considered as a social community within which knowledge can be transferred more smoothly across different countries. The intra-firm knowledge transfer provides competitive advantages for MNCs because of strong transfer barriers caused by institutional distance which makes knowledge transfer become more difficult for independent firms in the inefficient market (Kogut and Zander, 1993). From an exploitative learning view, firms with strong domestic experiential knowledge will benefit from knowledge ownership advantages in foreign countries because 
MNCs have been long considered as integrators of knowledge (Ghoshal and Bartlett 1990;

Kogut and Zander 1993; Kotabe, Parente, and Murray, 2007). Since the scope of exploited knowledge is determined by the routines that constitute the existing knowledge base (Frost, 2001), the later foreign entry strategies are built on the knowledge similarity with internal resources.

Exploitative learning is a sequential process, which may occur after new ventures gain sufficient experiences at the early stage of their formation. New ventures may start with entrepreneurial actions and exploiting the experiential knowledge in foreign markets, however, there is the time between the discovery or enactment of an opportunity and its first foreign market entry (Oviatt and McDougall, 2005). Timely and efficient diffusion of the knowledge among members in the network will enhance the value of successful learning beyond the networks where the international new ventures are initially embedded (Bartlett and Ghoshal, 1998; Hedlund, 1986). Therefore, new ventures with strong exploitative capabilities will be more likely to choose subsequent incremental internationalization approaches, rather than more rapid and asynchronous approaches.

For new ventures, international exploitation represents their late internationalization with narrower scope of the subsequent international expansion, by entering in locations similar to the domestic country.

\subsubsection{International Ambidexterity}

International ambidexterity is built on pursuit of international exploitation and exploration, thus it is necessary to make an assumption about whether the concepts of exploitation and exploration are orthogonal or complementary. Given the attributes of new ventures such as resource scarcity, the relationship between exploitation and exploration is likely 
to be mutually exclusive at one time (Gupta et al., 2006). Therefore, within a single knowledge domain, such as international market knowledge, exploration and exploitation generally alternate over time. There is also a notion of the balance between the exploitation and exploration. However, if the new ventures exploit in one knowledge domain, they can explore in another loosely coupled domain. For example, when new ventures exploit the technology to protect their knowledge ownership in one country, they can still explore in different international locations. This can be considered as spatial balance of international exploitation and exploration (Gupta et al., 2006). However, they are less likely to explore different technology domains at the same time. In other words, at different points in a new venture's internationalization process, either exploration or exploitation may dominate.

Meanwhile, a "punctuated equilibrium or temporal evolution" between a long term of accumulative exploitation and short bursts of exploration has also been identified to better understand the notion of a balance between the exploitation and exploration (Gupta et al., 2006). And the simultaneous aspect of ambidexterity is not the only dimension of a balance between exploitation and exploration. For instance, a new venture needs to achieve a certain level of knowledge stock before making the decision of early internationalization, and further the international growth is also based on the continuous exploitation of certain knowledge following a burst of the exploration.

Literature about dynamic capabilities argues that exploitation and exploration have to be recombined to create value (Eisenhardt and Martin, 2000; Teece, 2007). It is not an easy task for organizations to resolve this tension. This is not saying that new ventures need to maximize both capabilities in order to achieve the optimal value. And I mentioned earlier that the resources of new ventures are scarce, therefore, when they pursue both exploring and exploiting resources, 
the relationship is more likely to be sequential. Exploration and exploitation require fundamentally different and inconsistent architectures and competencies, thus creating a dilemma for new ventures (Benner and Tushman, 2003). I argue that new ventures need to build international ambidexterity as a dynamic capability that goes beyond just moving from one competence to the other, but-builds interaction with both to create value (Jansen et al. 2009). And the manager's task is to integrate the time equilibrium between those two approaches in the international expansion process, so the dynamic capabilities are enhanced through creating and sustaining such an international ambidexterity.

When new ventures emphasize too much on exploration for international operations, it increases the risk of failing to appropriate returns from the experimental activities. Therefore, firms need a balance between the two types of activities for long-term performance. In contrast to the competitive view of exploitation and exploration, the complementary view proposed by Gupta et al. (2006) demonstrated that "punctuated equilibrium" or "temporal evolution" between the long term use of accumulative exploitation and short bursts of exploration can be possible. Building on this notion, I argue that new ventures may use sequential adjustments to shift between exploration and exploitation. And the positive effects of exploitation can be drawn on to enhance exploration, and higher exploitative effects can also improve a firm's effectiveness in exploring new knowledge and in developing capabilities to gain competitive advantages in new markets (Cao et al. 2009). Once a new venture initiates new market entries, repeated use of existing knowledge can make a manager become more aware of current knowledge and have a deeper understanding of those current opportunities. Therefore, stronger exploitation through incremental entries will help new ventures to benefit from their early internationalization. Thus, early internationalization can be complementary to exploitative learning by new ventures. 
On the other hand, for those new ventures which can identify the optimal equilibrium for internationalization, competitive advantages emerge to support their further growth. Successful new ventures need ambidexterity while an imbalance between exploration and exploitation poses threats to firm performance. According to Cao et al. (2009), firms are more likely to be subject to the risk of obsolescence when their magnitude of exploitation exceeds that of their exploration. In the internationalization process, new ventures may risk path-dependency problems if they put too much emphasis on exploiting one domain of knowledge. Ambidextrous new ventures are required to have an early internationalization to achieve exploration in a highly competitive global market. Therefore, new ventures with an international ambidextrous capability will perform better in the long term than those with the incremental trajectory for internationalization. It is suggested that internationalization of new ventures implies rapid and incremental internationalization. Given this perspective, the existing competencies can quickly become outdated and further path dependency will slow down the growth process of new ventures.

For new ventures, international ambidexterity is defined as a balance of international exploitation and international exploration, more specifically broader scope of early internationalization with narrower scope of the subsequent international expansion.

\subsubsection{Summary of conceptualization of international ambidexterity of new ventures}

To begin, as Gupta et al. (2006) discussed, the central theme regarding definitions of exploitation and exploration lies in the type of learning. Therefore, in terms of whether new learning occurs along the same trajectory as previous knowledge or along a different trajectory, international exploitation is distinguished from international exploration by focusing on the type of incremental knowledge along with the trajectory of the knowledge path close to the domestic country or previous foreign entries. From a spatial dimension perspective, new ventures may 
keep incremental learning in limited regions while pursuing exploratory learning in new countries, continents or places with larger institutional distances.

Second, in keeping with Gupta et al. (2006) discussion of the temporal dimensions of exploitation and exploration, I view international ambidexterity as an organizational level construct that manifests in the organization's exploitation and exploratory attainments in a sequential manner. For a new venture, speed of internationalization is an important attribute of new venture internationalization. For example, McDougall and Oviatt (2005) specified initial entry, scope of international markets and commitment to internationalization as the key dimension to understand speed of entrepreneurial internationalization. Therefore international ambidexterity is defined as a temporal balance of international exploitation and exploration, more specifically an early internationalization followed by subsequent international exploitation.

Finally, I proposed a definition of international ambidexterity that highlights the idea of achieving high levels of performance in both exploitation and exploration. Punctuated equilibrium suggests that cycling between periods of exploration and exploitation is a more viable approach than simultaneously pursuing both.

I argue that the concept of international ambidexterity is strongly associated with the timing of a firm's decision to select international entry, to pursue a gradual learning process, to build a portfolio of international operations and to continuously evaluate outcomes for further development, including knowledge transfer and reverse transfer (Matthew and Zander, 2007; Sapienza et al. 2006). As shown in Table 1, new ventures are assumed to be born with the nature of international exploration. Only those who pursue early international exploration followed by later international exploitation are considered as new ventures with international ambidexterity. 
New ventures who didn't pursue early internationalization follow traditional international expansion as large MNCs.

Table 1 Key dimensions to conceptualize international ambidexterity for international new ventures

\begin{tabular}{|c|c|c|c|}
\hline \multirow{2}{*}{$\begin{array}{c}\text { Late } \\
\text { internationalization }\end{array}$} & \multicolumn{3}{|c|}{$\begin{array}{c}\text { Early Internationalization } \\
\text { Scope of International Expansion }\end{array}$} \\
\cline { 2 - 4 } & & Narrower & Broader \\
Scope of & & Traditional & International \\
International & & International & Ambidexterity \\
Expansion & Broader & Exploitation & \\
\cline { 2 - 4 } & & Traditional & International \\
& & International & Exploration \\
\hline
\end{tabular}

\subsection{Drivers of international ambidexterity}

Three essential elements serve as the building blocks for the driving forces to develop international ambidexterity. These elements include the advantages of firms' resources, as well as the contribution of information and the focus of managerial mindset. These three factors help us not only understand why some firms choose exploitation strategies while others emphasize exploration, but also explain why and how some new ventures can successfully build international ambidexterity. These factors are consistent with the strategic capabilities which I identified to understand the concept of ambidexterity in Chapter 2.

Resource Advantage. Resources and knowledge are considered as crucial to the learning process (Sorensen and Stuart, 2000). According to Barney (1991), unique resources help firms develop competitive advantages. Zahra et al. (2000) noted that, for new ventures, going international provides the greatest exposure for them to achieve technological learning. Oviatt and McDougall (2005) argued that entrepreneurs observe and interpret the potential of the 
opportunity, the potential of communication, transportation, and computer technology to enable internationalization, and the degree of threat from competitors. Therefore, new ventures need some resource advantages to identify these opportunities in global markets. New ventures that have unique assets with strong knowledge capabilities tend to be more likely to have strong absorptive capacity, and utilize some foreign location advantages. Therefore they are more likely to pursue a rapid internationalization.

This is also valid for explaining the international processes of new ventures. During the internationalization process, new ventures internalize some transactions with alternative governance structures (Oviatt and McDougall, 1994). Thus, the internationalization process can create resource advantages for new ventures. The higher the value of the resources is and the more unique the resources are the more likely new ventures are to choose exploitation to gain competitive advantages in multiple locations.

According to March (1991), slack resources may create exploration incentives. However, new ventures with more competitive resources are less likely to create slack in the internationalization process, therefore they can make efficient investments to develop dynamic capabilities for long term development. Zhou and Wu (2010) argued that absorptive capacity built on technological resources can predict both the exploitation and exploration of new products in different ways. Therefore resource advantages, rather than slack resources, drive the development of ambidextrous capability. Built on this notion, I argue that an early internationalization with the stronger late exploitation capabilities is associated with resource advantages, such as knowledge ownership. This approach implies that a new venture can achieve rapid growth by holding resource ownership and by enhancing its competitive advantage using incremental exploitation after a burst of exploration. 
Information Availability. Information has played the key role in explaining the internationalization process of new ventures. According to the entrepreneurship literature, the discovery of new opportunities is associated with information about new and innovative solutions. And information also provides new ventures with insights about how to imitate actions that have already been pioneered or adopted by others. Therefore, the discovery of opportunities for exploitation takes place in a disequilibrium setting. And the asymmetrical information and unanticipated changes are caused by incomplete information and uncertainty (Matthew and Zander, 2007), which means that international boundaries are also determined by the information available to new ventures.

Liesch and Knight (1999) used the hurdle rates perspective to explain "what is the role of information in SME internationalization and how might SMEs recognize when to pursue a particular internationalization project". The theoretical framework from their study provides insight on the impact of information on the internationalization process, which provides a consistent argument and robust theoretical discussion with regard to the gradual model, which explained the traditional internationalization process.

Further, in the ambidexterity literature, March (1991) pointed out that search behaviors are inhibited if the most preferred alternative appears because firms make decisions with bounded rationality, which is determined by the information available to the firm. And, search behavior is stimulated when the most preferred known alternatives are likely to produce outcomes below the objectives. Thus, the more information which is dispersed in an asymmetric way and in an uncertain environment, the more likely new ventures are to choose exploitation over exploration. This argument has been used to explain how to build ambidexterity through organizational structures (March, 1991). Fang, Lee and Schilling (2010) argue that firms need to 
invest in semi-isolated subgroups in order to facilitate information availability in an efficient manner in order to achieve a balance of exploitation and exploration.

Therefore, in order to achieve international ambidexterity, new ventures may invest in information flow in multiple locations, including both home and host countries, thus they can develop an early international exploration strategy, followed by more efficient approaches, such as international exploitation for a long term performance.

Managerial Mindset. The managerial mindset of managers is another aspect used to explain the choice between exploitation and exploration.

The entrepreneurship literature (Shane, 2000) discusses how the entrepreneurial orientation regarding opportunity identification and risk-driven behaviors can explain a firm's strategy. Entrepreneurs are expected to discover opportunities that are directly related to their cognitive knowledge base.

The international entrepreneur's knowledge regarding the market, the customer and the ways of service will affect the opportunity they may identify in a broader market (Freeman and Cavusgil, 2007). Therefore, entrepreneurs, who have the breadth of prior knowledge, as well as the variety of linkages across prior knowledge, are better able to prepare for taking on exploitation tasks in foreign markets. For example, one founder of new venture may have work experience in different countries, but he or she may not be able to have the whole picture of how to find the optimal location choice by comparing the linkage of these countries. Therefore this entrepreneur may only pursue exploration by seeking opportunities in multiple countries.

In the literature review, I referred to the current studies focusing on cognitive and behavioral insights to understand how managerial resources can achieve superior performance through exploitation and exploration (Benner and Tushmann, 2004). The mindset determines 
how the founders perceive the available information and make their judgments accordingly.

Senior managers are responsible for creating a context to facilitate a balance of exploitation and exploration. Zahra et al. (2005) pointed out that how companies craft internationalization strategies is determined by the international orientations of their managers.

Thus, I argue that the focus of the manager's mindset is also a key driver for capability development. And the broader managerial mindset further explains whether some firms will stay in the traditional trajectory to exploit existing or closer opportunities while others make changes from the existing competence to search for more alternatives in the international market.

International experiential knowledge. Firms are required to have a certain level of international knowledge in order to operate internationally as well as to negotiate and transact business with foreign firms across country boundaries (Barkema \& Vermeulen, 1998). Those new ventures which have not developed the international knowledge tend to perceive lower risks. Only as international experience increases would international new ventures engage in high commitment entry to international markets. Meanwhile, having more knowledge about certain locations will increase of the likelihood of the firms exploiting ownership advantages in a few countries; in turn, this same high level of country-specific knowledge increases the possibility that new ventures will pursue an incremental process of internationalization.

When following an exploration strategy, new ventures accumulate their international knowledge about markets, customers and cultural aspects in order to seek and identify opportunities for developing exploitative capabilities. In both contexts, international experiential knowledge helps new ventures make the optimal decision for location choice. Therefore international experiential knowledge will help new ventures develop international exploration at an early stage while supporting their further exploitation at a later stage. 
First, international experiential knowledge can be developed from their international activities. Given the fact that new ventures have not invested in foreign markets to a large extent, their international knowledge can be developed from the founding management team and be learnt from partnerships or institutions in their domestic country at an early stage. For example, international knowledge can be accrued from the founders' previous experiences in multiple foreign markets. In the entrepreneurship literature (Shane, 2000), entrepreneurs are considered to discover opportunities that were directly related to their particular knowledge bases. Cohen and Levinthal (1990) argued that individuals need prior related knowledge to assimilate and use new knowledge.

I argue that international experiential knowledge is formed through the interaction of interrelated individuals in the founding team. Gibson and Birkinshaw (2004) argued that some managers simultaneously engage in exploitation and exploration, thus individuals are indeed the most important sources for developing organizational ambidexterity. According to Tushman and O'Reilly (1996), organizational ambidexterity is not the simple sum of personal ambidexterity. They found that a small number of ambidextrous managers can work together to integrate exploitative and explorative outcomes in different parts of organizational development. The founding team of international new ventures should actively engage in learning through different forms of international knowledge. Such a learning ability is determined by the absorptive capacity built upon individual international knowledge. In addition to the formal training, the ability to learn from their previous experiences in the workplace is also the key for further contributions of the founders to the new ventures. Cross-cultural training and social training with foreign customers, suppliers, and tradeshow specialists can all be considered as special international knowledge for the founders of the international new ventures. And these 
experiences form new ventures' managers' international mindsets and can explain how managers filter and integrate information from external sources.

A firm's foreign expansion decision can be considered in the context of interorganizational learning dynamics among firms (Henisz \& Delios, 2001). If new ventures are exposed to more international knowledge from the environment, they are more likely to absorb the information related to international business opportunities, thus they are more likely to search for, and experiment with, international opportunities in certain specific locations during their initial stage of internationalization. And they can exploit the international business knowledge in their domestic country without exploring by building physical establishments in foreign countries. Moreover, international knowledge will increase new ventures' exploitative incentives to seek preferred solutions for internationalization. However, for those new ventures with strong resources advantages, once new ventures choose the location where they want to exploit existing technological knowledge, they have more alternatives and higher absorptive capacity to integrate knowledge in certain foreign countries. In addition, international knowledge reflects the ability of new ventures to operate in multiple markets and to be able to compare across markets in order to find an optimal location for further exploitation. International knowledge will stimulate their entrepreneurship orientation later on, whenever there is a switch opportunity between exploitation and exploration.

\subsubsection{Summary of drivers to international ambidexterity}

Consistent with the criteria for defining international new ventures proposed by Oviatt \& McDougall's (1994), I conceptualize how new ventures build international ambidexterity as follows: the exploitation approach is determined by the nature and value of new ventures' resources as well as the information availability for identifying alternatives and the focus of the 
managers' mindset; the exploration approach is determined by the position of valuable resources, the information availability for opportunities and the global mindset developed by the managers of new ventures. Barriers or facilitators to international ambidexterity can be manifested in any or all of these factors.

Moreover, these new ventures, which may have a management team with broad prior international knowledge, as well as the variety of linkages across prior knowledge, are better prepared for undertaking exploitation tasks in foreign markets. Resources can be effectively allocated between domestic and foreign countries. An international entrepreneur's knowledge regarding the market, the customers and the ways of service will affect the opportunities they may identify in a broader market (Freeman and Cavusgil, 2007). ${ }^{1}$

In the next section, I build my hypotheses based on the conceptual framework regarding drivers to international ambidexterity. I bridge intra-organizational learning through technological integrated knowledge, and inter-organizational learning (including, dyadic relational knowledge and environmental knowledge) with the concept of international ambidexterity. Additionally, the relationship is explained through the drivers to international ambidexterity. Thus, my model provides a comprehensive view to help us understand how

\footnotetext{
${ }^{1}$ In order to better build the conceptual model, I conducted a case study of four international new ventures illustrates the results which inspire the arguments about the drivers to international ambidexterity. More details are included in the Appendix D. According to Table 3 in Chapter 3, I categorize these four firms into international exploitation, international exploration and international ambidexterity. Four new ventures in the high technology dot.com industry emphasize the importance of technology development and technology property. However, two firms didn't pursue early international exploration, identified as international exploitation companies, and specifically emphasized the importance of integrated technology from different domains. This supports the argument that integrated technological knowledge is associated with further international exploitation. Three firms state the importance of alliances for their development and the international new venture, which has broader scope of international expansion after its IPO, also stated their concerns of partnership for further development. This is complementary to the argument that international ambidexterity capabilities are associated with alliances, but not in a linear manner. All four companies emphasize the importance of their managerial groups for the growth, especially two firms pursuing early international exploration focus on the structure of their founding groups rather than one single decision maker's background. This indicates that the managerial resources and previous experiences of founding teams are important to balancing both exploitation and exploration activities. The results of my study provided a foundation for developing the hypotheses for further quantitative analyses.
} 
internal factors interact with external ones to drive the internationalization process of new ventures.

\subsection{Hypotheses development}

In the following section, I categorize the variables for hypotheses development into new venture technological knowledge, relational knowledge exchanges and local knowledge dynamics in order to determine the likelihood of new ventures choosing international exploitation, international exploration or developing international ambidexterity. According to my literature review in Chapter 2, there has been an increasing trend of using the knowledgebased view in the international management literature. Dunning(1998) pointed out that value added activities have become increasingly knowledge-intensive, not just in high technology sectors, but also in those industries that were previously regarded as natural resources-based or labor-intensive. In addition, knowledge creation and knowledge transfer capabilities are directly associated with the three drivers (resource advantages, information availability and managerial mindset) to exploitation and exploration activities. Such a process helps new ventures further generate knowledge.

Built on the notions I develop in section 3.1, such as resource advantages, information availability, managerial mindset and international experiential knowledge, I focus on understanding how internal knowledge structures and external knowledge sources can help new ventures develop international ambidexterity. More specifically, the knowledge structure can determine the time, the location, as well as the breadth and depth of the international expansion of new ventures. This model also provides some implications about how new ventures can make intended investments to pursue early internationalization as well as to select a narrower scope of international expansion and closer locations for international expansion and further growth. 
As shown below, seven hypotheses were formulated. Hypothesis 1 is the hypothesis testing the relationship between internal knowledge structure and international ambidexterity. Hypotheses 2 and 3 are used for testing the direct and indirect effects of having alliances on developing international ambidextrous capability in new ventures. Hypotheses 4 and 5 are used for testing the direct and indirect effects of the geographic cluster. Hypotheses 6 and 7 are used to test the research question "Do those new ventures which develop international ambidextrous capability accelerate their growth faster than those without this capability?"

For more details, please refer to Figure 3, which illustrates the hypotheses model of my study $^{2}$.

Figure 3 Empirical model for hypotheses testing

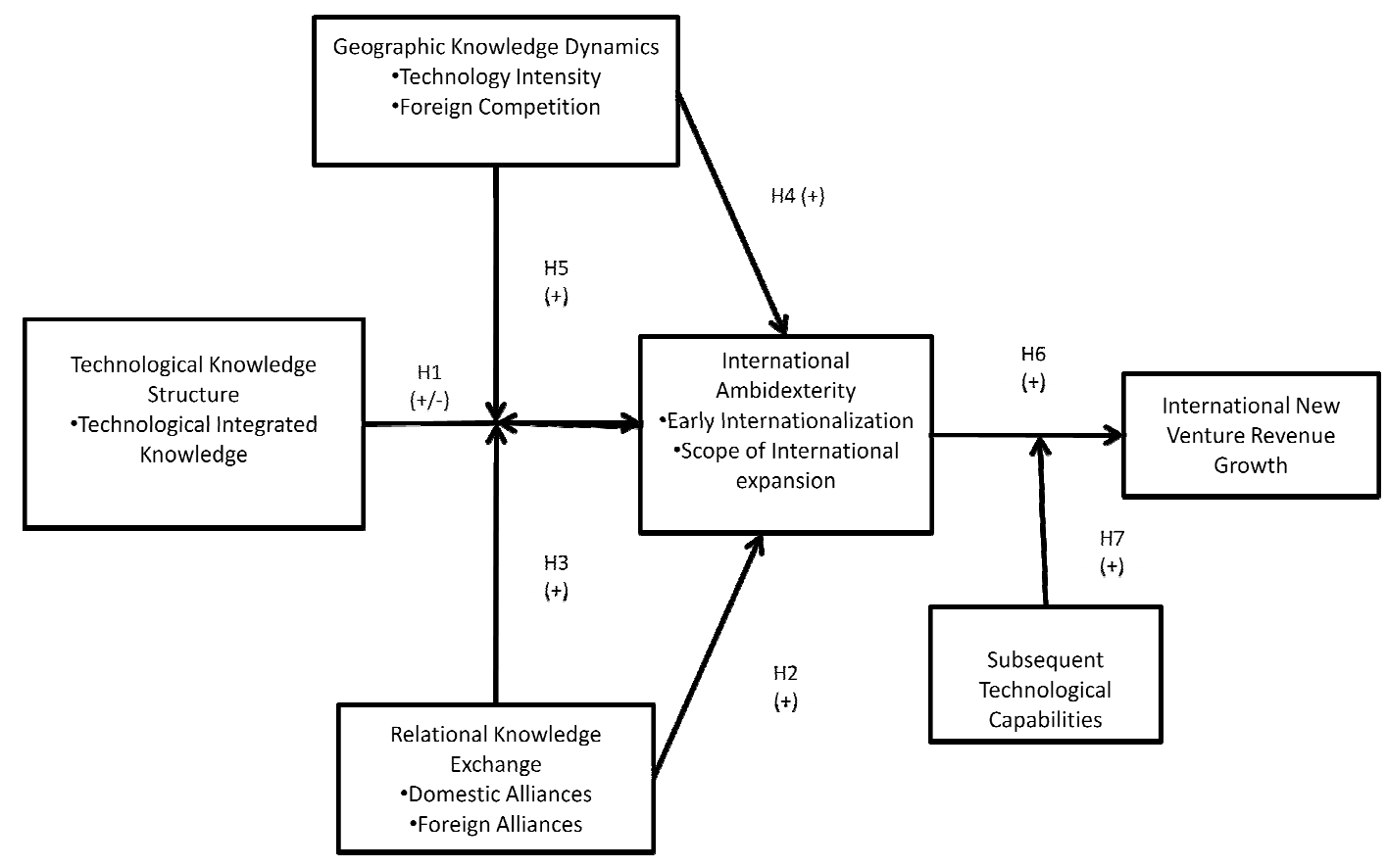

\footnotetext{
${ }^{2}$ Bullet point represents variables in the hypotheses.
} 


\subsubsection{Technological knowledge structure}

Tallman and Fladmoe-Lindquist (2002) referred to the notions of component knowledge and architectural knowledge to define firms' competence. Component knowledge includes scientific, technical, engineering and design skills in technology-oriented industries. Component knowledge in consumer industries includes knowledge of consumer behavior, marketing, sales, promotion and so forth. "For example, the motion picture industry would require knowledge of production, direction, cinematography, acting, and many other technical aspects of film making" (Tallman et al. 2004). The concept of component knowledge resides largely at the industry level. Therefore, firms in the same industry are likely to share a large overlap in component knowledge.

In addition, component knowledge is tied normally to the industry characteristics, such as the natural or societal phenomena, rather than personnel or organizational attributes. Component knowledge can be transferred to other organizations which have absorptive capacity. New ventures which possess strong component knowledge may seek internationalization to exploit their existing knowledge asset by integrating more component knowledge. However, they lack specific knowledge advantages built within their domestic country and they often don't have sufficient safeguards to protect knowledge spillovers in foreign countries. Therefore, they may not be able to benefit from subsequent international exploitation although new ventures can incorporate transferrable knowledge from other entities. Moreover, whether international new ventures can benefit from such an exploitation approach is dependent upon the distance between the domestic country and the countries of which they already have some degree of prior knowledge. 
This argument provides implications about how to reproduce the patterns of multiple location expansions. Once new ventures, which possess more component knowledge without integration, go international, they are more likely to grow into different locations with a broader scope for further growth. Technological component knowledge possessed by new ventures will be curvilinearly related to the likelihood they are to develop an international ambidextrous capability, such that new ventures with higher or lower levels of component knowledge will be less likely to develop an international ambidextrous capability relative to those with moderate knowledge for integration.

On the other hand, when component knowledge achieves a certain level, firms integrate knowledge from different domains to achieve an integrated knowledge base. And integrated technological knowledge refers to a broader understanding of how the components are brought together. This is consistent with the notion of architectural knowledge. For instance, architectural knowledge includes the knowledge about who is whom and how firms are connected, as well as the understanding of institutional influences and the importance of local embeddedness. As Saxenian (1994) noted, the cultural and technical terminology and the work practices are largely idiosyncratic to each region. Therefore, architectural knowledge is more systemic and complex than component knowledge and is not codified. At the firm level, architectural knowledge refers to the accumulated knowledge that embodies the capability to manage global operations. These operations include knowing how to explore or exploit existing capabilities across technologies, businesses and geographies.

Each new venture can develop its internal knowledge structure built on its component knowledge and achieve an integrated technological knowledge. The knowledge structure can shape processes for organizational learning through international exploitation and exploration. It 
can also create the managerial cognition processes for the firm to achieve ambidexterity. New ventures can continue enhancing such ambidexterity, based on both component knowledge and architectural knowledge for further growth. Through developing an ambidextrous capability, new ventures can leverage their existing integrated knowledge base to new markets and industries. While exploiting, new ventures make use of their knowledge advantages. While exploring, new ventures seek business or location-related knowledge which departs from their existing knowledge structure.

New ventures which possess higher levels of the component knowledge may face more alternatives, including business opportunities in foreign countries. However, the nature of knowledge also creates disadvantages. For instance, new ventures are less likely to create unique resources for them to compete with other firms from the same country. And the dispersed information about their technology can be better absorbed by other firms. Although more alternatives may emerge, no preferred alternative will appear. Because the firm exploitation decision is built on the preferred alternative, new ventures with higher levels of technological component knowledge are less likely to build an international exploitation capability. Therefore, new ventures with higher levels of component knowledge are less likely to continue building knowledge advantages after an early international exploration. Given these points, the more technological component knowledge possessed by new ventures, the less likely they are to develop an international exploitation capability and the less likely they are to develop an international ambidextrous capability.

For new ventures which possess higher levels of technological integrated knowledge, technological integrated knowledge is built on component knowledge. International new ventures expand and compete through their architectural knowledge by integrating component 
knowledge. The capability of integrating knowledge is built from the entire pool of prior experiences and it provides potential value for knowledge ownership advantages. The technological integrated knowledge serves as the unique resource for international new ventures. New ventures with more experience operating in different technology domains have strong skills already accrued from their domestic experience. They are also able to implement relevant culture, norms and values into the technology design. Therefore, the more integrated knowledge a new venture has, the more likely it will be to benefit from further exploitation in a familiar environment.

HIa: Technological integrated knowledge possessed by new ventures has a curvilinear relationship (Inverted U-shape) with the likelihood that they go international at the early stage. H1b: The more technological integrated knowledge possessed by new ventures, the narrower the scope of their subsequent international expansion.

\subsubsection{Relational knowledge exchange}

New ventures usually face two types of pressure during their international expansion. The first is internal, as I stated in the previous section, knowledge structure impacts new venture capability to acquire, integrate and disseminate knowledge in foreign countries. The second type of pressure is evidenced from the external environment and the new venture's relationships with partners. To access external knowledge, new ventures need to establish relational structures built on the local environment or the relational context to access a broad set of resources, as well as to seek and evaluate the available information and develop the focus of a global mindset. Researchers have found that inter-organizational activities can enable both exploitation and exploration of the knowledge creation processes (Raisch et al. 2009). In certain contexts, the external source may have more impact on building an ambidextrous capability. For example, Rosenkoph and Nerkar (2001) found empirical evidence that exploration through alliances had 
more impact than exploration within organizations. Therefore, I also investigate the external factors that impact the development of international ambidexterity for new ventures.

In this section, I investigate more about how alliances' relationships are associated with the internationalization process of new ventures. Compared to large corporations, new ventures lack sufficient resources, thus they are more likely to seek external sources to acquire resources and information. Thereby, they create formal and informal knowledge ties for further growth. Hamel, Doz and Prahalad (1989) argued that alliance partners exchange knowledge through both formal and informal communication channels.

Alliance partners provide powerful organizational arrangements and keep new ventures competitive (Baum, Calabrese, and Silverman, 2000). The rapidly changing environment has made firms vulnerable to failure, thus has increased their needs to enter alliances (Stuart, 2000). New ventures tend to have a high propensity to collaborate with others. As new ventures develop alliance relationships, they increase the pool of resources and the ability of firms to enhance their competitive advantages in internationalization (Oviatt and McDougall, 2005).

Inkpen (2005) suggested that the differences in partners' skills and knowledge are the main determinants of inter-organizational learning. Thus, a likely determinant of ties is repeated interaction, which can be used to form a basis of commitment, trust and identity for knowledge transfer between units (Kostova \& Roth, 2003; Nahapiet \& Ghoshal, 1998). Repeated interaction can also explain the potential efforts of the international new ventures to absorb knowledge when "stickiness" is high (Szulanski, 1996). Social ties further contribute to organizational learning by smoothing the interface among effective parties, enabling open dialogue and questioning the private and fine-grained information shared through trusted channels (Uzzi, 1997). These ties are also characterized by relationship-specific heuristics that 
can facilitate the exchange and processes of tacit and system-dependent knowledge sharing between the participants (Hansen, 1999; Tsai, 2002), therefore influence managerial mindset for exploitation and exploration.

\subsubsection{Domestic knowledge ties}

New ventures' internal knowledge may be not sufficient and can be very costly for internationalization, thus entrepreneurs often seek external ties with others. This learning is largely dependent upon the mechanisms that give access to, or generate exposure to, the resources of information. And such mechanisms also include the knowledge transfer from others, including networks and alliance partners.

First, a new venture can be related by multiple ties in its domestic network, thus it can occupy a strategic position in the global network through involvement in many significant ties. As a result, it can enjoy the greater status and easier access to resources and knowledge of the network members. When choosing a potential partner, the focal new venture is likely to seek a domestic partner that is highly central in the network because the new venture lacks resources but possesses entrepreneurial orientation, while a central firm in the network is more likely to have more resources. The high centrality of a partner means that the focal new venture will have easier, more direct access to more resources and the knowledge of that partner through knowledge transfer (Gnyawali and Madhavan, 2001; Powell, Koput, and Smith-Doerr, 1996). This may decrease the incentive of new ventures to seek opportunities in foreign markets at an early stage.

Second, building more social ties in the domestic country implies that new ventures have a higher status and level of power. When new ventures get connected to more partners in the network, their status as a focal firm is likely to be elevated. This status can help them overcome 
problems stemming from the liability of newness. Thus, once it goes abroad, the new venture can support its pursuit of further opportunities in more countries. The improved status of the firm in its network is likely to increase the influence of the focal new venture on decisionmaking, resource allocation, and the entrepreneurial championing (Floyd, 1999).

Third, weak ties give new ventures access to greater information with novelty and diversity than strong ties do. While strong ties enable international new ventures to share sensitive information and valuable resources in their domestic markets, weak ties have been associated with explicit knowledge transfer. Strong ties are more likely to help organizations gain tacit knowledge. Therefore, if a new venture has more strong ties in its domestic country, it is more likely to get tacit knowledge spillovers. Then, the knowledge spillover distracts the new venture from gaining more knowledge from international markets. Such tacit knowledge is not easily transferred across institutions (Kostova, 1999; Kostova and Roth, 2003). However, international entrepreneurs are required to gain legitimacy in their domestic country and face more pressure than when gaining legitimacy in foreign countries (given that both international new ventures and large MNCs face pressure to gain legitimacy because of foreignness). Thus, if entrepreneurs have more weak ties in their domestic country, their information is less tacit.

In addition to their direct effect, alliances can also interact with firm technological resources to develop an international ambidexterity. Alliance formation may be determined by new ventures' resources. In partnership building, financial resources, prior alliance experiences and technological resources would make a new venture valuable for other partners. New ventures may have insufficient financial resources and prior alliances, thus technological resources are the key for other alliance partners to choose cooperation. Therefore, new ventures who have more domestic alliance partners are the ones who have the basic capability to exploit existing 
knowledge. It is also likely that their partnerships have helped them with allocating resources in the domestic market rather than foreign markets. However, those firms without certain attraction to domestic partners may choose exploring international markets for acquiring resources and market, thus they may go international at the early stage but are less likely to build an exploitation path afterwards.

H2a: the more domestic alliances participated in by new ventures, the less likely new ventures are to go international at the early stage.

$H 2 b$ : the more domestic alliances participated in by new ventures, the narrower the scope new ventures are likely to develop for subsequent international expansion.

\subsubsection{Foreign knowledge ties}

Network learning benefits focal new ventures while direct learning from foreign partners can be another source of benefits. First, the foreign cooperation experienced in the domestic country leads to the creation of new knowledge, especially experiential knowledge from engaging in foreign operations. Such new knowledge may assist new ventures to build absorptive capacities in order to seek and identify opportunities in the global market (Agarwal, Echambadi, Franco, and Sarkar, 2004; Delios and Beamish, 2001). In addition, foreign MNCs who choose partnerships as their preferred entry mode with local new ventures usually seek complementary resources. If these foreign MNCs have sufficient technological knowledge, they seek market partners. Thus they may be less likely to choose local new ventures who have not built a strong market base yet. Some foreign MNCs may seek complementary technological resources from local partners. In this case, a more balanced relationship between foreign partners and local new ventures is established. In other words, if the focal new venture's knowledge base is low, the foreign alliance partners are more likely to choose the new venture for the purpose of building market legitimacy. 
Those new ventures with which other foreign partners seek cooperation, are more likely to absorb technical knowledge in their domestic countries; therefore they can build a strong technological knowledge base. These new ventures are more likely to adopt exploitative learning approaches for entering into other countries. Meanwhile, given the strong knowledge base, these new ventures are more likely to conduct knowledge exploration. They created different types of capabilities during the process of learning from their foreign partners. In order to compete, new ventures are more likely to be exposed to new management techniques and strategies brought from the foreign partners, possibly lowering the uncertainty of the internationalization decision. Once they grow further, these new ventures may have a strong knowledge base to serve the exploitation capability along with their entrepreneurial orientation.

Second, for these international new ventures which engage in a broader knowledge transfer network, their previous experiences also provide them with strong capabilities to manage their foreign operations and to learn in global markets. Strategic alliances and cooperative ventures represent powerful organizational arrangements that facilitate the process of learning and knowledge acquisition. Through network learning, companies may acquire the knowledge required for their foreign expansion by actively engaging in knowledge-sharing networks. And such networks provide a benefit of knowledge transfer that affects the stock of knowledge available to the firm. In addition, legitimacy plays a role in a global network as well. A firm's ability to penetrate a foreign market might be limited by regulation, marketing experience and reputation. Therefore, early engagement in an international network through domestic ties with foreign partners would provide new ventures with the alternatives to judge the preferred returns for further entries. Thus, they may be less likely to choose risky exploratory behaviors after early internationalization. 
Third, early access to international information flows increases the possibility of the focal new venture contributing knowledge and other resources to the partner. Through mutual knowledge interaction, international new ventures are more likely to create valuable knowledge for further growth. However, mutual learning requires new ventures' absorptive capacity. And effective relationships will help international new ventures to develop technical expertise and combine this expertise into their knowledge base. Further, reciprocity as well as common goals and goodwill (Yli-Renko, Autio, and Sapirnza, 2001) between the connected partners will facilitate more tacit knowledge development, which necessitates social relationships. Compared to new ventures that possess strong technological capabilities, new ventures with low technology partnerships may have more marketing knowledge to attract foreign partners; however, marketing knowledge based alliances involve more contextual knowledge. This type of knowledge is considered as knowledge about an organizational location and its environment, which means that this knowledge is specifically locally oriented and collocated people share the same contextual knowledge while people in different locations have different contextual knowledge.

Firms are required to have certain levels of international knowledge in order to operate internationally as well as to negotiate and transact business with foreign firms across country boundaries. Those new ventures which have not developed integrated knowledge tend to perceive lower risks. Only as international experience increases would international new ventures engage in high commitment entry to international markets. Especially, the new ventures which possess strong technological integrated knowledge need international component knowledge to achieve a spurt of exploration, given their existing capabilities. Meanwhile, more knowledge about certain locations will increase the likelihood of the firms exploiting ownership 
advantages in a few countries; in turn, it increases the possibility that new ventures pursue an incremental process of internationalization.

H3a: The relationship between the technological integrated knowledge and the likelihood of new ventures to go international at the early stage is positively moderated by their foreign alliance partnerships.

$H 3 b$ : The relationship between the technological integrated knowledge and the scope of the subsequent international expansion is positively moderated by their foreign alliance partnerships.

\subsubsection{Geographic knowledge dynamics}

The term "Geographic cluster" has been used to refer to clustering phenomena, such as geographic agglomeration (Audretsch and Feldman, 1996; Bell, 2005; Rosenthal and Strange, 2003). It often refers to a geographically constrained region with the clustering of industries. A cluster is characterized by the dependency of firms on natural or intangible resources from the location. Therefore, within clusters, new ventures are often founded to fulfill specific components of the production process. Also, cluster locations often become environments comprised of highly skilled labor, industry knowledge and a supportive social structure conducive to an entrepreneur-friendly environment.

\subsubsection{Technology intensity at geographic location}

Technology intensity is defined as the extent to which research and development are important for firms in a geographic cluster. Locations with high technology intensity typically highly invest in R\&D; the renewal of the technological foundation is likely to be frequent. Due to the importance of knowledge in these locations, I argue that new ventures from these locations with high technology are more likely to benefit from further growth.

First, locations with high technology intensity require high levels of innovation collaboration that can be facilitated by the firms. Firms in these clusters innovate more than 
geographically isolated firms (Baptist \& Swann, 1998; Feldman, 1994). Thus, they are more likely to build a unique resource for further exploitation. Moreover, high technology complexity can result in the agglomeration of R\&D (Carrinacazeaux, Lung, and Rallet, 2001). High technology complexity requires a high frequency of renewal of the knowledge base, as well as the strong combination of different types of knowledge. Geographic proximity promotes the repeated interaction and mutual trust needed to sustain collaboration and to speed the continual recombination of technology and skill (Porter, 1998; Saxenian, 1994). Thus new ventures born in those locations may build a strong capability for renewing their existing competencies. Once they go abroad, the new ventures may revise their capabilities and balance their capabilities between the domestic market and foreign expansion.

Second, geographic clusters facilitate knowledge spillovers that benefit new ventures with high technology intensity. Local information flows locally more easily than over greater distances (Marshall, 1920; Saxenian, 1994). For example, patent citations tend to occur more frequently within the state in which they were patented than outside of that state (Jaffe, Trajtenberg, \& Henderson, 1993). Francis, Zheng and Mukherji (2009) used country, industry and firm level factors to categorize mimetic behaviors of firm's decisions. In their theoretical model, given that mimicry takes place in the face of uncertainty, firms need to search for familiar alternatives and seek to economize search costs. Levitt and March (1988) argued that firms tend to approach legitimacy-related imitation to gain competitive mimicry. Consistent with the study by DiMaggio and Powell (1983), Levitt and March argued that organizations tend to imitate actions taken by a large number of socially proximate organizations (size, sector or region) because of perceived legitimacy. Therefore, new ventures embedded in technology intense 
locations tend to identify opportunities easily but imitate large MNCs' internationalization approaches to neutralize uncertainty, thus they form their international ambidextrous capability.

Third, new ventures in the locations with high technology intensity face high technological uncertainty. They may use the cluster to develop a local mindset to facilitate the exploitation of technologies or the institutionalization of industry standards. When technological uncertainty is high, choosing the future dominant design ensures survival for firms. Institutionalization processes provide a pattern of conformity, from which firms can set up the dominant designs to their own advantage. The pattern of conformity arises through mimic isomorphism (Dimaggio \& Powell, 1983), or through action trajectories produced by compromise conventions, rules, practices, and institutions (Tallman et al., 2004). Thus new ventures from such a cluster will be more institutionalized. Geographic proximity, and therefore information channels, facilitates the formation of the pattern of conformity.

H4a: the higher the technology intensity in the geographic cluster where new ventures are located, the more likely new ventures are to go international at the early stage.

$H 4 b$ : the higher the technology intensity in the geographic cluster where new ventures are located, the more likely the new ventures are to develop a narrower scope of the subsequent international expansion.

\subsubsection{Foreign competition at the geographic location}

Competition at the cluster level allows the focal firms to produce products at lower cost or differentiate their products more effectively because clusters provide the opportunities to develop industry-specialized factors of production, such as equipment or organizational routines. Moreover, competition also increases the interdependence between the focal new ventures and the complementary partners, such as those from downstream or upstream industries. In addition, positive and negative relationships among firms within a global network can enhance or hamper firms' abilities to absorb the inflow of knowledge from new entries (Argote, 1999). Therefore, I 
argue that an understanding of learning in different cooperative and competitive relationships is essential for both MNCs and international new ventures. I argue that high competition from foreign MNCs at the cluster level will increase the likelihood that new ventures develop an international ambidextrous capability through resources allocation, international information identification and global mindset building.

First, the competitive relationship can directly reflect the relationship quality and density between a focal international new venture and its existing counterparts. Further, the competitive relationship can impact the value of subsequent knowledge transfers between focal international new ventures and other firms. Also, firms in the cluster may face increasing completion from outside firms, both MNCs and other new ventures. As mentioned previously, competition is likely to be dynamic and put pressure on existing relationships. This will stimulate the focal international new ventures to explore opportunities from previous international competitive experiences, since the firm is assumed to be pressured by competition to actively search for new knowledge in order to outperform the competing firms. Therefore, the higher the level of competition between focal international new ventures and their counterparts, the more likely new ventures are to have a motivation to apply additional knowledge from their existing counterparts, rather than searching isolated or new markets.

Second, I argue that the competitive experience with those firms in a global network entails knowledge transfer, which may become a key source of competitive advantage for the international new ventures. Since knowledge is a source of competitive advantage, these practices dealing with foreign competitors may add to firm competitiveness by knowledge transfer, because competition-based experiences share a similar knowledge base in domestic countries. And any transferred knowledge may be used for competition in the future (Tsai, 2002). 
Therefore, the more competition with foreign counterparts the new ventures engage in, the more likely new ventures will be to choose efficient resource allocation strategies for further growth in international markets.

Third, Stuart (2000) argued that low status firms act in order to gain legitimacy from their association with leading firms. And there is organizational mimicry to status, thus new ventures create their chances for survival by mimicking the structures and activities of established leading firms, especially when they are competing for the same resources. In addition, I propose that international learning will be more likely to be successful when new ventures hold a positive mindset about learning from the foreign competitors. Managers of new ventures tend to internationalize at an early stage by following or mimicking other comparable firms in their environments. Therefore, when a new market becomes notably attractive, similar firms are more likely to follow this learning.

However, the mimetic learning requires stronger absorptive capacities of new ventures. The search for new knowledge, and the need to combine it with prior knowledge, is continuous for a new venture, especially in a strongly international institution. Mimetic learning as an outcome of foreign competition is a rational decision model, which is compatible with the experiential learning model. Therefore, for new ventures with stronger technology and an international knowledge base, the success of other firms will decrease their uncertainty and reduce the entrepreneurial incentives of new venture for further exploration behaviors. They are more likely to stay in the existing competence trajectories after going abroad as the first exploration step.

H5a: The relationship between the technological integrated knowledge and the likelihood of new ventures to go international at the early stage is negatively moderated by foreign competition of the geographic cluster. 
H5b: The relationship between the technological integrated knowledge and the scope of the subsequent international expansion is positively moderated by foreign competition of the geographic cluster.

\subsubsection{International ambidexterity and new venture growth}

Literature about dynamic capabilities argues that exploitation and exploration have to be recombined to create value (Eisenhardt and Martin, 2000; Teece, 1997). It is not an easy task for organizations to resolve this tension. This is not saying that new ventures need to maximize both capabilities in order to achieve the optimal value. And I mentioned earlier that the resources of new ventures are scarce, therefore, when they pursue exploring and exploiting resources, the relationship is more likely to be sequential than concurrent. Exploration and exploitation require fundamentally different and inconsistent competencies, thus pursuing both creates a dilemma for new ventures (Benner and Tushman, 2003). I argue that new ventures need to build international ambidexterity as a dynamic capability that goes beyond moving from one competence to the other, but addresses the interaction between the two approaches to create value (Jansen et al. 2009). Further, the manager's task is to balance the time spent between these two approaches in the international expansion process, and the international new venture's dynamic capabilities are enhanced through creating and sustaining such an international ambidexterity.

For those new ventures which can identify the optimal equilibrium for internationalization, competitive advantages emerge to support their further growth. Successful new ventures need an ambidexterity while an imbalance between exploration and exploitation poses threats to firm performance. According to Cao et al. (2009), firms are more likely to be subject to the risk of obsolescence when their magnitude of exploitation exceeds their magnitude of exploration. In their internationalization process, new ventures may risk having a pathdependency problem if they put too much emphasis on exploiting one domain of knowledge. 
Ambidextrous new ventures are required to have an early internationalization to achieve exploration in a highly competitive global market. Therefore, new ventures with an international ambidextrous capability will perform better in the long term than those with an incremental trajectory for internationalization. Given this perspective, the existing competencies can quickly become outdated and further path dependency will slow down the growth process of new ventures.

On the other hand, when new ventures emphasize exploration for international operations too much, they increase the risk of failing to appropriate returns from their experimental activities. Therefore, firms need a balance between the two types of activities for long-term performance. Contrary to a competitive view between exploitation and exploration, the complementary view proposed by Gupta et al. (2006) demonstrated that punctuated equilibrium or temporal evolution between a long period of accumulative exploitation and short bursts of exploration is beneficial. Building on this notion, I argue that new ventures may use sequential adjustments to shift between exploration and exploitation. And the positive effects of exploitation can be drawn on for exploration, and a higher exploitative effect can also improve a firm's effectiveness in exploring new knowledge and in developing capabilities to gain competitive advantages in new markets (Cao et al. 2009). Once a new venture initiates new market entries, repeated use of existing knowledge can make the manager become more aware of current knowledge and have a deeper understanding of current opportunities (Zahra et al. 2000).

In the international entrepreneurship literature, McDougall and Oviatt (1996) discovered that new ventures are more committed to internationalization and grow more, with respect to their market share, than traditional MNCs. Autio et al. (2000) argued that high potential new ventures should internationalize and leverage their learning advantages of newness and exploit 
foreign markets for further growth. Therefore, stronger exploitation through incremental entries will help new ventures to explore their early internationalization benefits. Thus, early internationalization can be complementary with a later exploitative learning by new ventures.

H6a: New ventures pursuing early internationalization are more likely to grow than those pursuing only late internationalization.

H6b: The narrower the subsequent scope of international expansion, the new ventures pursuing early internationalization are more likely to grow.

\subsubsection{Technology capability as a moderator for International Ambidexterity and new}

\section{venture growth}

Previously, I argued that international ambidexterity will impact new ventures' further growth, which is interpreted as early internationalization with subsequent exploitation of international operations. This process is positively associated with the further growth of new ventures. However, throughout their development, new ventures which possess different sets of tangible and intangible resources may change their platform to acquire and integrate resource bundles for growth. Therefore, I also propose the moderator effect of technological capabilities on the growth of international new ventures.

In addition to their international market capabilities, new ventures' growth can also be built on their technology capabilities. According to Gupta et al (2006), the premise of the nature for ambidexterity is necessary to understand whether exploitation and exploration are orthogonal or complementary. Given the context of new ventures, their resources are scarce; therefore, when they pursue technological exploring and exploiting of resources, the relationship is more likely to be mutually exclusive. Therefore, within a single domain (technology type or market knowledge), exploration and exploitation will generally be on opposite ends of a continuous scale. However, if the firms exploit in international operations, they can also explore in another 
loosely coupled domain. For example, when new ventures exploit technology to gain knowledge ownership in one country, they can still explore in different international locations. However, they are less likely to explore different technology domains at the same time.

To function effectively in fast changing environments, organizations have to excel in long term performance. While short term performance focuses on competing in the existing market by improving products, long term performance aims at exploring more needs through technological innovation (Benner and Tushman, 2002). Technological new ventures would have a greater ability to assess and assimilate the knowledge received from both domestic and foreign markets, and presumably be able to more accurately assess the potential returns. Furthermore, knowledge assimilated from the international environment would enable new ventures to identify more innovation opportunities for further growth.

Gilbert et al. (2006) pointed out that different resource sets can lead to different growth performance. Some of the new ventures focus on internal product development, enhancement and extension for further growth. Some other new ventures use partnerships to reduce risk and gain access to different technological distribution channels and customer resources in order to achieve growth. Meanwhile, technological new ventures with higher levels of technological capabilities should be able to realize higher levels of performance. New ventures employing advanced technologies in their innovation activities have been argued to have a greater capability to offer products to their existing markets (Siegel, Siegal and MacMillan, 1993). Therefore, technology development during the growth process can interact with international ambidextrous capability to affect new venture growth.

On one hand, for these new ventures which conduct international exploration after their early internationalization, their competitive advantages come from the improvement of their 
existing technological knowledge. Therefore, it requires more investment, demonstrating their commitment to current knowledge development. On the other hand, new ventures with subsequent international exploration face more pressure to absorb knowledge from host countries. Technological capabilities help these ventures develop a strong knowledge base for integrating external knowledge, thus neutralizing the threat to future growth from exploration.

H7a: the relationship between early internationalization and new venture growth is negatively moderated by the subsequent technology capabilities.

$H 7 b$ : the relationship between scope of subsequent international expansion and new venture growth is positively moderated by the subsequent technology capabilities.

\subsection{Summary regarding to conceptualization of International Ambidexterity}

This chapter introduced the concept of international ambidexterity, defined as a balance of international exploitation and international exploration. The notions of resource advantages, information availability, managerial mindset, as well as international experiential knowledge were also introduced as key forces influencing how new ventures develop an international ambidexterity for further growth. The hypotheses built on these notions reflect the argument that the amount of new venture technological integrated knowledge predicts the likelihood that the firm will develop international ambidexterity. And this integrated knowledge, serving as the internal knowledge structure, also interacts with external knowledge sources (alliances and geographic clusters) to affect international ambidexterity. In the next chapter, I review the methodology to test these hypothesized relationships. 


\section{Chapter 4 Methodology}

It is necessary to utilize a large sample of international new ventures to test my hypotheses. Analytical techniques allow for estimation of the impact of knowledge structures and alliance partners, as well as firm geographic locations related to international ambidexterity and growth. This section introduces the complex methodology employed in testing the hypotheses shown in Chapter 3. It begins with a review of the data collection procedures, describes variable operationalization and finally is concluded by reviewing the analytical procedures.

\subsection{Data collection}

For this dissertation, finding an appropriate sample of firms that focus on achieving high growth objectives is very important. Moreover, with this dissertation, I hope to find an effect of the internationalization process on new venture performance, therefore I only focus on new ventures with international operations.

Before collecting data for the large sample, I conducted case studies in order to develop the scheme for data collection and variable development. In the Appendix D, I describe how I did a case study focusing on four companies, including two international exploitation companies, an international exploration company and an international ambidexterity company. Inductive theory development and deductive experimentation and data gathering are the means through which knowledge about phenomena accumulate (Carlson and Hatfield, 2004). Observation from existing studies and qualitative data can lead to the development of theories, from which hypotheses are developed to understand the regularities in the data.

I used a sample of new ventures that undertook an IPO (Initial Public Offerings). IPO firms are considered as the ones to raise the capital needed to finance growth objectives (Jain and 
Kini, 1994). Especially for high-tech start-ups with limited options for raising the substantial amounts of funding necessary to support continued growth, the decision to make an IPO often marks a critical point in the life of a new venture. Therefore, I can confidently presume that my dependent variable- new venture growth is an appropriate objective that IPO firms desired to achieve. IPO firms are also widely accepted as the firms with high success potential and new ventures that undertake an IPO surpass a high hurdle at a young age. Success at the IPO stage has been considered as an indicator of strong performance in the early stage of new ventures (Sorenson and Stuart, 2000). Therefore, it also suggests that their resources were limited before the IPO. By going public, a firm can improve its future access to financial and other types of resources, such as human resources. Those firms which go international before their IPOs satisfy my assumption those new ventures don't have sufficient resources to support internationalization than those which pursue internationalization until they achieve mature stage of their life. Thus, going international at a pre-IPO stage represents the exploratory strategy for new ventures. And after issuing IPOs, firms are more capable of assessing the impact of international location on their success. In addition to these reasons above, IPO firms are an attractive sample in the sense that there are strict disclosure requirements, thus ample information about them is publically available. Finally, publicly held firms have a legal obligation to report financial data and share any information which may affect their performance. Therefore, using IPO ventures makes it possible to collect data on the key variables.

Another consideration is on the selection of the industries from which the ventures would operate. Since I focus on new ventures' knowledge structure for further growth, high technology firms are considered to have great need for exploring and exploiting their existing knowledge for expansion. As this dissertation is designed to assess the impact of knowledge structure on 
international new ventures, I sampled from high technology industries such as semiconductors, software, and information technology. High technology new ventures focus on commercializing new products and making the industry dynamic given the growth of the industry. Therefore these industries produced many new ventures which undertook IPOs between 1998 and 2008.

Data used to test the hypotheses in this study were obtained from several sources. First, from the Thomson Financial Securities Data Corporation Platinum New Issues and VenturExpert databases (SDC data), I used the industry code to search and selected "HIGH-TECH" industries, and the data provide me with 2923 public traded firms by 2008 . The IPO data include IPO year and founding year, thus I can screen out older ventures. IPO firms are not always new ventures, and reported founding dates may be associated with a change in the ownership structure of the focal firm. The Securities Exchange Commission's (SEC) website was used to investigate the founding date for each firm. According to common academic understanding (Baum, Locke and Smith, 2001), I only included those firms which are less than 8 years or exactly 8 years old at the year of their IPO, therefore satisfying the notion of new ventures with a high growth focus. At the age of eight, firms are mature enough in their operations, thus emerging from a new to a mature state. This gives me 1731 new ventures before issuing IPOs. I didn't limit the observation years after IPO since utilization of a short time period is not feasible in this study. It would have resulted in a smaller sample size than desired for analysis. Then I input the list of firms into an excel file in order to merge the data with other sources.

There were 643 new ventures going public between 1998 and 2008. I only included those companies which were originally located in the United States. Therefore, I excluded foreign companies from the data. Due to missing data on several variables for multiple years, 9 firms were excluded. My final sample consisted of 634 firms which issued IPOs from 1998 to 2008. 
This period was chosen because these years yielded the highest number of new ventures in high technology industries. Given that two years of performance data were desired, 2008 was the last year for which data were available prior to the collection of the data for this dissertation.

Second, I relied on Hoover's Handbook of Emerging Companies, Mergent Online, Compustat, Edgar SEC filings and company websites in order to get other information, such as information about alliances, employment, and R\&D investment, to test my hypotheses. In order to identify firms' geographic location, I obtained company addresses from Mergent Online and SEC filings provide their foreign subsidiaries' locations. Mergent Online provides additional information about firms' subsidiaries, in this way I can identify international new ventures as those with at least one subsidiary located a country other than the United States. Therefore my final sample of international new ventures consisted of 311 firms in total. In summary, I have 2913 observations for these firms in my final longitudinal dataset. And geographic location was used to create variables measuring international exploration and international exploitation.

Financial information, including assets, sales, $R \& D$ expenditures and number of employees were obtained from Compustat and supplemented from Hoover's Handbook of Emerging Companies. Information such as business segment is derived from the Mergent Online database in order to create knowledge structure variables. A key problem in conducting empirical research related to technological knowledge is deciding how to measure innovation. A large body of work in management replies on patents to capture firm knowledge base (Hall, Jaff and Trajtenberg, 2005). A patent is the grant of a property right to an inventor. The U.S. Patent and Trademark Office (USPTO) provided archival data about patents. Patent documents provide detailed information across time, such as assignee (owner) and primary technology classes of patents. Although the use of patents involves some limitations, considering that patents may not 
fully represent the technological knowledge of a company, this drawback is less of a concern in high technology industries, especially for new ventures, where patenting is routinely practiced. I used patent classes to capture integrated feature of patented knowledge for each firm in the sample. I used the USPTO and NBER databases to aggregate the data to the firm level.

Third, data on alliances were obtained from SDC data as well. Specifically I used Thomson Financial Security Data Company's alliance database. In this study, I focus on both domestic and international alliances. I collected cumulative alliance data for the period between 1995 and 2007. Although left censoring of the data might be an issue, this may not affect the validity of the results.

Fourth, since I have variables related to the subject firms' domestic locations, and these clusters are identified based on metropolitan statistical areas (MSAs) and MSAs are defined to include counties, I also had to identify the counties in which firms in my sample are located. County and MSA information were provided from the US Census Bureau and the Harvard Cluster Mapping Project.

\subsection{Variable operationalization}

For each of the 311 international new ventures in the sample, a variety of sources have been used to collect the archival data needed in order to construct the database variables. In the following section, the data collection procedures and data sources for each variable are listed in Figure 4. 


\section{Figure 4 Flowchart for data collection}

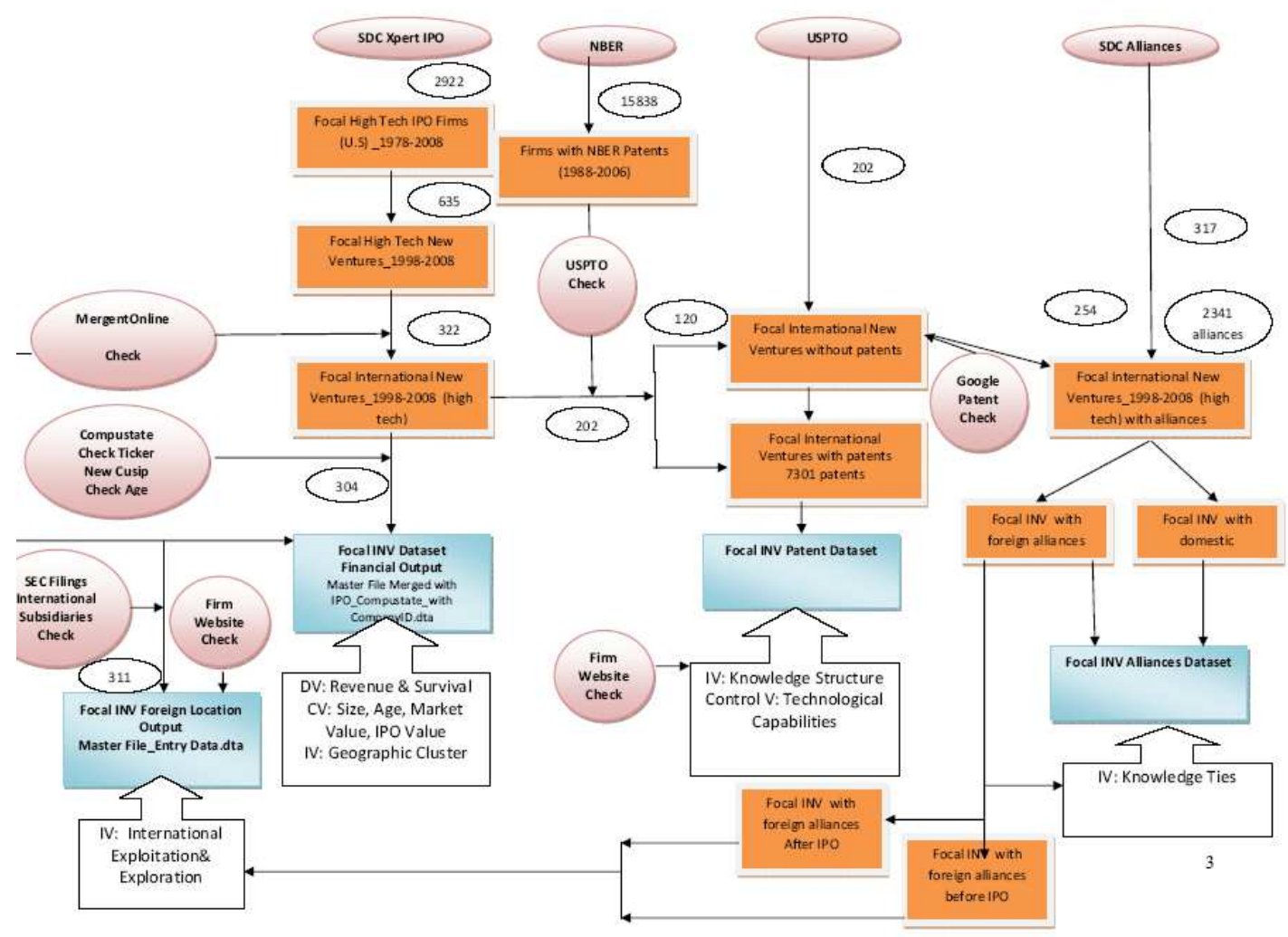

I identified international exploratory, international exploitative and international ambidextrous firms based on my conceptual definitions and categorized each firm based on its internationalization information. In order to code for specific information about internationalization, I combined information from MergentOnline, Mergent Manual, IPO prospectuses (SEC) and Hoover's Handbook of Emerging Companies into a database with firm histories.

\section{International Ambidexterity Identification}

The primary focus of this dissertation is to determine to what extent international new ventures pursue international ambidexterity and whether this pursuit is going to impact firm 
growth. And, if it does, what factors influence the development of international ambidexterity. Two measures of international exploitation, international exploration and international ambidexterity were selected to assess this concept: time and subsidiary location. Internationalization at an early stage was selected because new ventures take high risk and have not developed mature operations for further growth (Sorensen and Stuart, 2000). New ventures are considered to be exploring the international market if they establish their subsidiaries before undertaking an IPO. Location exploration/exploitation is also selected because international expansion through exploration and exploitation may have different impacts on new venture growth, and growth is the important goal for international new ventures. By selecting two measures of the internationalization process, this dissertation contributes to the current literature by developing the concept of ambidexterity with regard to both the time sequence and the balance of operations.

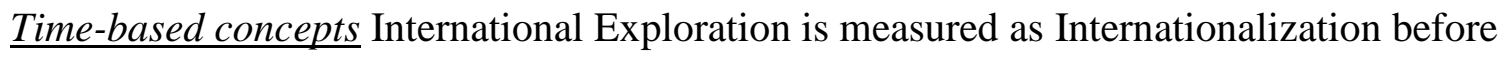
IPO. Using the Mergent Manual of Industries and IPO prospectuses in SEC filings to create the database containing company information and histories, provides me the year of the international expansion of each international new venture before going public. In addition, according to IPO prospectuses, firms would demonstrate whether they have significant international revenues. Here is one statement as an example: "Our international strategy consists of acquiring or entering into foreign countries with existing Internet advertising networks" (SEC prospectus, 1995). The source documents and databases are checked to facilitate appropriate coding of the firms' expanded international operations before they reached the IPO stage as 1; otherwise the coding was 0 , interpreted as later internationalization. 
Location-based concepts The Mergent Manual of Industries also provides me the location of the foreign subsidiaries of new ventures. Thus I could identify their international expansion process. This information was checked with $8 \mathrm{~K}$ and $10 \mathrm{~K}$ reports in the firms' SEC filings as well. Firms would demonstrate whether they have international operations, where firms always state such information: in their most recent $10-\mathrm{K}$ reports, in which they indicate their international revenue in their financial statements. Other keywords, such as international strategy, international operations, foreign operations, and foreign revenues, were used to search each firm's SEC prospectus. Thus I can capture the international activities in each year after the IPO. I used Mergent Online to identify countries of operation for each firm. In this way, I can identify the scope of international operations for each new venture. Institutional Distance was applied in order to capture the notion of subsequent international exploration and international exploitation.

SEC filings require registrant firms to report their subsidiaries annually once IPO firms embark on the IPO stage. In SEC filings, Exhibit 21 specifies stating the registered subsidiary's name and location. This list also includes a breakdown of the percentage of ownership which belongs to the focal new venture. Therefore, I was able to code the entry time, country and subsidiary name for each new entry after the IPO. In addition, I also coded the country, and the name of their foreign subsidiaries before IPO. Thus, I can code both the dummy variable and the value for early stage internationalization.

\subsection{Measures}

\subsubsection{Independent variables}




\section{Knowledge structure of international new ventures. I measured the integrated}

technological knowledge of a new venture using patent data. I operationalized the integrated nature of technological knowledge structure in the following ways:

First, I counted the total number of patents filed by the firm per year, which represents the quantity of the knowledge base. Second, I used primary patent classes to account for the integrative feature of the patent knowledge base. If a new venture integrates knowledge across different patent classes, this new venture has an integrated technological knowledge structure. Therefore, I measured new venture $i$ 's technological knowledge structure at time $\mathrm{t}$ by using a count of the unique three-digit primary technology classes in which a firm filed patents. The variable name is TECHCAT.

I constructed this indicator for those firms that filed at least one patent. When there were no patents filed, this variable shows zero. Results showing the simple count of the number of primary technology classes are reported in the descriptive table 4 .

Alliance Variables. I counted pre-IPO alliances for each new venture. I referred to Thomson Financial Securities Data's Joint Venture and coded those which had alliances with "1" if the firm was shown as the parent company in an alliance deal. I calculated firm i's number of alliances at time $t$ as both the cumulative number of alliances and the number of foreign alliances at time t. And the variable indicating the number of domestic alliances is named DOMALL.

I referred to Thomson Financial Securities Data's Joint Venture and Strategic Alliances database for International Alliances. I also double checked with $8 \mathrm{~K}$ or $10 \mathrm{~K}$ reports in SEC filings and coded "1" for those firms with international alliances such as "In October 1998 we entered into an agreement with China.com Corporation to jointly develop the 24/7 Media Asia 
Network." (SEC), otherwise, the firm was coded "0". And the variable indicating the number of foreign alliances is named FORALL.

Geographic Location variables. In coding Geographic Location I referred to their SEC filing prospectus and coded STATE information by using the two digits of the State Name such as "NJ" for New Jersey. Detailed information about geographic location was measured by using data from the Cluster Mapping Project, developed by the Institute for Strategy and Competitiveness at the Harvard Business School. The Project uses correlation analysis to indentify industries where employment is strongly associated with one another across geographic space. The analyses identified locations at various levels of the U.S, including metropolitan areas and states. Each venture was matched to its metropolitan area using the county associated with the venture's city.

The measure named LOCTECG is used to capture the notion of technology intensity at the geographic location level. According to the Cluster Mapping Project, number of patents was in my study to measure technology intensity. The measure named LOCFORN indicates the foreign direct investment of the location.

\subsubsection{Dependent variables}

\subsubsection{International Exploitation, International Exploration and International}

\section{Ambidexterity}

As mentioned in previous section, Mergent Online is the major source for getting data to measure international exploitation, international exploration and international ambidexterity on both the time and balance dimensions. A new venture was coded as pursuing "international exploration" if information indicates that the new venture's first international subsidiary was established before, or at the same time as, undertaking its IPO, when the first location is one with 
large institutional distance to the US, such as China. A new venture was coded as "international exploitation" if information shows that the new venture's first international subsidiary was established after undertaking the IPO while the first location is in a country with small institutional distance to the US, such as Canada.

Scope of international expansion by using new countries entered by international new venture In order to measure the degree of exploitation/exploration after the IPO, I used the number of new locations including new countries and new continents as well as the scope of international expansion by using the institutional distance of new entries. I relied on March's (1991) approach to capture whether the international country is old or new before the IPO.

The total number of international expansions by the new venture in the two years after its IPO year was counted in order to create a variable for international ambidexterity assigned the variable name: NEWEX. The total number of new countries entered by new ventures was also created with the name NEWLOC, therefore, new ventures with more new country entries are considered as having a higher degree of international exploration, otherwise they are considered to have a higher degree of international exploitation. This is also measured by how many continents firms have operations on following the IPO year. I use the continent, in addition to the countries, so that the similarity among countries within certain areas is not overly taken into account to explain international expansion of new ventures.

Scope of international expansion by using Institutional Distance Both NEWEX and NEWLOC values are taken into calculation together to determine the balance of international operations for International ambidexterity in the analyses. New variable with name NEWID was 
assigned, which represents the scope of subsequent international activities by considering institutional distance ${ }^{3}$.

\subsubsection{International new venture growth}

Growth performance- Sales growth is the most commonly used measure for venture growth (Brush and Vanderwerf, 1992; Murphy, Trailer and Hill, 1996). New ventures grow through increasing their level of sales, thus they are able to increase the odds of survival and reach economies of scale. Therefore, the impact of internationalization on sales growth will provide information for entrepreneurs regarding location choice in global markets. The growth of sales from the year of the IPO to the first year beyond is used and sales data are downloaded from Compustat. For those firms with no available information in Compustat, Mergent Online is used to check the financial data. The LOGREVTGROWTH variable represents the log value of sales growth.

The LOGSIZEGROWTH variable represents the log value of employee growth SURVIVAL: I coded the Survival variable and name it "SURVIVAL" according to both Mergent Online and the SEC filing. If the firm continues operations in 2011 without a previous history of being acquired or of bankruptcy, I coded a "1" to indicate that the firm survives. Otherwise I coded it a "0". I also coded acquisition information from SEC filings. I code those firms which didn't survive with a " 1 " if the firm got acquired, and I coded it a " 0 " otherwise.

\subsubsection{Moderator variables}

Technological Capabilities is measured as the number of new patents introduced to the market (Katila and Ahuja, 2002; Zahra and Nielson, 2002). I named it "PATENTGROWTH".

\footnotetext{
${ }^{3}$ Scope of international expansion has three different measures: number of new countries entered, number of continents where international new venture operates, and institutional distance of all countries entered. And these measures provide high correlation among each other, which support the evidence that three measures are along with the same variable. Given the concept of exploration: experiment and seek new knowledge, therefore, I choose number of new countries entered as the final measure for scope of international expansion.
} 
Given that my sample is from high technology industries such as the software, semiconductor and biotechnology industries, these new ventures enhance their existing product lines and release patents as one of the core activities in their product innovation efforts. Therefore, I coded the number of new patents filed after the IPO as technological capabilities.

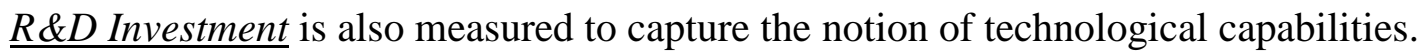

R\&D information is tested as sourced via Compustat North America. And this is taken as Natural Log and named as "LOGRDGROWTH".

\subsubsection{Control variables}

I included firm age, firm size and industry variables in my models as control variables because age and size imply firm resource advantages, which may impact their further revenue growth. In order to exclude the explanation of firm growth as a common industry feature, I controlled for industry as well. In addition, my analysis controls for several other variables that are likely to affect new venture IPO rates. I control for IPO price (natural log), and the IPO firm's first-day stock returns, since under-pricing can reflect uncertainty about the firm.

Firm age. I measured firm age by the number of years that have passed since the founding of the firm to the year of observation. I also included firm age when the IPO is issued as an alternative measure. Age should have an effect on both the rates of issuing IPOs and the rates of internationalization. Firms that have existed for longer periods of time have more learning experience and larger amounts of resources. Older firms involve less uncertainty and less risk than younger ones.

Firm Size. I measured firm size by the number of employees, since previous scholars have indicated that firm size can influence the strategic choices of new ventures and larger firms involve less uncertainty and have greater access to critical resources, therefore, larger firms may 
be perceived as having greater growth. And in my sample firm size includes outliers and is highly right-skewed, so I used the log of the number of employees.

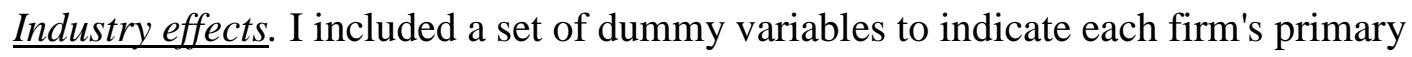
industry section in order to control for growth differences based on the nature of the industry. Industry growth influences the growth a firm can achieve. For example, in an emerging industry, a firm may achieve higher levels of growth rate compared to a mature industry. One of the explanations is that the demand for products may become slow. In my data, I included five different industry sections: Computer related industry, Communication related industry, Semiconductor, Medical and Health sector and Biotechnology sector. This is based on Compustat Primary industry sectors. Therefore I created five industry dummy variables accordingly.

$\underline{I P O}$ year effect. I also included one dummy variable to indicate the year of IPO. The time period before 2000 is known as the time period including an economic bubble. To ensure differences in performance could not be attributed to this effect, dummy variables reflecting the year of IPO were included to indicate wither the new venture issued its IPO before or after 2000.

Table 2 Summary of constructs, variables and measures for hypotheses testing

\begin{tabular}{|c|c|c|c|c|}
\hline $\begin{array}{l}\text { Categories of } \\
\text { Constructs }\end{array}$ & Constructs & Variables & $\begin{array}{l}\text { Name Of } \\
\text { Measures }\end{array}$ & Measures \\
\hline $\begin{array}{l}\text { International } \\
\text { Ambidexterity } \\
\text { of New } \\
\text { Ventures }\end{array}$ & $\begin{array}{l}\text { International } \\
\text { Ambidexterity of } \\
\text { International } \\
\text { New Venture }\end{array}$ & \begin{tabular}{|l|} 
Early \\
Internationalizati \\
on \\
Narrow scope of \\
subsequent \\
international \\
expansion
\end{tabular} & $\begin{array}{l}\text { IETIME } \\
\text { NEWEX } \\
\text { NEWLOC } \\
\text { NEWCON } \\
\text { NEWID }\end{array}$ & $\begin{array}{l}\text { When: IETIME as 1: building foreign } \\
\text { subsidiaries before IPO } \\
\text { Scope of international expansion: NEWLOC: } \\
\text { Number of new countries entered } \\
\text { NEWID: Institutional distance was included } \\
\text {; closeness of early international market: } \\
\text { different location/continent for international } \\
\text { expansion }\end{array}$ \\
\hline
\end{tabular}




\begin{tabular}{|c|c|c|c|c|}
\hline & $\begin{array}{l}\text { New Venture } \\
\text { International } \\
\text { Exploitation }\end{array}$ & \begin{tabular}{|l|} 
Late \\
Internationalizati \\
on \\
Narrow scope of \\
subsequent \\
international \\
expansion
\end{tabular} & $\begin{array}{l}\text { IETIME } \\
\text { NEWEX } \\
\text { NEWLOC } \\
\text { NEWCON } \\
\text { NEWID }\end{array}$ & $\begin{array}{l}\text { When: IETIME as 0: building foreign } \\
\text { subsidiaries after IPO } \\
\text { Scope of international expansion: NEWLOC: } \\
\text { Number of new countries entered } \\
\text { NEWID: Institutional distance was included } \\
\text {; closeness of early international market: } \\
\text { different location/continent for international } \\
\text { expansion }\end{array}$ \\
\hline & \begin{tabular}{|l} 
New Venture \\
International \\
Exploration
\end{tabular} & \begin{tabular}{|l|} 
Early \\
Internationalizati \\
on \\
Broader scope of \\
subsequent \\
international \\
expansion
\end{tabular} & $\begin{array}{l}\text { IETIME } \\
\text { NEWEX } \\
\text { NEWLOC } \\
\text { NEWCON } \\
\text { NEWID }\end{array}$ & $\begin{array}{l}\text { When: IETIME as 1: building foreign } \\
\text { subsidiaries before IPO } \\
\text { Scope of international expansion: NEWLOC: } \\
\text { Number of new countries entered } \\
\text { NEWID: Institutional distance was included } \\
\text {; closeness of early international market: } \\
\text { different location/continent for international } \\
\text { expansion }\end{array}$ \\
\hline $\begin{array}{l}\text { New Venture } \\
\text { Growth }\end{array}$ & $\begin{array}{l}\text { New Venture } \\
\text { Growth }\end{array}$ & $\begin{array}{l}\text { New Ventures } \\
\text { Growth }\end{array}$ & $\begin{array}{l}\text { LOGREVTGROW } \\
\text { TH } \\
\text { LOGEMPGROWT } \\
\text { H } \\
\text { SURVIVAL }\end{array}$ & $\begin{array}{l}\text { New Venture Revenue Growth as } \\
\text { Performance } \\
\text { New Venture Size Growth } \\
\text { New Venture Failure (dissolution)-Reverse } \\
\text { for New Venture Survival }\end{array}$ \\
\hline $\begin{array}{l}\text { Technology } \\
\text { Capabilities }\end{array}$ & \begin{tabular}{|l|} 
Technology \\
Capabilities
\end{tabular} & $\begin{array}{l}\text { New Ventures' } \\
\text { subsequent } \\
\text { Technology } \\
\text { Development }\end{array}$ & $\begin{array}{l}\text { LOGRDGROWTH } \\
\text { PATENTGROWT } \\
\text { H }\end{array}$ & $\begin{array}{l}\text { Subsequent R\&D Commitment } \\
\text { New Product Development }\end{array}$ \\
\hline $\begin{array}{l}\text { Technological } \\
\text { Knowledge } \\
\text { Structure }\end{array}$ & $\begin{array}{l}\text { Technological } \\
\text { Integrated } \\
\text { Knowledge }\end{array}$ & $\begin{array}{l}\text { Technological } \\
\text { integrated } \\
\text { patents }\end{array}$ & TECHCAT & $\begin{array}{l}\text { Count for Patent Categories } \\
\text { Technological Integrated Patents: } \\
\text { Diversification of patent structure }\end{array}$ \\
\hline
\end{tabular}

\footnotetext{
${ }^{4}$ Different measures were created for operationalizing the concept of scope of international expansion: number of international entries (NEWEX), number of new countries entered (NEWLOC), number of continents where international new venture operates (NEWCON), and institutional distance (NEWID) of all countries entered. And these measures are highly correlated with each other, which support the evidence that measures are along with the same variable. Given the concept of exploration: experiment and seek new knowledge, therefore, I choose number of new countries entered as the final measure for scope of international expansion.
} 


\begin{tabular}{|l|l|l|l|l|}
\hline $\begin{array}{l}\text { Relational } \\
\text { Knowledge } \\
\text { Exchange }\end{array}$ & $\begin{array}{l}\text { Domestic } \\
\text { Knowledge Ties }\end{array}$ & $\begin{array}{l}\text { Number of ties } \\
\text { in domestic } \\
\text { network }\end{array}$ & DOMALL & Number of alliances in US. \\
\cline { 2 - 5 } & $\begin{array}{l}\text { Foreign } \\
\text { Knowledge Ties }\end{array}$ & $\begin{array}{l}\text { Number of ties } \\
\text { with foreign } \\
\text { partners }\end{array}$ & FORALL & Number of alliances with foreign partners. \\
\hline $\begin{array}{l}\text { Geographic } \\
\text { Knowledge } \\
\text { Dynamics }\end{array}$ & $\begin{array}{l}\text { Geographic } \\
\text { luster } \\
\text { Technology } \\
\text { Intensity }\end{array}$ & $\begin{array}{l}\text { Highly invest in } \\
\text { R\&D and the } \\
\text { frequency of } \\
\text { renewal of } \\
\text { technological } \\
\text { foundation }\end{array}$ & LOCTECG & Patent Growth at the regional level \\
\cline { 2 - 5 } & $\begin{array}{l}\text { Geographic } \\
\text { Cluster Foreign } \\
\text { Competition } \\
\text { Density }\end{array}$ & $\begin{array}{l}\text { The number of } \\
\text { proximate firms } \\
\text { internationalizati } \\
\text { on }\end{array}$ & LOCFORN & FDI at the regional level \\
\hline
\end{tabular}




\section{Chapter 5 Analytical Procedures and Results}

This chapter deals with the results of the quantitative analysis of my theoretical

framework. First, I present the list of different analyses to test the drivers of international ambidexterity and the relationship between international ambidexterity and new venture growth. Then, the test results for hypotheses developed in Chapter 3 are presented. In the third section, the research findings are summarized.

\subsection{Analytical procedures}

The model is broken into two sections, and each section answers one of the research questions, 1) "Do firms pursuing international ambidexterity achieve higher growth than those who do not?" and 2) "What drives firms to build international ambidexterity". The first question tested the meaningfulness of international ambidexterity for new venture growth (Hypothesis 6) and this relationship can be positively moderated by technology capabilities (Hypothesis 7). And the second question evaluates the relationship between hypothesized drivers and international ambidexterity, Hypotheses 1-5 in the analysis.

Different types of regression models were chosen based on the characteristics of the variables included in the model. Table 3 provides an overview of the different analytical techniques being used. For the first set of tests on potential drivers to international ambidexterity (Hypotheses 1-5), I tested two different outcomes (early internationalization and degree of subsequent international exploitation). Because early internationalization (IETIME) is a dummy variable, I used probit analysis to test the hypotheses. In the probit model, the inverse standard normal distribution of the probability is modeled as a linear combination of the predictors. One of the more useful aspects of probit regression is that it outputs the probability of the event which 
will fall between 0 and 1 . Therefore, given a set of independent variables, we could predict the probability of the event occurring using a Probit specification.

And subsequent international exploitation was measured in three different ways: new locations, new continents, and larger institutional distances, I used different analytical tools to test the related hypotheses. New location (NEWLOC) and new continents (NEWCON) are both count numbers, so the ordinary least squares (OLS) method for event count data results in biased, inefficient, and inconsistent estimates (Long 1997), thus I used a negative binomial approach. I also used a linear regression model to test institutional distances (NEWID).

Table 3 Summary of statistics procedure for each hypothesis

\begin{tabular}{|c|c|c|c|}
\hline Dependent Variables & Measures & Hypotheses & $\begin{array}{l}\text { Analytical } \\
\text { Technique }\end{array}$ \\
\hline $\begin{array}{l}\text { Early } \\
\text { Internationalization }\end{array}$ & IETIME & $\mathrm{H} 1 \mathrm{a}, \mathrm{H} 2 \mathrm{a}, \mathrm{H} 3 \mathrm{a}, \mathrm{H} 4 \mathrm{a}, \mathrm{H} 5 \mathrm{a}$ & Probit Regression \\
\hline \multirow{3}{*}{$\begin{array}{l}\text { Subsequent } \\
\text { International } \\
\text { exploitation }\end{array}$} & NEWLOG & $\mathrm{H} 1 \mathrm{~b}, \mathrm{H} 2 \mathrm{~b}, \mathrm{H} 3 \mathrm{~b}, \mathrm{H} 4 \mathrm{~b}, \mathrm{H} 5 \mathrm{~b}$ & Negative Binomial \\
\hline & NEWCON & $\mathrm{H} 1 \mathrm{~b}, \mathrm{H} 2 \mathrm{~b}, \mathrm{H} 3 \mathrm{~b}, \mathrm{H} 4 \mathrm{~b}, \mathrm{H} 5 \mathrm{~b}$ & Negative Binomial \\
\hline & NEWID & $\mathrm{H} 1 \mathrm{~b}, \mathrm{H} 2 \mathrm{~b}, \mathrm{H} 3 \mathrm{~b}, \mathrm{H} 4 \mathrm{~b}, \mathrm{H} 5 \mathrm{~b}$ & Linear Regression \\
\hline Revenue Growth & AVEREVGROWTH & H6, H7 & Linear Regression \\
\hline Size Growth & AVEEMGROWTH & H6, H7 & Linear Regression \\
\hline $\begin{array}{l}\text { Market Growth } \\
\text { (Deleted later since } \\
\text { there were too many } \\
\text { missing values) }\end{array}$ & AVEMKTGROWTH & H6, H7 & Linear Regression \\
\hline
\end{tabular}

For the second stage of testing my theoretical model (hypotheses 6 and 7), I used two different approaches to test how international ambidexterity impacts new ventures growth. I used average revenue growth as the outcome and tested how and under what conditions early internationalization and subsequent international exploitation impact the revenue growth of new ventures (AVEREVGROWTH). I also test whether international ambidexterity impacts the size 
growth (AVEEMPGROWTH) of new ventures. Descriptive statistics were assessed to ensure normal distribution of the data, and that outliers would not influence variable means. To account for the outlying values, I took the log value of the following variables: REVTGROWTH, EMPGROWTH, RDGROWTH and created new variables LOGREVTGROWTH, LOGEMPGROWTH, LOGRDGRWOTH. I used STATA 11 to create graphs for these log variables and, as you can see in the Figure 5, normality was shown in these graphs. Some outliers were identified within some variables, such as international new locations, but the subsequent removal of these new ventures didn't provide a significant change in the results. I use an OLS linear regression model to test the results, since growth measures are continuous and show a normal distribution, as shown in Figure 5.

Figure 5 LOG value of growth variables

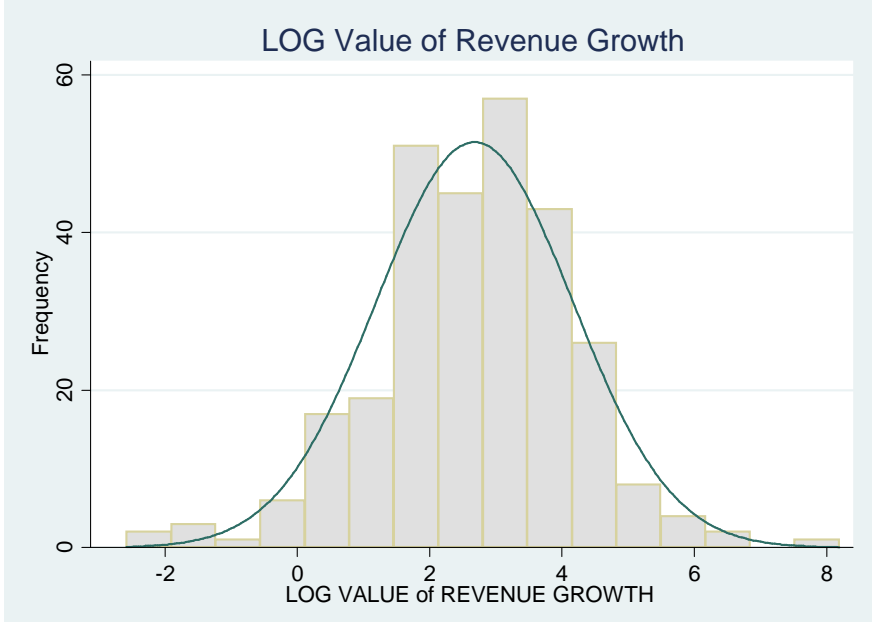




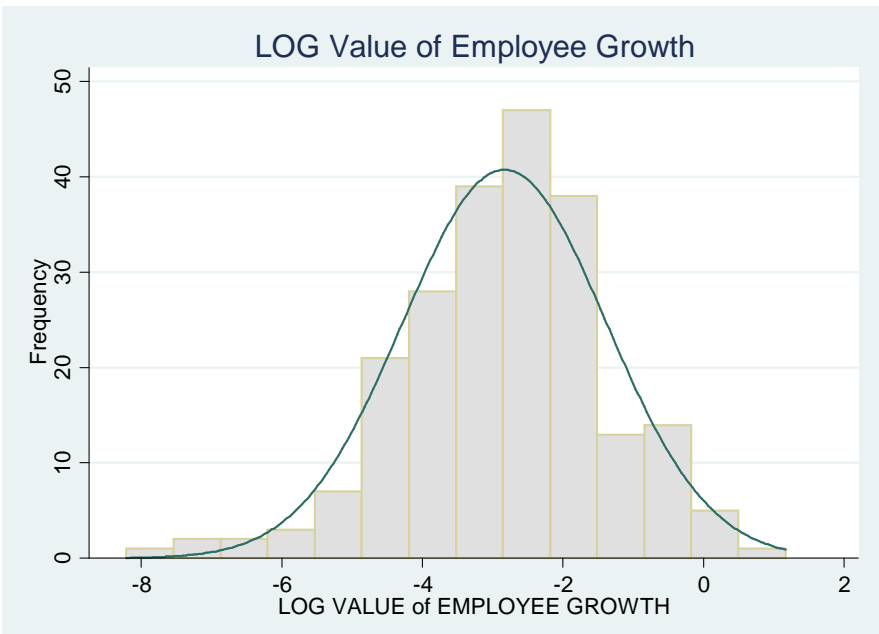

Because the research model contains two stages, structural equation modeling might have been helpful. However, this technique was ruled out because the key variable (early internationalization) is a dummy variable and is only measured with a single item.

I created interaction terms to test the interaction between external and internal effects. Each variable used to test interaction was mean-centered in order to reduce multicollinearity.

In this study, several hypotheses were tested based on attributes of the new venture's patents, alliances and early international activities. Some new ventures didn't have these activities, so while they remained in the sample they received a zero value.

\subsection{Results report}

This section presents the results of the study. First, descriptive statistics are presented. This is followed by summaries of the results of the analyses for each of the hypotheses.

\subsubsection{Descriptive summaries}

Table 4 and Table 5 provide descriptive statistics on all the variables related to the internationalization of new ventures and their growth. The average age of the new ventures during IPO time was 5.37 with the range from 1 to 8 . Nearly half of the new ventures in the sample went international before issuing an IPO, while the number of countries entered early 
ranged from 1 to 27 . This is a larger sample of international new ventures compared to previous study by Fernhaber and Li. (2010), which identified 40 firms reporting international sales out of 150 IPO new ventures. See note below. And, for firms that experienced later internationalization, new countries ranged from 0 to 33. Two hundred eighty five (285) of the 311 new ventures provided revenue growth, and $62 \%$ of them survived until at least the most recent year for which data were available.

For these 311 international new ventures, $69 \%$ of the firms issued IPOs before 2000 . And $43 \%$ of the 311 international new ventures are in computer related industries, while $26 \%$ are in the communication industry and $9 \%$ are in the semiconductor industry. A total of $24 \%$ of the sample is in the health and biotechnology industries. 
Table 4 Descriptive summary of international expansion of 311 international new ventures

\begin{tabular}{|l|c|c|c|c|c|}
\hline \multicolumn{1}{|c|}{ Variable } & Observation & Mean & SD & Min & Max \\
\hline $\begin{array}{l}\text { Early } \\
\text { Internationalization }\end{array}$ & 311 & 0.56 & 0.50 & 0 & 1 \\
\hline Total Early Entries & 311 & 2.10 & 4.14 & 0 & 35 \\
\hline $\begin{array}{l}\text { Total Early New } \\
\text { Countries }\end{array}$ & 311 & 1.83 & 3.30 & 0 & 27 \\
\hline $\begin{array}{l}\text { Total Early } \\
\text { Continents }\end{array}$ & 311 & 1.02 & 1.43 & 0 & 10 \\
\hline $\begin{array}{l}\text { Total Early } \\
\text { Institutional } \\
\text { Distance }\end{array}$ & 311 & 1.03 & 2.17 & 0 & 20.30 \\
\hline Total Late Entries & 311 & 4.93 & 7.76 & 0 & 63 \\
\hline $\begin{array}{l}\text { Total Late New } \\
\text { Countries }\end{array}$ & 311 & 3.73 & 5.17 & 0 & 33 \\
\hline $\begin{array}{l}\text { Total Late } \\
\text { Continents }\end{array}$ & 311 & 1.49 & 1.80 & 0 & 11 \\
\hline $\begin{array}{l}\text { Total late } \\
\text { Institutional } \\
\text { Distance }\end{array}$ & 311 & 2.50 & 3.76 & 0 & 23.53 \\
\hline
\end{tabular}


Table 5 Descriptive summary of 311 international new ventures

\begin{tabular}{|c|c|c|c|c|c|c|}
\hline & Variable & Observation & Mean & SD & Min & Max \\
\hline \multirow[t]{5}{*}{$\begin{array}{c}\text { Dependent } \\
\text { Variable }\end{array}$} & $\begin{array}{c}\text { AVEREVGROWTH } \\
(\mathrm{LOG})\end{array}$ & 285 & 2.68 & 1.49 & -2.58 & 8.19 \\
\hline & $\begin{array}{c}\text { AVEMKTGROWTH } \\
(\mathrm{LOG})\end{array}$ & 99 & 4.58 & 1.82 & -2.00 & 10.05 \\
\hline & $\begin{array}{c}\text { AVEREVGROWTH } \\
\text { (Ratio) }\end{array}$ & 300 & 3.40 & 8.55 & -1 & 120.7 \\
\hline & $\begin{array}{c}\text { AVEMKTGROWTH } \\
\text { (Ratio) }\end{array}$ & 282 & 0.23 & 1.04 & -0.99 & 12.41 \\
\hline & Survival & 311 & 0.62 & 0.49 & 0 & 1 \\
\hline \multirow[t]{11}{*}{$\begin{array}{l}\text { Control } \\
\text { Variable } \\
\end{array}$} & $\begin{array}{c}\text { Employee Growth } \\
\text { (LOG) }\end{array}$ & 290 & 0.10 & 0.28 & -0.38 & 3.21 \\
\hline & R\&D Growth (LOG) & 246 & 0.89 & 1.45 & -6.17 & 6.14 \\
\hline & Age When IPO & 311 & 5.37 & 1.73 & 1 & 9 \\
\hline & IPO Size (LOG) & 311 & 4.28 & 0.64 & 0.96 & 7.42 \\
\hline & $\begin{array}{l}\text { First Day Return } \\
\text { (LOG) }\end{array}$ & 258 & 3.59 & 1.53 & -2.30 & 6.26 \\
\hline & IPO Year Dummy & 311 & 0.69 & 0.46 & 0 & 1 \\
\hline & $\begin{array}{l}\text { Industry Dummy } \\
\text { Computerrelated }\end{array}$ & 311 & 0.43 & 0.50 & 0 & 1 \\
\hline & $\begin{array}{l}\text { Industry Dummy } \\
\text { Communication }\end{array}$ & 311 & 0.26 & 0.44 & 0 & 1 \\
\hline & $\begin{array}{l}\text { Industry Dummy } \\
\text { Semiconductor }\end{array}$ & 311 & 0.09 & 0.29 & 0 & 1 \\
\hline & $\begin{array}{l}\text { Industry Dummy } \\
\text { Medical health }\end{array}$ & 311 & 0.13 & 0.34 & 0 & 1 \\
\hline & $\begin{array}{l}\text { Industry Dummy } \\
\text { Biotechnology }\end{array}$ & 311 & 0.09 & 0.29 & 0 & 1 \\
\hline
\end{tabular}


Table 6 and 7 provides descriptive statistics on all the internationalization variables for both international exploration and international ambidextrous new ventures. The new ventures in this sample which went international before issuing their IPOs have entered 1-27 countries "early." Interestingly, firms which were later in their internationalization entered 0-26 new countries. For these 175 early internationalizing new ventures, $62 \%$ survived.

For these 175 international new ventures, $58 \%$ issued IPOs before 2000 . Further, $43 \%$ of these 175 international new ventures are in computer related industries while $26 \%$ are in the communication industry and $12 \%$ are in the semiconductor industry. A total of $19 \%$ of the firms in this group are in the health and biotechnology industries. 
Table 6 Descriptive summary of 175 early internationalizing new ventures

\begin{tabular}{|l|c|c|c|c|c|}
\hline \multicolumn{1}{|c|}{ Variable } & Observation & Mean & SD & Min & Max \\
\hline IETIME & 175 & 1 & 0 & 1 & 1 \\
\hline $\begin{array}{l}\text { Total Early } \\
\text { Entries }\end{array}$ & 175 & 3.73 & 4.94 & 1 & 35 \\
\hline $\begin{array}{l}\text { Total Early New } \\
\text { Countries }\end{array}$ & 175 & 3.26 & 3.84 & 1 & 27 \\
\hline $\begin{array}{l}\text { Total Early } \\
\text { Continents }\end{array}$ & 175 & 1.82 & 1.48 & 1 & 10 \\
\hline $\begin{array}{l}\text { Total Early } \\
\text { Institutional } \\
\text { Distance }\end{array}$ & 175 & 1.84 & 2.63 & 1 & 20.30 \\
\hline Total Late Entries & 175 & 3.98 & 7.38 & 0 & 63 \\
\hline $\begin{array}{l}\text { Total Late New } \\
\text { Countries }\end{array}$ & 175 & 3.06 & 4.92 & 0 & 26 \\
\hline $\begin{array}{l}\text { Total Late } \\
\text { Continents }\end{array}$ & 175 & 0.98 & 1.44 & 0 & 7 \\
\hline $\begin{array}{l}\text { Total Late } \\
\text { Institutional } \\
\text { Distance }\end{array}$ & 175 & 2.15 & 3.62 & 0 & 18.84 \\
\hline
\end{tabular}


Table 7 Descriptive summary of 175 early internationalizing new ventures

\begin{tabular}{|c|c|c|c|c|c|c|}
\hline & Variable & Observation & Mean & SD & Min & Max \\
\hline \multirow[t]{5}{*}{$\begin{array}{c}\text { Dependent } \\
\text { Variable }\end{array}$} & $\begin{array}{c}\text { AVEREVGROWTH } \\
(\mathrm{LOG})\end{array}$ & 160 & 2.78 & 1.40 & -2.12 & 8.19 \\
\hline & $\begin{array}{c}\text { AVEMKTGROWTH } \\
(\mathrm{LOG})\end{array}$ & 59 & 4.52 & 1.88 & -2.00 & 10.05 \\
\hline & $\begin{array}{c}\text { AVEREVGROWTH } \\
\text { (Ratio) }\end{array}$ & 169 & 2.63 & 10.10 & -0.11 & 120.70 \\
\hline & $\begin{array}{c}\text { AVEMKTGROWTH } \\
\text { Growth (Ratio) }\end{array}$ & 155 & 0.20 & 0.69 & -0.99 & 3.84 \\
\hline & Survival & 175 & 0.62 & 0.49 & 0 & 1 \\
\hline \multirow[t]{11}{*}{$\begin{array}{l}\text { Control } \\
\text { Variable }\end{array}$} & $\begin{array}{l}\text { Employee Growth } \\
\text { (LOG) }\end{array}$ & 119 & -2.71 & 1.39 & -7.20 & 1.17 \\
\hline & R\&D Growth (LOG) & 246 & 0.89 & 1.45 & -6.17 & 6.14 \\
\hline & Age When IPO & 175 & 5.52 & 1.72 & 1 & 8 \\
\hline & IPO Size (LOG) & 175 & 18.14 & 0.67 & 16.28 & 21.24 \\
\hline & $\begin{array}{l}\text { First Day Return } \\
\text { (LOG) }\end{array}$ & 175 & 3.56 & 1.41 & -1.61 & 6.23 \\
\hline & IPO Year Dummy & 175 & 0.58 & 0.49 & 0 & 1 \\
\hline & $\begin{array}{l}\text { Industry Dummy } \\
\text { Computerrelated }\end{array}$ & 175 & 0.43 & 0.50 & 0 & 1 \\
\hline & $\begin{array}{l}\text { Industry Dummy } \\
\text { Communication }\end{array}$ & 175 & 0.26 & 0.44 & 0 & 1 \\
\hline & $\begin{array}{l}\text { Industry Dummy } \\
\text { Semiconductor }\end{array}$ & 175 & 0.12 & 0.33 & 0 & 1 \\
\hline & $\begin{array}{l}\text { Industry Dummy } \\
\text { Medical health }\end{array}$ & 175 & 0.13 & 0.33 & 0 & 1 \\
\hline & $\begin{array}{l}\text { Industry Dummy } \\
\text { Biotechnology }\end{array}$ & 175 & 0.06 & 0.24 & 0 & 1 \\
\hline
\end{tabular}


A correlation analysis of the variables is given in Table 8. Among these correlationsdifferent measures for the same variable, subsequent international exploitation, showed high correlation, this provides evidence that these measures consistently tested the same variable (international exploitation or international exploration). Yet, there is conceptual independence among the different measures of international exploitation, thus I separated the analyses for sensitivity tests.

Interestingly, different measures for growth are not highly correlated, such as Revenue Growth and Market Growth. Therefore, I only included Revenue Growth in the study because market growth was explained by more external factors and also has market growth has too many missing values. 
Table 8 Correlation of variables for 311 international new ventures

\begin{tabular}{|c|c|c|c|c|c|c|c|c|c|c|c|c|c|c|c|c|c|c|c|c|c|c|c|c|}
\hline & $\begin{array}{c}\text { Revenue } \\
\text { Growth } \\
\text { (LOG) }\end{array}$ & \begin{tabular}{|l|} 
Average \\
Revenue \\
Growth \\
(Ratio)
\end{tabular} & Survive & \begin{tabular}{|c|} 
Average \\
Emply-y- \\
mentt \\
Growth \\
(Ratio)
\end{tabular} & \begin{tabular}{|c|}
$\begin{array}{c}\text { Employee } \\
\text { Growth } \\
\text { (LOG) }\end{array}$ \\
\end{tabular} & \begin{tabular}{|c} 
R\&D \\
Growth \\
(LOG)
\end{tabular} & $\begin{array}{l}\text { Age } \\
\text { When } \\
\text { IPO }\end{array}$ & $\begin{array}{c}\text { IPO Size } \\
\text { (LOG) }\end{array}$ & \begin{tabular}{|c|}
$\begin{array}{c}\text { First Day } \\
\text { Return } \\
\text { (LOG) }\end{array}$ \\
\end{tabular} & $\begin{array}{l}\text { IPO Year } \\
\text { Dummy }\end{array}$ & $\begin{array}{c}\text { Compu- } \\
\text { ter } \\
\text { related }\end{array}$ & \begin{tabular}{|c|}
$\begin{array}{c}\text { Comm- } \\
\text { unication }\end{array}$ \\
\end{tabular} & $\begin{array}{c}\text { Semicon- } \\
\text { ductor }\end{array}$ & Medical & \begin{tabular}{|l|} 
Biotech \\
\end{tabular} & IETIME & \begin{tabular}{|l|l|} 
Total \\
Early \\
Entries
\end{tabular} & \begin{tabular}{l|l} 
Total & T. \\
Early & E. \\
New & C \\
Countries s &
\end{tabular} & \begin{tabular}{|l|}
$\begin{array}{l}\text { Total } \\
\text { Early } \\
\text { Continent } \\
\text { s } \\
\end{array}$ \\
\end{tabular} & \begin{tabular}{|l} 
Total \\
Early \\
thnstituti- \\
onal \\
Distance
\end{tabular} & \begin{tabular}{|l|} 
Total \\
Late \\
Entries
\end{tabular} & $\left|\begin{array}{l}\text { Total } \\
\text { Late New } \\
\text { Countries }\end{array}\right|$ c & sontinents & $\begin{array}{l}\text { Total } \\
\text { S Late } \\
\text { Instituti- } \\
\text { onal } \\
\text { Distance }\end{array}$ \\
\hline $\begin{array}{c}\text { Revenue Growth } \\
\text { (LOG) }\end{array}$ & 1.00 & & & & & & & & & & & & & & & & & & & & & & & \\
\hline $\begin{array}{c}\text { Average Revenue } \\
\text { Growth (Ratio) }\end{array}$ & -0.07 & 1.00 & & & & & & & & & & & & & & & & & & & & & & \\
\hline Survive & 0.74 & 0.06 & 1.00 & & & & & & & & & & & & & & & & & & & & & \\
\hline $\begin{array}{c}\text { Average } \\
\text { Employment } \\
\text { Growth (Ratio) }\end{array}$ & 0.16 & 0.13 & 0.42 & 1.00 & & & & & & & & & & & & & & & & & & & & \\
\hline $\begin{array}{c}\text { Employee Growth } \\
\text { (LOG) }\end{array}$ & 0.13 & -0.11 & -0.01 & -0.10 & 1.00 & & & & & & & & & & & & & & & & & & & \\
\hline $\begin{array}{l}\text { R\&D Growth } \\
\text { (LOG) }\end{array}$ & 0.51 & 0.01 & 0.51 & 0.23 & 0.04 & 1.00 & & & & & & & & & & & & & & & & & & \\
\hline Age When IPO & 0.04 & -0.16 & 0.02 & -0.06 & -0.12 & 0.02 & 1.00 & & & & & & & & & & & & & & & & & \\
\hline IPO Size (LOG) & 0.42 & 0.07 & 0.29 & -0.05 & 0.00 & 0.24 & 0.07 & 1.00 & & & & & & & & & & & & & & & & \\
\hline $\begin{array}{c}\text { First Day Return } \\
\text { (LOG) }\end{array}$ & 0.21 & 0.05 & \begin{tabular}{|l|l|}
0.17 \\
\end{tabular} & 0.15 & 0.01 & 0.11 & -0.16 & 0.25 & 1.00 & & & & & & & & & & & & & & & \\
\hline IPO Year Dummy & -0.20 & 0.06 & -0.13 & 0.08 & -0.05 & -0.12 & -0.52 & -0.24 & 0.38 & 1.00 & & & & & & & & & & & & & & \\
\hline $\begin{array}{l}\text { Industry Dummy } \\
\text { Computerrelated }\end{array}$ & 0.10 & -0.09 & 0.16 & -0.03 & 0.02 & -0.03 & 0.10 & -0.09 & 0.19 & 0.05 & 1.00 & & & & & & & & & & & & & \\
\hline $\begin{array}{l}\text { Industry Dummy } \\
\text { Communication }\end{array}$ & 0.00 & 0.20 & -0.11 & 0.16 & -0.08 & -0.02 & -0.17 & 0.03 & 0.21 & 0.18 & -0.50 & 1.00 & & & & & & & & & & & & \\
\hline $\begin{array}{l}\text { Industry Dummy } \\
\text { Semiconductor }\end{array}$ & 0.08 & -0.05 & 0.08 & -0.04 & 0.11 & 0.06 & 0.18 & 0.16 & \begin{tabular}{|l}
$\mid$ \\
\end{tabular} & -0.14 & -0.29 & -0.19 & 1.00 & & & & & & & & & & & \\
\hline $\begin{array}{l}\text { Industry Dummy } \\
\text { Medical health }\end{array}$ & -0.04 & -0.04 & \begin{tabular}{|l|} 
\\
\end{tabular} & -0.08 & 0.04 & -0.10 & 0.00 & 0.06 & -0.30 & -0.20 & -0.36 & -0.23 & -0.14 & 1.00 & & & & & & & & & & \\
\hline
\end{tabular}




\begin{tabular}{|c|c|c|c|c|c|c|c|c|c|c|c|c|c|c|c|c|c|c|c|c|c|c|c|}
\hline $\begin{array}{c}\text { Industry Dummy } \\
\text { Biotechnology }\end{array}$ & -0.23 & -0.03 & -0.12 & -0.04 & -0.09 & 0.16 & -0.11 & -0.11 & -0.28 & 0.03 & -0.25 & -0.16 & -0.10 & -0.12 & 1.00 & & & & & & & & \\
\hline $\begin{array}{c}\text { Early } \\
\text { International } \\
\text { before IPO } \\
\end{array}$ & 0.11 & 0.11 & 0.09 & 0.04 & -0.03 & 0.07 & 0.19 & 0.13 & -0.01 & -0.29 & 0.02 & 0.03 & 0.08 & -0.03 & -0.15 & 1.00 & & & & & & & \\
\hline Total Early Entries & 0.34 & 0.06 & 0.28 & 0.04 & 0.08 & 0.24 & 0.10 & 0.42 & -0.03 & -0.27 & 0.02 & 0.05 & 0.00 & -0.01 & -0.13 & 0.49 & 1.00 & & & & & & \\
\hline $\begin{array}{l}\text { Total Early New } \\
\text { Countries }\end{array}$ & 0.34 & 0.06 & 0.27 & 0.03 & 0.08 & 0.24 & 0.10 & 0.40 & -0.02 & -0.27 & 0.02 & 0.07 & 0.00 & -0.01 & -0.13 & 0.53 & 0.99 & 1.00 & & & & & \\
\hline $\begin{array}{l}\text { Total Early } \\
\text { Continents }\end{array}$ & 0.31 & 0.14 & 0.22 & 0.00 & 0.06 & 0.20 & 0.16 & 0.38 & -0.01 & -0.32 & -0.01 & 0.09 & 0.06 & -0.03 & -0.16 & 0.67 & 0.90 & 0.93 & 1.00 & & & & \\
\hline $\begin{array}{c}\text { Total Early } \\
\text { Institutional } \\
\text { Distance } \\
\end{array}$ & 0.36 & 0.02 & 0.28 & 0.02 & 0.06 & 0.24 & 0.13 & 0.43 & -0.05 & -0.28 & 0.01 & 0.07 & 0.03 & -0.04 & -0.11 & 0.45 & 0.98 & 0.97 & 0.89 & 1.00 & & & \\
\hline Total Late Entries & 0.25 & -0.08 & 0.15 & -0.02 & 0.26 & 0.16 & 0.04 & 0.02 & 0.17 & 0.10 & 0.21 & -0.02 & -0.04 & -0.14 & -0.11 & -0.05 & -0.06 & -0.05 & -0.06 & -0.06 & 1.00 & & \\
\hline $\begin{array}{l}\text { Total Late New } \\
\text { Countries }\end{array}$ & 0.31 & -0.07 & 0.21 & -0.01 & 0.26 & 0.21 & 0.00 & 0.03 & 0.20 & 0.10 & 0.17 & 0.02 & -0.05 & -0.13 & -0.12 & -0.06 & -0.06 & -0.05 & -0.06 & -0.06 & 0.95 & 1.00 & \\
\hline $\begin{array}{l}\text { Total Late } \\
\text { Continents }\end{array}$ & 0.28 & -0.08 & 0.20 & 0.07 & 0.18 & 0.24 & -0.05 & -0.05 & 0.16 & 0.10 & 0.12 & 0.09 & -0.10 & -0.11 & -0.11 & -0.27 & -0.17 & -0.17 & -0.22 & -0.17 & 0.73 & 0.82 & 1.00 \\
\hline $\begin{array}{c}\text { Total Late } \\
\text { Institutional } \\
\text { Distance }\end{array}$ & 0.31 & -0.06 & 0.20 & -0.03 & 0.24 & 0.18 & 0.00 & 0.03 & 0.18 & 0.09 & 0.14 & 0.07 & -0.06 & -0.13 & -0.12 & -0.03 & -0.02 & 0.00 & -0.02 & -0.02 & 0.91 & 0.98 & 0.79 \\
\hline
\end{tabular}




\subsubsection{Regression results for drivers to international ambidexterity.}

This section presents the results of a series of four separate analyses, using different analytic techniques and different dependent variables. In each case, Model 1 is created using the control variables. Model 2 includes the control variables and the variables testing the main effects for technological integrated knowledge, relational knowledge exchange (direct and indirect alliances effect) and geographic cluster, thus offering an evaluation of hypotheses 1, 2, 4. The interaction effects for technological integrated knowledge and foreign alliances, as well as geographic cluster, were then added to the regression in models 3-8, respectively. Lastly, in model 9, all of the control, main effect and moderating variables were included.

In order to test for how integrated technological knowledge, domestic and foreign alliance, and geographic cluster drive international ambidexterity, H1a, H2a, H3a, H4a and H5a were tested using probit analyses. In Table 9, Model 2 obtained a non-statistically significant result, suggesting that integrated technological knowledge is not statistically related to early internationalization. Model 3 didn't achieve a statistically significant result either, which shows that not only is there no linear relationship between technological knowledge and early internationalization, but there is no curvilinear relationship either. Therefore H1a "Technological integrated knowledge possessed by new ventures has a curvilinear relationship with the likelihood that they go international at the early stage." is not supported through measuring dummy variable of early internationalization.

Similarly, Model 4 and Model 5, show that neither domestic alliances nor foreign alliances have a statistically significant effect on internationalization at the early stage. Therefore, $\mathrm{H} 2 \mathrm{a}$ "the more domestic alliances participated in by new ventures, the more likely new ventures are to go international at the early stage" is not supported. 
Model 6 shows a positive and statistically significant effect of the interaction of technological integrated knowledge with foreign alliances on early internationalization. Thus a positive $(\gamma=0.39)$ and significant $(\mathrm{p}<0.01)$ relationship with early internationalization is found, confirming, H3a "H3a: The relationship between the technological integrated knowledge and the likelihood of new ventures to go international at the early stage is moderated by their foreign alliance partnership."

A negative $(\gamma=-0.37)$ and significant $(\mathrm{p}<0.05)$ result is found in Model 7 , showing a negative and statistically significant effect of technology intensity in the geographic cluster on early internationalization of new ventures. Since the expected relationship is positive, this finding doesn't support hypothesis H4a : "H4a: the higher the technology intensity in the geographic cluster where new ventures are located, the more likely new ventures are to go international at the early stage."

However, the analysis found no statistically significant result for interaction of integrated technological knowledge and geographic cluster on early internationalization. Therefore, " $H 5 a$ : The relationship between the technological integrated knowledge and the likelihood of new ventures to go international at the early stage is moderated by foreign competition of the geographic cluster." is not supported. When all the variables are input into one model (Model 9), the log likelihood increased from-166.04 to $-53.54(\mathrm{p}<0.001)$, which provides a large/strong explanatory effect on dependent variable and the results are consistent with the individual tests. 
Table 9 Probit analyses for technological integrated knowledge, alliance ties and geographic cluster effects on early internationalization before IPO

\begin{tabular}{|c|c|c|c|c|c|c|c|c|c|}
\hline & $\begin{array}{l}\text { Model } \\
1\end{array}$ & $\begin{array}{l}\text { Model } \\
2 \\
\end{array}$ & $\begin{array}{l}\text { Model } \\
\mathbf{3}\end{array}$ & $\begin{array}{l}\text { Model } \\
4\end{array}$ & $\begin{array}{l}\text { Model } \\
5\end{array}$ & $\begin{array}{l}\text { Model } \\
6\end{array}$ & $\begin{array}{l}\text { Model } \\
7\end{array}$ & $\begin{array}{l}\text { Model } \\
8\end{array}$ & $\begin{array}{l}\text { Model } \\
9\end{array}$ \\
\hline _Constant & -0.20 & 0.08 & 0.08 & 0.04 & 0.07 & 0.17 & -1.39 & -0.88 & -5.62 \\
\hline \multicolumn{10}{|l|}{ Control Variables } \\
\hline Age When IPO & -0.04 & -0.04 & -0.04 & -0.04 & -0.04 & -0.04 & -0.07 & -0.03 & $-0.19 *$ \\
\hline IPO Size (LOG) & 0.06 & 0.05 & 0.05 & 0.06 & 0.04 & $\mathbf{0 . 0 0}$ & $\mathbf{0 . 0 2}$ & 0.09 & -0.16 \\
\hline First Day Return (LOG) & 0.02 & 0.02 & 0.02 & $\mathbf{0 . 0 2}$ & $\mathbf{0 . 0 3}$ & -0.04 & $\mathbf{0 . 0 1}$ & -0.02 & -0.04 \\
\hline IPO year (dummy variable) & $\overline{0.85 * * *}$ & $\overline{0.88 * * *}$ & $\overline{0.88} * * *$ & $\overline{0.84 * * *}$ & $\overline{0.87 * * *}$ & $1.03 * * *$ & $1.13 * * *$ & $1.01 * *$ & $2.01 * * *$ \\
\hline $\begin{array}{l}\text { Industry Dummy (Computer } \\
\text { Related) }\end{array}$ & $0.59 * *$ & $0.61 * *$ & $0.61 * *$ & $0.58 * *$ & $0.57 * *$ & $0.99 * *$ & $1.27 * *$ & $0.80 *$ & $1.84 * * *$ \\
\hline Industry Dummy (Communication) & $0.66 * *$ & $0.67 * *$ & $0.67 * *$ & $0.66 * *$ & $0.67 * *$ & $1.16 * *$ & $1.67 * * *$ & $0.78 *$ & $2.07 * *$ \\
\hline Industry Dummy (Semiconductor) & $0.86 * *$ & $0.89 * *$ & $0.82 * *$ & $0.86 * *$ & $0.90 * *$ & $1.30 * *$ & $1.62 * * *$ & $0.92 *$ & $1.58 *$ \\
\hline $\begin{array}{l}\text { Other Industry Dummy (Medical } \\
\text { Health and Biotechnology) }\end{array}$ & 0.24 & 0.24 & 0.24 & 0.24 & 0.26 & 0.56 & 0.35 & 0.25 & 0.28 \\
\hline \multicolumn{10}{|l|}{ Independent Variables } \\
\hline $\begin{array}{l}\text { Technological integrated } \\
\text { knowledge }\end{array}$ & & 0.01 & 0.01 & & & $\mathbf{0 . 0 0}$ & & 0.00 & 0.11 \\
\hline $\begin{array}{l}\text { Technological integrated } \\
\text { knowledge^ } 2^{\wedge}\end{array}$ & & & $\mathbf{0 . 0 0}$ & & & & & & -0.00 \\
\hline Domestic Alliances & & & & $\mathbf{0 . 0 0}$ & & & & & -0.07 \\
\hline Foreign Alliances & & & & & 0.05 & $0.34 *$ & & & $0.53 *$ \\
\hline $\begin{array}{l}\text { Technological Integrated } \\
\text { Knowledge } * \text { Foreign Alliances }\end{array}$ & & & & & & $0.39 * *$ & & & $0.40 *$ \\
\hline $\begin{array}{l}\text { Technology Intensity at Geographic } \\
\text { Cluster }\end{array}$ & & & & & & & $-0.37 *$ & & $-0.78 *$ \\
\hline $\begin{array}{l}\text { Foreign Competition at Geographic } \\
\text { Cluster }\end{array}$ & & & & & & & & -0.26 & -1.32 \\
\hline $\begin{array}{l}\text { Technological Integrated } \\
\text { Knowledge * Foreign Competition } \\
\text { at Geographic Cluster }\end{array}$ & & & & & & & & -33.20 & $-95.03 *$ \\
\hline Log Likelihood & $-166.04^{* * *}$ & $-165.84 * * *$ & $-165.83^{* * * *}$ & $-166.03 * * *$ & $-165.78 * * * *$ & $-159.95^{* * *}$ & $-90.93 * * *$ & $-94.13^{* * * *}$ & $-53.54 * * *$ \\
\hline Chi2 & 23.54 & 23.95 & 23.95 & 23.56 & 24.07 & 30.17 & 31.63 & 21.80 & 41.01 \\
\hline Observations & 257 & 257 & 257 & 257 & 257 & 257 & 154 & 152 & 107 \\
\hline
\end{tabular}

Two-tailed test: ${ }^{\dagger} p<.10,{ }^{*} p<.05,{ }^{* *} p<.01,{ }^{* * *} p<.001$ 
The relationship between the various drivers and early international exploration were also tested using negative binomial analysis. And in Table 10, Model 2 once again shows that integrated technological knowledge is not statistically related to early internationalization. This finding is consistent with the argument that "Technological integrated knowledge possessed by new ventures has a curvilinear relationship with the likelihood that they go international at the early stage." And H1a is not supported through measuring dummy variable of early internationalization.

In Model 4 and Model 5, a positive $(\gamma=0.07)$ and significant $(p<0.01)$ relationship between domestic alliances and early international exploration is confirmed, as is a positive $(\gamma=0.27)$ and significant $(\mathrm{p}<0.01)$ relationship between foreign alliances and early international exploration. Domestic alliances and foreign alliances both have positive and statistically significant effects on early international exploration. This supports the argument that "the more domestic alliances and more foreign alliances participated in by new ventures, the more likely new ventures are to pursue international exploration at the early stage".

Further, Model 6 shows a positive $(\gamma=0.20)$ and significant $(\mathrm{p}<0.01)$ relationship for the interaction effect on early international exploration, this confirms that the interaction of technological integrated knowledge with foreign alliances has an important impact on early international exploration. Therefore, " The relationship between the technological integrated knowledge and the likelihood of new ventures to pursue international exploration at the early stage is moderated by their foreign alliance partnership" is supported.

On the other hand, Model 7 didn't show a statistically significant effect of technology intensity in the geographic cluster on early international exploration, which doesn't support hypothesis $\mathrm{H} 4 \mathrm{a}$. In addition, the statement "The relationship between the technological 
integrated knowledge and the likelihood of new ventures to go international at the early stage is moderated by foreign competition of the geographic cluster." is not supported.

Finally, when all the variables are input into one model (Model 9), although the log likelihood increased from-417.19 to $-125.41(\mathrm{p}<0.001)$, which provides a large explanatory effect on the dependent variable, none of the variables show a statistically significant effect. 
Table 10 Negative binomial analyses for technological integrated knowledge, alliance ties and geographic cluster effects on scope of pre-IPO international expansion

\begin{tabular}{|c|c|c|c|c|c|c|c|c|c|}
\hline & Model 1 & Model 2 & Model 3 & Model 4 & Model 5 & Model 6 & Model 7 & Model 8 & Model 9 \\
\hline Constant & $-2.31 * *$ & $-2.29 * *$ & $-2.29 * *$ & $-2.42 * *$ & $-1.80 * *$ & $-1.90 * *$ & -0.04 & 2.34 & -0.14 \\
\hline \multicolumn{10}{|l|}{ Control Variables } \\
\hline Age When IPO & -0.06 & -0.07 & -0.07 & -0.06 & -0.09 & -0.08 & -0.08 & -0.07 & -0.04 \\
\hline IPO Size (LOG) & $0.59 * * *$ & $\mathbf{0 . 5 8} * * *$ & $\mathbf{0 . 5 8 * * *}$ & $\mathbf{0 . 5 6} * * *$ & $0.50 * *$ & $\mathbf{0 . 4 3} * *$ & $0.49 * *$ & $0.58 * *$ & -0.15 \\
\hline First Day Return (LOG) & -0.09 & -0.09 & -0.09 & -0.11 & -0.08 & -0.09 & -0.12 & -0.08 & -0.02 \\
\hline IPO year (dummy variable) & $-0.66 * *$ & $-0.67 * *$ & $-0.67 * *$ & $-0.63 * *$ & $-0.74 * * *$ & $-0.71 * * *$ & $-1.08 * * *$ & $-0.92 * *$ & $-0.65 * *$ \\
\hline $\begin{array}{l}\text { Industry Dummy (Computer } \\
\text { Related) }\end{array}$ & $1.40 * *$ & $1.40 * *$ & $1.41 * *$ & $1.46 * *$ & $1.28 * *$ & $1.55 * *$ & $3.15 * * *$ & $1.64 * *$ & $0.84 *$ \\
\hline $\begin{array}{l}\text { Industry Dummy } \\
\text { (Communication) }\end{array}$ & $1.48 * *$ & $1.48^{* * *}$ & $1.48 * *$ & $1.50 * *$ & $1.32 * *$ & $1.71 * *$ & $3.70 * * *$ & $1.57 * *$ & 0.95 \\
\hline Industry Dummy (Semiconductor) & $1.39 *$ & $1.38 *$ & $1.38 *$ & $1.55^{* * *}$ & $1.55 * * *$ & $1.80 * * *$ & $2.85 * *$ & $1.31 *$ & 1.02 \\
\hline $\begin{array}{l}\text { Other Industry Dummy (Medical } \\
\text { Health and Biotechnology) }\end{array}$ & $0.84 *$ & $0.84 *$ & $0.84 *$ & $0.97 *$ & 0.98* & $1.23^{*}$ & $1.77 *$ & 0.58 & 0.54 \\
\hline \multicolumn{10}{|l|}{ Independent Variables } \\
\hline $\begin{array}{l}\text { Technological integrated } \\
\text { knowledge }\end{array}$ & & $\mathbf{0 . 0 0}$ & $\mathbf{0 . 0 0}$ & & & $\mathbf{0 . 0 0}$ & & $\mathbf{0 . 0 0}$ & 0.02 \\
\hline $\begin{array}{l}\text { Technological integrated } \\
\text { knowledge }^{\wedge} 2\end{array}$ & & & -0.00 & & & & & & -0.00 \\
\hline Domestic Alliances & & & & $0.07 * *$ & & & & & -0.06 \\
\hline Foreign Alliances & & & & & $0.27 * *$ & $0.30 * *$ & & & 0.24 \\
\hline $\begin{array}{l}\text { Technological Integrated } \\
\text { Knowledge * Foreign Alliances }\end{array}$ & & & & & & $0.20 *$ & & & 0.09 \\
\hline $\begin{array}{l}\text { Technology Intensity at } \\
\text { Geographic Cluster }\end{array}$ & & & & & & & -0.15 & & -2.02 \\
\hline $\begin{array}{l}\text { Foreign Competition at } \\
\text { Geographic Cluster }\end{array}$ & & & & & & & & 1.36 & 0.19 \\
\hline $\begin{array}{l}\text { Technological Integrated } \\
\text { Knowledge* Foreign Competition } \\
\text { at Geographic Cluster }\end{array}$ & & & & & & & & $-50.27 *$ & -27.27 \\
\hline Log Likelihood & $-417.19 * * *$ & $-427.18^{* * * *}$ & $-417.188^{* * * *}$ & $-414.65 * * *$ & $-427.96 * * *$ & $-411.24 * * *$ & $-230.34 * * *$ & $-250.33^{* * * *}$ & $-125.41^{* * * *}$ \\
\hline Chi2 & 42.22 & 42.25 & 42.25 & 47.31 & 54.58 & 54.12 & 47.73 & 37.29 & 13.14 \\
\hline Observations & 257 & 257 & 257 & 257 & 257 & 257 & 154 & 154 & 154 \\
\hline
\end{tabular}


In order to test for how integrated technological knowledge, domestic and foreign alliances and geographic clusters drive subsequent international exploitation, H1b, H2b, H3b, H4b and H5b were tested using negative binomial analysis. Examining Model 2 in Table 11 shows a positive $(\gamma=0.05)$ and significant $(\mathrm{p}<0.01)$ effect with international exploration. This finding is consistent with the argument of $\mathrm{H} 1 \mathrm{~b}$ "The more technological integrated knowledge possessed by new ventures, the narrower the scope of their subsequent international expansion". Further, Model 4 shows a positive $(\gamma=0.04)$ and significant $(p<0.001)$ effect for domestic alliances while Model 5 shows a positive $(\gamma=0.10)$ and significant $(\mathrm{p}<0.001)$ effect for foreign alliances. Collectively, these results confirm that both have a positive, statistically significant effect on the propensity of new ventures to enter more new countries. Therefore, supporting the argument that " $H 2 b$ : the more domestic alliances participated in by new ventures, the broader the scope new ventures are to develop for the subsequent international expansion".

Also, the supposition that "The relationship between the technological integrated knowledge and the scope of the subsequent international expansion is moderated by their foreign alliance partnership" is also supported, because Model 6 shows a negative $(\gamma=-0.23)$ and significant $(\mathrm{p}<0.01)$ effect on international exploitation, which demonstrates a statistically significant effect of technological integrated knowledge with foreign alliances on late international exploitation.

On the other hand, Model 7 doesn't show a statistically significant effect of technology intensity in the geographic cluster on early international exploration, which doesn't support hypothesis $\mathrm{H} 4 \mathrm{~b}$ "the higher the technology intensity in the geographic cluster where new ventures are located, the more likely the new ventures are to develop narrower scope of the subsequent international expansion". In addition, Model 8 shows a non significant effect of the 
interaction term on international exploitation, thus the statement "The relationship between the technological integrated knowledge and the scope of the subsequent international expansion is moderated by foreign competition of the geographic cluster" is not supported. When all the variables are input into one model (Model 9), the results are consistent with individual input. 
Table 11 Negative binomial regression analyses for technological integrated knowledge, alliance ties and geographic cluster effects and scope of post-IPO international expansion

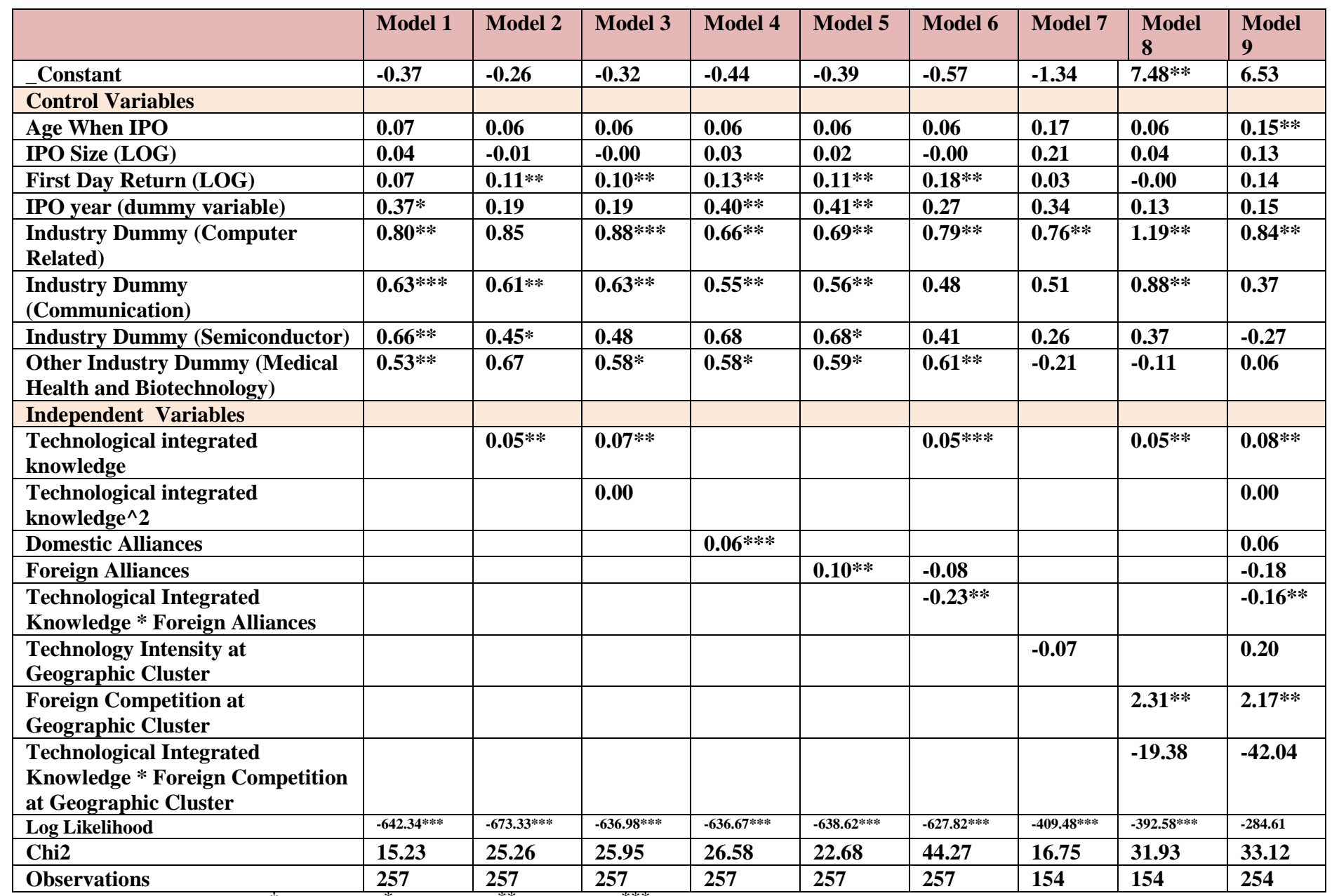

Two-tailed test: ${ }^{\dagger} p<.10,{ }^{*} p<.05,{ }^{* *} p<.01,{ }^{* * * *} p<.001$ 


\subsubsection{Regression results for International Ambidexterity's effect on new venture growth}

The results of the regression on the dependent variable, new venture growth, can be found in Table 12. Within Table 12, Model 1 presents the results of the control variables when regressed on new venture revenue growth. Model 2 and Model 3 within Table12 offer tests of the main effects from Hypothesis 6: whether early internationalization and early international exploration have effects on new venture revenue growth. Hypothesis 6 argues that international ambidextrous new ventures are more likely to grow than those with only international exploitation or international exploration strategies. In considering whether subsequent international exploitation affects new venture growth, Model 4 within Table 12 tests the effect of international exploitation. And, the interaction of early internationalization with subsequent international exploitation is evaluated with Model 5 and Model 6.

In considering the moderator effect of technological capabilities, Hypothesis 7 next posited a positive relationship between early internationalization and new venture growth, as well as a positive relationship between subsequent international exploitation and new venture growth. These moderating effects were tested in Models 8, 9, and 10 in the table. Lastly, in Model 10, all of the control, main effect and moderating variables were included.

Model 2 shows a non-statistically significant effect on revenue growth, which demonstrates that early internationalization is not statistically associated with new venture revenue growth. However, a higher degree of early international exploration is positively related with new venture growth, with a positive $(\gamma=0.08)$ and significant $(p<0.001)$ effect, as shown in Model 3. Model 4 shows a negative $(\gamma=-0.08)$ and significant $(p<0.001)$ effect of subsequent international exploitation on revenue growth. This indicates that having a broader scope of late internationalization is negatively associated with new venture growth. Furthermore, Model 6 
reveals a positive $(\gamma=0.01)$ and significant $(\mathrm{p}<0.001)$ effect on revenue growth, which demonstrates that the interaction of early international exploration with late international exploitation is statistically significantly associated with new venture revenue growth., This supports the argument of H6: New ventures pursuing international ambidexterity are more likely to grow than those pursuing only international exploration.”

Model 7 and Model 8 show identical positive $(\gamma=0.21)$ and significant $(p<0.01)$ effects of technological capabilities on revenue growth. However, Model 9 and Model 10 suggest that H7 "H7a: the relationship between international exploration and new venture growth is negatively moderated by the subsequent technology capabilities. H7b: the relationship between an international ambidexterity and new venture growth is positively moderated by the subsequent technology capabilities." is not supported.

When all the variables are input into one model (Model 11), the adjusted $\mathrm{R}^{\wedge} 2$ increases from 0.14 to $0.21(\mathrm{p}<0.001)$, which improves the explanatory effect for the dependent variable. 
Table 12 Regression analysis for international ambidexterity and international new venture growth

\begin{tabular}{|c|c|c|c|c|c|c|c|c|c|c|c|}
\hline & Model 1 & Model 2 & Model 3 & Model 4 & Model 5 & Model 6 & Model 7 & Model 8 & Model 9 & Model 10 & Model 11 \\
\hline \begin{tabular}{|c|} 
Constant \\
\end{tabular} & 0.34 & 0.33 & 0.81 & 0.30 & 0.25 & 1.10 & 3.04 & 3.07 & 2.81 & 2.81 & 2.82 \\
\hline \multicolumn{12}{|l|}{ Control Variables } \\
\hline Age When IPO & -0.04 & -0.04 & -0.04 & -0.05 & -0.05 & -0.07 & -0.10 & -0.10 & -0.11 & -0.11 & -0.11 \\
\hline IPO Size (LOG) & $0.35 * * *$ & $0.35 * * *$ & 0.21 & $0.37 * *$ & $0.37 * *$ & 0.17 & -0.00 & -0.04 & 0.05 & 0.05 & 0.02 \\
\hline First Day Return (LOG) & 0.11 & 0.11 & $0.12 * *$ & 0.08 & 0.08 & $0.12 * *$ & $0.18 * *$ & $0.17 * *$ & $0.13 * *$ & $0.13 * *$ & $0.13 * *$ \\
\hline IPO year (dummy variable) & $-0.70 * * *$ & $-0.69 * * *$ & $-0.64 * *$ & $-0.77 * * *$ & $-0.71 * * *$ & $-0.77 * * *$ & $-0.91 * * *$ & $-0.88 * * *$ & $-0.95 * * *$ & $-0.95 * * *$ & $-0.92 * * *$ \\
\hline $\begin{array}{l}\text { Industry Dummy (Computer } \\
\text { Related) }\end{array}$ & $1.28 * * *$ & $1.27 * * *$ & $1.17 * * *$ & $1.09 * * *$ & $1.01 * * *$ & $0.92 * * *$ & 0.16 & 0.17 & 0.07 & 0.07 & 0.06 \\
\hline $\begin{array}{l}\text { Industry Dummy } \\
\text { (Communication) }\end{array}$ & $1.07 * * *$ & $1.06 * * *$ & $0.95 * * *$ & $0.94 * *$ & $0.90 * *$ & $0.82 * *$ & -0.11 & -0.12 & -0.06 & -0.06 & -0.07 \\
\hline Industry Dummy (Semiconductor) & $1.41 * * *$ & $1.40 * * *$ & $1.32 * * *$ & $1.29 * * *$ & $1.23 * * *$ & $1.24 * * *$ & 0.51 & 0.53 & 0.47 & 0.47 & 0.46 \\
\hline $\begin{array}{l}\text { Other Industry Dummy (Medical } \\
\text { Health and Biotechnology) }\end{array}$ & $1.48 * * *$ & $1.48 * * *$ & $1.43 * * *$ & $1.37 * * *$ & $1.36 * * *$ & $1.30 * * *$ & $-1.32 * * *$ & $-1.27 * * *$ & $-1.11 * *$ & $-1.11 * *$ & $-1.07 * *$ \\
\hline \multicolumn{12}{|l|}{ Independent Variables } \\
\hline $\begin{array}{l}\text { Early Internationalization } \\
\text { before IPO }\end{array}$ & & 0.03 & & & 0.28 & & & & & & \\
\hline $\begin{array}{l}\text { Scope of Pre-IPO International } \\
\text { Expansion }\end{array}$ & & & $0.08 * * *$ & & & $0.11 * * *$ & & 0.03 & & & 0.06 \\
\hline \begin{tabular}{|l} 
Scope of Post-IPO \\
International Expansion \\
\end{tabular} & & & & $-0.08 * * *$ & $-0.10 * * *$ & $-0.07 * * *$ & & & $-0.07 * * *$ & $-0.07 * * *$ & $-0.07 * * *$ \\
\hline $\begin{array}{l}\text { Scope of Pre-IPO International } \\
\text { Expansion X Scope of Post- } \\
\text { IPO International Expansion }\end{array}$ & & & & & & $0.01 * *$ & & & & & $-\mathbf{0 . 0 0}$ \\
\hline $\begin{array}{l}\text { Technological Capabilities } \\
\text { (LOG) }\end{array}$ & & & & & & & $0.21 * *$ & $0.21 * *$ & $0.13 *$ & $0.13 *$ & $0.14 *$ \\
\hline $\begin{array}{l}\text { Technological Capabilities X } \\
\text { Scope of Pre-IPO International } \\
\text { Expansion }\end{array}$ & & & & & & & & 0.00 & & & 0.01 \\
\hline $\begin{array}{l}\text { Technological Capabilities X } \\
\text { Scope of Post-IPO } \\
\text { International Expansion } \\
\end{array}$ & & & & & & & & & 0.01 & 0.01 & -0.00 \\
\hline $\operatorname{Ad~R\wedge 2}$ & 0.14 & 0.24 & 0.17 & 0.23 & 0.24 & 0.27 & 0.15 & 0.14 & 0.21 & 0.21 & 0.21 \\
\hline \begin{tabular}{|l|} 
Observation \\
\end{tabular} & 235 & 235 & 235 & 235 & 235 & 235 & 185 & 185 & 185 & 185 & 185 \\
\hline F-Value & $5.89 * * *$ & $5.22 * * *$ & $6.24 * * *$ & 8.11*** & $7.64 * * *$ & $8.94 * * *$ & $4.47 * * *$ & 3.73*** & $5.56 * * *$ & $5.56 * * *$ & $4.45 * * *$ \\
\hline
\end{tabular}

Two-tailed test: ${ }^{\dagger} p<.10,{ }^{*} p<.05,{ }^{* *} p<.01,{ }^{* * * *} p<.001$ 
A summary of the results is provided in Table 13. This table indicates whether or not the

respective hypotheses were significantly supported by the data. This reveals that among the 13

hypotheses and sub-hypotheses, six were not supported, two were partially supported and five

were supported. Most notably, H6: New ventures pursuing international ambidexterity are more

likely to grow than those pursuing international exploration, was supported.

Table 13 Summary of the quantitative results

\begin{tabular}{|c|c|c|}
\hline Hypotheses & Support & Note \\
\hline $\begin{array}{l}\text { Hla: Technological integrated knowledge } \\
\text { possessed by new ventures has a curvilinear } \\
\text { relationship with the likelihood that they go } \\
\text { international at the early stage. }\end{array}$ & Not Supported & $\begin{array}{l}\text { No significant effect on early } \\
\text { internationalization; No significant effect on } \\
\text { early international exploration }\end{array}$ \\
\hline $\begin{array}{l}\text { H1b: The more technological integrated } \\
\text { knowledge possessed by new ventures, the } \\
\text { narrower the scope of their subsequent } \\
\text { international expansion. }\end{array}$ & Supported & $\begin{array}{l}\text { Positive Relationship for international } \\
\text { exploitation }\end{array}$ \\
\hline $\begin{array}{l}\text { H2a: the more domestic alliances } \\
\text { participated in by new ventures, the more } \\
\text { likely new ventures are to go international at } \\
\text { the early stage. }\end{array}$ & Partially Supported & $\begin{array}{l}\text { Positive Relationship between domestic } \\
\text { alliances and early international exploration }\end{array}$ \\
\hline $\begin{array}{l}\text { H2b: the more domestic alliances } \\
\text { participated in by new ventures, the broader } \\
\text { the scope new ventures are to develop for the } \\
\text { subsequent international expansion. }\end{array}$ & Supported & $\begin{array}{l}\text { Positive Relationship between domestic } \\
\text { alliances and later exploration }\end{array}$ \\
\hline $\begin{array}{l}\text { H3a: The relationship between the } \\
\text { technological integrated knowledge and the } \\
\text { likelihood of new ventures to go international } \\
\text { at the early stage is moderated by their } \\
\text { foreign alliance partnership. }\end{array}$ & Supported & $\begin{array}{l}\text { Interaction of foreign alliances and } \\
\text { technological integrated knowledge is } \\
\text { positively related to early internationalization } \\
\text { and early international exploration. }\end{array}$ \\
\hline $\begin{array}{l}\text { H3b: The relationship between the } \\
\text { technological integrated knowledge and the } \\
\text { scope of the subsequent international } \\
\text { expansion is moderated by their foreign } \\
\text { alliance partnership. }\end{array}$ & Supported & $\begin{array}{l}\text { Interaction of foreign alliances and } \\
\text { technological integrated knowledge is } \\
\text { positively related international exploitation }\end{array}$ \\
\hline $\begin{array}{l}\text { H4a: the higher the technology intensity in } \\
\text { the geographic cluster where new ventures } \\
\text { are located, the more likely new ventures are } \\
\text { to go international at the early stage. }\end{array}$ & Not Supported & $\begin{array}{l}\text { Negative Relationship between technological } \\
\text { intensity of geographic cluster and early } \\
\text { internationalization. }\end{array}$ \\
\hline $\begin{array}{l}\text { H4b: the higher the technology intensity in } \\
\text { the geographic cluster where new ventures } \\
\text { are located, the more likely the new ventures } \\
\text { are to a develop narrower scope of the } \\
\text { subsequent international expansion. }\end{array}$ & Not Supported & $\begin{array}{l}\text { No significant effect on international } \\
\text { exploitation }\end{array}$ \\
\hline $\begin{array}{l}\text { H5a: The relationship between the } \\
\text { technological integrated patents and the } \\
\text { likelihood of new ventures to go international } \\
\text { at the early stage is moderated by foreign } \\
\text { competition of the geographic cluster. }\end{array}$ & Partially Supported & $\begin{array}{l}\text { Interaction of foreign competition and } \\
\text { technological integrated knowledge is } \\
\text { negatively related to early internationalization. }\end{array}$ \\
\hline
\end{tabular}




\begin{tabular}{|l|l|l|}
\hline $\begin{array}{l}\text { H5b: The relationship between the } \\
\text { technological integrated patents and the } \\
\text { scope of the subsequent international } \\
\text { expansion is moderated by foreign } \\
\text { competition of the geographic cluster. }\end{array}$ & Not Supported & $\begin{array}{l}\text { No significant effect on international } \\
\text { exploitation }\end{array}$ \\
\hline $\begin{array}{l}\text { H6: New ventures pursuing international } \\
\text { ambidexterity are more likely to grow than } \\
\text { those pursuing international exploration. }\end{array}$ & Supported \\
\hline $\begin{array}{l}\text { H7a: the relationship between international } \\
\text { exploration and new ventures growth is } \\
\text { negatively moderated by the subsequent } \\
\text { technology capabilities. }\end{array}$ & Not Supported & $\begin{array}{l}\text { Early international exploration with later } \\
\text { international exploitation is related with new } \\
\text { venture growth. }\end{array}$ \\
\hline $\begin{array}{l}\text { H7b: the relationship between an } \\
\text { international ambidexterity and new ventures } \\
\text { growth is positively moderated by the } \\
\text { subsequent technology capabilities. }\end{array}$ & $\begin{array}{l}\text { Direct effect on new vent } \\
\text { indirect effect }\end{array}$ \\
\hline
\end{tabular}




\section{Chapter 6 Discussion and Conclusion}

Using a sample of IPO issuing international new ventures, this dissertation sought to build and test a theoretical model of international ambidexterity in order to investigate the internationalization process of new ventures. In order to demonstrating the conclusion of the analyses, first, I summarize the findings from quantitative analyses. This study complements and challenge current knowledge on the internationalization process of new ventures. The second section addressing research implications follows. Research implications of the results for ambidexterity literature, international new ventures and international management studies are followed by a discussion of the limitation of the study. This chapter concludes with final reflections on the managerial implications of international ambidexterity for new venture growth.

\subsection{Summary of quantitative findings}

The objective of the quantitative study was to examine how the internal knowledge (integrated technological knowledge) and external knowledge source (domestic and foreign alliances and geographic cluster) can directly and indirectly affect the level of international ambidexterity of new ventures. In addition, I also tested whether an international ambidexterity impacts new venture growth. Focusing on the resource advantages, information availability and managerial mindset, I used a knowledge based view to guide my prediction of the direct influence of technological integrated knowledge, domestic alliances and technology intensity at the geographic level on the likelihood of new ventures going international at an early stage. By adding arguments from international experiences, I also predict the indirect effect of foreign alliances and foreign competition at the geographic location on international exploitation, international exploration and international ambidexterity. Consistent with expectations, my results suggest that the interaction of foreign alliances and technological integrated knowledge 
produces a positive impact on early internationalization. However, neither the technological integrated knowledge nor domestic alliances has a significant direct effect on early internationalization. The technology intensity of geographic location has a negative effect on firm early internationalization. I also did further analyses to test the interaction of technological integrated knowledge and technology intensity of cluster on early internationalization. And, once again, counter to my expectations, there were no significant indirect effects, either. This result suggests that new ventures from technologically intense locations may be more likely to pursue late internationalization. This is consistent to my theoretical argument that firms in technological clusters innovate more than geographically isolated firms (Feldman, 1994; Baptist $\&$ Swann, 1998). Thus, they are more likely to build a unique resource for further exploitation. It is interesting to observe that the degree of international exploration at the early stage is associated with both domestic and foreign alliances. My results show the direct effect of alliances on new ventures' early international exploration. The more domestic alliances a new venture has, the more likely it is to explore international markets at an early stage. This direct effect is also shown when I tested foreign alliances. In addition, the interaction of technological integrated knowledge and foreign alliances also produces a positive effect on early international exploration. This supports the assumption about insufficient resources of new ventures, therefore, the more ties they build the more likely they are to get the resources they need for international expansion. However, technology intensity at the geographic level doesn't show a direct effect on international exploration of new ventures, but a negative indirect effect was shown from foreign competition at the geographic level, which suggests that the higher foreign competition at the geographic level, new ventures with higher technological integrated knowledge are less likely to pursue early international exploration. This result may suggest that 
for new ventures with stronger technology and an international knowledge base, the success of other firms in the domestic country will reduce the entrepreneurial incentives of new venture for further foreign exploration behaviors. Another explanation would be that, as the industry grows domestically, the firm can find enough customers domestically and does not "need" foreign customers.

Another interesting conclusion deriving from the analyses is related to the later international exploitation. Technological integrated knowledge shows positive effect on later international exploitation. In addition, I did an additional test for a curvilinear effect of technological integrated knowledge, which shows no curvilinear relationship between technological integrated knowledge and later international exploitation. Thus the results suggest that the more technological integrated knowledge the firm possesses, the more likely the new venture is to pursue a high level of international exploitation. This is supportive statement of the traditional learning argument for MNCs, which suggested that knowledge advantages support an incremental learning approach for internationalization (Ghoshal \& Bartlett, 1990; Gupta \& Govindarajan, 2000; Kogut \& Zander, 1993; Kostova \& Roth, 2003; Nohria \& Ghoshal, 1997; Tsai, 2002). Both domestic and foreign alliances built at early stages have positive direct impacts on later international exploitation of new ventures. However, a negative effect was shown from interaction of technological integrated knowledge and foreign alliances, suggesting that the more foreign alliances a new venture has, the less international exploitation a new venture with more technological integrated knowledge would pursue. This is an interesting finding that new ventures with more technological integrated knowledge and less foreign alliances are more likely to pursue international exploration at the later stage. This is supportive of the argument that international expansion can be considered as seeking international opportunities for technology 
implementation. However, there is neither a direct nor an indirect effect of geographic location on the degree of international exploitation at later stages. One explanation may be that firms seek and integrate new knowledge and resources through the internationalization process, thus they build new channels to learn externally rather than rely on home regions.

The results also confirm that new venture revenue growth is affected by early international exploration and later international exploitation. My study shows that both early international exploration and later international exploitation have positive direct effects on the revenue growth of new ventures. And interaction of early international exploration and later international exploitation has a positive effect on revenue growth. This suggests that new ventures that have a higher level of early international exploration are more likely to experience growth if they also have a higher level of later international exploitation. This supports the international ambidexterity argument for international new ventures. Although the technological capability development does not moderate the relationship between international ambidexterity and revenue growth in this study, it shows positive direct effect on revenue growth. One of the explanations is that new ventures commit innovation efforts to increase domestic revenue and enhance domestic competitive advantages. More analyses can be done by looking at whether international sales can be affected by the interaction of international ambidexterity and technological development.

Overall, I draw two important conclusions from my findings. First, I developed the construct of international ambidexterity by using time sequential scales. And the results show that the interaction of early international exploration and later international exploitation provides a positive effect on new venture revenue growth, which is consistent with the international ambidexterity argument. These findings answer my first two research questions: To what extent 
can new ventures achieve an international ambidexterity?" and "Do those new ventures which develop an international ambidextrous capability accelerate their growth faster than those without this capability?"

Second, my research question "What factors can help new ventures develop an international ambidextrous capability?" was answered by finding the direct effect of alliances on international expansion of new ventures. This is consistent to the arguments that new ventures seek resources from relational exchanges based on alliances. However, the direct effect of internal resources was not shown from my results. One of the explanations may be that patents may not capture all the tacit knowledge a firm has, and therefore they can only partially explain technological integrated knowledge. Further studies should include more information about the new products the firms have developed to investigate the impact of the resource advantages on international ambidexterity. In the next section, I will specify how these findings contribute to the current literature.

\subsection{Research implications}

In my study, I seek to contribute to the current literature regarding, 1) international new ventures 2) organizational and strategic ambidexterity and 3) how multiple factors interact with each other to understand new venture international learning, in following ways:

First of all, international growth is often seen as a firm's attempt to either leverage the existing knowledge in their domestic country or learn from host countries by exploring novel technologies and knowledge. Thus, knowledge acquisition in both domestic and international markets can be used to explain the processes of internationalization (Presutti et al. 2007). This idea assumes that, the broader the international market scope of a new venture, the more learning sources a new venture would have in the further growth process (McDougall and Oviatt, 2005; 
Zahra et al, 2000). The learning benefit of early international expansion depends upon the firm's capabilities to exploit and explore knowledge learned from both domestic and foreign knowledge sources (Sapienza et al., 2006). Consistent with this expectation, my dissertation found that firms which pursued early international exploration by entering more new countries before issuing an IPO had higher levels of revenue growth. This is also consistent with the international entrepreneurship literature that new ventures have been viewed as entities primarily focused on finding and identifying opportunities (Shane and Venkataraman, 2000). As entrepreneurs, managers of new ventures may carry out new combinations of strategies, thus exploring new opportunities in the international markets.

However, although the framework of new cases concerning international new ventures challenges traditional arguments concerning incremental processes, path dependency and knowledge dissemination to demonstrate the internationalization process of large MNCs, the international expansions model of MNCs is still valid when new ventures achieve a mature stage of their life cycle. Thus, international exploitation follows early international exploration. Therefore, both traditional models (Johanson and Vahlne, 2006) and international entrepreneur frameworks (Oviatt and McDougall, 1994) serve as key tools for explaining the internationalization process of new ventures.

Moreover, the existing literature provides less explanation on how early internationalization impacts post-internationalization performance (Zahra, 2005). Although a small number of studies investigated the outcomes, these works provided inconsistent results regarding the effects of internationalization on these new ventures. My study found that being early to internationalization does not impact the speed of growth of new venture. However, the 
degree of early international exploration has a positive impact on revenue growth. And this effect was positively enhanced by later international exploitation.

Secondly, although the literature on new ventures' ambidexterity capabilities is not well explored, these young firms provide a context to better understand the ambidexterity development process, including antecedents and contingent factors. From the antecedent perspective, previous literature has argued that slack resources are one of the key factors for developing ambidextrous capabilities. New ventures lack specific resources, a sufficient customer base and the necessary investments in their structures. They are assumed to be more susceptible to failure because of their "liability of newness". However, my results suggest that technological knowledge has no impact on international exploration before an IPO, but it has a positive impact on international expansion after an IPO. And my findings that alliances have positive effects on international exploration and international exploitation are consistent with the supposition that new ventures reply heavily on alliances for international expansion.

International new ventures provide a nice context for understanding how firms can develop competencies that exploit their core knowledge and explore new market opportunities for further growth. The results from this study also reveal that continuous investment in technological capabilities will impact new venture growth. And commitment to innovation doesn't interact with international expansion, which supported my argument that new ventures can explore in different knowledge domains than they exploit. Therefore, based on these findings, there are two questions researchers may wish to pursue. First, does a new venture need to focus on overcoming "liability of newness" in technological environment before pursuing international exploration? Second, does being in the IPO stage limit the degree to which a firm can pursue dual ambidexterity in both international business and the technological domain? 
Thirdly, because of the liability and limited resources that characterize new ventures, these international new ventures are dependent on external resources and relationships for capability development. Internally, new ventures face constraints to their international learning in terms of limited capital, management, time, experience and information resources. Externally, the dynamic environment including technological, social and economic changes and the rapid obsolescence of products or limited domestic demand pressures new ventures to undertake an international exploration. Therefore, to resolve the tension between exploitation and exploration, firms must develop new capabilities, which may be dependent upon specific external factors.

Both domestic alliances and foreign alliances exhibit significant relationships with new venture international exploration. New ventures may have insufficient financial resources and prior alliances, thus technological resources are the key for other alliance partners to choose cooperation. Therefore, new ventures who have domestic alliance partners are the ones who have the basic capability to exploit existing knowledge. It is also likely that their partnerships have helped them with allocating resources in domestic market. Therefore, the new ventures with partners for knowledge exchange are more likely to have strong capabilities to seek and pursue the opportunities in international markets.

\subsection{Limitation of the current study}

Certainly, the results of the dissertation have provided research insights on the relationships between knowledge sources and international expansion of new ventures. In spite of the progress to our understanding about international new ventures, several limitations of the study must be acknowledged.

First, few firms are able to achieve the status of being publicly traded; even fewer are able to do so as an international new venture. By sampling this particular population, therefore, I 
potentially exclude a large group of privately held international new ventures. Thus the findings presented here, which are based on publically available secondary data, may not be representative of all international new ventures. Clearly, further empirical research can address this issue by including both private and public firms, and perhaps, by using primary as well as secondary data.

A second limitation of this study is the focus on a limited set of high technology industries. As industries are different from each other in their innovation activities and alliances relationships, more industries may need to be identified and included in the sampling process. Although I controlled for industry factors, these high technology industries are the stimulants of economic growth and have been among the most important industries undertaking IPOs. Some of the firms are more focused on market growth rather than sales increases. Some traditional industries, such as manufacturing firms in traditional industries, may have stronger objectives for sales growth from international expansion. Therefore, further research may benefit from examining a broader set of industries.

A third limitation of the study is that I used patents to operationalize the resource advantages of new ventures. And the direct effect of internal resources was not shown from my results. As I mentioned earlier, one of the explanations may be that patents may not capture all the tacit knowledge a firm has, and therefore, they may only partially explain technological integrated knowledge. Further studies should include more information about the new products the firms have developed and focused on single industry. Or, by using primary data, future studies my attempt to assess the presence of other knowledge-based assets. Such changes may help to operationalize resource advantages in a more refined way in order to understand impact on international ambidexterity. 


\section{Conclusion}

From a management viewpoint, my dissertation built and tested a unified framework that indicates the need for the development of an international ambidexterity as a strategic investment for new venture growth. An international ambidexterity facilitates internationalization at the early stages of venture formation and accomplishes entrepreneurial growth in an international context while simultaneously respecting entrepreneurial dynamics. It is not an easy task for an organization to solve the dilemma associated with international exploitation and exploration. The managers' task is not only to identify the optimal balance for internationalization, but to also benefit from analyzing their knowledge structure and their firm's position in social networks and geographic locations, so as to be able to take advantages of internationalization.

In brief, international growth is often seen as a firm's attempt to either leverage the existing knowledge in their domestic country or learn from host countries by exploring novel technologies and knowledge. First, my study on the international ambidexterity of new ventures contributes to the existing international management literature by bridging the traditional perspective on the incremental learning of MNCs and new insights on exploratory learning among international entrepreneurs. The learning benefit of early international expansion depends upon the firm's capabilities to exploit and explore knowledge learned from both domestic and foreign knowledge sources (Sapienza et al., 2006). Second, I tested the drivers to international ambidexterity and its growth outcome. Though the literature on new ventures' ambidexterity capabilities is not well explored, these young firms provide a context to better understand the ambidexterity development process including antecedents, outcomes and contingent factors. Third, results from my analyses show that domestic alliances and foreign alliances exhibit significant relationships with new venture international exploration. Therefore, 
inter-organizational learning can link to social capital and network perspectives in international entrepreneurship research; mimetic learning can help investigating social aspects of international entrepreneurship studies. And, finally, new ventures should be encouraged to build interorganizational networks, domestically and internationally, if they truly wish to pursue growth. 


\section{Reference}

Agarwal, R., Echambadi, R., Franco, A. M., \& Sarkar, M. B. (2004). Knowledge transfer through inheritance: Spinout generation, development, and survival. Academy of Management Journal, 47(4), 501-522.

Al-Laham, A., \& Souitaris, V. (2008). Network embeddedness and new-venture internationalization: Analyzing international linkages in the German biotech industry. [Article]. Journal of Business Venturing, 23(5), 567-586.

Anand, J., Mesquita, L. F., \& Vassolo, R. S. (2009). The Dynamics of Multimarket Competition in Exploration and Exploitation Activities. [Proceedings Paper]. Academy of Management Journal, 52(4), 802-821.

Andriopoulos, C., \& Lewis, M. W. (2009). Exploitation-Exploration Tensions and Organizational Ambidexterity: Managing Paradoxes of Innovation. [Article]. Organization Science, 20(4), 696-717.

Argote, L. (1999). Organizational Learning. Norwell, Massachusetts: Kluwer Academic Publishers.

Audretsch, D. B., \& Feldman, M. P. (1996). R\&D spillovers and the geography of innovation and production. American Economic Review, 86(3), 630-640.

Auh, S., \& Menguc, B. (2005). Balancing exploration and exploitation: The moderating role of competitive intensity. [Article]. Journal of Business Research, 58(12), 1652-1661.

Autio, E. (2005). Creative tension: the significance of Ben Oviatt's and Patricia McDougall's article 'toward a theory of international new ventures'. [Article]. Journal of International Business Studies, 36(1), 9-19. 
Autio, E., Sapienza, H. J., \& Almeida, J. G. (2000). Effects of age at entry, knowledge intensity, and imitability on international growth. [Article]. Academy of Management Journal, 43(5), 909-924.

Bania, N., Calkins, L. N., \& Dalenberg, D. R. (1992). The effects of regional science and technology policy on the geographic-distribution of industrial research-and-development laboratories. Journal of Regional Science, 32(2), 209-228.

Baptista, R., \& Swann, P. (1998). Do firms in clusters innovate more? Research Policy, 27(5), $525-540$.

Barney, J. (1991). Firm Resources and Sustained Competitive Advantage. Journal of Management, 17(1), 22.

Bartlett, C. A., \& Ghoshal, S. (1998). Managing across borders: the transnational solution (2 ed.): Harvard Business School Press.

Baum, J. A. C., Calabrese, T., \& Silverman, B. S. (2000). Don't go it alone: Alliance network composition and startups' performance in Canadian biotechnology. [Article]. Strategic Management Journal, 21(3), 267-294.

Baum, J. A. C., \& Mezias, S. J. (1993). Competition, institutional linkages, and organizational growth. [Article]. Social Science Research, 22(2), 131-164.

Baum, J. R., Locke, E. A., \& Smith, K. G. (2001). A multidimensional model of venture growth. [Article]. Academy of Management Journal, 44(2), 292-303.

Beckman, C. M. (2006). The influence of founding team company affiliations on firm behavior. [Article]. Academy of Management Journal, 49(4), 741-758.

Bell, G. G. (2005). Clusters, networks, and firm innovativeness. Strategic Management Journal, 26(3), 287-295. 
Bengtsson, M., Eriksson, J., \& Kock, S. (2005). The Importance of Competition and Cooperation for the Exploration of Innovation Opportunities. In P. Ghauri, A. Hadjikhani \& J. Johanson (Eds.), Managing Opportunity Development in Business Networks.

Benner, M. J. (2002). Process management and technological innovation: A longitudinal study of the photography and paint industries. [Article]. Administrative Science Quarterly, 47(4), 676-706.

Benner, M. J., \& Tushman, M. L. (2003). Exploitation, exploration, and process management: The productivity dilemma revisited. [Review]. Academy of Management Review, 28(2), 238-256.

Bierly, P. E., Damanpour, F., \& Santoro, M. D. (2009). The Application of External Knowledge: Organizational Conditions for Exploration and Exploitation. [Article]. Journal of Management Studies, 46(3), 481-509.

Birkinshaw, J., Brannen, M. Y., \& Tung, R. L. From a distance and generalizable to up close and grounded: Reclaiming a place for qualitative methods in international business research INTRODUCTION. [Editorial Material]. Journal of International Business Studies, 42(5), 573-581.

Brouthers, L. E., Nakos, G., Hadjimarcou, J., \& Brouthers, K. D. (2009). Key Factors for Successful Export Performance for Small Firms. [Article]. Journal of International Marketing, 17(3), 21-38.

Brush, C. G., \& Vanderwerf, P. A. (1992). A comparison of methods and sources for obtaining estimates of new venture performance. [Article]. Journal of Business Venturing, 7(2), $157-170$. 
Camison, C., \& Villar-Lopez, A. Effect of SMEs' International Experience on Foreign Intensity and Economic Performance: The Mediating Role of Internationally Exploitable Assets and Competitive Strategy. [Review]. Journal of Small Business Management, 48(2), 116151.

Cantwell, J., \& Mudambi, R. (2005). MNE Competence-Creating Subsidiary Mandates. Strategic Management Journal, 26, 20.

Cao, Q., Gedajlovic, E., \& Zhang, H. P. (2009). Unpacking Organizational Ambidexterity: Dimensions, Contingencies, and Synergistic Effects. [Article]. Organization Science, 20(4), 781-796.

Carlson, K. D., \& Hatfield, D. E. (2004). Strategic Management Research and the Cumulative Knowledge Perspective. . In D. Bergh \& D. Ketchen (Eds.), Research Methodology in Strategy and Management (Vol. 1): Elsevier Publishing.

Carr, J. C., Haggard, K. S., Hmieleski, K. M., \& Zahra, S. A.(2010) A study of the moderating effects of firm age at internationalization on firm survival and short-term growth. [Article]. Strategic Entrepreneurship Journal, 4(2), 183-192.

Carrincazeaux, C., Lung, Y. N., \& Rallet, A. (2001). Proximity and localisation of corporate R\&D activities. Research Policy, 30(5), 777-789.

Carroll, G. R., \& Hannan, M. T. (1989). Density dependence in the evolution of populations of newspaper organizations. [Article]. American Sociological Review, 54(4), 524-541.

Chen, R. R., \& Martin, M. J. (2001). Foreign expansion of small firms: The impact of domestic alternatives and prior foreign business involvement. [Article]. Journal of Business Venturing, 16(6), 557-574. 
Chung, H. J., Chen, C. C., \& Hsieh, T. J. (2007). First geographic expansion of startup firms: Initial size and entry timing effects. [Article]. Journal of Business Research, 60(4), 388395.

Coeurderoy, R., \& Murray, G. (2008). Regulatory environments and the location decision: evidence from the early foreign market entries of new-technology-based firms. [Article]. Journal of International Business Studies, 39(4), 670-687.

Cohen, W. M., \& Levinthal, D. A. (1990). Absorptive-capacity-a new perspective on learning and innovation. [Article]. Administrative Science Quarterly, 35(1), 128-152.

Coviello, N. E. (2006). The network dynamics of international new ventures. [Article]. Journal of International Business Studies, 37(5), 713-731.

Damanpour, F. (1996). Organizational complexity and innovation: Developing and testing multiple contingency models. [Article]. Management Science, 42(5), 693-716.

Danneels, E. (2002). The dynamics of product innovation and firm competences. [Article]. Strategic Management Journal, 23(12), 1095-1121.

Delios, A., \& Beamish, P. W. (2001). Survival and Profitability: The role of experience and intangible assets in Foreign Subsidiary Performance. Academy of Management Journal, 44(5), 12.

DiMaggio, P. J., \& Powell, W. W. (1983). "The ""iron cage"" revisited: Institutional isomorphism and collective rationality in organizational fields". American Sociological Review 48(2), 14.

Dunning, J. H. (1998). Location and the multinational enterprise: A neglected factor? [Article]. Journal of International Business Studies, 29(1), 45-66. 
Eisenhardt, K. M. (1989). Building theories from case-study research. [Article]. Academy of Management Review, 14(4), 532-550.

Eisenhardt, K. M., \& Martin, J. A. (2000). Dynamic capabilities: What are they? Strategic Management Journal, 2l(10-11), 1105-1121.

Ellison, G., \& Glaeser, E. L. (1997). Geographic concentration in US manufacturing industries: A dartboard approach. Journal of Political Economy, 105(5), 889-927.

Fabian, F., Molina, H., \& Labianca, G. (2009). Understanding Decisions to Internationalize by Small and Medium-sized Firms Located in an Emerging Market. [Review]. Management International Review, 49(5), 537-563.

Fang, C., Lee, J., \& Schilling, M. A. Balancing Exploration and Exploitation Through Structural Design: The Isolation of Subgroups and Organizational Learning. [Article]. Organization Science, 21(3), 625-642.

Fang, C., \& Levinthal, D. (2009). Near-Term Liability of Exploitation: Exploration and Exploitation in Multistage Problems. [Article]. Organization Science, 20(3), 538-551.

Feldman, M. P. (1994). Knowledge complementarity and Innovation. Small Business Economics, 6(5), 363-372.

Fernandez, Z., \& Nieto, M. J. (2006). Impact of ownership on the international involvement of SMEs. [Article]. Journal of International Business Studies, 37(3), 340-351.

Fernhaber, S. A., Gilbert, B. A., \& McDougall, P. P. (2008). International entrepreneurship and geographic location: an empirical examination of new venture internationalization. [Article; Proceedings Paper]. Journal of International Business Studies, 39(2), 267-290. 
Fernhaber, S. A., \& Li, D. The Impact of Interorganizational Imitation on New Venture International Entry and Performance. [Article]. Entrepreneurship Theory and Practice, 34(1), 1-30.

Fernhaber, S. A., McDougall, P. P., \& Oviatt, B. M. (2004, Aug 06-11). Exploring the role of industry structure in new venture internationalization. Paper presented at the 64th Annual Meeting of the Academy-of-Management, New Orleans, LA.

Fernhaber, S. A., McDougall, P. P., \& Oviatt, B. M. (2007). Exploring the role of industry structure in new venture internationalization. [Proceedings Paper]. Entrepreneurship Theory and Practice, 31(4), 517-542.

Filatotchev, I., Liu, X. H., Buck, T., \& Wright, M. (2009). The export orientation and export performance of high-technology SMEs in emerging markets: The effects of knowledge transfer by returnee entrepreneurs. [Proceedings Paper]. Journal of International Business Studies, 40(6), 1005-1021.

Filatotchev, I., \& Piesse, J. (2009). R\&D, internationalization and growth of newly listed firms: European evidence. [Article]. Journal of International Business Studies, 40(8), 12601276.

Floyd, C. (1999). Strategic thinking and the new science; Planning in the midst of chaos, complexity and change. [Book Review]. Long Range Planning, 32(6), 623-624.

Francis, J., Zheng, C. C., \& Mukherji, A. (2009). An Institutional Perspective on Foreign Direct Investment. [Article]. Management International Review, 49(5), 565-583.

Freeman, S., \& Cavusgil, S. T. (2007). Toward a typology of commitment states among managers of born-global firms: A study of accelerated internationalization. [Article]. Journal of International Marketing, 15(4), 1-40. 
Frost, T. S. (2001). The Geographic Sources of Foreign Subsidiaries' Innovations. Strategic Management Journal, 22, 23.

Gabrielsson, M., Kirpalani, V. H. M., Dimitratos, P., Solberg, C. A., \& Zucchella, A. (2008). Born globals: Propositions to help advance the theory. [Article]. International Business Review, 17(4), 385-401.

Gassmann, O., \& Keupp, M. M. (2007). The competitive advantage of early and rapidly internationalising SMEs in the biotechnology industry: A knowledge-based view. [Article]. Journal of World Business, 42(3), 350-366.

George, G. (2005). Slack resources and the performance of privately held firms. [Article]. Academy of Management Journal, 48(4), 661-676.

Ghoshal, S., \& Bartlett, C. A. (1990). The Multinational Corporation as an Interorganizational Network. Academy of Management Review, 15(4).

Gibson, C. B., \& Birkinshaw, J. (2004). The antecedents, consequences, and mediating role of organizational ambidexterity. [Proceedings Paper]. Academy of Management Journal, 47(2), 209-226.

Gilbert, B. A., McDougall, P. P., \& Audretsch, D. B. (2006). New venture growth: A review and extension. [Review]. Journal of Management, 32(6), 926-950.

Gnyawali, D. R., \& Madhavan, R. (2001). Cooperative Networks and Competitive Dynamics: A structural Embeddedness Perspective. Academy of Management Review, 26(3), 25.

Gupta, A. K., \& Govindarajan, V. (2000). Knowledge Flows Within Multinational Corporations. Strategic Management Journal, 21, 24.

Gupta, A. K., Smith, K. G., \& Shalley, C. E. (2006). The interplay between exploration and exploitation. [Article]. Academy of Management Journal, 49(4), 693-706. 
Haahti, A., Madupu, V., Yavas, U., \& Babakus, E. (2005). Cooperative strategy, knowledge intensity and export performance of small and medium sized enterprises. [Review]. Journal of World Business, 40(2), 124-138.

Hamel, G., Doz, Y. L., \& Prahalad, C. K. (1989). Collaborative adventures-reply. [Letter]. Harvard Business Review, 67(2), 176-176.

Hansen, M. T. (1999). The Search-Transfer Problem: The Role of Weak Ties in Sharing Knowledge across Organization Subunits. Administrative Science Quarterly, 44(1).

He, Z. L., \& Wong, P. K. (2004). Exploration vs. exploitation: An empirical test of the ambidexterity hypothesis. [Article]. Organization Science, 15(4), 481-494.

Hedlund, G. (1986). The hypermodern MNC: A heterarchy? . Human Resource Management, 25(1), 27.

Henisz, W. J., \& Delios, A. (2001). Uncertainty, imitation, and plant location: Japanese multinational corporations, 1990-1996. [Review]. Administrative Science Quarterly, $46(3), 443-475$.

Hoang, H., \& Rothaermel, F. T. Leveraging internal and external experience: exploration , exploitation, and R\&D project performance. [Article]. Strategic Management Journal, 31(7), 734-758.

Holmqvist, M. (2004). Experiential learning processes of exploitation and exploration within and between organizations: An empirical study of product development. [Article]. Organization Science, 15(1), 70-81.

Hunter, J. E., \& Schmidt, F. L. (2004). Methods of Meta-Analysis: Correcting Error and Bias in Research Findings (2 ed.). Thousand Oaks, California: Sage Publications Ltd. 
Im, G. Y., \& Rai, A. (2008). Knowledge sharing ambidexterity in long-term interorganizational relationships. [Article]. Management Science, 54(7), 1281-1296.

Inkpen, A. C., \& Tsang, E. W. K. (2005). Social Capital, Networks and Knowledge Transfer. Academy of Management Review, 30(1), 20.

Jaffe, A. B., Trajtenberg, M., \& Henderson, R. (1993). Geographic location of knowledge spillovers as evidenced by patent citations. Quarterly Journal of Economics, 108(3), 577598.

Jain, B. A., \& Kini, O. (1994). The post-issue operating performance of IPO firms. [Article]. Journal of Finance, 49(5), 1699-1726.

Jansen, J. J. P., Tempelaar, M. P., van den Bosch, F. A. J., \& Volberda, H. W. (2009). Structural Differentiation and Ambidexterity: The Mediating Role of Integration Mechanisms. [Review]. Organization Science, 20(4), 797-811.

Johanson, J., \& Vahlne, E. J. (1990). The Mechanism of Internationalisation. International Marketing Review, 7(4), 14.

Jones, M. V., \& Coviello, N. E. (2005). Internationalisation: conceptualising an entrepreneurial process of behaviour in time. [Article]. Journal of International Business Studies, 36(3), 284-303.

Kane, G. C., \& Alavi, M. (2007). Information technology and organizational learning: An investigation of exploration and exploitation processes. [Article]. Organization Science, 18(5), 796-812.

Katila, R., \& Ahuja, G. (2002). Something old, something new: A longitudinal study of search behavior and new product introduction. [Article]. Academy of Management Journal, 45(6), 1183-1194. 
Keupp, M. M., \& Gassmann, O. (2009). The Past and the Future of International Entrepreneurship: A Review and Suggestions for Developing the Field. [Review]. Journal of Management, 35(3), 600-633.

Knight, G. A., \& Cavusgil, S. T. (2004). Innovation, organizational capabilities, and the bornglobal firm. [Article]. Journal of International Business Studies, 35(2), 124-141.

Kogut, B., \& Zander, U. (1993). Knowledge of The firm and The Evolutionary Theory of The Multinational Corporation. Journal of International Business Studies, 24(4), 21.

Kostova, T. (1999). Transnational Transfer of Strategic Organizational Practices: A Contextual Perspective. Academy of Management Review, 24(2), 17.

Kostova, T., \& Roth, K. (2003). Social Capital in Multinational Corporations And a MicroMacro Model of its Formation. Academy of Management Review, 28(2), 21.

Kotabe, M., Parente, R., \& Murray, J. Y. (2007). Antecedents and outcomes of modular production in the Brazilian automobile industry: a grounded theory approach. Journal of International Business Studies, 38(1), 84-106.

Koza, M. P., \& Lewin, A. Y. (1998). The co-evolution of strategic alliances. [Review]. Organization Science, 9(3), 255-264.

Kuemmerle, W. (2002). Home base and knowledge management in international ventures. [Article]. Journal of Business Venturing, 17(2), 99-122.

Lavie, D., \& Rosenkopf, L. (2006). Balancing exploration and exploitation in alliance formation. [Article]. Academy of Management Journal, 49(4), 797-818.

Lavie, D., Stettner, U., \& Tushman, M. L. (2010). Exploration and Exploitation Within and Across Organizations. [Article]. Academy of Management Annals, 4, 109-155. 
Lee, J., \& Lee, H. (2003). Exploration and exploitation in the presence of network externalities. [Article]. Management Science, 49(4), 553-570.

Leiblein, M. J., \& Reuer, J. J. (2004). Building a foreign sales base: the roles of capabilities and alliances for entrepreneurial firms. [Article]. Journal of Business Venturing, 19(2), 285307.

Levinthal, D. A., \& March, J. G. (1993). The Myopia of Learning. [Article]. Strategic Management Journal, 14, 95-112.

Levitt, B., \& March, J. G. (1988). Organizational Learning. Annual Review of Sociology, 14, 22.

Liesch, P. W., \& Knight, G. A. (1999). Information internalization and hurdle rates in small and medium enterprise internationalization. [Article]. Journal of International Business Studies, 30(2), 383-394.

Lin, Z., Yang, H. B., \& Demirkan, I. (2007). The performance consequences of ambidexterity in strategic alliance formations: Empirical investigation and computational theorizing. [Article]. Management Science, 53(10), 1645-1658.

Loane, S., Bell, J., \& McNaughton, R. (2006). Employing information communication technologies to enhance qualitative international marketing enquiry. [Article]. International Marketing Review, 23(4), 438-455.

Lomi, A., Larsen, E. R., \& van Ackere, A. (2003). Organization, evolution and performance in neighborhood-based systems Geography and Strategy (Vol. 20, pp. 239-265).

Lopez, L. E., Kundu, S. K., \& Ciravegna, L. (2009). Born global or born regional? Evidence from an exploratory study in the Costa Rican software industry. [Article]. Journal of International Business Studies, 40(7), 1228-1238. 
Lu, J. W., \& Beamish, P. W. (2001). The internationalization and performance of SMEs. [Article]. Strategic Management Journal, 22(6-7), 565-586.

Lu, J. W., \& Beamish, P. W. (2006). Partnering strategies and performance of SMEs' international joint ventures. [Article]. Journal of Business Venturing, 21(4), 461-486.

Manolova, T. S., Manev, I. M., \& Gyoshev, B. S. In good company: The role of personal and inter-firm networks for new-venture internationalization in a transition economy. [Article]. Journal of World Business, 45(3), 257-265.

March, J. G. (1988). Variable Risk Preferences and Adaptive Aspirations Journal of Economic Behavior and Organization, 9, 20.

March, J. G. (1991). Exploitation and Exploration in Organizational Learning. Organization Science, 2(1), 18.

Martin-Tapia, I., Aragon-Correa, J. A., \& Rueda-Manzanares, A. Environmental strategy and exports in medium, small and micro-enterprises. [Article]. Journal of World Business, 45(3), 266-275.

Maskell, P., \& Malmberg, A. (2007). Myopia, knowledge development and cluster evolution. Journal of Economic Geography, 7(5), 603-618.

Mathews, J. A., \& Zander, I. (2007). The international entrepreneurial dynamics of accelerated internationalisation. [Review]. Journal of International Business Studies, 38(3), 387-403.

Miller, D., \& Friesen, P. H. (1986). Porters (1980) generic strategies and performance - an empirical- examination with american data .2. performance implications. [Article]. Organization Studies, 7(3), 255-261.

Mudambi, R., \& Zahra, S. A. (2007). The survival of international new ventures. [Review]. Journal of International Business Studies, 38(2), 333-352. 
Murphy, G. B., Trailer, J. W., \& Hill, R. C. (1996). Measuring performance in entrepreneurship research. [Article]. Journal of Business Research, 36(1), 15-23.

Musteen, M., Francis, J., \& Datta, D. K. The influence of international networks on internationalization speed and performance: A study of Czech SMEs. [Article]. Journal of World Business, 45(3), 197-205.

Nadkarni, S., \& Perez, P. D. (2007). Prior conditions and early international commitment: the mediating role of domestic mindset. [Article]. Journal of International Business Studies, $38(1), 160-176$.

Nahapiet, J., \& Ghoshal, S. (1998). Social Capital, Intellectual Capital and The Organizational Advantage. Academy of Management Review, 23(2), 25.

Nelson, R. R., \& Winter, S. G. (1982). The Schumpeterian tradeoff revisited. [Article]. American Economic Review, 72(1), 114-132.

Nohria, N., \& Ghoshal, S. (1997). The differentiated Network: organizing multinational corporations for value creation. San Francisco: Jossey-Bass Publishers.

Nordman, E. R., \& Melen, S. (2008). The impact of different kinds of knowledge for the internationalization process of Born Globals in the biotech business. [Article]. Journal of World Business, 43(2), 171-185.

Numagami, T. (1998). The infeasibility of invariant laws in management studies: A reflective dialogue in defense of case studies. [Article]. Organization Science, 9(1), 2-15.

O'Reilly, C. A., \& Tushman, M. L. (2004). The ambidextrous organisation. [Article]. Harvard Business Review, 82(4), 74-+. 
Olson, E. M., Walker, O. C., \& Ruekert, R. W. (1995). Organizing for effective new product development - the moderating role of product innovativeness. [Article]. Journal of Marketing, 59(1), 48-62.

Oviatt, B. M., \& McDougall, P. P. (1994). Toward a Theory of International New Ventures. [Article]. Journal of International Business Studies, 25(1), 45-64.

Oviatt, B. M., \& McDougall, P. P. (2005). Defining international entrepreneurship and modeling the speed of internationalization. [Article]. Entrepreneurship Theory and Practice, 29(5), $537-553$.

Parkhe, A. (1993). Messy research, methodological predispositions, and theory development in international joint ventures. [Review]. Academy of Management Review, 18(2), 227-268.

Penrose, E. (1959). The Theory of the Growth of the Firm, . Oxford: Basil Blackwell

Porter, M. E. (1998). Clusters and the new economics of competition. [Article]. Harvard Business Review, 76(6), 77-+.

Porter, M. E. (2000). Location, competition, and economic development: Local clusters in a global economy. Economic Development Quarterly, 14(1), 15-34.

Powell, W. W., Koput, K. W., \& Smith-Doerr, L. (1996). Interorganizaitonal Collaboration and the Locus of Innovation: Network of Learning in Biotechnology. Administrative Science Quarterly, 41(1), 30.

Presutti, M., Boari, C., \& Fratocchi, L. (2007). Knowledge acquisition and the foreign development of high-tech start-ups: A social capital approach. [Article]. International Business Review, 16(1), 23-46. 
Qian, G. M. (2002). Multinationality, product diversification, and profitability of emerging US small- and medium-sized enterprises. [Review]. Journal of Business Venturing, 17(6), 611-633.

Raisch, S., Birkinshaw, J., Probst, G., \& Tushman, M. L. (2009). Organizational Ambidexterity: Balancing Exploitation and Exploration for Sustained Performance. [Article]. Organization Science, 20(4), 685-695.

Rialp, A., Rialp, J., \& Knight, G. A. (2005). The phenomenon of early internationalizing firms: what do we know after a decade (1993-2003) of scientific inquiry? [Article]. International Business Review, 14(2), 147-166.

Rivkin, J. W. (2000). Imitation of complex strategies. [Article]. Management Science, 46(6), 824-844.

Rosenkopf, L., \& Nerkar, A. (2001). Beyond local search: Boundary-spanning, exploration, and impact in the optical disk industry. [Article]. Strategic Management Journal, 22(4), 287306.

Rosenthal, S. S., \& Strange, W. C. (2001). The determinants of agglomeration. Journal of Urban Economics, 50(2), 191-229.

Rothaermel, F. T., \& Alexandre, M. T. (2009). Ambidexterity in Technology Sourcing: The Moderating Role of Absorptive Capacity. [Review]. Organization Science, 20(4), 759780.

Rothaermel, F. T., \& Deeds, D. L. (2004). Exploration and exploitation alliances in biotechnology: A system of new product development. [Article]. Strategic Management Journal, 25(3), 201-221. 
Sapienza, H. J., Autio, E., George, G., \& Zahra, S. A. (2006). A capabilities perspective on the effects of early internationalization on firm survival and growth. [Article]. Academy of Management Review, 31(4), 914-933.

Schumpter, J. (1934). Capitalism, socialism, and democracy. New York: Harper \& Row.

SEC EDGAR System. from U.S Securities and Exchange Commission:

Shane, S., \& Venkataraman, S. (2000). The promise of entrepreneurship as a field of research. [Article]. Academy of Management Review, 25(1), 217-226.

Sidhu, J. S., Commandeur, H. R., \& Volberda, H. W. (2007). The multifaceted nature of exploration and exploitation: Value of supply, demand, and spatial search for innovation. [Review]. Organization Science, 18(1), 20-38.

Singh, D. A., Gaur, A. S., \& Schmid, F. P. Corporate Diversification, TMT Experience, and Performance. [Article]. Management International Review, 50(1), 35-56.

Slevin, D. P., \& Covin, J. G. (1997). Strategy formation patterns, performance, and the significance of context. [Article]. Journal of Management, 23(2), 189-209.

Sorensen, J. B., \& Stuart, T. E. (2000). Aging, obsolescence, and organizational innovation. [Article]. Administrative Science Quarterly, 45(1), 81-112.

Stalk, G., Evans, P., \& Shulman, L. E. (1992). Competing on capabilities - the new rules of corporate-strategy. [Article]. Harvard Business Review, 70(2), 57-69.

Stuart, T. E. (2000). Interorganizational alliances and the performance of firms: A study of growth and innovation rates in a high-technology industry. [Article]. Strategic Management Journal, 21(8), 791-811.

Szulanski, G. (1996). Exploring internal stickiness: Impediments to the transfer of best practice within the firm. Strategic Management Journal, 17, 27-43. 
Tallman, S., \& Fladmoe-Lindquist, K. (2002). Internationalization, globalization, and capabilitybased strategy. [Article]. California Management Review, 45(1), 116-+.

Tallman, S., Jenkins, M., Henry, N., \& Pinch, S. (2004). Knowledge, clusters, and competitive advantage. Academy of Management Review, 29(2), 258-271.

Teece, D. J. (2007). Explicating dynamic capabilities: The nature and microfoundations of (sustainable) enterprise performance. [Review]. Strategic Management Journal, 28(13), 1319-1350.

Teece, D. J., Pisano, G., \& Shuen, A. (1997). Dynamic capabilities and strategic management. [Review]. Strategic Management Journal, 18(7), 509-533.

Tsai, W. (2002). Social Structure of "Coopetition" Within a Multiunit Organization:

Coordination, Competition, and Intraorganizational Knowledge Sharing. Organization Science, 13(2), 12.

Tushman, M. L., \& Oreilly, C. A. (1996). Ambidextrous organizations: Managing evolutionary and revolutionary change. [Article]. California Management Review, 38(4), 8-\&.

Uotila, J., Maula, M., Keil, T., \& Zahra, S. A. (2009). Exploration, exploitation, and financial performance: Analysis of S\&P 500 corporations.[Article]. Strategic Management Journal, 30(2), 221-231.

Uzzi, B. (1997). Social Structure and Competition in Interfirm Networks: The Paradox of Embeddedness. Administrative Science Quarterly, 42(1), 33.

Vanhaverbeke, W., Gilsing, V., Beerkens, B., \& Duysters, G. (2009). The Role of Alliance Network Redundancy in the Creation of Core and Non-core Technologies. [Review]. Journal of Management Studies, 46(2), 215-244. 
Vera, D., \& Crossan, M. (2004). Strategic leadership and organizational learning. [Review]. Academy of Management Review, 29(2), 222-240.

Voss, G. B., Sirdeshmukh, D., \& Voss, Z. G. (2008). The effects of slack resources and environmental threat on product exploration and exploitation. [Article]. Academy of Management Journal, 5l(1), 147-164.

Werner, S. (2002). Recent Developments in International Management Research: A Review of 20 Top Management Journals. Journal of Management, 28(3), 28.

Wernerfelt, B. (1984). A RESOURCE-BASED VIEW OF THE FIRM. [Article]. Strategic Management Journal, 5(2), 171-180.

Westhead, P., Wright, M., \& Ucbasaran, D. (2001). The internationalization of new and small firms: A resource-based view. [Article]. Journal of Business Venturing, 16(4), 333-358.

Whetten, D. A. (1989). What constitutes a theoretical contribution? Academy of Management Review, 14,6 .

Yamakawa, Y., Peng, M. W., \& Deeds, D. L. (2008). What drives new ventures to internationalize from emerging to developed economies? [Review]. Entrepreneurship Theory and Practice, 32(1), 59-82.

Yin, R. (1994). Case Study Research: Design and Methods. Thousand Oaks, CA: Sage.

Yli-Renko, H., Autio, E., \& Sapienza, H. J. (2001). Social capital, knowledge acquisition, and knowledge exploitation in young technology-based firms. Strategic Management Journal, 22(6-7), 587-613.

Zahra, S. A. (2005). A theory of international new ventures: a decade of research. [Article]. Journal of International Business Studies, 36(1), 20-28. 
Zahra, S. A., Ireland, R. D., \& Hitt, M. A. (2000). International expansion by new venture firms: International diversity, mode of market entry, technological learning, and performance. [Review]. Academy of Management Journal, 43(5), 925-950.

Zhou, K. Z., \& Wu, F. Technological Capabilitity, strategic flexibility, and product innovation (vol 31, pg 547, 2010). [Correction]. Strategic Management Journal, 31(6), 688-688.

Zhou, L. (2007). The effects of entrepreneurial proclivity and foreign market knowledge on early internationalization. [Article]. Journal of World Business, 42(3), 281-293.

Zhou, L. X., Barnes, B. R., \& Lu, Y. A. Entrepreneurial proclivity, capability upgrading and performance advantage of newness among international new ventures. [Article]. Journal of International Business Studies, 41(5), 882-905.

Zucchella, A., Palamara, G., \& Denicolai, S. (2007). The drivers of the early internationalization of the firm. [Article]. Journal of World Business, 42(3), 268-280. 


\section{Appendices}

Appendix A All figures included in the dissertation

Figure 1 Conceptual model for international ambidexterity of new ventures

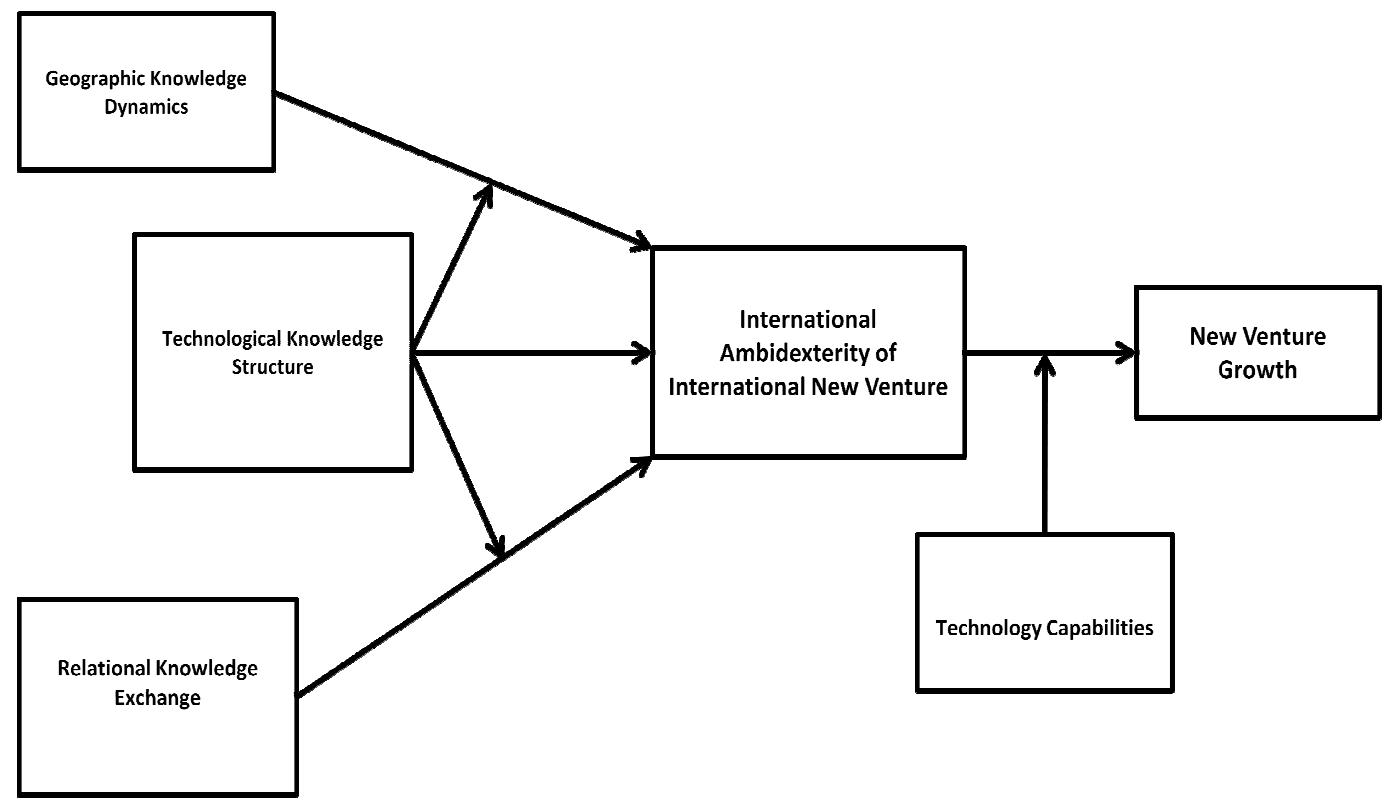


Figure 2 Review frameworks of ambidexterity studies

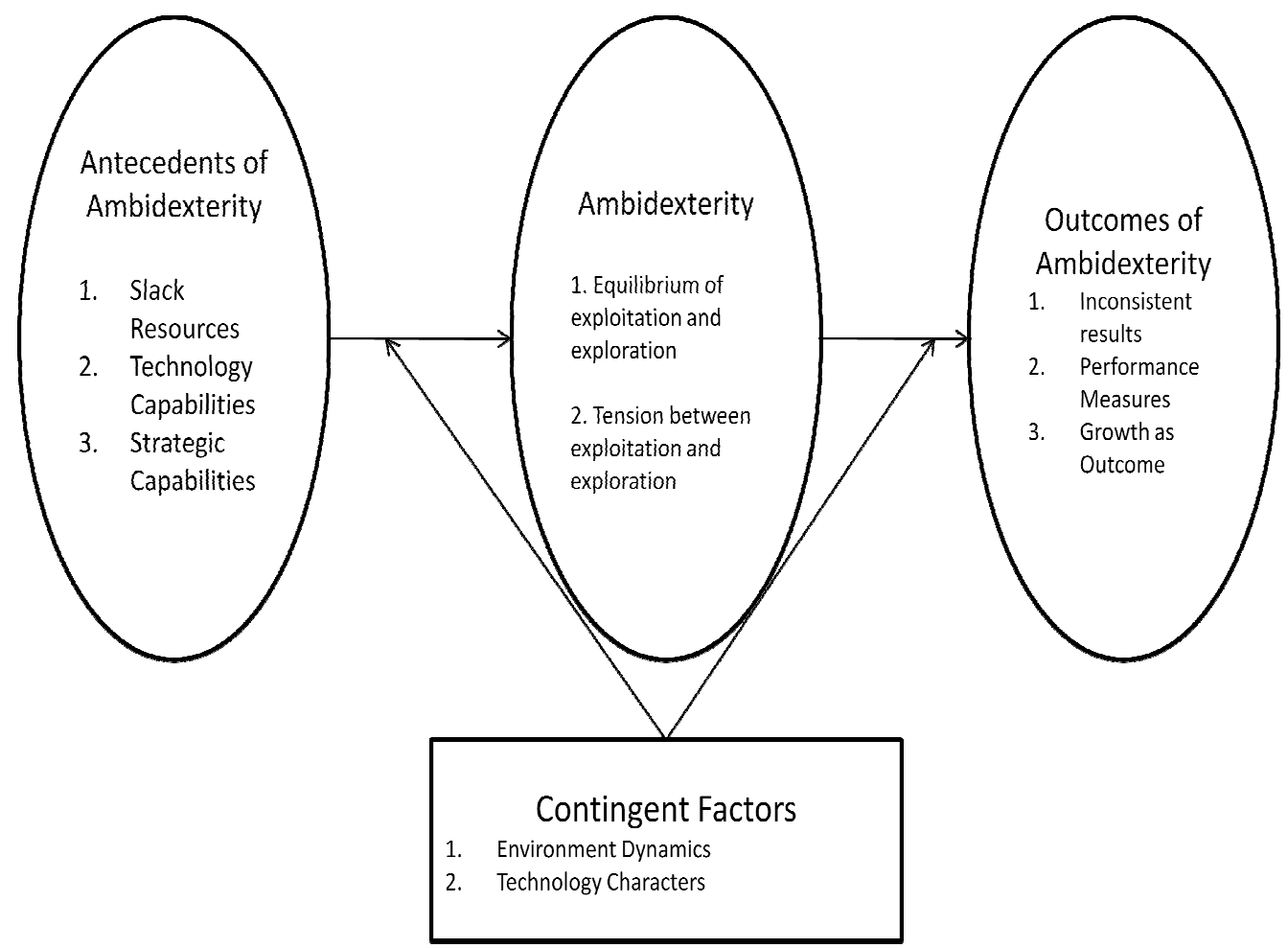




\section{Figure 3 Empirical model for hypotheses testing}

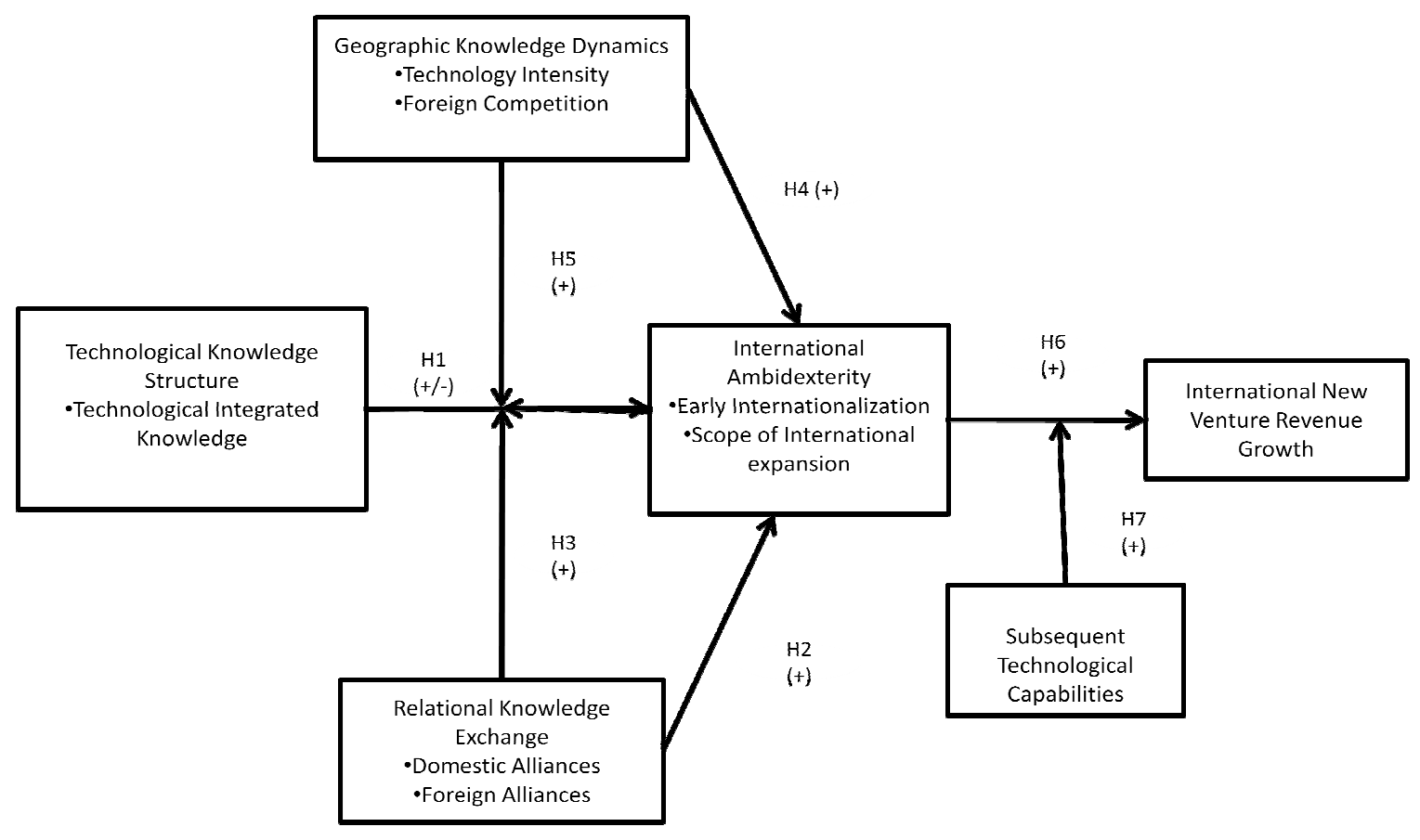


Figure 4 Flowchart for data collection

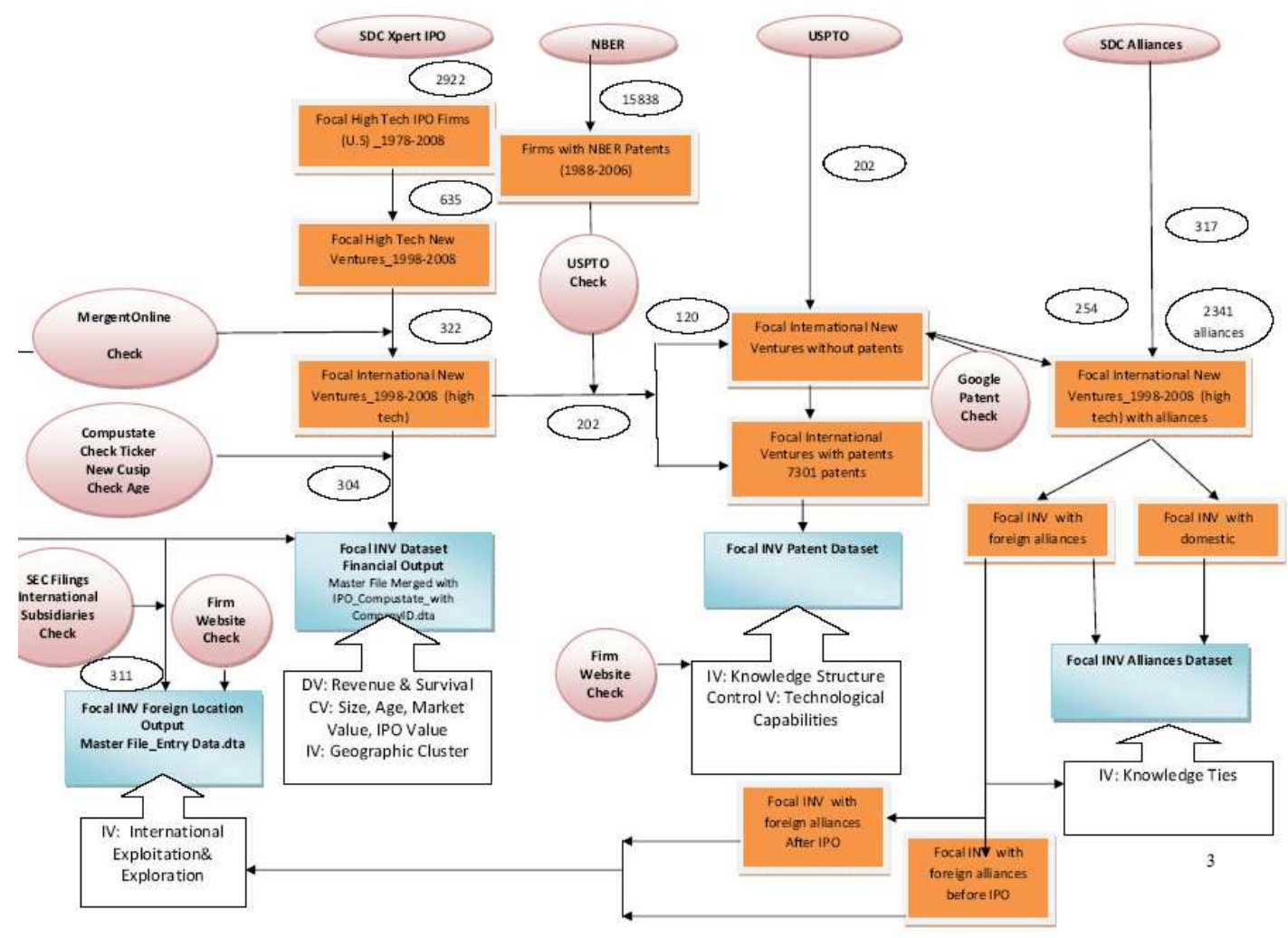


Figure 5 LOG value of growth variables
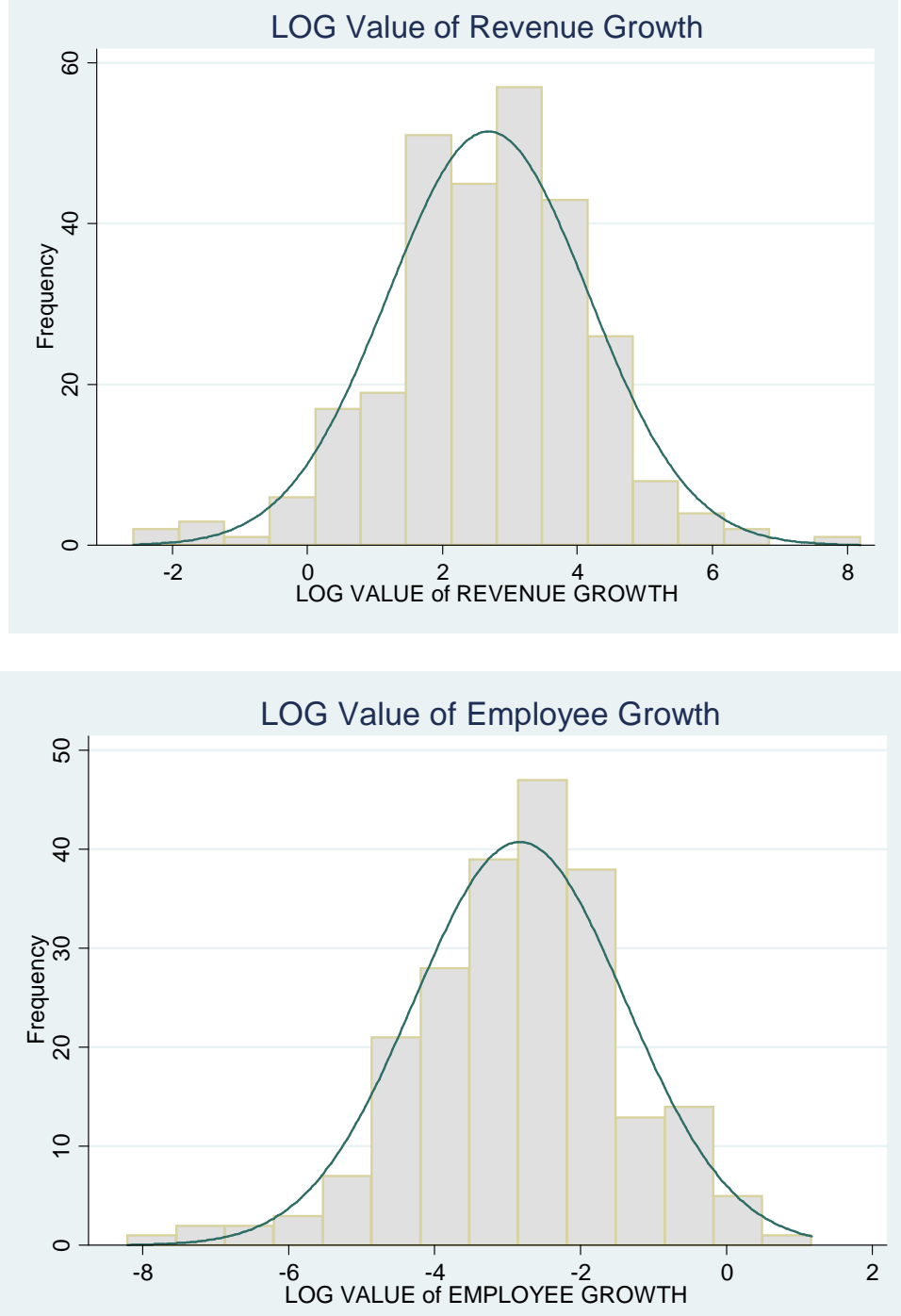
Appendix B Literature review on exploitation, exploration and ambidexterity

\begin{tabular}{|c|c|c|c|c|c|c|c|c|c|c|}
\hline Study & $\begin{array}{l}\text { Research } \\
\text { Question }\end{array}$ & Related Lit & $\begin{array}{l}\text { Research } \\
\text { Setting }\end{array}$ & Method & \multicolumn{3}{|c|}{$\begin{array}{c}\text { Exploitation, Exploration \& } \\
\text { Ambidexterity }\end{array}$} & $\begin{array}{l}\text { Antecedents, } \\
\text { Outcomes or } \\
\text { Contingent }\end{array}$ & $\begin{array}{l}\text { Measures for } \\
\text { Exploitation } \\
\text { and }\end{array}$ & Results \\
\hline $\begin{array}{l}\text { Hoang, \& } \\
\text { Rothaermel } \\
\text { _2010 (SMJ) }\end{array}$ & $\begin{array}{l}\text { Does alliance } \\
\text { exploitation } \\
\text { experience have } \\
\text { positive effects on } \\
\text { R\&D project } \\
\text { performance, } \\
\text { while alliance } \\
\text { exploration } \\
\text { experience has } \\
\text { negative effects? }\end{array}$ & $\begin{array}{l}\text { Dynamic } \\
\text { Capabilities, } \\
\text { Absorptive } \\
\text { capacity }\end{array}$ & $\begin{array}{l}\text { A dataset of } \\
412 \text { R\&D } \\
\text { projects in } \\
\text { biotechnology } \\
\text { conducted by } \\
\text { large } \\
\text { pharmaceutical } \\
\text { companies } \\
\text { between } 1980 \\
\text { and } 2000\end{array}$ & $\begin{array}{l}\text { A competing } \\
\text { risk event } \\
\text { history model }\end{array}$ & $\begin{array}{l}\text { Exploitation: } \\
\text { percentage of } \\
\text { licensing and } \\
\text { manufacture } \\
\text { agreements } \\
\text { within the } \\
\text { biotech field }\end{array}$ & $\begin{array}{l}\text { Exploration: } \\
\text { percentage of } \\
\text { R\&D alliances } \\
\text { entered into by } \\
\text { the pharmaceu- } \\
\text { tical firm in the } \\
\text { biotech field }\end{array}$ & & $\begin{array}{l}\text { Outcomes: } \\
\text { Performance: } \\
\text { time to drug } \\
\text { approval of } \\
\text { biotech R\&D } \\
\text { projects } \\
\text { undertaken by } \\
\text { established } \\
\text { pharmaceutical } \\
\text { firms } \\
\text { Contingent } \\
\text { Factors: } \\
\text { interactions } \\
\text { between internal } \\
\text { capabilities and } \\
\text { external alliances }\end{array}$ & $\begin{array}{l}\text { Internal } \\
\text { exploration and } \\
\text { exploitation } \\
\text { experience } \\
\text { based on a firm's } \\
\text { past R\&D } \\
\text { efforts } \\
\text { (exploration) } \\
\text { and product } \\
\text { sales } \\
\text { (exploitation). }\end{array}$ & $\begin{array}{l}\text { They find support for } \\
\text { theoretical model. They } \\
\text { further posit that an } \\
\text { internal exploration } \\
\text { competence allows firms } \\
\text { to leverage their external } \\
\text { exploitation experience } \\
\text { more fully. In contrast, } \\
\text { when firms combine } \\
\text { internal exploitation } \\
\text { experience with external } \\
\text { exploration experience, } \\
\text { the negative effects on } \\
\text { R\&D project performance } \\
\text { become more pronounced }\end{array}$ \\
\hline $\begin{array}{l}\text { Fang, Lee, and } \\
\text { Schilling_- } \\
2010(\text { OS) }\end{array}$ & $\begin{array}{l}\text { 1) How firms can } \\
\text { better maintain } \\
\text { the balance of } \\
\text { exploration and } \\
\text { exploitation. } \\
\text { 2)Does a semi- } \\
\text { isolated subgroup } \\
\text { structure improve } \\
\text { the balance of } \\
\text { exploration and } \\
\text { exploitation, } \\
\text { leading } \\
\text { to superior } \\
\text { performance? } \\
\text { 3) If this structure } \\
\text { is beneficial, any } \\
\text { other factors? }\end{array}$ & $\begin{array}{l}\text { Org Learning, } \\
\text { Dynamic } \\
\text { Capabilities, } \\
\text { Contingency } \\
\text { theory }\end{array}$ & $\begin{array}{l}\text { Simulate } \\
\text { systematically } \\
\text { varying the } \\
\text { interaction } \\
\text { pattern } \\
\text { between } \\
\text { individuals to } \\
\text { explore how } \\
\text { the degree of } \\
\text { subgroup } \\
\text { isolation and } \\
\text { intergroup } \\
\text { connectivity } \\
\text { influences } \\
\text { organizational } \\
\text { learning }\end{array}$ & Simulation & $\begin{array}{l}\text { Exploitation: } \\
\text { use and } \\
\text { propagation } \\
\text { of known } \\
\text { adaptations }\end{array}$ & $\begin{array}{l}\text { Exploration: } \\
\text { search for new, } \\
\text { useful } \\
\text { adaptations }\end{array}$ & $\begin{array}{l}\text { Exploitation } \\
\text { and } \\
\text { Exploration } \\
\text { Balance }\end{array}$ & $\begin{array}{l}\text { Antecedents: } \\
\text { organizational } \\
\text { structure } \\
\text { Outcome: long } \\
\text { term learning } \\
\text { performance } \\
\text { Contingent } \\
\text { factors: } \\
\text { environmental } \\
\text { dynamics and } \\
\text { personnel } \\
\text { turnover }\end{array}$ & $\begin{array}{l}\text { Balance of } \\
\text { exploitation and } \\
\text { exploration-> } \\
\text { performance } \\
\text { (tradeoff) } \\
\text { Contingent } \\
\text { Factors: problem } \\
\text { complexity, } \\
\text { environmental } \\
\text { dynamism, and } \\
\text { personnel } \\
\text { turnover }\end{array}$ & $\begin{array}{l}\text { An organization divided } \\
\text { into semi-isolated } \\
\text { subgroups may help strike } \\
\text { balance of exploitation } \\
\text { and exploration } \\
\text { Moderate levels of cross- } \\
\text { group linking lead to the } \\
\text { highest equilibrium } \\
\text { performance by enabling } \\
\text { superior ideas to diffuse } \\
\text { across groups without } \\
\text { reducing organizational } \\
\text { diversity too quickly. }\end{array}$ \\
\hline $\begin{array}{l}\text { Zhou and Wu } \\
\text { _2010 (SMJ) }\end{array}$ & $\begin{array}{l}\text { What is the role of } \\
\text { technological } \\
\text { capability in } \\
\text { product } \\
\text { innovation? }\end{array}$ & $\begin{array}{l}\text { Absorptive } \\
\text { Capacity and } \\
\text { Organization } \\
\text { Inertia }\end{array}$ & $\begin{array}{l}\text { Chinese } \\
\text { Settings in } \\
\text { High Tech } \\
\text { Industries }\end{array}$ & $\begin{array}{l}\text { Survey- } \\
\text { Based } \\
\text { Quantitative }\end{array}$ & $\begin{array}{l}\text { Exploitation: } \\
\text { use and } \\
\text { refinement of } \\
\text { existing } \\
\text { knowledge } \\
\text { and skills in } \\
\text { product }\end{array}$ & $\begin{array}{l}\text { Exploration: the } \\
\text { search and } \\
\text { pursuit of } \\
\text { completely new } \\
\text { knowledge and } \\
\text { skills in product } \\
\text { development }\end{array}$ & & $\begin{array}{l}\text { Antecedents: } \\
\text { technological } \\
\text { capabilities }\end{array}$ & $\begin{array}{l}\text { Measures of } \\
\text { exploitation and } \\
\text { exploration from } \\
\text { Atuahene-Gima } \\
\text { (2005); the } \\
\text { items reflect the } \\
\text { extent }\end{array}$ & $\begin{array}{l}\text { The findings support that } \\
\text { though technological } \\
\text { capability fosters } \\
\text { exploitation at an } \\
\text { accelerating rate, it has an } \\
\text { inverted U-shaped } \\
\text { relationship with }\end{array}$ \\
\hline
\end{tabular}




\begin{tabular}{|c|c|c|c|c|c|c|c|c|c|c|}
\hline & & & & & development & & & & $\begin{array}{l}\text { to which a firm } \\
\text { uses existing or } \\
\text { explores new } \\
\text { knowledge and } \\
\text { technologies in } \\
\text { its product } \\
\text { development }\end{array}$ & $\begin{array}{l}\text { exploration. Strategic } \\
\text { flexibility strengthens the } \\
\text { positive effects of } \\
\text { technological capability } \\
\text { on exploration,. }\end{array}$ \\
\hline $\begin{array}{l}\text { Anand, } \\
\text { Mesquita, and } \\
\text { Vassolo_2009 } \\
\text { (AMJ) }\end{array}$ & $\begin{array}{l}\text { Would } \\
\text { multimarket } \\
\text { contact leads to } \\
\text { the same } \\
\text { behavioral } \\
\text { changes in } \\
\text { exploration as it } \\
\text { does in } \\
\text { exploitation? }\end{array}$ & $\begin{array}{l}\text { Multimarket } \\
\text { Competition, } \\
\text { Competitive } \\
\text { Dynamics }\end{array}$ & $\begin{array}{l}\text { Analyses of } \\
\text { biopharmaceut } \\
\text { ical firms' } \\
\text { competitive } \\
\text { dynamics from } \\
1989 \text { to } 1999\end{array}$ & $\begin{array}{l}\text { Quantitative } \\
\text { Study }\end{array}$ & $\begin{array}{l}\text { Exploitation: } \\
\text { entry and exit } \\
\text { as the events } \\
\text { of starting } \\
\text { and ceasing } \\
\text { sales } \\
\text { activities of } \\
\text { existing } \\
\text { products }\end{array}$ & $\begin{array}{l}\text { Exploration: } \\
\text { entry and exit, } \\
\text { as the events of } \\
\text { investing in or } \\
\text { divesting from } \\
\text { research for a } \\
\text { new- product } \\
\text { technology that } \\
\text { may or may not } \\
\text { lead to a viable } \\
\text { product in the } \\
\text { future }\end{array}$ & & $\begin{array}{l}\text { Antecedents: } \\
\text { multi-markets } \\
\text { Competition } \\
\text { Outcomes: new } \\
\text { products } \\
\text { development }\end{array}$ & $\begin{array}{l}\text { Multimarket } \\
\text { contact have } \\
\text { investigated } \\
\text { "exploitation" } \\
\text { rather than } \\
\text { "exploration" } \\
\text { activities. }\end{array}$ & $\begin{array}{l}\text { They found that } \\
\text { multimarket contact in } \\
\text { exploration leads to } \\
\text { competitive entry and exit } \\
\text { in exploitation, but not } \\
\text { vice verse } \\
\text { They propose that, } \\
\text { although in } \text { exploitation, } \\
\text { firms seek to optimize } \\
\text { multimarket contact based } \\
\text { on mutual forbearance } \\
\text { benefits, in exploration, } \\
\text { firms instead seek to } \\
\text { reduce uncertainties } \\
\text { through mimetic entry and } \\
\text { exit. }\end{array}$ \\
\hline $\begin{array}{l}\text { Rothaermel\& } \\
\text { Alexandre_- } \\
2009 \text { (OS) }\end{array}$ & \begin{tabular}{|l} 
Four possible \\
combinations of \\
exploration and \\
exploitation show \\
a curvilinear \\
relationship \\
between a firm's \\
technology \\
sourcing mix and \\
its performance
\end{tabular} & $\begin{array}{l}\text { Ambidexterity } \\
\text { and Absorptive } \\
\text { Capacity }\end{array}$ & $\begin{array}{l}\text { A random, } \\
\text { multi-industry } \\
\text { sample of U.S. } \\
\text { manufacturing } \\
\text { companies }\end{array}$ & $\begin{array}{l}\text { Quantitative } \\
\text { Study }\end{array}$ & $\begin{array}{l}\text { Exploitation: } \\
\text { Internal and } \\
\text { External, } \\
\text { Known } \\
\text { technology } \\
\text { and Radical } \\
\text { Technology }\end{array}$ & $\begin{array}{l}\text { Exploration: } \\
\text { Internal and } \\
\text { External, } \\
\text { Known } \\
\text { technology and } \\
\text { Radical } \\
\text { Technology }\end{array}$ & $\begin{array}{l}\text { Combination } \\
\text { of four types } \\
\text { of } \\
\text { exploitation } \\
\text { and } \\
\text { exploration } \\
\text { combinations }\end{array}$ & $\begin{array}{l}\text { Antecedents: } \\
\text { Internal } \\
\text { Capabilities and } \\
\text { External } \\
\text { Knowledge } \\
\text { Sourcing interact } \\
\text { with each other to } \\
\text { achieve } \\
\text { performance }\end{array}$ & $\begin{array}{l}\text { Internal and } \\
\text { External, } \\
\text { Known } \\
\text { technology and } \\
\text { Radical } \\
\text { Technology }\end{array}$ & $\begin{array}{l}\text { Support is found that the } \\
\text { relationship between } \\
\text { technology sourcing mix } \\
\text { and firm performance is } \\
\text { an inverted U-shape. } \\
\text { Moreover, higher levels of } \\
\text { absorptive capacity allow } \\
\text { a firm to more fully } \\
\text { capture the benefits } \\
\text { resulting from } \\
\text { ambidexterity in } \\
\text { technology sourcing }\end{array}$ \\
\hline $\begin{array}{l}\text { Andriopoulo } \\
\text { and } \\
\text { Lewis._2009 } \\
\text { (OS) }\end{array}$ & $\begin{array}{l}\text { Ambidextrous } \\
\text { organizations } \\
\text { excel at exploiting } \\
\text { and at exploring } \\
\text { Architectural } \\
\text { ambidexterity } \\
\text { proposes dual } \\
\text { structures and } \\
\text { strategies to } \\
\text { differentiate } \\
\text { efforts, focusing } \\
\text { actors on one or } \\
\text { the other form of } \\
\text { innovation. }\end{array}$ & $\begin{array}{l}\text { Technology } \\
\text { Innovation }\end{array}$ & \begin{tabular}{|l} 
Five \\
Companies
\end{tabular} & Case Study & & & $\begin{array}{l}\text { Capabilities } \\
\text { to solve the } \\
\text { tension of } \\
\text { exploitation } \\
\text { and } \\
\text { exploration }\end{array}$ & & & $\begin{array}{l}\text { More specifically, they } \\
\text { present nested paradoxes } \\
\text { of innovation: strategic } \\
\text { intent (profit- } \\
\text { breakthroughs), customer } \\
\text { orientation (tight-loose } \\
\text { coupling), and personal } \\
\text { drivers (discipline- } \\
\text { passion). Building from } \\
\text { innovation and paradox } \\
\text { literature, they theorize } \\
\text { how integration and } \\
\text { differentiation tactics help } \\
\text { manage these interwoven } \\
\text { paradoxes and fuel } \\
\text { virtuous cycles of } \\
\text { ambidexterity. }\end{array}$ \\
\hline
\end{tabular}




\begin{tabular}{|c|c|c|c|c|c|c|c|c|c|c|}
\hline $\begin{array}{l}\text { Uotila, Maula, } \\
\text { Keil and } \\
\text { Zahra_2009 } \\
\text { (SMJ) }\end{array}$ & $\begin{array}{l}\text { Established firms } \\
\text { need to balance } \\
\text { exploration } \text { and } \\
\text { exploitation } \\
\text { activities in order } \\
\text { to achieve } \\
\text { superior } \\
\text { performance. And } \\
\text { the optimal } \\
\text { balance between } \\
\text { exploration and } \\
\text { exploitation } \\
\text { depends upon } \\
\text { environmental } \\
\text { conditions }\end{array}$ & & $\begin{array}{l}1989-2004 \text { for } \\
279 \\
\text { manufacturing } \\
\text { firms in the } \\
\text { 1989 Standard } \\
\text { \& Poor's 500 } \\
\text { index }\end{array}$ & $\begin{array}{l}\text { Generalized } \\
\text { Method } \\
\text { of Moments } \\
\text { (GMM) } \\
\text { methodology }\end{array}$ & Exploitation & Exploration & $\begin{array}{l}\text { Balance of } \\
\text { exploitation } \\
\text { and } \\
\text { exploration }\end{array}$ & $\begin{array}{l}\text { Outcome: } \\
\text { longitudinal } \\
\text { Study on } \\
\text { performance } \\
\text { Contingent } \\
\text { factors: industrial } \\
\text { dynamism }\end{array}$ & $\begin{array}{l}\text { Event coding of } \\
\text { texts } \\
\text { published news } \\
\text { articles and } \\
\text { newswires from } \\
\text { the Factiva } \\
\text { database. } \\
\text { exploratory and } \\
\text { exploitative } \\
\text { words per } \\
\text { company-year. } \\
\text { a key word in } \\
\text { context (KWIC) } \\
\text { analysis }\end{array}$ & $\begin{array}{l}\text { An inverted U-shaped } \\
\text { relationship between the } \\
\text { relative share of } \\
\text { explorative orientation } \\
\text { and financial } \\
\text { performance. This } \\
\text { relationship is positively } \\
\text { moderated by the R\&D } \\
\text { intensity of the industry in } \\
\text { which the firm operates. }\end{array}$ \\
\hline $\begin{array}{l}\text { Bierly, } \\
\text { Damanpour, } \\
\text { and Santoro } \\
(2009) \_J M S\end{array}$ & $\begin{array}{l}\text { Various } \\
\text { organizational } \\
\text { conditions that are } \\
\text { proposed to } \\
\text { influence a firm's } \\
\text { ability to apply } \\
\text { external } \\
\text { knowledge for } \\
\text { explorative and } \\
\text { exploitative } \\
\text { innovations. }\end{array}$ & $\begin{array}{l}\text { Absorptive } \\
\text { capacity }\end{array}$ & $\begin{array}{l}\text { Firms in } \\
\text { industries that } \\
\text { frequently } \\
\text { work with } \\
\text { university } \\
\text { research } \\
\text { Centers } \\
\text { (URCs) and } \\
\text { from publicly } \\
\text { available } \\
\text { sources }\end{array}$ & $\begin{array}{l}\text { Survey- } \\
\text { Based } \\
\text { Quantitative } \\
\text { OLS } \\
\text { Regression }\end{array}$ & $\begin{array}{l}\text { Exploitation: } \\
\text { Modification } \\
\text { and } \\
\text { Improvement }\end{array}$ & $\begin{array}{l}\text { Exploration: } \\
\text { New products } \\
\text { and processes }\end{array}$ & & $\begin{array}{l}\text { Antecedents: } \\
\text { Technological } \\
\text { Capabilities and } \\
\text { Strategic } \\
\text { Capabilities } \\
\text { Contingent } \\
\text { factors: } \\
\text { knowledge } \\
\text { tacitness }\end{array}$ & $\begin{array}{l}\text { Exploration : the } \\
\text { application of } \\
\text { knowledge from } \\
\text { URCs for the } \\
\text { development of } \\
\text { new products } \\
\text { and processes } \\
\text { and the activities } \\
\text { that lead to } \\
\text { them; } \\
\text { Exploitation the } \\
\text { application of } \\
\text { knowledge from } \\
\text { URCs for the } \\
\text { modification and } \\
\text { improvement of } \\
\text { products and } \\
\text { processes. }\end{array}$ & $\begin{array}{l}\text { Predictors of exploration } \\
\text { and exploitation of } \\
\text { external knowledge differ. } \\
\text { Technological relatedness, } \\
\text { a common measure of } \\
\text { absorptive capacity, is } \\
\text { negatively associated with } \\
\text { the application of external } \\
\text { knowledge to explorative } \\
\text { innovations, indicating } \\
\text { that knowledge from more } \\
\text { distant sources is applied } \\
\text { more to exploration. }\end{array}$ \\
\hline $\begin{array}{l}\text { Vanhaverbeke, } \\
\text { Gilsing, } \\
\text { Beerkens, and } \\
\text { Duysters_2009 } \\
\text { (JMS) }\end{array}$ & $\begin{array}{l}\text { How two types of } \\
\text { redundancy in a } \\
\text { focal firm's ego } \\
\text { network affect its } \\
\text { ability to create } \\
\text { new technologies } \\
\text { in its technology } \\
\text { core areas } \\
\text { (exploitation) } \\
\text { and/or non-core } \\
\text { areas } \\
\text { (exploration)? } \\
\end{array}$ & & $\begin{array}{l}\text { Three different } \\
\text { industry } \\
\text { settings: } \\
\text { chemicals, } \\
\text { motor vehicles, } \\
\text { and } \\
\text { pharmaceutical }\end{array}$ & & $\begin{array}{l}\text { Technology } \\
\text { exploitation }\end{array}$ & $\begin{array}{l}\text { Technology } \\
\text { exploration }\end{array}$ & & $\begin{array}{l}\text { Antecedents: } \\
\text { networks }\end{array}$ & & $\begin{array}{l}\text { Individual firms can boost } \\
\text { both types of innovative } \\
\text { output by shaping the } \\
\text { degree of redundancy in } \\
\text { their local alliance } \\
\text { network, but the way in } \\
\text { which this should be done } \\
\text { differs between the } \\
\text { creation of core and non- } \\
\text { core technologies. }\end{array}$ \\
\hline $\begin{array}{l}\text { Im, and } \\
\text { Rai._2008 } \\
\text { (MS) }\end{array}$ & $\begin{array}{l}\text { Can the boundary } \\
\text { condition for } \\
\text { ambidextrous } \\
\text { learning be } \\
\text { extended from } \\
\text { firms to long-term } \\
\text { inter- } \\
\text { organizational } \\
\text { relationships? }\end{array}$ & & $\begin{array}{l}\text { Data collected } \\
\text { from both } \\
\text { account } \\
\text { managers at } \\
\text { customer firms }\end{array}$ & $\begin{array}{l}\text { Survey- } \\
\text { Based } \\
\text { Quantitative }\end{array}$ & $\begin{array}{l}\text { Exploitation: } \\
\text { knowledge } \\
\text { sharing }\end{array}$ & $\begin{array}{l}\text { Exploration: } \\
\text { knowledge } \\
\text { creation }\end{array}$ & $\begin{array}{l}\text { Ontological } \\
\text { of } \\
\text { exploitation } \\
\text { and } \\
\text { exploration }\end{array}$ & $\begin{array}{l}\text { Outcomes: Inter- } \\
\text { firm relationship } \\
\\
\text { Contingent } \\
\text { Factors: } \\
\text { relationship } \\
\text { duration }\end{array}$ & $\begin{array}{l}\text { A leading supply } \\
\text { chain vendor } \\
\text { and explorative } \\
\text { and exploitative } \\
\text { knowledge } \\
\text { sharing account } \\
\text { managers at the } \\
\text { vendor firm } \\
\text { responsible. }\end{array}$ & $\begin{array}{l}\text { Exploratory and } \\
\text { exploitative knowledge } \\
\text { sharing lead to } \\
\text { relationship performance } \\
\text { gains, that such sharing is } \\
\text { enabled by the } \\
\text { ambidextrous } \\
\text { management of the } \\
\text { relationship. . }\end{array}$ \\
\hline
\end{tabular}




\begin{tabular}{|c|c|c|c|c|c|c|c|c|c|c|}
\hline $\begin{array}{l}\text { Voss, } \\
\text { Sirdeshmukh, } \\
\text { And Voss - } \\
2008 \text { (AMJ) }\end{array}$ & $\begin{array}{l}\text { How slack } \\
\text { resources interact } \\
\text { with } \\
\text { environmental } \\
\text { threat appraisal to } \\
\text { influence product } \\
\text { exploration and } \\
\text { exploitation }\end{array}$ & $\begin{array}{l}\text { Prospect } \\
\text { Theory and } \\
\text { Rigidity } \\
\text { Theory }\end{array}$ & $\begin{array}{l}\text { In a U.S. } \\
\text { sample of } \\
\text { nonprofit } \\
\text { professional } \\
\text { theaters }\end{array}$ & $\begin{array}{l}\text { Survey- } \\
\text { Based } \\
\text { Quantitative } \\
\text { Analysis } \\
\text { OLS }\end{array}$ & Exploitation & Exploration & & $\begin{array}{l}\text { Contingent } \\
\text { Factors: } \\
\text { environmental } \\
\text { threat } \\
\text { Antecedents: } \\
\text { slack resources }\end{array}$ & \begin{tabular}{|l|} 
Measurements \\
based on \\
questionnaires \\
of keywords \\
representing \\
exploitation and \\
exploration \\
\end{tabular} & $\begin{array}{l}\text { Effects of environmental } \\
\text { threat are largely } \\
\text { contingent on the nature } \\
\text { of available resources. } \\
\text { These results offer } \\
\text { implications for } \\
\text { organizations seeking to } \\
\text { align product exploration } \\
\text { and exploitation with } \\
\text { strategic intent. }\end{array}$ \\
\hline $\begin{array}{l}\text { Lin, Yang and } \\
\text { Demirkan_- } \\
2008 \text {,MS }\end{array}$ & $\begin{array}{l}\text { When } \\
\text { ambidexterity in } \\
\text { alliances } \\
\text { approaches } \\
\text { impact firm } \\
\text { performance. } \\
\text { (Specifically, } \\
\text { structure based } \\
\text { ambidexterity) } \\
\text { this relationship is } \\
\text { moderated by firm } \\
\text { size, environment } \\
\text { uncertainty, and } \\
\text { network } \\
\text { characteristics }\end{array}$ & & $\begin{array}{l}\text { A sample of } \\
\text { firms between } \\
\text { 1988-1995 was } \\
\text { selected, } \\
\text { Compustat. } \\
\text { Data from } \\
\text { Moddy's FIS } \\
\text { onlines. }\end{array}$ & Simulation & Exploitation & Exploration & $\begin{array}{l}\text { Complement } \\
\text { ary view of } \\
\text { exploitation } \\
\text { and } \\
\text { exploration }\end{array}$ & $\begin{array}{l}\text { Outcome: firm } \\
\text { performance } \\
\text { Contingent } \\
\text { Factors: } \\
\text { environments, } \\
\text { network interact } \\
\text { with external } \\
\text { relationship }\end{array}$ & $\begin{array}{l}\text { Exploration: if } \\
\text { the index is } \\
\text { between 0.2-0.8. } \\
\text { Alliances } \\
\text { Ambidexterity= } \\
1 \text {. Exploration: } \\
\text { total number of } \\
\text { new partners of } \\
\text { all of a firms' } \\
\text { alliances/ total } \\
\text { of all partners } \\
\text { for a firms' } \\
\text { alliances }\end{array}$ & $\begin{array}{l}\text { Although an ambidextrous } \\
\text { formation of alliances } \\
\text { benefits large firms, a } \\
\text { focused formation of } \\
\text { either exploratory or } \\
\text { exploitative alliances } \\
\text { benefits small firms. In an } \\
\text { uncertain environment an } \\
\text { ambidextrous formation } \\
\text { enhances firm } \\
\text { performance but so does a } \\
\text { focused formation in a } \\
\text { stable environment. a } \\
\text { firm's centrality and } \\
\text { structural hole positions in } \\
\text { network relations can } \\
\text { moderate the relationships } \\
\text { between alliance } \\
\text { formation choices and } \\
\text { firm performance, }\end{array}$ \\
\hline $\begin{array}{l}\text { Kane, and } \\
\text { Alavi_2007 } \\
\text { (OS) }\end{array}$ & $\begin{array}{l}\text { the effects of } \\
\text { information } \\
\text { technology (IT) } \\
\text { on exploration } \\
\text { and exploitation }\end{array}$ & $\begin{array}{l}\text { Organization } \\
\text { Learning }\end{array}$ & & Simulation & Exploitation & Exploration & & $\begin{array}{l}\text { Contingent } \\
\text { Factors: } \\
\text { Environment } \\
\text { Dynamics }\end{array}$ & & $\begin{array}{l}\text { Each of these IT-enabled } \\
\text { learning mechanisms } \\
\text { enable capabilities that } \\
\text { have a distinct effect on } \\
\text { the exploration and } \\
\text { exploitation learning } \\
\text { dynamics in the } \\
\text { organization. And this } \\
\text { effect is dependent on } \\
\text { organizational and } \\
\text { environmental conditions, } \\
\text { as well as on the } \\
\text { interaction effects } \\
\text { between the various } \\
\text { mechanisms when used in } \\
\text { combination with one } \\
\text { another. }\end{array}$ \\
\hline $\begin{array}{l}\text { Tom, Van } \\
\text { Den Bosch, } \\
\text { Henk and } \\
\text { Volberda_2007 } \\
\text { (JMS) }\end{array}$ & $\begin{array}{l}\text { The influence of } \\
\text { managers' } \\
\text { knowledge } \\
\text { inflows on } \\
\text { managers' } \\
\text { exploration and }\end{array}$ & & 136 managers & $\begin{array}{l}\text { Survey- } \\
\text { Based } \\
\text { Quantitative } \\
\text { Hierarchical } \\
\text { Linear } \\
\text { Regression }\end{array}$ & $\begin{array}{l}\text { Exploitation } \\
\text { Activities: } \\
\text { the extent to } \\
\text { which the } \\
\text { manager } \\
\text { engaged in }\end{array}$ & $\begin{array}{l}\text { Exploration } \\
\text { Activities: the } \\
\text { extent to which } \\
\text { a manager } \\
\text { engaged in } \\
\text { exploration }\end{array}$ & & $\begin{array}{l}\text { Antecedents: } \\
\text { knowledge flow }\end{array}$ & $\begin{array}{l}\text { Manager } \\
\text { engaged in } \\
\text { exploration } \\
\text { /exploitation } \\
\text { activities last } \\
\text { year }\end{array}$ & $\begin{array}{l}\text { Top-down knowledge } \\
\text { inflows of managers } \\
\text { positively relate to the } \\
\text { extent to which these } \\
\text { managers conduct } \\
\text { exploitation activities, }\end{array}$ \\
\hline
\end{tabular}

164 


\begin{tabular}{|c|c|c|c|c|c|c|c|c|c|c|}
\hline & $\begin{array}{l}\text { exploitation } \\
\text { activities }\end{array}$ & & & & $\begin{array}{l}\text { exploitation } \\
\text { activities last } \\
\text { year. }\end{array}$ & $\begin{array}{l}\text { activities last } \\
\text { year }\end{array}$ & & & & $\begin{array}{l}\text { while they do not relate to } \\
\text { managers' exploration } \\
\text { activities. Furthermore, as } \\
\text { expected, bottom-up and } \\
\text { horizontal knowledge } \\
\text { inflows of managers } \\
\text { positively relate to these } \\
\text { managers' exploration } \\
\text { activities, while they do } \\
\text { not relate to managers' } \\
\text { exploitation activities }\end{array}$ \\
\hline $\begin{array}{l}\text { Bierly and } \\
\text { Daly._2007 } \\
\text { (ET\&P) }\end{array}$ & $\begin{array}{l}\text { What is the } \\
\text { relationship } \\
\text { between an SME's } \\
\text { knowledge } \\
\text { strategy } \\
\text { (exploration or } \\
\text { exploitation) and } \\
\text { performance, and } \\
\text { the possible } \\
\text { moderating role of } \\
\text { external } \\
\text { environment } \\
\text { variables? }\end{array}$ & & $\begin{array}{l}\text { Sample of } \\
\text { small } \\
\text { manufacturing } \\
\text { firms }\end{array}$ & $\begin{array}{l}\text { Survey- } \\
\text { Based } \\
\text { Quantitative } \\
\text { Study } \\
\text { Hierarchical } \\
\text { Regression }\end{array}$ & $\begin{array}{l}\text { Exploitation } \\
\text { Strategy }\end{array}$ & $\begin{array}{l}\text { Exploration } \\
\text { Strategy }\end{array}$ & & $\begin{array}{l}\text { Outcome: } \\
\text { performance } \\
\text { Moderator: } \\
\text { environmental } \\
\text { variables }\end{array}$ & $\begin{array}{l}\text { Whether more } \\
\text { of firms } \\
\text { resources are } \\
\text { focused on } \\
\text { radically new } \\
\text { knowledge or on } \\
\text { incrementally } \\
\text { enhancing the } \\
\text { existing } \\
\text { knowledge base }\end{array}$ & $\begin{array}{l}\text { The relationship between } \\
\text { exploration and } \\
\text { performance is linear and } \\
\text { positive, while the } \\
\text { relationship between } \\
\text { exploitation and } \\
\text { performance is concave.. }\end{array}$ \\
\hline $\begin{array}{l}\text { Jansen, Van } \\
\text { Den Bosch, } \\
\text { and Volberda- } \\
2006 \text { (MS) }\end{array}$ & \begin{tabular}{|l} 
Do units adopt \\
different \\
coordination \\
mechanisms to \\
develop \\
exploratory and \\
exploitative \\
innovation. \\
And under what \\
condition the \\
innovation \\
process impact \\
financial \\
performance? \\
\end{tabular} & $\begin{array}{l}\text { Contingent } \\
\text { Theory, } \\
\text { Organization } \\
\text { Theory }\end{array}$ & & $\begin{array}{l}\text { Survey-based } \\
\text { Quantitative } \\
\text { Study, } \\
\text { Hierarchical } \\
\text { regression } \\
\text { analyses }\end{array}$ & Exploitation & $\begin{array}{l}\text { Exploration } \\
\text { Innovation }\end{array}$ & & \begin{tabular}{|l|} 
Antecedents: \\
firms investment \\
on developing \\
coordination \\
mechanism
\end{tabular} & $\begin{array}{l}\text { Exploratory } \\
\text { factor } \\
\text { analysis } \\
\text { (dependent } \\
\text { variables, } \\
\text { independent } \\
\text { variables, and } \\
\text { moderating } \\
\text { variables) } \\
\text { clearly } \\
\text { replicated the } \\
\text { intended seven- } \\
\text { factor structure. }\end{array}$ & $\begin{array}{l}\text { Centralization negatively } \\
\text { affects exploratory } \\
\text { innovation, whereas } \\
\text { formalization positively } \\
\text { influences exploitative } \\
\text { innovation. Interestingly, } \\
\text { connectedness within } \\
\text { units appears to be an } \\
\text { important antecedent of } \\
\text { both exploratory and } \\
\text { exploitative innovation. }\end{array}$ \\
\hline $\begin{array}{l}\text { Lavie \& } \\
\text { Rosenkopf, } \\
\text { _2006 (AMJ) }\end{array}$ & $\begin{array}{l}\text { Do firms balance } \\
\text { exploration and } \\
\text { exploitation in } \\
\text { their alliance } \\
\text { formation } \\
\text { decisions and, if } \\
\text { so, why and how? }\end{array}$ & $\begin{array}{l}\text { Absorptive } \\
\text { Capacity and } \\
\text { Organization } \\
\text { Inertia }\end{array}$ & $\begin{array}{l}\text { Alliances } \\
\text { formed by U.S. } \\
\text { software firms. } \\
19,928 \\
\text { alliances } \\
\text { involving } \\
8,469 \text { unique } \\
\text { partners }\end{array}$ & $\begin{array}{l}\text { Archival } \\
\text { Data with } \\
\text { GLS }\end{array}$ & Exploitation & Exploration & $\begin{array}{l}\text { Balance of } \\
\text { exploitation } \\
\text { and } \\
\text { exploration }\end{array}$ & $\begin{array}{l}\text { Outcomes: } \\
\text { Alliances } \\
\text { Formation }\end{array}$ & $\begin{array}{l}\text { Function } \\
\text { Exploration: } \\
\text { R\&D knowledge } \\
\text { generation } \\
\text { Exploration: No } \\
\text { previous } \\
\text { Alliance } \\
\text { experience } \\
\text { Attribute } \\
\text { Exploration: }\end{array}$ & $\begin{array}{l}\text { Firms balance } \\
\text { exploration and } \\
\text { exploitation } \\
\text { across domains, as } \\
\text { indicated by the high level } \\
\text { of structure exploration } \\
\text { versus the low level of } \\
\text { attribute exploration. } \\
\text { Finally, firms balance } \\
\text { exploration } \\
\text { and exploitation over } \\
\text { time.. }\end{array}$ \\
\hline $\begin{array}{l}\text { Fabrizo and } \\
\text { Giacomo_2006 } \\
\text { (AMJ) }\end{array}$ & $\begin{array}{l}\text { Does } \\
\text { heterogeneity of } \\
\text { team members } \\
\text { also affect the } \\
\text { exploration versus } \\
\text { exploitation trade- } \\
\end{array}$ & & $\begin{array}{l}6,446 \text { motion } \\
\text { pictures } \\
\text { produced by } \\
\text { the Hollywood } \\
\text { film industry( } \\
1929-58) \\
\end{array}$ & $\begin{array}{l}\text { Regression } \\
\text { Archival } \\
\text { Data }\end{array}$ & Exploitation & Exploration & Tradeoff & $\begin{array}{l}\text { Antecedents: } \\
\text { organization } \\
\text { structure }\end{array}$ & $\begin{array}{l}\text { Exploration: } 1) \\
\text { the presence of } \\
\text { newcomers } \\
\text { and (2) new } \\
\text { combinations of } \\
\text { team members. }\end{array}$ & $\begin{array}{l}\text { High- and low-status } \\
\text { team members and one- } \\
\text { and three-layer } \\
\text { organizational structures } \\
\text { were expected to be } \\
\text { positively related to }\end{array}$ \\
\hline
\end{tabular}




\begin{tabular}{|c|c|c|c|c|c|c|c|c|c|}
\hline & $\begin{array}{l}\text { off at the } \\
\text { team level and } \\
\text { hence informs } \\
\text { how teams should } \\
\text { best be composed }\end{array}$ & & & & & & & & $\begin{array}{l}\text { exploration, and middle- } \\
\text { status team members and } \\
\text { two-layer } \\
\text { structures were expected } \\
\text { to be negatively related to } \\
\text { it. }\end{array}$ \\
\hline $\begin{array}{l}\text { Beckman } \\
\text { _2006 ( AMJ) }\end{array}$ & $\begin{array}{l}\text { Strategic choices } \\
\text { are driven by } \\
\text { executives' past } \\
\text { experiences. }\end{array}$ & TMT, Learning & $\begin{array}{l}\text { a longitudinal } \\
\text { study of more } \\
\text { than } 170 \\
\text { young high- } \\
\text { technology } \\
\text { firms in } \\
\text { California's } \\
\text { Silicon Valley }\end{array}$ & $\begin{array}{l}\text { Maximum- } \\
\text { likelihood } \\
\text { logistic } \\
\text { regression }\end{array}$ & $\begin{array}{l}\text { Exploitation } \\
\text { Strategy }\end{array}$ & $\begin{array}{l}\text { Exploration } \\
\text { Strategy }\end{array}$ & $\begin{array}{l}\text { Antecedents: } \\
\text { mindset }\end{array}$ & $\begin{array}{l}\text { Exploration: } \\
\text { firm pursued an } \\
\text { exploration } \\
\text { strategy and } \\
\text { changed initial } \\
\text { ideas } \\
\text { Exploitation: } \\
\text { examine time to } \\
\text { first product } \\
\text { (rapid product } \\
\text { shipment is } \\
\text { consistent with } \\
\text { exploitation). }\end{array}$ & $\begin{array}{l}\text { Founding team } \\
\text { prior company affiliations } \\
\text { predict whether a firm } \\
\text { pursues exploratory and } \\
\text { exploitative behavior, and } \\
\text { they also suggest that } \\
\text { firms whose founding } \\
\text { teams have both types of } \\
\text { affiliations are more likely } \\
\text { to grow over time. }\end{array}$ \\
\hline $\begin{array}{l}\text { Auh \&Menguc } \\
\text { _2006 (JBR) }\end{array}$ & $\begin{array}{l}\text { What is the } \\
\text { moderating role of } \\
\text { competitive } \\
\text { intensity on the } \\
\text { relative } \\
\text { effectiveness of } \\
\text { exploration and } \\
\text { exploitation on } \\
\text { firm performance } \\
\text { for prospectors } \\
\text { and defenders. }\end{array}$ & \begin{tabular}{|l|} 
Resource \\
Based View.
\end{tabular} & $\begin{array}{l}260 \text { usable } \\
\text { questionnaires }\end{array}$ & $\begin{array}{l}\text { Survey Based } \\
\text { hierarchical } \\
\text { moderated } \\
\text { regression } \\
\text { analysis }\end{array}$ & $\begin{array}{l}\text { Exploitation } \\
\text { Capabilities }\end{array}$ & $\begin{array}{l}\text { Exploration } \\
\text { Capabilities }\end{array}$ & $\begin{array}{l}\text { Contingent } \\
\text { Factors: } \\
\text { competitive } \\
\text { intensity } \\
\text { Outcomes: } \\
\text { performance }\end{array}$ & $\begin{array}{l}\text { Categories to } \\
\text { measure } \\
\text { exploration such } \\
\text { as research and } \\
\text { development } \\
\text { expenditures for } \\
\text { and exploitation } \\
\text { such as } \\
\text { Modernization } \\
\text { and automation } \\
\text { of production } \\
\text { processes. }\end{array}$ & $\begin{array}{l}\text { For defenders, exploration } \\
\text { will be positively related } \\
\text { to effective firm } \\
\text { performance while } \\
\text { exploitation will be } \\
\text { negatively related to } \\
\text { efficient firm performance } \\
\text { as competitive intensity } \\
\text { increases. for prospectors, } \\
\text { exploration will be } \\
\text { negatively related to } \\
\text { effective firm } \\
\text { performance, whereas } \\
\text { exploitation will be } \\
\text { positively associated with } \\
\text { efficient firm performance } \\
\text { as competition intensifies }\end{array}$ \\
\hline $\begin{array}{l}\text { Rothaermel, } \\
\text { and Deeds } \\
\text { _2004 (SMJ) }\end{array}$ & $\begin{array}{l}\text { Exploration- } \\
\text { exploitation } \\
\text { framework to a } \\
\text { technology } \\
\text { venture's strategic } \\
\text { alliances is used } \\
\text { and the causal } \\
\text { relationship } \\
\text { between the } \\
\text { venture's alliances } \\
\text { and its new } \\
\text { product } \\
\text { development } \\
\text { depends on the } \\
\text { type of the } \\
\text { alliance }\end{array}$ & $\begin{array}{l}\text { Organization } \\
\text { Learning }\end{array}$ & $\begin{array}{l}\text { Sample of } 325 \\
\text { biotechnology } \\
\text { firms that } \\
\text { entered } 2565 \\
\text { alliances over } \\
\text { a } 25 \text {-year } \\
\text { period }\end{array}$ & $\begin{array}{l}\text { Archival } \\
\text { Data-> } \\
\text { Negative } \\
\text { Binomial and } \\
\text { Poisson } \\
\text { model }\end{array}$ & $\begin{array}{l}\text { Exploitation: } \\
\text { alliances that } \\
\text { focus on the } \\
\text { upstream } \\
\text { activities of } \\
\text { the value } \\
\text { chain }\end{array}$ & $\begin{array}{l}\text { Exploration; its } \\
\text { alliances } \\
\text { that focus on the } \\
\text { downstream } \\
\text { activities of the } \\
\text { value } \\
\text { chain }\end{array}$ & $\begin{array}{l}\text { Outcomes: new } \\
\text { product } \\
\text { development } \\
\text { Antecedents: } \\
\text { external } \\
\text { relationship }\end{array}$ & $\begin{array}{l}\text { Exploration } \\
\text { alliances is a } \\
\text { count variable of } \\
\text { its activities } \\
\text { exploitation } \\
\text { alliances is a } \\
\text { count variable of } \\
\text { the activities }\end{array}$ & $\begin{array}{l}\text { On the average, } \\
\text { new technology ventures } \\
\text { that use an exploration- } \\
\text { exploitation strategy in } \\
\text { their product development } \\
\text { efforts tend to have more } \\
\text { products in development } \\
\text { and on the market. And } \\
\text { this product development } \\
\text { path is moderated } \\
\text { negatively by firm size }\end{array}$ \\
\hline
\end{tabular}




\begin{tabular}{|c|c|c|c|c|c|c|c|c|c|c|}
\hline $\begin{array}{l}\text { He and Wong } \\
2004 \text { ( OS) }\end{array}$ & $\begin{array}{l}\text { How exploitation } \\
\text { and exploration } \\
\text { can jointly impact } \\
\text { firms' } \\
\text { performance, } \\
\text { especially in } \\
\text { technology } \\
\text { innovation } \\
\text { context. }\end{array}$ & $\begin{array}{l}\text { Organization } \\
\text { Learning }\end{array}$ & $\begin{array}{l}\text { Manufacturing } \\
\text { firms } \\
\text { in Singapore } \\
\text { and the State } \\
\text { of Penang in } \\
\text { Malaysia } \\
\text { during } \\
\text { 1999-2000 }\end{array}$ & $\begin{array}{l}\text { Hierarchical } \\
\text { Linear } \\
\text { Regression } \\
\text { and Path } \\
\text { Analysis }\end{array}$ & & & $\begin{array}{l}\text { Balance of } \\
\text { exploitation } \\
\text { and } \\
\text { exploration } \\
\text { of technology }\end{array}$ & $\begin{array}{l}\text { Outcomes: sales } \\
\text { growth }\end{array}$ & \begin{tabular}{|l} 
Eight Likert- \\
scale items to \\
measure how \\
firms \\
divide attention \\
and resources \\
between \\
innovation \\
activities \\
with explorative \\
versus \\
exploitative \\
objectives
\end{tabular} & $\begin{array}{l}\text { (a) the interaction } \\
\text { between explorative and } \\
\text { exploitative innovation } \\
\text { strategies is positively } \\
\text { related to } \\
\text { sales growth rate, and (b) } \\
\text { the relative imbalance } \\
\text { between } \\
\text { explorative and } \\
\text { exploitative innovation } \\
\text { strategies is negatively } \\
\text { related to sales growth } \\
\text { rate. }\end{array}$ \\
\hline $\begin{array}{l}\text { Holmqvist } \\
\text { _2004 (OS) }\end{array}$ & $\begin{array}{l}\text { This article } \\
\text { examines how } \\
\text { exploitation and } \\
\text { exploration at } \\
\text { intra and inter- } \\
\text { organization } \\
\text { settings are } \\
\text { interrelated. }\end{array}$ & $\begin{array}{l}\text { Organization } \\
\text { Learning }\end{array}$ & $\begin{array}{l}\text { Scandinavian } \\
\text { software } \\
\text { producer } \\
\text { Scandinavian } \\
\text { PC Systems } \\
(1997-1999)\end{array}$ & Case Studies & & & $\begin{array}{l}\text { Interaction of } \\
\text { exploitation } \\
\text { and } \\
\text { exploration }\end{array}$ & $\begin{array}{l}\text { Antecedents: } \\
\text { firms capability } \\
\text { development }\end{array}$ & $\begin{array}{l}\text { Exploitation is } \\
\text { about creating } \\
\text { reliability in } \\
\text { experience, and } \\
\text { thrives on } \\
\text { productivity and } \\
\text { refinement. } \\
\text { Exploration is } \\
\text { concerned with } \\
\text { creating variety } \\
\text { in experience, } \\
\text { and thrives on } \\
\text { experimentation } \\
\text { and free } \\
\text { association. }\end{array}$ & $\begin{array}{l}\text { Conceptual model about } \\
\text { how exploitation } \\
\text { is interlaced with } \\
\text { exploration within and } \\
\text { between } \\
\text { organizations }\end{array}$ \\
\hline $\begin{array}{l}\text { Lee, Lee and } \\
\text { Lee I_2003 } \\
\text { (MS) }\end{array}$ & $\begin{array}{l}\text { This study } \\
\text { examines the } \\
\text { conditions under } \\
\text { which exploration } \\
\text { of a new, } \\
\text { incompatible } \\
\text { technology is } \\
\text { conducive to firm } \\
\text { growth in the } \\
\text { presence of } \\
\text { network } \\
\text { externalities. }\end{array}$ & $\begin{array}{l}\text { Technology } \\
\text { Evolution and } \\
\text { Organizational } \\
\text { Learning }\end{array}$ & $\begin{array}{l}\text { Divergent } \\
\text { evolutions of } \\
\text { the PC and the } \\
\text { workstation } \\
\text { markets in } \\
\text { response to a } \\
\text { new } \\
\text { technology: } \\
\text { reduced } \\
\text { instruction set } \\
\text { computing } \\
\text { (RISC). }\end{array}$ & Simulation & $\begin{array}{l}\text { Exploitation } \\
\text { capabilities } \\
\text { on } \\
\text { technology }\end{array}$ & $\begin{array}{l}\text { Exploration } \\
\text { capabilities }\end{array}$ & & $\begin{array}{l}\text { Contingent } \\
\text { factors: } \\
\text { technology } \\
\text { Outcome: growth }\end{array}$ & $\begin{array}{l}\text { Exploration: } \\
\text { introducing a } \\
\text { new technology } \\
\text { Exploitation: }\end{array}$ & $\begin{array}{l}\text { Exploration of a new, } \\
\text { incompatible technology } \\
\text { is more likely to increase } \\
\text { the chance of firm growth } \\
\text { when there are a } \\
\text { substantial number of } \\
\text { power users or when a } \\
\text { new technology is } \\
\text { introduced before an } \\
\text { established technology } \\
\text { takes off. }\end{array}$ \\
\hline $\begin{array}{l}\text { Benner MJ, } \\
\text { Tushman } \\
\text { ML_2003 } \\
\text { (AMR) }\end{array}$ & $\begin{array}{l}\text { how process } \\
\text { management } \\
\text { activities affect } \\
\text { both technological } \\
\text { innovation and } \\
\text { organizational } \\
\text { adaptation }\end{array}$ & $\begin{array}{l}\text { Innovation, } \\
\text { Resources } \\
\text { Dependency, } \\
\text { dynamic } \\
\text { capabilities }\end{array}$ & & $\begin{array}{l}\text { Conceptual } \\
\text { Model }\end{array}$ & $\begin{array}{l}\text { Process } \\
\text { Management }\end{array}$ & $\begin{array}{l}\text { Exploitation: } \\
\text { Incremental } \\
\text { technology, } \\
\text { innovation for } \\
\text { existing } \\
\text { customer and } \\
\text { capabilities on } \\
\text { existing } \\
\text { knowledge }\end{array}$ & $\begin{array}{l}\text { Exploration: } \\
\text { Radical } \\
\text { Technology, } \\
\text { innovation } \\
\text { for new } \\
\text { customers } \\
\text { and new } \\
\text { knowledge }\end{array}$ & $\begin{array}{l}\text { Antecedents: } \\
\text { process } \\
\text { management as } \\
\text { capabilities }\end{array}$ & & $\begin{array}{l}\text { Process management is } \\
\text { associated with } \\
\text { incremental innovation } \\
\text { and existing customer } \\
\text { sets, but negatively } \\
\text { associated with } \\
\text { architectural innovation, } \\
\text { radical innovation and } \\
\text { new customer base. } \\
\text { Organization design, } \\
\text { technology cycle, stability } \\
\text { of environment }\end{array}$ \\
\hline
\end{tabular}




\begin{tabular}{|c|c|c|c|c|c|c|c|c|c|}
\hline $\begin{array}{l}\text { Benner \& } \\
\text { Tushman_ } \\
2002 \\
\text { (ASQ) }\end{array}$ & $\begin{array}{l}\text { Process } \\
\text { Management } \\
\text { reduce variance in } \\
\text { organizational } \\
\text { routines and } \\
\text { influence the } \\
\text { selection of } \\
\text { innovations, they } \\
\text { enhance } \\
\text { incremental } \\
\text { innovation at the } \\
\text { expense of } \\
\text { exploratory } \\
\text { innovation. }\end{array}$ & $\begin{array}{l}\text { Organization } \\
\text { Learning and } \\
\text { Evolution }\end{array}$ & $\begin{array}{l}\text { 20-year } \\
\text { longitudinal } \\
\text { study of } \\
\text { patenting } \\
\text { activity and } \\
\text { ISO } 9000 \\
\text { quality } \\
\text { program } \\
\text { certifications } \\
\text { in the paint } \\
\text { and } \\
\text { photography } \\
\text { industries. }\end{array}$ & $\begin{array}{l}\text { Negative } \\
\text { binomial } \\
\text { models and } \\
\text { Time-Series } \\
\text { OLS } \\
\text { regression }\end{array}$ & Innovation & $\begin{array}{l}\text { Patent } \\
\text { Exploitation: } \\
\text { patents cited by } \\
\text { the firm in an } \\
\text { earlier } \\
\text { innovation effort } \\
\text { and/or self- } \\
\text { citations }\end{array}$ & $\begin{array}{l}\text { Patent } \\
\text { Exploration: } \\
\text { the most } \\
\text { exploratory } \\
\text { patent } \\
\text { category } \\
\text { comprises } \\
\text { patents that } \\
\text { depart } \\
\text { entirely from } \\
\text { prior firm } \\
\text { knowledge. } \\
10 \text { percent, } \\
20 \text { percent, } \\
\text { and } 40 \\
\text { percent levels }\end{array}$ & $\begin{array}{l}\text { Antecedents: } \\
\text { process } \\
\text { management as } \\
\text { capabilities } \\
\text { Outcomes: } \\
\text { innovation }\end{array}$ & $\begin{array}{l}\text { Process Management } \\
\text { practices shift the balance } \\
\text { of exploitation and } \\
\text { exploration by focusing } \\
\text { on efficiency, possibly at } \\
\text { the expense of long-term } \\
\text { adaptation. }\end{array}$ \\
\hline $\begin{array}{l}\text { Danneels } \\
\text { _2002 (SMJ) }\end{array}$ & $\begin{array}{l}\text { How do product } \\
\text { innovations } \\
\text { contribute to } \\
\text { firm renewal. } \\
\text { Product } \\
\text { innovation } \\
\text { drives firms' } \\
\text { renewal } \\
\text { through } \\
\text { exploitation and } \\
\text { exploration? }\end{array}$ & $\begin{array}{l}\text { Product } \\
\text { innovation, } \\
\text { Competency, } \\
\text { Organization } \\
\text { Learning }\end{array}$ & $\begin{array}{l}\text { Five high } \\
\text { technology } \\
\text { firms. } 34 \\
\text { interviews }\end{array}$ & $\begin{array}{l}\text { Case } \\
\text { Studies }\end{array}$ & $\begin{array}{l}\text { New } \\
\text { Products }\end{array}$ & $\begin{array}{l}\text { Exploitation } \\
\text { (developing a } \\
\text { product that } \\
\text { draws on } \\
\text { existing } \\
\text { resources) }\end{array}$ & $\begin{array}{l}\text { Exploration } \\
\text { (developing } \\
\text { products } \\
\text { that } \\
\text { require new } \\
\text { resources) }\end{array}$ & $\begin{array}{l}\text { Outcomes: } \\
\text { product } \\
\text { innovation }\end{array}$ & $\begin{array}{l}\text { New product } \\
\text { innovation is a process } \\
\text { built on both } \\
\text { technology and } \\
\text { customer competences. } \\
\text { Those processes are } \\
\text { used to understand } \\
\text { how exploitation and } \\
\text { exploration can serve } \\
\text { to gain dynamic } \\
\text { capabilities and } \\
\text { provide path- } \\
\text { dependency view. }\end{array}$ \\
\hline
\end{tabular}




\section{Appendix C Literature review on international new ventures (Empirical Evidence)}

\begin{tabular}{|c|c|c|c|c|c|c|}
\hline Study & $\begin{array}{c}\text { Research Question } \\
\text { (exploitation, exploration, } \\
\text { ambidexterity) }\end{array}$ & Related Lit & Research Setting & Methodology & $\begin{array}{l}\text { Multi-level, } \\
\text { Country Set }\end{array}$ & Results \\
\hline $\begin{array}{l}\text { Musteen, Francis \& } \\
\text { Datta_2010(JWB) }\end{array}$ & $\begin{array}{l}\text { How network (structural, } \\
\text { cognitive and relational) } \\
\text { impacts SME's } \\
\text { internationalization speed and } \\
\text { performance? }\end{array}$ & $\begin{array}{l}\text { Social Capital, } \\
\text { International } \\
\text { Entrepreneur }\end{array}$ & $\begin{array}{l}155 \text { Czech SMEs } \\
\text { covering a broad } \\
\text { range of } \\
\text { manufacturing } \\
\text { industries }\end{array}$ & $\begin{array}{l}\text { Survey-Based } \\
\text { Quantitative }\end{array}$ & $\begin{array}{l}\text { Founding Team } \\
\text { CEO ties and } \\
\text { firm outcome } \\
\text { Czech SMEs }\end{array}$ & $\begin{array}{l}\text { Firms sharing a common language with their } \\
\text { international ties are able to internationalize faster than } \\
\text { firms that do not share a common language. } \\
\text { Geographically diverse networks contribute to superior } \\
\text { performance. Extensive reliance on personal contacts } \\
\text { hinders the performance of the first international venture }\end{array}$ \\
\hline $\begin{array}{l}\text { Manolova Manev } \\
\text { and Gyoshev_2010 } \\
\text { (JWB) }\end{array}$ & $\begin{array}{l}\text { How personal and inter-firm } \\
\text { ties impact new ventures } \\
\text { internationalization in } \\
\text { emerging countries? }\end{array}$ & $\begin{array}{l}\text { Social network, } \\
\text { International } \\
\text { entrepreneur }\end{array}$ & $\begin{array}{l}\text { Entrepreneurial } \\
\text { ventures }(n=623) \text { in } \\
\text { Bulgaria }\end{array}$ & $\begin{array}{l}\text { Survey-Based } \\
\text { Quantitative }\end{array}$ & Bulgaria & $\begin{array}{l}\text { Domestic personal networks have a positive effect on } \\
\text { internationalization. Firm age negatively moderates the } \\
\text { effect of inter-firm networks }\end{array}$ \\
\hline $\begin{array}{l}\text { Martin-Tapia, } \\
\text { Aragon-Correa , \& } \\
\text { Rueda-Manzanares } \\
\text { 2010(JWB) }\end{array}$ & $\begin{array}{l}\text { Do strategies for environmental } \\
\text { protection can help small and } \\
\text { medium enterprises (SMEs) as } \\
\text { they internationalize their } \\
\text { activities through exports? }\end{array}$ & & $\begin{array}{l}123 \text { general managers } \\
\text { of exporting SMEs } \\
\text { from the Spanish } \\
\text { food industry }\end{array}$ & $\begin{array}{l}\text { Survey-Based } \\
\text { Quantitative }\end{array}$ & Spain & $\begin{array}{l}\text { Relationship between advanced environmental strategies } \\
\text { and export intensity for the sampled firms. However, the } \\
\text { size of firm plays a role in this relationship, as the } \\
\text { relationship between advanced environmental strategies } \\
\text { and exports is stronger with an increase in the size of the } \\
\text { SMEs }\end{array}$ \\
\hline $\begin{array}{l}\text { Zhou, Barnes \& Lu } \\
\text { _2010 (JIBS) }\end{array}$ & $\begin{array}{l}\text { How young international new } \\
\text { ventures acquire learning } \\
\text { advantages and avoid the } \\
\text { liabilities of newness and } \\
\text { foreignness? How young } \\
\text { international new ventures } \\
\text { leverage the entrepreneurial } \\
\text { dynamics of learning? }\end{array}$ & $\begin{array}{l}\text { Organizational Learning } \\
\text { and Newness }\end{array}$ & $\begin{array}{l}436 \text { young INVs from } \\
\text { China }\end{array}$ & $\begin{array}{l}\text { Survey-Based } \\
\text { Quantitative }\end{array}$ & China & $\begin{array}{l}\text { The mediating effect of capability upgrading, particularly } \\
\text { among relatively larger new ventures and those operating } \\
\text { with cost/price advantages in the international } \\
\text { marketplace }\end{array}$ \\
\hline $\begin{array}{l}\text { Camison \&Villar- } \\
\text { Lopez_2010 } \\
\text { (JSBM) }\end{array}$ & $\begin{array}{l}\text { What is the relationship } \\
\text { between the international } \\
\text { experience of small and } \\
\text { medium-sized enterprises } \\
\text { (SMEs) and their economic } \\
\text { performance using intangible } \\
\text { and financial asset stock, } \\
\text { competitive strategy, and } \\
\text { international intensity as } \\
\text { mediating factors }\end{array}$ & RBV & 394 Spanish SMEs & $\begin{array}{l}\text { Survey-Based } \\
\text { Quantitative }\end{array}$ & Spain & $\begin{array}{l}\text { Superior economic performance is only achieved by } \\
\text { SMEs that can turn the knowledge they gain from } \\
\text { international experience into a large endowment of } \\
\text { internationally exploitable intangible assets (irrespective } \\
\text { of the fact that these assets form the basis for } \\
\text { strengthening international intensity) and into a } \\
\text { differentiation competitive strategy }\end{array}$ \\
\hline $\begin{array}{l}\text { Singh, Gaur, and } \\
\text { Schmid_2010 } \\
\text { (MIR) }\end{array}$ & $\begin{array}{l}\text { How the product } \\
\text { diversification (PD) and } \\
\text { geographic diversification } \\
\text { (GD) individually and jointly } \\
\text { affect the performance of } \\
\text { SMEs }\end{array}$ & $\begin{array}{l}\text { Diversification, Upper } \\
\text { Echelon }\end{array}$ & 565 German SMEs & $\begin{array}{l}\text { Survey-Based } \\
\text { Quantitative }\end{array}$ & Germany & $\begin{array}{l}\text { Both PD and GD have an inverted U shaped relationship } \\
\text { with the SME performance. PD and GD interact } \\
\text { positively to enhance each other's value in affecting firm } \\
\text { performance. TMT experience also enhances the value of } \\
\text { PD and GD for firm performance }\end{array}$ \\
\hline
\end{tabular}




\begin{tabular}{|c|c|c|c|c|c|c|}
\hline $\begin{array}{l}\text { Fernhaber \&Li } \\
\text { _2010 (ET\&P) }\end{array}$ & $\begin{array}{l}\text { What is the impact of inter- } \\
\text { organizational imitation on new } \\
\text { venture international entry and } \\
\text { subsequent performance? }\end{array}$ & $\begin{array}{l}\text { Neoinstitutional } \\
\text { Theories and } \\
\text { Organization Learning }\end{array}$ & $\begin{array}{l}150 \text { U.S.-based } \\
\text { publicly held new } \\
\text { ventures }\end{array}$ & Archival Quantitative & US & $\begin{array}{l}\text { New venture international entry is in part an imitative } \\
\text { response to the internationalization of other firms in the } \\
\text { venture's home country industry and/or subsets of firms } \\
\text { with certain traits or outcomes. Inter-organizational } \\
\text { imitation moderates the relationship between new } \\
\text { venture international entry and profitability, but not the } \\
\text { relationship between new venture international entry and } \\
\text { sales growth }\end{array}$ \\
\hline $\begin{array}{l}\text { Lopez, Kundu \& } \\
\text { Ciravegna_2009 } \\
\text { (JIBS) }\end{array}$ & Born global or born regional? & & $\begin{array}{l}40 \text { Costa Rican } \\
\text { software companies }\end{array}$ & $\begin{array}{l}\text { Survey-Based } \\
\text { Quantitative }\end{array}$ & Costa Rica & $\begin{array}{l}\text { Most companies followed a gradual approach to } \\
\text { internationalization, and they did not export immediately } \\
\text { upon birth. A careful analysis of firms that exported soon } \\
\text { after they were born reveals that most firms are actually } \\
\text { "born regional." }\end{array}$ \\
\hline $\begin{array}{l}\text { Brouthers, Nakos, } \\
\text { Hadjimarcou, et } \\
\text { al._2009(JIM) }\end{array}$ & $\begin{array}{l}\text { What key factors result in } \\
\text { superior export performance } \\
\text { for small firms from small } \\
\text { countries? }\end{array}$ & $\begin{array}{l}\text { internationalization } \\
\text { process model and } \\
\text { organizational learning } \\
\text { theory }\end{array}$ & $\begin{array}{l}119 \text { from Greek } \\
\text { companies \& } 83 \text { from } \\
\text { Caribbean companies }\end{array}$ & $\begin{array}{l}\text { Survey-Based } \\
\text { Quantitative }\end{array}$ & $\begin{array}{l}\text { Greece and } \\
\text { Caribbean } \\
\text { countries }\end{array}$ & $\begin{array}{l}\text { Emphasizing international sales while restricting exports } \\
\text { to a few foreign markets results in superior perceived } \\
\text { export performance for the sample of small firms from } \\
\text { Greece and Caribbean countries }\end{array}$ \\
\hline $\begin{array}{l}\text { Filatotchev , Liu, } \\
\text { Buck T, et } \\
\text { al._2009(JIBS) }\end{array}$ & $\begin{array}{l}\text { What are the factors affecting } \\
\text { the export orientation and } \\
\text { export performance of high- } \\
\text { technology Small and medium } \\
\text { enterprises (SMEs) in an } \\
\text { emerging economy? }\end{array}$ & $\begin{array}{l}\mathrm{KBV} \text { and } \\
\text { Internationalization }\end{array}$ & $\begin{array}{l}711 \text { SMEs from } \\
\text { Zhongguancun } \\
\text { Science Park in China }\end{array}$ & $\begin{array}{l}\text { Survey-Based } \\
\text { Quantitative }\end{array}$ & China & $\begin{array}{l}\text { Export orientation and performance depend not only on } \\
\text { the development of capabilities through R\&D and } \\
\text { technology transfer, but also on entrepreneurial } \\
\text { characteristics, such as the founder's international } \\
\text { background and global networks }\end{array}$ \\
\hline $\begin{array}{l}\text { Al-Laham, } \\
\text { \&Souitaris_2008 } \\
\text { (JBV) }\end{array}$ & $\begin{array}{l}\text { Does inter-organizational } \\
\text { factors influence German } \\
\text { biotech firms' propensity to } \\
\text { internationalize by forming } \\
\text { international research alliances }\end{array}$ & $\begin{array}{l}\text { Network, } \\
\text { Internationalization }\end{array}$ & $\begin{array}{l}\text { the complete German } \\
\text { biotech population } \\
\text { for the years 1995- } \\
2004\end{array}$ & $\begin{array}{l}\text { Survey-Based } \\
\text { Quantitative }\end{array}$ & Germany & $\begin{array}{l}\text { Location in a local cluster already dense with } \\
\text { international linkages, the building of research alliances } \\
\text { with local research institutes as well as national partners } \\
\text { and central position in the national research network } \\
\text { increase the probability of forming international research } \\
\text { alliances }\end{array}$ \\
\hline $\begin{array}{l}\text { Nordman \& Melen } \\
\text { _2008 (JWB) }\end{array}$ & $\begin{array}{l}\text { how different kinds of } \\
\text { knowledge of founders and } \\
\text { managers at Born Globals are } \\
\text { related to the firms' discovery } \\
\text { and exploitation of foreign } \\
\text { market opportunities }\end{array}$ & & $\begin{array}{l}\text { eight biotech Born } \\
\text { Globals }\end{array}$ & $\begin{array}{l}\text { Case Based } \\
\text { Qualitative }\end{array}$ & & $\begin{array}{l}\text { The founders' and managers' different combinations of } \\
\text { technological and international knowledge impact the } \\
\text { firms' proactive or reactive behavior in discovering } \\
\text { foreign market opportunities. }\end{array}$ \\
\hline $\begin{array}{l}\text { Coeurderoy, } \\
\text { Murray_2008 } \\
\text { (JIBS) }\end{array}$ & $\begin{array}{l}\text { What is the effect of the } \\
\text { institutional dimension, } \\
\text { specifically the national } \\
\text { regulatory environment, on the } \\
\text { location choices and the speed } \\
\text { of internationalisation by } \\
\text { British and German NTBFs }\end{array}$ & TCE & $\begin{array}{l}\text { British and German } \\
\text { NTBFs }\end{array}$ & $\begin{array}{l}\text { Survey-Based } \\
\text { Quantitative }\end{array}$ & $\begin{array}{l}\text { British and } \\
\text { Germany }\end{array}$ & $\begin{array}{l}\text { Entrepreneurial young firms choose to enter country } \\
\text { markets offering better regulatory protection for their } \\
\text { intellectual property. This decision is moderated by a } \\
\text { home regulatory regime bias. the speed of } \\
\text { Internationalisation is influenced less by the foreign } \\
\text { regulatory regime and more by industry and firm } \\
\text { characteristics. Managerial experience influences the } \\
\text { location choices of NTBFs facing hazards. }\end{array}$ \\
\hline
\end{tabular}




\begin{tabular}{|c|c|c|c|c|c|c|}
\hline $\begin{array}{l}\text { Fernhaber, Gilbert, } \\
\text { McDougall_2008 } \\
\text { (JIBS) }\end{array}$ & $\begin{array}{l}\text { How geographic location may } \\
\text { be one reason why some } \\
\text { ventures are able to acquire the } \\
\text { resources needed to } \\
\text { internationalize while others } \\
\text { cannot? }\end{array}$ & $\begin{array}{l}\text { Clustering and } \\
\text { Resources Dependency }\end{array}$ & $\begin{array}{l}156 \text { publicly held } \\
\text { new ventures }\end{array}$ & Archival-Quantitative & US & $\begin{array}{l}\text { An inverted U-shaped relationship between the } \\
\text { concentration of industry clustering within a geographic } \\
\text { location and the venture's internationalization. }\end{array}$ \\
\hline $\begin{array}{l}\text { Loane, Bell, } \\
\text { McNaughton_2007 } \\
\text { (JWB) }\end{array}$ & $\begin{array}{l}\text { Top management teams in the } \\
\text { formation and development of } \\
\text { new ventures impact on the } \\
\text { rapid internationalization of } \\
\text { such firms remains relatively } \\
\text { under-researched }\end{array}$ & Internationalization & $\begin{array}{l}\text { cross-national study } \\
\text { conducted in } \\
\text { Australia, Canada, } \\
\text { Ireland and New } \\
\text { Zealand }\end{array}$ & $\begin{array}{l}\text { Survey-Based } \\
\text { Quantitative }\end{array}$ & $\begin{array}{l}\text { Australia, } \\
\text { Canada, } \\
\text { Ireland and } \\
\text { New Zealand }\end{array}$ & $\begin{array}{l}\text { Teams have in creating the core internal capabilities and } \\
\text { leveraging the external resources required for rapid and } \\
\text { dedicated internationalization }\end{array}$ \\
\hline Zhou_2007 (JWB) & $\begin{array}{l}\text { What is the role of foreign } \\
\text { market knowledge between the } \\
\text { process models of } \\
\text { internationalization and the } \\
\text { early internationalization of } \\
\text { born-global firms }\end{array}$ & $\begin{array}{l}\text { KBV and } \\
\text { Internationalization }\end{array}$ & $\begin{array}{l}\text { young international } \\
\text { entrepreneurial firms } \\
\text { in mainland China }\end{array}$ & $\begin{array}{l}\text { Survey-Based } \\
\text { Quantitative }\end{array}$ & China & $\begin{array}{l}\text { mediating mechanism of foreign market knowledge as it } \\
\text { relates to the pace and performance of early } \\
\text { internationalization }\end{array}$ \\
\hline $\begin{array}{l}\text { Gleason \& } \\
\text { Wiggenhorn_2007 } \\
\text { (JWB) }\end{array}$ & $\begin{array}{l}\text { Which characteristics of born } \\
\text { global firms determine their } \\
\text { choice for international entry } \\
\text { mode? }\end{array}$ & Internationalization & $\begin{array}{l}124 \text { newly public } \\
\text { firms in the United } \\
\text { States }\end{array}$ & Archival-Quantitative & US & $\begin{array}{l}\text { Market responds positively to announcements of } \\
\text { international expansions by born global firms, and that } \\
\text { larger, more profitable, and more liquid firms have a } \\
\text { higher propensity to engage in joint ventures rather than } \\
\text { acquisitions. market favors firms that announce joint } \\
\text { ventures, rewarding them with significantly positive } \\
\text { abnormal returns }\end{array}$ \\
\hline $\begin{array}{l}\text { Zhou, Wu, Luo } \\
\text { _2007 (JIBS) }\end{array}$ & $\begin{array}{l}\text { What is the purported } \\
\text { relationship between } \\
\text { internationalization and firm } \\
\text { performance in the context of } \\
\text { born-global small and medium } \\
\text { enterprises (SMEs) }\end{array}$ & Social Network & $\begin{array}{l}\text { SMEs in the largest } \\
\text { emerging economy of } \\
\text { China }\end{array}$ & $\begin{array}{l}\text { Survey-Based } \\
\text { Quantitative }\end{array}$ & China & $\begin{array}{l}\text { Some support for this mediating role of social networks } \\
\text { in the form of guanxi }\end{array}$ \\
\hline $\begin{array}{l}\text { Chung, Chen, and } \\
\text { Hsieh_2007 (JBR) }\end{array}$ & $\begin{array}{l}\text { What are the factors that may } \\
\text { influence the propensity of } \\
\text { startup firms to launch first } \\
\text { geographic expansion? }\end{array}$ & & $\begin{array}{l}147 \text { Taiwanese } \\
\text { Companies }\end{array}$ & $\begin{array}{l}\text { Survey-Based } \\
\text { Quantitative }\end{array}$ & Taiwan & $\begin{array}{l}\text { Firm initial size and late entry have a. positive } \\
\text { relationship with firm propensity to launch first } \\
\text { geographic expansion, and that firm initial size } \\
\text { negatively moderates the relationship between firm late } \\
\text { entry and the likelihood of undertaking geographic } \\
\text { expansion }\end{array}$ \\
\hline $\begin{array}{l}\text { Fernandez and Nieto } \\
\text { _2006 (JIBS) }\end{array}$ & $\begin{array}{l}\text { What is the relationship } \\
\text { between the } \\
\text { internationalization strategies } \\
\text { of SMEs and types of } \\
\text { ownership? }\end{array}$ & Governance & Spanish SMEs & $\begin{array}{l}\text { Survey-Based } \\
\text { Quantitative }\end{array}$ & Spain & $\begin{array}{l}\text { Internationalization is negatively related to family } \\
\text { ownership and positively related to corporate ownership. } \\
\text { Presence of a corporate block holder in family firms } \\
\text { encourages internationalization }\end{array}$ \\
\hline
\end{tabular}




\begin{tabular}{|c|c|c|c|c|c|c|}
\hline $\begin{array}{l}\text { Lu and Beamish } \\
\text { _2006 (JWB) }\end{array}$ & $\begin{array}{l}\text { Partnering strategies in the } \\
\text { formation of IJVs can have } \\
\text { significant effects on the } \\
\text { outcome of SMEs' international } \\
\text { expansion }\end{array}$ & & $\begin{array}{l}1117 \text { international } \\
\text { joint ventures } \\
\text { established in } 43 \\
\text { countries by } 614 \\
\text { Japanese SMEs }\end{array}$ & $\begin{array}{l}\text { Survey-Based } \\
\text { Quantitative }\end{array}$ & Japan & $\begin{array}{l}\text { SMEs' IJVs with local partner(s) may be associated with } \\
\text { decreases in longevity, especially when SMEs acquire } \\
\text { host country knowledge }\end{array}$ \\
\hline $\begin{array}{l}\text { Haahti, Madupu, } \\
\text { Yavas, et al._2005 } \\
\text { (JWB) }\end{array}$ & $\begin{array}{l}\text { What are the relationships } \\
\text { among cooperative strategy, } \\
\text { knowledge intensity and export } \\
\text { perform? }\end{array}$ & & $\begin{array}{l}\text { small and medium } \\
\text { sized enterprises } \\
\text { (SMEs) from Finland } \\
\text { and Norway } \\
\end{array}$ & $\begin{array}{l}\text { Survey-Based } \\
\text { Quantitative }\end{array}$ & $\begin{array}{l}\text { Finland and } \\
\text { Norway }\end{array}$ & $\begin{array}{l}\text { Knowledge intensity mediates the relationship between } \\
\text { cooperative strategy and export performance. Firm size } \\
\text { did not show a direct impact on performance }\end{array}$ \\
\hline $\begin{array}{l}\text { Leiblein and Reuer } \\
\_2004 \text { (JBV) }\end{array}$ & $\begin{array}{l}\text { How technological capabilities } \\
\text { and international collaborative } \\
\text { linkages affect entrepreneurial } \\
\text { firms' abilities to build a } \\
\text { foreign sales base in a highly } \\
\text { competitive global industry }\end{array}$ & Dynamic Capabilities & $\begin{array}{l}\text { North American } \\
\text { semiconductor firms }\end{array}$ & Archival-Quantitative & US & $\begin{array}{l}\text { Both technological capabilities and international } \\
\text { collaboration potentially aid firms' development of } \\
\text { foreign sales }\end{array}$ \\
\hline Qian_2002(JBV) & $\begin{array}{l}\text { Individual and joint effects of } \\
\text { multinationality and product } \\
\text { diversification on profit } \\
\text { performance for a sample of } \\
\text { emerging SMEs. }\end{array}$ & Diversification & 71 emerging SMEs & Archival-Quantitative & US & $\begin{array}{l}\text { A curvilinear relationship between geographic and } \\
\text { product diversification and profit performance }\end{array}$ \\
\hline $\begin{array}{l}\text { Kuemmerle } \\
\_2002(J W B)\end{array}$ & $\begin{array}{l}\text { the scope and sequence of } \\
\text { international activities carried } \\
\text { out by nascent international } \\
\text { ventures }\end{array}$ & $\begin{array}{l}\text { FDI and Knowledge } \\
\text { based-view }\end{array}$ & $\begin{array}{l}6 \text { six international } \\
\text { ventures }\end{array}$ & $\begin{array}{l}\text { Case-based } \\
\text { qualitative }\end{array}$ & US & $\begin{array}{l}\text { International ventures are conceived as 'international' } \\
\text { because cross-border activities increase the chances of } \\
\text { venture survival and growth }\end{array}$ \\
\hline $\begin{array}{l}\text { Lu and Beamish } \\
\text { _2001 (SMJ) }\end{array}$ & $\begin{array}{l}\text { What are the effects of } \\
\text { internationalization, an } \\
\text { entrepreneurial strategy } \\
\text { employed by small and } \\
\text { medium-sized enterprises } \\
\text { (SMEs), on firm performance }\end{array}$ & IB and Entrepreneurship & 164 Japanese SMEs & Archival-Quantitative & Japanese & $\begin{array}{l}\text { Positive impact of inter-nationalization on performance } \\
\text { extends primarily from the extent of a firm's FDI activity. }\end{array}$ \\
\hline $\begin{array}{l}\text { Chen and Martin } \\
\text { 2001(JBV) }\end{array}$ & $\begin{array}{l}\text { How a small firm's foreign } \\
\text { expansion is affected by the } \\
\text { join effects of prior foreign } \\
\text { business involvement and other } \\
\text { factors }\end{array}$ & IB & $\begin{array}{l}49 \text { firms in U.S. } \\
\text { electronic } \\
\text { components industry } \\
\text { Standard Industrial } \\
\text { Classification Index } \\
\text { or SIC-36 from } 1977 \\
\text { to } 1992\end{array}$ & Archival-Quantitative & US & $\begin{array}{l}\text { Encountering performance downturn and market size } \\
\text { decline, small firms with prior foreign business } \\
\text { involvement are more likely to use foreign expansion to } \\
\text { deal with the problems }\end{array}$ \\
\hline $\begin{array}{l}\text { Westhead, Wright, } \\
\text { Ucbasaran } \\
\text { _2001(JBV) }\end{array}$ & $\begin{array}{l}\text { Is a firm still an exporter or a } \\
\text { nonexporter, Are exporting } \\
\text { firms larger in size than } \\
\text { nonexporting firms; is } \\
\text { exporting firms report superior } \\
\text { performance than nonexporting } \\
\text { firms, and whether exporting } \\
\text { firms are more likely to survive } \\
\text { than nonexporting firms? }\end{array}$ & RBV & $\begin{array}{l}621 \text { manufacturing, } \\
\text { construction, and } \\
\text { services businesses } \\
\text { located in twelve } \\
\text { contrasting } \\
\text { environments in } \\
\text { Great Britain }\end{array}$ & $\begin{array}{l}\text { Survey-Based } \\
\text { Quantitative }\end{array}$ & Great Britain & $\begin{array}{l}\text { Previous experience of selling goods or services abroad } \\
\text { is a key influence encouraging firms to export }\end{array}$ \\
\hline
\end{tabular}




\begin{tabular}{|l|l|l|l|l|l|}
\hline $\begin{array}{l}\text { Zahra, Ireland, } \\
\text { Hitt_2000 (AMJ) }\end{array}$ & $\begin{array}{l}\text { How new ventures use the } \\
\text { technological learning gained } \\
\text { through internationalization }\end{array}$ & RBV, learning & 321 US firms & $\begin{array}{l}\text { Survey-Based } \\
\text { Quantitative }\end{array}$ & $\begin{array}{l}\text { Effects of international expansion, as measured by } \\
\text { international diversity and mode of market entry, on a } \\
\text { firm's technological learning and the effects of this } \\
\text { learning on the firm's financial performance }\end{array}$ \\
\hline $\begin{array}{l}\text { Reuber and Fischer } \\
\text {-1997 (JIBS) }\end{array}$ & $\begin{array}{l}\text { Why are some small and } \\
\text { medium-sized enterprises } \\
\text { (SMEs) more successful in } \\
\text { selling outside their domestic } \\
\text { markets than are other SMEs in } \\
\text { the same industry? }\end{array}$ & & $\begin{array}{l}\text { Survey-Based } \\
\text { Quantitative } \\
\text { greater propensity to develop foreign strategic have a } \\
\text { and to delay less in obtaining foreign sales after start-up, } \\
\text { and that these behaviors are associated with a higher } \\
\text { degree of internationalization. }\end{array}$ \\
\hline
\end{tabular}




\section{Appendix D Case study for conceptualization of international ambidexterity}

MNC scholars have called for more and better-guided longitudinal case studies of MNCs (Parkhe, 1993; Werner, 2002). International business studies mostly focus on the complex plurality of the contexts, including institutional, cultural and organizational contexts, brought on by globalization. However, studies on knowledge within MNCs haven't distinguished between "codified knowledge" (mostly used in quantitative methods) and "complex knowledge" (used in qualitative research). Therefore some of the key constructs related to knowledge and technology have been overlooked (Birkinshaw, Brannen and Tung, 2011). In addition, the topics in the international entrepreneurship field provide opportunities for qualitative studies. The internationalization process for new ventures provides a nice study setting for deeper understanding of micro-processes and of collaboration and integrative activities. In 2011, the Journal of International Business Studies published a special issue which called for more qualitative studies in international business (Birkinshaw et al. 2011). It provides me clearer guidelines to conduct my case study.

Case study can be appropriate to understand a social problem. Different from the crosssectional quantitative analysis, longitudinal case studies can provide the opportunity for developing more advanced and complete knowledge about the holistic, dynamic and paradoxical nature of the firms (Eisenhardt, 1989, Numagani, 1998 and Yin, 1994). This approach is interpretative and may help answering questions, such as the "how", "who" and "why" of individual and collective organized action. International new ventures challenge the existing MNC literature by showing a phenomenon of rapid internationalization without abundant resources. This type of qualitative study requires methods which can provide thick descriptions 
of phenomena and stronger conceptualization through new theoretical insights. The international entrepreneurship literature needs to build original theories, and qualitative studies can bring a variety of theoretical lenses to systematically compare the nature of the insights from different sources. In particular, my study is focused on theory building and construct development for further testing, thus an inductive case study is needed. A qualitative study can contribute to the theory testing as well. It may compare the prediction made from the theory and challenge the validity of the constructs built on phenomena of international new ventures. Furthermore, a quantitative study following the qualitative findings is included.

For the purpose of this qualitative study, I considered several criteria in selecting these firms to develop the concept of international exploitation, exploration and ambidexterity. First of all, I selected an industry where technology drives new venture growth, because my focal organizations are those which go through interesting changes faster, rather than in the slower moving population where time results in greater costs. In addition, I selected an industry where internationalization is a common event, thus I can have a variety of internationalization processes among new ventures. Therefore, I selected the information technology (IT) industry for my ideal sample setting. In addition, new ventures from the information technology industry are not necessarily born global and they face challenges to go international, as do new ventures from other industries. However, McDougall and Oviatt (2000) mentioned that new ventures from the IT industry are critical for us to understand how new ventures can learn from internationalization for further growth. Therefore, I selected Information Technology firms from Hoover's Handbook of Emerging Companies (2000). I limited my selection to US firms because they have made the fastest advances in global competition. 
And within the information technology industry, I specifically focused on the dot.com sector for my case studies, as it is one of the most globalized industries, which had a high degree of internationalization, to study the issue of international new venture evolution. During the time between 1994 and 2002, dot.com start-ups intensively solicited and received funding from venture capitalists to pursue high growth. And in the entrepreneurship literature, high growth was considered as a formidable objective for these firms (Shane, 2000), including Yahoo!, Amazon, and Google. Meanwhile, there were also new ventures in this industry who suffered from struggling for survival and a massive number of companies filed for bankruptcy or were acquired, such as 24/7 media and AboveNet Communication. Thus these new ventures provide a broad variation of performance measures.

\section{Qualitative Data collection}

I collected the data for this study primarily from archived documents, including published books such as Hoover's Handbook of Emerging Companies, corporate reports such as SEC filings, newspaper and magazine articles, and other case studies of the four firms. The data were coded according to the content analysis procedures recommended by Yin (1994).

Hoover's Handbook of Emerging Companies is one of America's premier sources of business information on young, growth-oriented enterprises. Since 2000, this handbook has provided information including multiple years of financial information, product information where available, and a long list of company executives. Hoover's selection of firms was based primarily on sales growth and profitability. However, given that my research focus is new ventures, I excluded those firms more than 8 years old by the time they initiated their 
internationalization processes. In addition, I excluded those firms without clear internationalization information; these criteria gave me 14 firms for further evaluation.

My study focuses on selecting four comparable companies (one having international ambidexterity, one having international exploration, and two having international exploitation with different degrees of late exploitation), which issued IPOs before 2000. These firms are aligned with my research questions and are included among the "Highest growing companies" listed in Hoover's Handbook of Emerging Companies: all of them have the objective to expand and accelerate growth in the same industry. I selected all the firms which are aimed at the development of internet-based sales in Hoover's Handbook of Emerging Companies' database. And I focused on those which have several common organizational features, such as age, IPO year, and industry, thus guaranteeing comparability. As validation for this selection, the prospectus for one selected firm reinforces the importance of growth with the following statement: "we have grown, and expect to continue to growth rapidly." Another firm stated that it, "intends to continue building on the capabilities of its network to expand its target market... in multiple dwelling units as well as international opportunities either through joint ventures or by direct entry."

These data only include public firms for information availability reasons. First, I identified internationalization events as the unit of analysis. Second, I coded those events according to the timing of their occurrence (Pre and Post-IPO Internationalization) and also market scope categories (number of countries of operation after IPO). Within each temporal or spatial category, I also recoded the events into sub-categories. Finally, I only used data that were corroborated from multiple sources, such as SEC filings and company websites. Four Case Study 
Abstracts are included in Table below. These abstracts provide the histories of the firms' internationalization processes. The observation information includes the following dimensions of the study: 1) Early Internationalization Time (Before IPO), 2) Early Internationalization Locations (Before IPO), 3) Later Internationalization Scope (After IPO), 4) Later Internationalization Ownership (After IPO), and 5) Firm Financial Performance. The four-case studies were developed to search for patterns within the data, and draw tentative conclusions. I followed the firms from their foundation year to the final year for which data were available. Because my study only focuses on new ventures, the period of time covered is actually between 1995 and 2003. The first step of my data gathering process was to develop a comprehensive collection of publicly accessible sources of evidence. I collected extensive archival data on four companies and most of the data come from the business press and SEC filings. Furthermore, when I conducted my quantitative study, I enlarged my sample size to multiple high technology industries and broadened the IPO years to ten years (1998-2008), thus allowing me to generalize my qualitative findings in different settings. Further, I included industries and IPO year as control variables in my quantitative study. 


\section{Description of four companies in case studies}

\begin{tabular}{|c|c|c|c|c|c|}
\hline & Description & Internationalization & Time & Geographic Scope & Activity \\
\hline $\begin{array}{l}\text { Verticalnet, } \\
\text { Inc }\end{array}$ & $\begin{array}{l}\text { Verticalnet, Inc (International Exploitation) } \\
\text { Located at Horsham PA, Verticalnet, Inc operates more than } \\
55 \text { Web sites focusing on about a dozen industry groups. Verticalnet was } \\
\text { founded in } 1995 \text { and operates through expanding its Web-site portfolio. It } \\
\text { went public at 1999. In 1999, VerticalNet was the largest B-2-B vertical } \\
\text { trade community online. In 2000, they launched VerticalNet Europe for } \\
\text { the European market. } \\
\text { CEO: Mark L. Walse }\end{array}$ & $\begin{array}{l}\text { Exploitation within } 5 \text { years } \\
\text { but after IPO, subsequent international } \\
\text { expansion with location exploitation. }\end{array}$ & $\begin{array}{l}\text { No } \\
\text { Internationalization } \\
\text { before IPO }\end{array}$ & $\begin{array}{l}\text { First FDI to Canada and } \\
\text { Europe, then China }\end{array}$ & $\begin{array}{l}\text { Merger and } \\
\text { Acquisition } \\
\text { with Chinese }\end{array}$ \\
\hline $\begin{array}{l}\text { E*Trade } \\
\text { Group, Inc }\end{array}$ & $\begin{array}{l}\text { E*Trade Group, Inc } \\
\text { Located at Palo Alto, E*Trade, Inc is a California-based } \\
\text { company which has become the \#3 online brokerage. It went public at } \\
\text { 1996, and began internationalization in } 1997 \text { and 1998. By 1999, it's } \\
\text { international sales achieved 111 millions dollars, which accounts for 17\% } \\
\text { of the total revenue of the year. First foreign expansion was in Australia, } \\
\text { Canada, Germany and Isreal. Australian, Canadian, German, Israeli. } \\
\text { CEO: William, A. Porter }\end{array}$ & \begin{tabular}{l}
\multicolumn{1}{c}{ First foreign expansion } \\
after IPO was see text at left. This is a \\
later internationalization with broader \\
scope of subsequent \\
internationalization process.
\end{tabular} & $\begin{array}{l}\text { No } \\
\text { Internationalization } \\
\text { before IPO }\end{array}$ & $\begin{array}{l}\text { apan and subsequent } \\
\text { exploration }\end{array}$ & $\begin{array}{l}\text { Broader scope } \\
\text { of exploration }\end{array}$ \\
\hline Teligent, Inc. & $\begin{array}{l}\text { Teligent, Inc. - Viginia-based Teligent is a competitive local- } \\
\text { exchange carrier and serves up telecommunications services using digital } \\
\text { microwave signals rather than copper wires. It went public in } 1997 \text { and } \\
\text { already launched service in } 10 \text { markets in 1998. It had service in } \\
\text { Argentina, Germany, Hong Kong and France in 2001. However, by } \\
\text { 2002, their operating losses were significant. } \\
\text { CEO: Alex J. Mandl. }\end{array}$ & $\begin{array}{l}\text { This is an international } \\
\text { exploration driven company. }\end{array}$ & $\begin{array}{l}\text { Internationalization } \\
\text { before IPO }\end{array}$ & First FDI to Asia & $\begin{array}{l}\text { Direct Sales to } \\
\text { multiple } \\
\text { countries }\end{array}$ \\
\hline $\begin{array}{c}\text { Actuate } \\
\text { Corporation }\end{array}$ & $\begin{array}{l}\text { Actuate Corporation - (Hoover's Emerging Companies, } \\
\text { Harvard Business Cases) } \\
\text { Actuate Corporation is a California based company which } \\
\text { develops information delivery software that corporations use to create, } \\
\text { publish and distribute documents and complex reports through corporate } \\
\text { networks and the Internet. It was founded in } 1993 \text { and went public in } \\
\text { 1998. At the same time, they bought a number of distributors in France, } \\
\text { Germany and the UK, thus with an early stage for international } \\
\text { exploration. } \\
\text { CEO: Nicolas C. Nierenberg }\end{array}$ & $\begin{array}{l}\text { Early internationalizaiton with } \\
\text { subsequent international exploitation }\end{array}$ & $\begin{array}{l}\text { hinternationalization } \\
\text { before IPO }\end{array}$ & $\begin{array}{l}\text { First FDI to France, } \\
\text { Germany and UK by } \\
\text { acquiring a number of } \\
\text { distributors }\end{array}$ & $\begin{array}{l}\text { Incremental } \\
\text { steps entering } \\
\text { into different } \\
\text { markets }\end{array}$ \\
\hline
\end{tabular}


I used the comparative approach that involves the evaluation of acquired data and theory. I reviewed archival internal strategy documents of the four selected companies to identify international events for content analysis. By integrating the document, I attempted to embed categories of data associated with the case study evidence in theoretical concepts, including international ambidexterity, international exploitation and international exploration. Statements such as, "Our international strategy consists of acquiring or entering into strategic alliances with existing Internet advertising networks in foreign countries" were used to develop the conceptualization of the model. This example refers to the evidence from this study regarding the way international new ventures actively choose and seek presence in the foreign markets, and how it enriches the international market selection literature.

This study seeks to examine whether and how the implementation of international operations is different across companies and how this implementation affects new venture performance. By comparing each type of international expansion, I provide a detailed picture of the key events that influence international new venture performance. Financial information and international operations of the four companies are compared as below.

\section{Financial information and international operations of four companies}

\begin{tabular}{|c|c|c|c|c|c|c|c|}
\hline Firm Name & & $\mathbf{1 9 9 4}$ & $\mathbf{1 9 9 5}$ & $\mathbf{1 9 9 6}$ & $\mathbf{1 9 9 7}$ & $\mathbf{1 9 9 8}$ & $\mathbf{1 9 9 9}$ \\
\hline \multirow{3}{*}{ Verticalnet, Inc } & Sales & & 0 & 0.3 & 0.8 & 3.1 & 20.8 \\
\cline { 2 - 8 } & Net Income & & -0.2 & -0.7 & -4.8 & -13.6 & -53.5 \\
\cline { 2 - 8 } & Employees & & & & 80 & 220 & 669 \\
\hline \multirow{3}{*}{\begin{tabular}{c} 
E*Trade Group, \\
\cline { 2 - 8 }
\end{tabular}} & Sales & 10.9 & 23.4 & 53.8 & 157.6 & 285 & 662.3 \\
\cline { 2 - 8 } & Net Income & 0.8 & 2.6 & -0.8 & 13.9 & -0.7 & -54.4 \\
\hline \multirow{3}{*}{ Teligent, Inc. } & Employees & 44 & 115 & 327 & 499 & 833 & 1735 \\
\cline { 2 - 8 } & Net Income & & & -12.6 & -138.1 & -281.5 & -528.9 \\
\cline { 2 - 8 } & Employees & & & 108 & 474 & 1821 & 2882 \\
\hline
\end{tabular}




\begin{tabular}{|c|c|c|c|c|c|c|c|}
\hline & Sales & & & 0.7 & 9.5 & 21.9 & 46.8 \\
\cline { 2 - 7 } $\begin{array}{c}\text { Actuate } \\
\text { Corporation }\end{array}$ & Net Income & & & -6.1 & -7.2 & -3.2 & 3.9 \\
\cline { 2 - 8 } & Employees & & & & 114 & 149 & 287 \\
\hline
\end{tabular}

\begin{tabular}{|c|c|c|}
\hline Firm Name & $\begin{array}{l}\text { Post-IPO Revenue } \\
\text { Growth }\end{array}$ & Internationalization \\
\hline $\begin{array}{l}\text { Verticalnet, } \\
\text { Inc }\end{array}$ & $\begin{array}{l}\text { 2000: } \$-145,794 \\
\text { 2001: } \$-670,197 \\
2002: \$-30,859 \\
\text { 2003: } \$-11,015\end{array}$ & $\begin{array}{l}\text { International Exploitation: no pre-IPO international with small } \\
\text { scope of international expansions } \\
\text { "We intend to market our products and services to international } \\
\text { markets directly over the Internet, as well as through resellers and } \\
\text { affiliate relationships." }\end{array}$ \\
\hline $\begin{array}{l}\text { E*Trade } \\
\text { Group, Inc }\end{array}$ & $\begin{array}{l}\text { 2000: } \$ 1,368,318 \\
\text { 2001: } \$ 1,275,364 \\
\text { 2002: } \$ 1,325,864 \\
\text { 2003: } \$ 1,483,708\end{array}$ & $\begin{array}{l}\text { International Exploitation: no pre-IPO international and with } \\
\text { incremental growth after IPO } \\
\text { "Although E*TRADE currently has no marketing program } \\
\text { directed specifically at consumers outside the United States, it } \\
\text { has over } 400 \text { accounts for customers with addresses in foreign } 46 \\
\text { countries who open accounts directly with the Company. The } \\
\text { Company expects its international customer base to grow with } \\
\text { the continued proliferation of the Internet and increasing free } \\
\text { trade, although there can be no assurance in that regard." }\end{array}$ \\
\hline $\begin{array}{l}\text { Teligent, } \\
\text { Inc. }\end{array}$ & Survival until 2002 & $\begin{array}{l}\text { International Exploration with pre-IPO international with further } \\
\text { large scope of international expansions }\end{array}$ \\
\hline $\begin{array}{c}\text { Actuate } \\
\text { Corporation }\end{array}$ & $\begin{array}{l}\text { 2000: } \$ 18,864 \\
\text { 2001: } \$ 25,634 \\
\text { 2002: } \$ 14,308\end{array}$ & $\begin{array}{l}\text { International Ambidexterity with pre-IPO international with } \\
\text { further incremental growth "We plan to establish an early } \\
\text { marketing, sales, and support presence in selected international } \\
\text { markets, including targeted European and Asian countries, to } \\
\text { enhance our long-term competitive advantage in these regions." } \\
\text { Post-IPO: "We currently market and sell our products through a } \\
\text { direct sales force in North America and Europe and, to a lesser } \\
\text { extent, through distributors internationally. We intend to continue } \\
\text { to expand our marketing and selling efforts through partnering } \\
\text { with third parties." }\end{array}$ \\
\hline
\end{tabular}

In the cases analyzed, I also compared how other key factors are different across the cases (including resource advantages, information availability, managerial mindset and international experiential knowledge), which were demonstrated as key constructs to develop theoretical propositions in Chapter 3. Archival data suggested that these firms could improve their technology development and provide the key competences of the firm. Prospectuses in SEC filings provided firm statements about strategy and structure at the time of their IPO announcements, and also provided forward-looking 
statements about how they predicted their further growth, addressing strategy and development of services, as well as global expansion.

\section{Importance of Technology Resources for International New Ventures:}

First, each company highlights the importance of its technology development in its Prospectus in SEC filings. Moreover, they emphasize the scale of their technology and proprietary rights. This provides evidence that resource advantages are one key factor for these international new ventures. The international exploitation company, Verticalnet, Inc , specifically emphasized the strategy of developing a broad range of technologies as their resource advantage:

"We satisfy a developing market not currently being adequately served through traditional channel, such as trade publishers, trade shows and trade associations... our vertical trade communities exploit the interactive features and global reach of the internet... our objective is to continue to be the largest creator, owner and operator of a portfolio of targeted business-to-business vertical trade communities and the internet.” (SEC prospectus, 1999)

"We have developed and implemented a broad array of technologies including site management, search, customer interaction and transaction processing systems using a combination of our own proprietary technologies and commercially available, licensed technologies." (SEC prospectus, 1999)

Verticalnet, Inc states: "We believe our solutions are differentiated by the breadth of our Supply Management offering, the depth of our services expertise, our strong capabilities especially in Spend Analysis and Advanced Category Sourcing and our Bid analysis Optimization functionality." (SEC prospectus, 1999)

In addition, Verticalnet, Inc also emphasized the importance of ownership of their resources: 
"Proprietary rights are important to our success and our competitive position. To protect our proprietary rights, we rely generally on copyright, trademarked, and trade secret laws..." (SEC prospectus, 1999)

"The company relied upon a combination of licenses, confidentiality agreements and other contractual covenants to establish and protect its technology and other intellectual property rights." (SEC prospectus, 1999)

The case of the other exploitation-based company, E*Trade Group, Inc, also emphasizes the importance of technology development in their growth.

"E*TRADE's objective is to leverage its leading position as a provider of electronic brokerage and information services through automation, innovation, technology, service and value. The Company's strategy to accomplish this objective includes continued aggressive marketing of its electronic brokerage services to further establish." (SEC prospectus, 1995)

"The Company's objective is to be a leader in the provision of commercial transaction processing services through automation, innovation, technology, service and value." (SEC prospectus, 1995)

The international exploration company, Teligent, Inc. , also intends to be the premier provider of high quality telecommunications services by focusing on high growth telecommunication markets. To achieve this objective, Teligent, Inc. believes that a number of factors will provide it with significant competitive advantages, including "network cost, successbased capital expenditures, speed to market and high bandwidth capability and flexibility." These factors further serve as their resource advantages. (SEC General form for registration of securities, 1997) 
Before Actuate Corporation issued its IPO, it had already stressed its specific technology competence:

“Accrue's special Navigational Graph feature provides a graphical view of path visitors take through the Web site." "Accrue's network collector technology has the differentiated ability to collect up to 50 million hits per day of Web site customer activity data from thousands of globally distributed Web sites consisting of various types of Web sites..." (SEC prospectus, 1999)

"Accure Insight is designed to provide a robust architecture for customers to implement flexible, scalable, detailed, and accurate e-business analysis. The Accrue Insight architecture is compatible with different application programming interfaces, APIs, protocols and file formats to enable integration with external systems." (SEC prospectus, 1999)

And Actuate Corporation specified that "We are a technology company. Our success depends on protecting our intellectual property asset." (SEC prospectus, 1999)

This evidence from my four case companies complements my theoretical arguments that, when new ventures grow, they are likely to recognize, understand and accept the importance of their resource advantages with strong proprietary behaviors. These firms seek market expansion in other locations, and their resource advantage is not simply based on slack resources but on the integration of different domains and specific exploitation of technological development. The higher the value of the resources and the more unique the resources are, the more likely new ventures are to choose to exploit them to gain competitive advantages in multiple locations.

\section{Importance of Information, specifically from alliances, for international new}

\section{ventures:}


Second, international new ventures rely heavily on the information availability provided by their partnerships. For the international exploitation company, Verticalnet, Inc, alliance is another key feature for understanding how important the role of information is for making international expansion decisions.

"As part of our strategy to increase the number of users that visit our vertical trade communities and to develop e-commerce activities, we actively pursue strategic alliances." (SEC prospectus, 1999)

Actuate Corporation specifically illustrated how important the role of alliance is with regard to providing information for their strategic decisions.

"Analysis of customer and preference information is critical to the success of all businesses. Analysis helps business managers make informed decisions and understand the results of those decisions. Historically, retailers knew their customers personally, enabling them to address the needs and preferences of customers...as mass media developed and businesses continued to evolve, managers became increasingly concerned with monitoring the effectiveness of distribution of information" (SEC prospectus, 1999)

"We intend to continue developing alliances with leading strategic platform providers, e-business application providers, interactive agencies...We believe that these partnership will accelerate market penetration of our software by providing additional marketing and distribution information for our applications." (SEC prospectus, 1999)

"We have also established a number of informal alliances with solution providers to supplement our information about customers as required to meet their deadlines and specifications.” (SEC prospectus, 1999) 
"To date, the Company has concentrated principally on securing alliances with online service providers...Strategic relationships with such service providers allow the Company to access a greater number of potential customers and allow the online service providers to offer their subscribers a broader range of service options." (SEC prospectus, 1999) Before E*Trade Group, Inc went international at an early stage, it already realized the importance of foreign alliances for its further expansion strategy:

“The Company plans to create "localized" user interfaces, with local languages and specialized services. The Company has been discussing possible alliances with local institutions such as brokers and banks to make portfolio management, the purchase and sales process and the transfer of funds easier for foreign investors and for foreign securities, and to ensure the Company is in compliance with local laws and regulations." (SEC prospectus, 1995)

Alliances can also negatively impact a company's exploratory international strategy, as E*Trade Group, Inc illustrates.

"One component of our strategy has been an effort to explore international markets. We have established certain joint venture and/or licensee relationships. We have limited control over the management and direction of these venture partners and/or licensees, and their action or inaction, including their failure to follow proper practices with respect to regulatory compliance and/or corporate governance, could harm our operations and/or our reputation." (SEC prospectus, 1995)

All the cases emphasized the importance of discovering new opportunities and these opportunities are embedded in their internal and external coordination system. In addition, they can also identify information from their competitive environment and their existing industry. 
Therefore, in order to achieve international operations, new ventures focus on information flow in both domestic and international markets, thus they can understand their customers' specifications in depth.

\section{Importance of Managerial Mindset for International New Ventures:}

Third, in successful new ventures, managers can improve the design of the new company and emphasize the strong competence of their firms, therefore these firms also strengthen the importance of managerial skills. And these skills include different domains. For example, Verticalnet, Inc has a founding team which includes three senior managers with diverse backgrounds. Michael J. Hagan, co-founder of Verticalnet, Inc, served at Merrill Lynch in the area of finance, technology and accounting. And another co-founder, Michael P. McNulty, held sales and sales management positions for various industry leaders.

E*Trade Group, Inc stated how important the senior group is for different activities in the company.

"The loss of the services of any of the key personnel or the inability to identify, hire, train and retain other highly qualified technical and managerial personnel, including qualified customer service personnel, in the future could have a material adverse effect on the Company's business, financial condition and operating results. Competition for such personnel is intense." (SEC prospectus, 1995)

Teligent, Inc. emphasized having an experienced management team as well and stated: “Teligent's management team, lead by Alex J. Mandl..., has significant senior management experience... this includes extensive experience in the operational, technical, sales, marketing, financial and regulatory areas." "The strain that our growth rate places upon our systems and management resources may adversely affect our business and decrease the value of your 
investment."; "We have recently experienced a period of significant expansion of our operations that have placed a significant strain on our management, administrative and operational resources.” (SEC General form for registration of securities, 1997)

This evidence complements my theoretical argument on the importance of managerial mindset. The previous experience of founding team members represents the cognitive and behavioral foundation for how managerial resources can be used to support new ventures' further growth strategy, including internationalization. And international knowledge is not simply based on whether one manager knows the market but is based on whether the founding team has a broad scope of managerial knowledge and whether some senior managers have previous educational and work experience in other countries.

For new ventures, international ambidexterity is developed through their resource advantages, information availability and managerial mindset of internationalization.

The importance of international knowledge emerged through archival data and the case review revealed important information about how certain knowledge, such as knowledge about international opportunities, will moderate the importance of resources advantages, information availability and managerial mindset. Verticalnet, Inc stated that the business experience of their management team is critical.

"To properly manage this growth, we must, among other things, implement and improve additional and existing administrative, financial and operational personnel." "Management may not be able to hire, train, retain, motivate, and manage required personnel and may not be able to successfully identify, manage and exploit existing and potential market opportunities.” (SEC Annual Report, 2001)

In addition to the diverse backgrounds of founding team members, new ventures indeed emphasize the international background of some members of their managerial teams. In their 
prospectus, Verticalnet, Inc emphasized information such as: "Mr. Wynkoop served as the Vice President of U.S. Operations for Krone GmbH, a West German telecommunications manufacturer..." One of Verticalnet, Inc's directors, Jeffrey C. Ballowe, also worked at ZiffDavis, Inc and transformed it into an international, integrated media company. The prospectus also added more information, such as: "He was responsible for establishing Ziff-Davis's European operations, managing Ziff-Davis's largest magazine group...” (SEC prospectus, 1999)

Christos M. Cotsakos joined E*Trade Group, Inc Group in 1996 as Vice President, and before joining in the company, "he held a number of senior executive positions both in the United States and Europe, including vice president and general manager for Europe, Africa and the Near East from 1988 to March 1992." (SEC Prospectus, 1993)

Previous work experience of the founders is not the only international knowledge source; which drives the internationalization of new ventures. Their educational backgrounds also matter. Actuate Corporation had Prashant K. Karnik, as their Vice President of Worldwide Client Services, who received his B.S. Degree in India. Yorgen Edhom, who was a director of Accure, received his MBA degree and MS in Engineering Physics degree in Sweden. Another director, Robert Smelick, received his degree in Australia.

In addition, international knowledge was also emphasized in building relationships with partners while international ambidextrous Actuate Corporation is pursing internationalization.

"By increasing the number of direct sales professionals as well as utilizing systems integrators and resellers to complement direct selling efforts we will be able to address a broader market beyond the domestic market for our products. As use of the Internet increases internationally, we believe that international markets will represent a significant market for our products and services.” (SEC Quarterly Report, 2003) 
Verticalnet, Inc stated the importance of accessing and acquiring new international experiential knowledge through their internationalization process:

"We have begun to shift a significant portion of our product development operations to India, which poses significant risks... we have a heightened risk exposure to changes in the economic, security, and political conditions of India. Economic and political instability, military actions, and others." (SEC Annual Report, 2002)

Actuate Corporation made specific statements in its prospectus about its international expansion strategy:

"Maintain Technological Leadership in e-Business Analysis Software. Our solutions are based on advanced proprietary technologies which provide the basis for our leading highend e-business analysis software in international market" (SEC Annual Report, 2002)

These results complement my theoretical argument about international experiential knowledge and firm international ambidexterity. Specifically, they indicate how lack of international administrative expertise will negatively influence firm growth as the strategic objective. The cross-cultural education and work experiences of some managers provide the international knowledge for the founders of the international new ventures. In addition, the relationships with customers and suppliers also provide information about the potential distribution channels for their core technology competence (Nadkarni and Perez, 2007). And the complexities of the experiential knowledge of these new ventures can interact with the mindsets of the decision-makers and subsequently reveal commitment to internationalization.

For new ventures, international ambidexterity is developed through their international experiential knowledge built at an early stage.

For new ventures, international experiential knowledge moderates the relationship between international ambidexterity and resource advantages, information availability and managerial mindset. 


\section{Conclusion and Limitations of the Case Study}

This case-based study helps in explaining how resource advantages, information availability, managerial mindset, and international experiences are associated with new ventures' internationalization. It complements the theoretical arguments I developed in Chapter 3. Furthermore, by examining firm archival data, such as Prospectuses and 10-K reports, this study provides clearer insights about the propositions regarding the drivers of international ambidexterity. These data confirm the variation in the internationalization practices observed across firms, which encourages me to generalize the results to a different set of new ventures.

First and foremost, the major limitation of this case-based analysis is that I only used archival data to do comparative analysis. This study didn't include the managers' opinions or their perceptions of their own experiences, understanding, beliefs, culture and context. Thus, although using secondary data may reduce the subjectivity of the analysis and the potential bias of respondents, one trade-off is the loss of the opportunity to develop a deep understanding of the processes involved in managerial decision making.

Second, I used public data; therefore firms may not have always reported their international operations before issuing their IPO. The use of secondary data creates challenges to understanding the early internationalization process in detail. Third, there is another question that arises, which is to what extent the proposed theoretical model can be generalized to a large sample of firms. Therefore, in the next section of this chapter, I will describe the quantitative analysis I conducted to test the hypotheses built on the theoretical concepts and frameworks proposed in Chapter 3. 
Summary of case studies of four international new ventures

\begin{tabular}{|c|c|c|c|c|c|c|c|}
\hline Firm Name & $\begin{array}{l}\text { Drive } 1 \text { Resource } \\
\text { Advantage }\end{array}$ & $\begin{array}{c}\text { Driver } 2 \text { Information } \\
\text { Availability }\end{array}$ & $\begin{array}{c}\text { Driver } \\
\text { 3Managerial } \\
\text { Mindset }\end{array}$ & $\begin{array}{c}\text { Driver } 4 \\
\text { International } \\
\text { Experiential } \\
\text { Knowledge }\end{array}$ & Drivers Summary & $\begin{array}{l}\text { Theoretical } \\
\text { Arguments }\end{array}$ & Firm Type \\
\hline $\begin{array}{l}\text { Verticalnet, } \\
\text { Inc }\end{array}$ & $\begin{array}{l}\text { Focus on Integrated } \\
\text { Knowledge Advantage } \\
\text { and Technology } \\
\text { Ownership, }\end{array}$ & $\begin{array}{l}\text { Emphasize the } \\
\text { importance of building } \\
\text { alliances }\end{array}$ & $\begin{array}{l}\text { Divers background } \\
\text { for Founding team }\end{array}$ & $\begin{array}{l}\text { International Business } \\
\text { Knowledge through } \\
\text { operation, through } \\
\text { management team. } \\
\text { Founding team } \\
\text { members have } \\
\text { international work } \\
\text { experience and } \\
\text { education experience }\end{array}$ & $\begin{array}{l}\text { + Resources } \\
\text { Advantages } \\
\\
+ \text { Information } \\
\text { Availability + Divers } \\
\text { Managerial Mindset } \\
\text { + international } \\
\text { experience }\end{array}$ & $\begin{array}{l}\text { High Level of } \\
\text { International } \\
\text { Exploitation }\end{array}$ & $\begin{array}{l}\text { Late Internationalization } \\
\text { with ownership control, } \\
\text { and closer location } \\
\text { selection as well as the } \\
\text { narrower scope of the } \\
\text { subsequent international } \\
\text { operations }\end{array}$ \\
\hline $\begin{array}{l}\text { E*Trade } \\
\text { Group, Inc }\end{array}$ & $\begin{array}{l}\text { Focus on integrated } \\
\text { knowledge advantage, } \\
\text { and aggressive } \\
\text { technology development }\end{array}$ & $\begin{array}{l}\text { Stated before IPO the } \\
\text { intension to build foreign } \\
\text { alliances for international } \\
\text { expansion, but } \\
\text { application of this } \\
\text { strategic move was too } \\
\text { difficult }\end{array}$ & $\begin{array}{l}\text { Stated specifically } \\
\text { how important the } \\
\text { senior group } \\
\text { structure is } \\
\text { important }\end{array}$ & $\begin{array}{l}\text { CEO has international } \\
\text { work experience }\end{array}$ & $\begin{array}{l}\text { + Resources } \\
\text { Advantages } \\
\text { +/ Information } \\
\text { Availability+ Divers } \\
\text { Managerial Mindset } \\
\text { + international } \\
\text { experience }\end{array}$ & $\begin{array}{l}\text { Low level of } \\
\text { International } \\
\text { exploitation }\end{array}$ & $\begin{array}{l}\text { Late Internationalization } \\
\text { with broader scope of } \\
\text { subsequent international } \\
\text { operation }\end{array}$ \\
\hline Teligent, Inc. & $\begin{array}{l}\text { Technology Company } \\
\text { with advantages in } \\
\text { different functions. } \\
\text { Domestic Knowledge } \\
\text { Ties }\end{array}$ & N/A & $\begin{array}{l}\text { Divers background } \\
\text { for Founding } \\
\text { team. Stated } \\
\text { specifically the } \\
\text { divers background } \\
\text { of CEO }\end{array}$ & $\begin{array}{l}\text { International } \\
\text { exploration but not } \\
\text { emphasized specific } \\
\text { international } \\
\text { experience }\end{array}$ & $\begin{array}{l}\text { +/-Resources } \\
\text { Advantages } \\
+ \text { + Divers Managerial } \\
\text { Mindset +/- } \\
\text { International } \\
\text { Experience }\end{array}$ & $\begin{array}{l}\text { International } \\
\text { Exploration }\end{array}$ & $\begin{array}{l}\text { Early } \\
\text { Internationalization with } \\
\text { broader scope of } \\
\text { subsequent international } \\
\text { operation }\end{array}$ \\
\hline $\begin{array}{l}\text { Actuate } \\
\text { Corporation }\end{array}$ & $\begin{array}{l}\text { Focus on Specific feature } \\
\text { of Technology } \\
\text { development and } \\
\text { emphasize the details of } \\
\text { customer needs with } \\
\text { technology ownership }\end{array}$ & $\begin{array}{l}\text { Stated continuous request } \\
\text { to build alliances for } \\
\text { technology development }\end{array}$ & $\begin{array}{l}\text { Divers background } \\
\text { for Funder team, } \\
\\
\text { Stated specifically } \\
\text { how important the } \\
\text { senior group } \\
\text { structure is } \\
\text { important }\end{array}$ & $\begin{array}{l}\text { Founding Team } \\
\text { Members with } \\
\text { different international } \\
\text { experience, firm } \\
\text { international } \\
\text { experience through } \\
\text { operation }\end{array}$ & $\begin{array}{l}\text { +Resources } \\
\text { Advantages } \\
\text { +Information } \\
\text { Availability } \\
\text { + Divers Managerial } \\
\text { Mindset }\end{array}$ & $\begin{array}{l}\text { International } \\
\text { Ambidexterity }\end{array}$ & $\begin{array}{l}\text { Early } \\
\text { Internationalization with } \\
\text { ownership control, and } \\
\text { closer location selection } \\
\text { as well as the narrower } \\
\text { scope of the subsequent } \\
\text { international operations }\end{array}$ \\
\hline
\end{tabular}

